\title{
Medische praktijkvoering en zelfevaluatie bij Belgische huisartsen en specialisten
}

Citation for published version (APA):

Prove, W. (1979). Medische praktijkvoering en zelfevaluatie bij Belgische huisartsen en specialisten. [Doctoral Thesis, Maastricht University]. Rijksuniversiteit Limburg. https://doi.org/10.26481/dis.19791214wp

Document status and date:

Published: 01/01/1979

DOI:

10.26481/dis.19791214wp

Document Version:

Publisher's PDF, also known as Version of record

\section{Please check the document version of this publication:}

- A submitted manuscript is the version of the article upon submission and before peer-review. There can be important differences between the submitted version and the official published version of record. People interested in the research are advised to contact the author for the final version of the publication, or visit the DOI to the publisher's website.

- The final author version and the galley proof are versions of the publication after peer review.

- The final published version features the final layout of the paper including the volume, issue and page numbers.

Link to publication

\footnotetext{
General rights rights.

- You may freely distribute the URL identifying the publication in the public portal. please follow below link for the End User Agreement:

www.umlib.nl/taverne-license

Take down policy

If you believe that this document breaches copyright please contact us at:

repository@maastrichtuniversity.nl

providing details and we will investigate your claim.
}

Copyright and moral rights for the publications made accessible in the public portal are retained by the authors and/or other copyright owners and it is a condition of accessing publications that users recognise and abide by the legal requirements associated with these

- Users may download and print one copy of any publication from the public portal for the purpose of private study or research.

- You may not further distribute the material or use it for any profit-making activity or commercial gain

If the publication is distributed under the terms of Article $25 \mathrm{fa}$ of the Dutch Copyright Act, indicated by the "Taverne" license above, 


\title{
MEDISCHE PRAKTIJKVOERING EN ZELFEVALUATIE BIJ BELGISCHE HUISARTSEN EN SPECIALISTEN
}

\section{PROEFSCHRIFT}

ter verkrijging van de graad van doctor in de sociale wetenschappen aan de Rijksuniversiteit van Limburg, op gezag van de Rector Magnificus Dr. W.H.F.W. WIJNEN, hoogleraar in de faculteit der geneeskunde, in het openbaar te verdedigen in de aula der universiteit op vrijdag 14 december 1979 des namiddags te $\mathbf{1 6 . 0 0}$ uur precies.

door

\author{
WALTER PROVÉ \\ geboren te Beervelde (België)
}


Promotor: Prof. Dr. H. PHILIPSEN

Referenten : Prof. Dr. W. BROUWER

Prof. Dr. J.A.A. VAN DOORN 
Aan mijn mocder en wijlsn mijn vader.

Aan Marthe en Johan 
1931.

"Er is geen vak voor hetwelk de belangstelling zoo algemeen is als de geneeskunde, omdat ze de beschermster is van het opperste wereldsche geluk..."

$$
\begin{aligned}
\text { (Or.J.LEBEER : "Over moderne geneeskunde" } \\
\text { Brussel) }
\end{aligned}
$$

$1976 \ldots$

blijkt niet iedereen er gelukkig mee dat zich bij die schare van belangstellenden, sociologen hebben gevoegd: "... vooral als het er op aan komt de werkelijke belangen te verdedigen van een welbepalde kwaliteitshuisartsengeneeskunde, schiet men schromelijk te kort of slaat men zelfs helemal de bal mis... Hoe zou het ook anders kunnen indien men zich laat verdedigen door een jurist of vooral door een socioloog".

$$
\text { CDR.E.CORNELIS - Artsenkamer Dr.WIJNEN in : }
$$

"De Standaard" 8-1-1976) 
DANK

Het is mij een oprechte vreugde allen te danken die bijgedragen hebben tot de verwezenlijking van deze studie.

Dat mijn diepe dank vooraf naar mijn onlangs overLeden Hooggeleerde Leermeester, Professor Dr. J. HAESAERT gaat, zal niemand mij ten kwade duiden. Hij is het immers die mij langs het werk van E. JACO: "Patients, physicians and Illness" dat hij mij in 1963 ten geschenke gaf met de woorden: "Op dit terrein valt nog alles te doen" in de immense wereld van de medische sociologie binnenloodste.

Dank ook voor elk college dat hij afsloot met wetenschappelijke twijfel.

Wanneer we dan in de loop der jaren gelejdelijk een eigen bibliotheek op medisch-sociologisch gebied opbouwden en na moeizaam verzamelen en verwerken van onderzoekingsmateriaal deze verhandeling kunnen voorbrengen, aanzie ik het als een grote plicht mijn diepste eerbied aan J. HAESAERT te betuigen.

Naar Professor Dr. H. PICARD, Directeur van het seminarie voor statistiek van de Rijksuniversiteit te Gent gat mijn zeer bijzondere attentie voor de enorme faciliteiten die hij mij verleende ajjo proefschrift uit te werken en te voltooien en voor zijn ktitische inbreng in de verwerking van de cijfergegevens.

Vervolgens dank ik met bijzondere gevoelens de Hooggeleerde Heer Protessor Dr. J.A.A. VAN DOORN, Hoogleraar aan de Erasmusuniversiteit te Rotterdam. Hij las met de meestebereidwilligheid en belangstelling een eersteversie van mijn proefschrift en wees mij terecht op heel wat gebreken. Dank zij hem kon ik voor verdere uitdieping steunen op de bijzonder harde, doch uiterst leerzame kritieken van mijn promotor, Professor Dr. H. PHILIPSEN, Hoogleraar aan de Medische Faculteit the Mastricht. 
De kritische distantie ten anzien van mijn werk, Warde Promotor, uw ijskoude opmerkingen en dwingende zoekopdrachten, lieten mij uw leermeesterschap naar warde schatten: "du choc des idées jaillit la lumière".

Voor dit wetenschappelijk avontuur, dat mijn uiterste inzet heeft opgeëist, ben ik U zeer erkentelijk.

Voor het gezag warmee U, Professor Dr. W. BROUWER, mijn proefschrift hebt beoordeeld, voel ik mij zeer verplicht. Professor Dr. Edw. ROSKAM, Hoogleraar aan de Katholieke Universiteit van Nijmegen ben ik diepe dank verschuldigd voor de bijzondere belangstelling warmee hij mijn onderzoekgegevens heeft onderzocht nar hun vatbaarheid voor een multidimensionele benadering.

Aan Chris BLOOS, wetenschappelijk medewerker aan het Sociologisch Instituut van de Rijksuniversiteit te Leiden, mijn innigste dank. Hij is het die, met zijn technisch-wetenschappelijke geest, zijn onverdroten ijver en eindeloos geduld alle onderzoekingsmateriaal door de leidse computer heeft gejagad. De ransuilen weten er van mee te spreken...

Aan Mevr. Yvette VAN BAVINCHOVE-OSSOLA, werkleidster bij het Seminarie voor Statistiek van de Rijksuniversiteit te Gent, die steeds ten strijde trok voor de "serieuze artsen" (die wij "technici" noemen)en nooit akkoord was met de opvattingen van de "niet-serieuze artsen" (die wij, QUERIDO indachtig, zeer warderen) diepe dank. Zij betekende nu eens met haar schertsend kritische taal, dan weer met haar bemoedigende warme woorden, voor ons steeds een echte steun.

Pierre VAN EECKHAUT, assistent aan hetzelfde seminarie, dank ik voor zijn gevatte, spirituele tussenkomsten. Voor de zorg, besteed aan dit drukwerk, dank ik oprecht de heer J.P.PATIJN, correspondent bij het seminarie voor statistiek en ook het personeel van de Centrale Bibliotheek van de Rijksuniversiteit te Gent. 
De artsen die door hun welwillend antwoord a an het welslagen van deze studie hebben meegewerkt, ben ik zeer erkentelijk.

Aan de voordracht van deze studie moet ik evenwel een duidelijk "mea culpa" hechten. Het veldonderzoek werd afgesloten in 1968. Een aantal omstandigheden, alle hier moeilijk te vernoemen, droegen in anzienlijke mate bij tot een vertraagde rapportering. Ook mijn persoonlijke strakke houding ten a anzien van een aantal statistische verwerkingsmogelijkheden, waar mijn Promotor mij terecht heeft op gewezen, noopten mij tot en grondige herziening ten goede.

Innige dank vervolgens aan mijn vrouw, die met har uiterste zin voor orde, mijn slordigheid wist op te vangen en wel en wee van het ganse onderzoek gedurende vele jaren in vak moeilijke omstandigheden heeft gedeeld.

Tenslotte denk ik aan mijn 84-jarige kommervolle, goede moeder. Voor har ben ik diep gelukkig dat zij deze gebeurtenis heeft mogen beleven. 
INHOUD

$B \backslash z$.

DANK .

DEEL I. DE RANDMEDISCHE CONTEXT VAN DE PRAKTIJKVOERING.

HOOFDSTUK I. PROLOOF.

1. Inleiding. 3

1.2. Probleemstelling. 13

1.3. Opzet van het onderzoek. $\quad 14$

1.4. Afbakening van het onderzoek. 15

1.5. De vragenlijst. 19

1.6. Het vooronderzoek. 20

1.7. Het eigenlijk onderzoek. 21

1.8. Voorbereiding van het onderzoekingsmateriaal. $\quad ? 5$

1.8.1. Diplomajaar, aantal jaren praxis, Leeftijd. 25

1.8.2. Sociale herkomst. 26

1.8.3. Het ecologisch en sociaal milieu van de praktijkvestiging. $\quad 27$

1.8.4. Aard van de medische praxis. 23

1.8.5. Het medisch specialisme. 29

HOOFDSTUK II. MAATSCHAPPELIJKE EN PSYCHOLOCISCHE ASPECTEN VAN DE PRAKTIJKVOERING.

Inleiding. $\quad 30$

2.1. Evaluatie van de genoten academische opleiding. 31

2.1.1. Beoordeling van de medische opleiding. 33

2.1 .2 . Inhoud van de kritiek. $\quad 34$

2.2. De praktijkvoering. 36 
2.2.1. 2anditedishe inormatie: routine of coselstiex? 3?

2.2.2. De paramedische infrastructur. 37

2.2.?.1. Aan wie hoort het randmedische informatie teverzamelen?

2.2.2.2. Paramedici in de private praxis. 39

a. Tewerksteling van paramedici in de $\because \forall: c:$ praxis.

b. Hei vartizen. 42

2.2.2.3. Eval dat in an de ervarem paramedische tusserkomst. 43

Samenvatting. $\quad 44$

2.2.3. Medisch teamier. 45

2.2.3.1. Evaluatie var de samenwerking. 45

2.2.3.2. Evaluat je van de gedeetde verantwoordelijkheji. 46

2.2.4. Groepspraktik of individuele oraktijk. 47

2.2.4.1. Inleiding. $\quad 47$

2.2.4.2. Resultaten van he: onderzok.-

De voorkeurshouding. 49

HOOFDSTUK III. OORDELEN OVER DE SOCIAAL-PSYCHOLOGISCHE ACHTERGRONDEN EN DE PREVENTIE IN DE PRAKTIJKVOERING.

Inleiding.

3.1. Specialisatie en sociad-osycholoaische context van de praxis.

3.2. Waardering van het preventief element -

3.2.1. Houding van de arts ten a anien van een a antal geinstitutionaliseerde medischpreventieve voorzieningen.

3.2.2. Waardering van het preventief element in eigen praxis. Zel fevaluatie. 
3.3. Wardering van het curatief element in de praxis.

3.4. Specialisatie en verantwoordelijkheid van de huisarts.

DEEL II. DE ZELFEVALUATIE VAN DE ARTS.

HOOFDSTUK IV. ZELFEVALUATIE VAN DE ARTS IN EEN AANTAL ROL COMPONENTEN.

4.1. Inleiding. 71

4.2. De factoranalyse. 74

4.3. De sociaal-integratieve rollcomponent. 75

4.3.1. Inleiding. 75

4.3.?. Resultaten van het onderzoek. 77

4.4. De informatieve rolcomponent. 79

4.4.1. Inleiding. 79

4.4.2. Resultaten van het onderzoek. 82

4.5. De social-opvoedende rolcomponent. 88

4.5.1. Inleiding. 88

4.5.2. Resultaten van het onderzoek.

4.6. De psycho-therapeutische/'magische' rolcomponent.

4.6.1. Inleiding. 96

4.6.2. Resultaten van het onderzoek. 100 4.7. Samenvatting.

HOOFDSTUK V. SYNTHESE.

Inleiding.

108

5.1. Invloed van achtergrondvariabelen op opinies, at titudes en evaluaties. 
5.1.2. Specialisne en leeftijd als verklarende factoren voor een antal afzonderlijke attitudes en evaluaties.

1. Het rout inematig betrekken van veel/weinig randmedische informatie in de praxis.

2. Voorkeur voor de individuele of voor de groepspraktijk.

3. Ondanks het toenemend aantal specialisten, blijft de verantwoordelijkheid van de huisarts over een langere termijn bestaan.

4. Helpen/genezen is de belangrijkste opdracht van de arts.

5. Identificeren zich zeer duidelijk/ slechts zwak in de informatieve rolcomponent.

6. Verklaren dat de academische opleiding die zij genoten, adequatl niet adequat is geweest.

7. Verklaren gunstige ervaring/geen dergelijke ervaring te hebben met het optreden van hulpkrachten in eigen praxis.

8. In de academische opleiding moet het accent op de algemeen medische vorming/op specialisatie worden gelegd en in de praxis moet de psy- cho-sociale context (niet) worden betrokken.

5.2. Multidimensionele verklaring.

5.2.1. Inleiding.

5.2.2. Opzet van de resultaten der analyse.

5.2.3. De drie dimensies. 
1. Eerste dimensie : individualistische hulpverlening.

a. Omschrijuing en benoeming. 123

b. Rangorde. 124

2. Tweede dimensie: integrale geneeskunde. 128

a. Omschrijuing en benoeming. $\quad 128$

b. Rangorde. 129

3. Derde dimensie : wardering van gekwali-

ficeerde hulpkrachten. $\quad 132$

a. Omschrijuing en benoeming. 132

b. Rangorde. 133

5.2.4. Interdimensionele rangorde. 137

5.2.5. Schematische voorstelling van de totalstructuur per specialisme naar leeftijdscategorie.

5.3. Beknopt overzicht van de poging tot profilering.

NOTEN.

Appendix I : Statistische verwerking
Appendix I : Significante relaties met het beoefend specialisme

Appendix III: Frequentietabellen: significante relaties

Appendix IV : Geroteerde factormatrix

Appendix V.1: Stapsgewijze meervoudige 
Appendix V.2.:Standaardscores 207

Appendix VI. $1:$ Lijst der afhankelijke variabelen,betrokken in de multidimensionele schalanalyse 216

Appendix VI.2: Eindconfiguratie(MINISSA-I (N)) 218

Appendix VI. $3:$ Frequentieverdeling van de scores der artsen per dimensie 219

Appendix VI.4.1.: Te Dimensie(samenstelling) 220

Appendix VI.4.2.: 2e Dimensie(samenstelling) 221

Appendix VI.4.3.: 3 e Dimensie(samenstelling) 222

Appendix VI.4.4.: Scores en rang der onderscheiden specialismen in de dimensies 
DEEL I

DE RANDMEDISCHE CONTEXT VAN DE PRAKTIJKVOERING. 

HOOFDSTUK 1. PROLOOG.

1.1. INLEIDING.

De latste vier à vijf decennia is de ontwikkeling van de medische kennis de weg ingeslagen van een streng wetenschappelijke benadering van ziekteverschijnselen.

Met het oog op een betere medische zorg, werd het accent gelegd op een meer rationele therapie, die evenwel a an bepaalde kwalitatieve eigenschappen heeft ingeboet. Immers de arts die zich in zijn vak zo competent mogelijk wenste te houden, zag zich verplicht tot de keuze van één specifiek terrein, warin hij een grondige kennis poogde te verwerven. Dergelijke beperkingen leiden niet enkel tot specialisatie in de praxis, mar ook tot een specialisatie in de opleidina. Daardoor werd het doel van de medische zorg $\mathrm{nl}$. de zieke, verdrongen door de a andacht naar de grondige kennis van een deel van de medische wetenschap m.a.w. het specialisme als medisch-technisch middel.

zieken zijn echter niet enkel objecten van medischtechnische betekenis. Een verbijzondering van de wetenschappelijke kennis en van de intellectuele belangstelling voor onderzoek van het detail, kan ten koste gaan van enige aandacht voor de social-culturele en soctal-psychologische ongeving van de mens.

Dit betekent geenszins dat de arts ook in deze bevoegdzou zijn. Dit is onmogelijk. Wel dient gesteld te worden dat hij zowel in zijn gedragingen als in zijn instelling t.o.v. de patiènt en diens aandoening deze wetenschappelijke context op zijn minst weet te warderen.

Het specialisatieproces bood echter, zoals hierboven reeds vermeld, geen vruchtbare bodem aan de beoefenaren van de medische praktijk om zich deze kwaliteiten te kunnen toeeigenen. Dit is te verklaren uit de onderscheiden fasen die de specialisatie heeft doorgemakt. 
"Cela ne présente aucun inconvénient quand le spécialiste possède une culture médicale générale, quand il n'est pas borné a sa branche et qu'il en connait les limites. Toutefois, il est clair qu'un medecin n'ayant toute sa vie, sous les yeux qu*un groupe étroitement limité de maladies, court le danger de devenir exclusif, de ne tendre à soigner que son organe spécialisé et à ne pas toujours accorder une attention suffisante a lhome souffrant, qu'est la malade". (SIGERIST, H.E., 1932).

Om technische topprestaties op specialistisch gebied te bereiken, blijft verdere specialisatie dus hoogst geboden. maar dan moet ze worden opgebouwd op een reeds voorheen verworven, bepald voldoende brede kennis op algemeen medisch gebied.

De hooggespecialiseerde arts mag echter slechts optreden, nà een grondig algemeen medisch onderzoek van de patient, waruit blijkt dat specialistisch optreden wenselijk is.

Bepalde rechtvaardigingen en motiveringen pleiten ten gunste van de specialisatie, dus betere (technische) zorg voor de patient, grotere bedravenheid van de arts, precies klinisch-biologisch onderzoek, enz... Toch kunnen deze afzonderlijke oogmerken, hoe perfect ze ook worden nagestreefd en bereikt, moeilijk tot één geheel worden samengesmeed. "Durch eine Sammlung von einzelnen Laboratoriumsdaten kann niemals die Schöpferische Aufgabe einer individuellen Beurteilung des einzelnen Kranken Mensch ersetzt werden". (HOFF, F., 1954 ).

Diagnose en behandeling van de patiënt als totale persoon eisen nu wel valk de deelname van gespecialiseerde artsen, doch deze activiteiten moeten gecoördineerd en geintegreerd worden, wil de patiët er baat bij vinden. Immers, de analyse van de onderscheiden problemen die bij de ziekte van een patiënt kunnen opdagen, kan zodanig fragmentarisch zijn, dat het moeilijk wordt de resultaten ervan opnieuw samen 
te stellen (ROBINSON,G.C.,1939). In medische middens is men zich hiervan bewust.

"Hier besteht durchaus die Gefähr, dass die wirkliche Beherrschung mit dem technische fortschritt nicht schritt halt und dass wir Arzte die neven Methoden nicht souverän in unseren Dienst nehmen, sondern dass diese technischen fortschritte uns in den pienst nehmen. Was wir meinen, wird wohl sogleich verständich, wenn wir von der Gefahr der Technisierung der Medizin, von einer Fliessband Medizin sprechen, bei der zahlreiche technische Methoden mechanisch und gedankenlos nacheinander angewandt werden, ohne dass zunächst der Kranke Mensch in seiner leib-seelichen Einheit wirklich erfasst wird..." (HOFF, F.,1954).

Het groeiend probleem, veroorzaakt door de steeds verder uitdijende specialisatie kan dan teruggeleid worden tot:

- een aantasting van de traditionele persoonlijke verhoudingen die uit het continue contact tussen arts en patiënt zijn gegroeid en

- tot het fragmentarisch onderzoeken en behandelen van de patiënt in de samenstellende delen, war elk specialisme haar enig object van maakt.

In 1922 stelde L.F.BARKER reeds een balans op van de voor- en nadelen van specialisatie die nu nog steeds blijken te gelden. De voordelen betreffen vooral de technische en louter curatieve facetten van de medische praxis : verhoging van de produktiviteit, grotere bedrevenheid en nauwkeurigheid in de interventie van de arts, betere distributie van de taken, doelmatigheid op het gebied van de medische uitrusting. De nadelen liggen op het menselijk en sociaal vlak : patienten zoeken vaak specialisten die ze niet nodig hebben (lekendiagnose), falen in het streven naar voldoening in de samenwerking tussen huisarts en specialist lbvb. generatie- en karakterverschillen), engheid en monotonie van de specialistische praxis, die eerder op stukwerk gat gelijken, zelfoverschat- 
ting van de specialist.

OOK SIGERIST (1932) benadrukt de gevaarlijke h. .i-

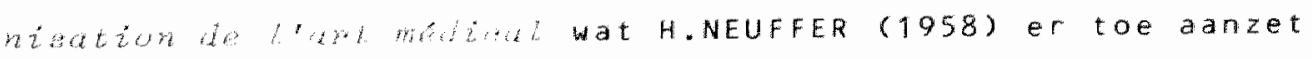
te verklaren:

"Wenn der Facharzt sich nur für sein Fach interessiert, so wird es ihm immer schwerer fallen, hinter den speziellen Krankheitserscheinungen die Krankheit auch als ein subjektieve Erlebnis des Patienten zu würdigen".

Indien de steeds verder doorgedreven specialisatie absoluut noodzakelijk is, dan is het even noodzakelijk dat de tekortkomingen ervan moeten worden verholpen...

"en donnant á tout étudiant en médecine, sans tenir compte de ce que sera sa branche future, une formation médicale générale aussi profonde et aussi universelle que possible" (SIGERIST, H.E., 1932).

De inzet van de onderscheiden specialistische interventies zal eerst dan volwaardig aan de absolute noodzaak van een benadering van de patiënt als gehele persoon beantwoorden.

Het alternatief door W.M.JOHNSON (1950) vermeld, dat de nadelen van de specialisatie kunnen omzeild worden indien de specialist eerst als algemeen geneeskundige zou starten en gradueel in zijn specialisme opgroeit, hebben we in ons onderzoek ontmoet. Is het a antal specialisten dat in dit geval verkeert evenwel klein, dan toch menen we de warde van deze eerder toevallige sequentie te moeten onderstrepen.

Een feit staat op het huidig ogenblik vast. Het special usatieproces is lang niet voltooid en zal nag veel verder reiken.

bit menen we te kunnen concluderen uit de evolutie van het antal artsen-specialist in België. Coe cijfers in tabel 1 zijn het resultat van eigen tellingen daar officiele statistieken niet beschikbaar zijn). 
Een eerste vaststelling is dat, in een tijdsverloop van amper negen jaar, het aantal specialisten met $41 \%$ steeg. Enkele voorbeelden volstaan: het antal klinische biologen steeg in deze periode met $68 \%$; de internisten dikten an met $63 \%$, de neuropsychiaters met $98 \%$ en de radio-radiumtherapeuten zijn meer dan verdriedubbeld.

Tabel 1. Aantal specialisten in 1966 en 1974.

\begin{tabular}{|c|c|c|c|}
\hline \multirow[b]{2}{*}{ Specialisme } & \multicolumn{2}{|c|}{ Aantal specialisten } & \multirow{2}{*}{$\begin{array}{l}\text { Procentuele } \\
\text { stijging }\end{array}$} \\
\hline & 1966 & 1974 & \\
\hline $\begin{array}{l}\text { Anesthesisten } \\
\text { KLinische biologen (1) } \\
\text { Cardiologen } \\
\text { Chirurgen } \\
\text { Huidspecialisten en spe- } \\
\text { cialisten in geslachts- } \\
\text { ziekten } \\
\text { Mag- en darmspecialisten } \\
\text { Gynaecologen en obstr. } \\
\text { Internisten } \\
\text { Neuropsychiaters } \\
\text { Oogartsen } \\
\text { Orthopedisten } \\
\text { Keel- neus- en oorspec. } \\
\text { Kinderartsen } \\
\text { Eysiotherapeuten (1) } \\
\text { Longartsen } \\
\text { Rötgenspecialisten } \\
\text { Reumatologen } \\
\text { Mondartsen } \\
\text { Urologen } \\
\text { Radio-radiumtherapeuten }\end{array}$ & $\begin{array}{r}184 \\
90 \\
388 \\
553 \\
333 \\
368 \\
140 \\
252 \\
478 \\
230 \\
152 \\
420 \\
19 \\
250 \\
73 \\
38\end{array}$ & $\begin{array}{r}249 \\
90 \\
564 \\
901 \\
659 \\
494 \\
208 \\
309 \\
682 \\
267 \\
164 \\
488 \\
30 \\
258 \\
116 \\
121\end{array}$ & $\begin{array}{r}35.5 \\
0.0 \\
45.4 \\
62.9 \\
97.9 \\
34.2 \\
48.6 \\
22.6 \\
42.7 \\
16.1 \\
7.9 \\
16.2 \\
57.9 \\
3.2 \\
58.9 \\
218.4\end{array}$ \\
\hline Totaal & 5536 & 7802 & 40.9 \\
\hline
\end{tabular}

Een vergelijking met nederlandse statistieken is mogilijk rechtstreeks door te voeren daar voor Nederland officięle cijfergegevens per specialisme ter beschikking staan; ook de terminologie van de specialismen wijkt vaak af van de belgische. 
Het gegeven was echter voldoende belangrijk om toch een poging tot vergelijking te wagen. Er dient echter rekening te worden gehouden met volgende beperkingen:

- slechts die specialismen die onder een identieke benaming voorkomen en die vermoedelijk hetzelfde specialisme aanduiden, worden in onderstaande tabel opgenomen; daarom wordt ook niet getotaliseerd.

- de vergelijkingsperiode voor Nederland loopt aver 6 jaar (1968 tot 1973), voor België over 9 jaar (19661974).

Tabel 2. Aantal specialisten in Nederland in 1968 en 1973.

\begin{tabular}{|c|c|c|c|}
\hline \multirow[b]{2}{*}{ specialisme } & \multicolumn{2}{|c|}{ Aantal specialisten } & \multirow{2}{*}{$\begin{array}{r}\text { Procentuele } \\
\text { stijging }\end{array}$} \\
\hline & 1968 & 1973 & \\
\hline Anesthesisten & 254 & 355 & 39.8 \\
\hline Cardiologen & 124 & 159 & 28.2 \\
\hline Chirurgen $(+p$ lastische & & & \\
\hline en neura-chirurgie) & 576 & 673 & 16.8 \\
\hline $\begin{array}{l}\text { Huidspecialisten en spe- } \\
\text { cialisten in geslachts- }\end{array}$ & & & \\
\hline $\begin{array}{l}\text { clacisten in gestachts- } \\
\text { ziekten }\end{array}$ & 213 & 229 & 7.5 \\
\hline Mag- en darmspecialisten & 24 & 20 & - \\
\hline Synaecologen-ver losk. & 304 & 373 & 22.7 \\
\hline Internisten & 720 & 893 & 24.0 \\
\hline Neurologentpsychiaters & 932 & 1075 & 15.3 \\
\hline oogheelkundigen & 256 & 313 & 22.2 \\
\hline Orthopedisten & 126 & 151 & 19.8 \\
\hline Keel-,rieus- en oorspec. & 247 & 290 & 17.4 \\
\hline Kinderartsen & 353 & 424 & 20.1 \\
\hline Revalidatie en fysioth. & 68 & 94 & .38 .2 \\
\hline Longartsen (t tuberculose) & 269 & 286 & 6.3 \\
\hline Reumatologen & 51 & 57 & 11.8 \\
\hline Urologen & 66 & 100 & 51.5 \\
\hline
\end{tabular}

Nederland en belgié:

Vooraf nog volgende algemene vergelijking tussen

Total aantal specialisten Nederland

$1968: 5113$

$1973: 6110 \%$ stiging: 19.8

Be Lgi ë

$1966: 5536$

$1974: 7802 \%$ stijging:

40.9 
In 1966 waren er in België reeds duidelijk meer specialisten dan in 1968 in Nederland. Hier kunnen zow andere opleidingsprogramm's, een andere onderwijsstructuur, als de vrije toegang tot het specialisme deze situatie in de hand hebben gewerkt.

Uit de tabelien 1 en 2 lezen we af dat, zo we aannemen dat de benaming van de specialismen in beide landen dezelfde inhoud dekt, slechts voor vijf specialismen de cijfers voor Nederland in 1968, die van België in 1966 overtreffen. Opvallend is wel het groot aantal neuropsychiaters in Nederland (in 1963 bijna het dubbele van het a antal in 1966 voor België) warvoor de stijging over de beschouwde periode van 6 jaar niet zo sterk is. Een vertraagde groei is de laatste jaren wel vast te stellen. Hiertegenover stat de uiterst sterke stijging van het antal neuropsychiaters in Belgie, war blijkbaar een achterstand moest worden ingehaald.

opmerkelijk sterk is ook de groei van het antal cardiologen, oogartsen, anesthesisten, internisten, fysiotherapeuten en urologen in Nederland, specialismen die, behoudens de eerste twee vernoemde, ook in België een gevoelig accres vertonen.

De pneumologen (longartsen) kennen in beide landen de kleinste groei.

Tenslotte wijzen we op de gastro-enterologie. Dit specialisme bestaat blijkbaar in beide landen enkel nog bij naam. Vermoedelijk staan we hier voor een verschijnsel van overspecialisatie wardoor het werkterrein van de internist overmatig werd ingekrompen. Het 'opnieuw, inlijven van deze specialisten bij de inwendige geneeskunde, verklaart dan ook de duidelijke angroei in dit specialisme:

In zover de cijfers vergelijkbaar zijn, treden verder geen noemenswardige gelijkenissen meer op. 
De artsen worden er echter niet doelgericht voor opgeleid. Hoogstens bezitten sommigen een feeling; de meesten moeten die vardigheid verwerven langs de difficut tong-run way van de professionalisering.

1.2. Probleemstelling.

Op grond van voorgaande overwegingen en vaststellingen zijn we geneigd te verklaren dat de specialist in België de gezinsarts is komen verdringen.

Immers, de gezinsarts die voorheen alle leden van een gezin behandelde, bestaat nog nauwelijks. De kinderarts behandelt de kinderen, de ouderen gaan, zelfs voor een gewoon ongemak, rechtstreeks naar de internist.

Het fragmentarisch benaderen van de individuele patiënt is voltrokken, waardoor de continuiteit van een begrijpende medische zorg wordt belemmerd, zo niet onmogelijk gemakt. De uiterst technische bekwamheden warmee de onderscheiden specialisten de patiënt benaderen, vormen een hinderpal voor een begrijpende houding t.o.v. de patiënt als gehele le persoon. Het organisme van de patiënt staat primair, zijn matschappelijke essentie secundair.

Het gevar schuilt echter niet enkel in de specialisatie op zichzelf, mar moet ook worden geplatst in de uitbouw van het systeem van de medische zorg.

Hierboven wezen we reeds op de stugheid van sommige huisartsen inzake verwijzing. Maar anderzijds - en dit sprujt voort uit de heersende situatie te lande - kan elke patiënt zich rechtstreeks tot om het even welke specialist wenden, $z i j$ deze nu al dan niet de gepaste man. In Nederland kan, behoudens voor de oogarts, de patiënt enkel via de huisarts bij de specialist terecht. 
Ons systeem houdt aldus twee risico's in:

- de patient wordt door de vrije bereikbaarheíd van de specialist a angezet zijn eigen diagnose te stellen en poogt dan de gepaste specialist uit te kiezen, warbij aangepaste medische zorg vaak wordt uitgesteld;

- de a angezochte specialist ziet enkel zijn onderzoeksgebied wardoor de patient gelooft dat verder alles in orde is.

Meteen dringt zich hjer een kapitale vraag op.

Tot welke graad van specialisatie mag worden opgeklommen om de vervreemding van de patient als matschappelijk wezen te voorkomen? We nemen immers a an dat niet alle specialisatie per se naar isolement van de patiént leidt, maar dat, tussen de specialistische gebieden in dit opzicht verschillen bestaan.

Specialistische kundigheden kunnen immers zeer gearticuleerd of zeer technisch zijn, terwijl andere per definitie de matschappelijke ongeving van de patientent niet kunnen negeren. Noemen we hier bij wijze van voorbeeld de kindergeneeskunde, war ook mede de moeder patiente kan zijn of de psychiatrie warin matschappelijke en psychische factoren onlosmakelijk met de ziekte zijn verweven.

Elk specialisme vertoont enkele karakteristieken warin het $z$ ich in dit opzicht onderscheidt van een ander specialisme.

In deze problematiek pogen we in onderhavige studie enige klarheid te brengen.

1.3. Opzet van het onderzoek.

Het professionaliseringsproces mag echter niet uitsluitend in de hiervoor vermelde enge begrenzing worden gezien. Rekening moet worden gehouden met de opeenvolgende fasen die naar de status van praktizerende arts hebben geleid. 
Onmiddellijke omgevingsfactoren (opvoeding, sociaal milieu, maar ook de zogenaamde roeping) kunnen de keuze tot het artsenberoep helpen meebepalen. Immers, een roeping, een prestigegevoel (waardering van anderen), gevoel voor erkenning, enz. of personen (vader-arts, huisarts, leraar, enz.) én/of gebeurtenissen (eigen ziekte, ziekte van anderen, oorlogsomstandigheden, enz.) kunnen het individueel gedrag een stuwend karakter geven in de richting van een toekomstige bestemming. Uiteraard is dit streven een hoogst subjectieve aangelegenheid met sterk sociale inslag omdat de oorsprong ervan in sociale groepen te platsen is.

Vanuit dit standpunt valt aan het begripiprofessionalisering dan de ruime betekenis van een totaal proces toe te kennen, dat ergens in de tijd anvangt, zonder dat de grenzen ervan kunnen worden vastgelegd (3).

Een passieve aanloop tot de professionalisering kan de academische opleiding worden genoemd. In deze fase wordt immers aan de toekomstige arts niet enkel de basiskennis bijgebracht, maar wordt bovendien, vaak niet-intentioneel, langs een stel van relatiepatronen in de opleiding om, aan de informele socialisatie van het beroep richting geven.

Dan volgt het ogenblik warop de status van praktizerende arts wordt bereikt. De relatiepatronen met collega's, met advizerend, verzorgend en verplegend personeel of diensten en met patiënten krijgen een andere inhoud.

Genoemde situaties in de opeenvolgende fasen der statussequentie hebben immers in mindere of meerdere mate, hun stempel gedrukt op het profesionaliseringsproces. De beoefenaren hebben in de loop van deze ontwikkeling een onoverzichtelijk en uiterst gedifferentieerd aantal sociale relaties met personen en groepen. Ook zijn zij betrokken in een even gevarieerd aantal situaties, die alle referentie- 
punten kunnen zijn voor het tot stand komen van karakteristieke attitudes en gedragingen. Hierin stat het contact met pattënten witeraard dan toch centraal.

Tijdens dit proces en binnen de beperkte rolomachroujuing van de arts-patiênt relatie ontwikkelt zich als reflectie op de rolverwachtingen van anderen (de patiënt) een professionele zelfevaluatie. In het relatiepatroon met een andere status (dan die der patiênten) houdt de professionele zelfevaluatie echter andere karakteristieken in en wordt $z i j$ met andere matstaven gemeten (4).

Deze zelfevaluatie is geen vaststaande grootheid mar moet, uit hoofde van de continu wisselende problematiek in het artsenberoep, als een dynamische kwaliteit worden gezien.

In alle voornoemde fasen van het professionaliseringsproces treden sociologische en sociaal-psychologische factoren op die a an praxis en praxisconceptie een disparaat karakter geven.

In ons onderzoek pogen we die invloeden na te gaan. Naast een par persoonskenmerken zoals leeftijd, diplomajaar, aantal jaren praxis en sociale herkomst, wordt rekening gehouden met de aard van de praxis (privat of verbonden a an en medische instelling, specialistisch of niet) en met het ecologisch en sociaal milieu van de praktijk.

De betekenis van deze items voor ons onderzoek wordt onder de titel "Voorbereiding van het onderzoekingsmaterial" nader toegelicht (1.8. van de Proloog).

In hoofdstuk 2 worden de matschappelijke en psychologische aspecten van de praktijkvoering ontleed. Vooraf wordt echter in $\dot{2} .1$. aandacht besteed a de evaluatie die de artsen toemeten aan de genoten academische opleiding. Immers in deze fase werden zij voor het eerst formeel geconfronteerd met de 
medische wereld en hun kritieken terzake zijn, zoals zal blijken, een nuttige additieve parameter van hun attitudes en rolconcepties op sociaal-psychologisch vlak van de praktijkvoering.

Wanneer de status van praktizerende arts wordt bereikt, spreidt zich een brede waier open van op de praxis betrokken problemen en relatiepatronen.

onder 2.2. wordt eerst een antwoord gegeven op de vraag of en in welke mate de artsen aan randmedische informatie een routinekarakter hechten. Onder randmedische informatie verstaan we dus inlichtingen over de psycho-sociale werkelijkheid van de individuele patiënt. Aansluitend wordt hierbij nagegaan wie volgens de artsen het best deze informatie inwint, terwijl in dezelfde gedachtengang wordt onderzocht welke de aard is van de contacten die zij met paramedische hulpkrachten onderhouden en hoe $z i j$ deze hulp weten te warderen.

Sociale identificatie binnen de beroepsgroep is eveneens een parameter voor de instelling van de arts op het sociaal-psychologisch vlak van de praktijkvoering. Nagegaan wordt welke wardering de artsen opbrengen voor de formele samenwerking in een medisch team. Vervolgens wordt het recent, doch moeizaam doorbreken van het verschijnsel van de groepspraxis belicht en nagegaan hoe de artsen hun voorkeurshouding voor individuele of voor groepspraxis verantwoorden.

Hoofdstuk 3 brengt een diepere benadering van de socio-psychologische context van de praxis. De artsen evalueren deze problematiek in het licht van het specialisatieproces (3.1.). Bijzondere aandacht krijgt de zelfwardering van het preventief element in de praxis $(3.2$.$) , terwijl ook het$ belang van'het louter curatief element wordt geevalueerd (3.3.) steeds in het raam van de toenemende specialisatie wordt tenslotte in 3.4. de vraag beantwoord in hoeverre de artsen de 
mening zijn toegedaan dat de verantwoordelijkheid van de huisarts, ingevolge het toenemend aantal specialisten, aan een verachratingsprocea onderhevig is.

overtuigd dat niet enkel technische vervolmaking garant is voor een goede geneeskunde, brengt hoofdstuk 4 de resultaten van en onderzoek naar de zelfevaluatie van de artsen in een aantal rolcomponenten. De vraagstelling werd gericht nar een antal middelen die door de arts in het werk kunnen worden gesteld om de arts-patiënt relatie zo optimaal mogelijk te verwezenlijken. Die middelen kunnen we als min of meer constante, daarom niet steeds door de arts onderkende wakingen zien, die door hem kunnen worden a angewend ter vervulling van zijn rol (en ter beantwoording a an een sociale behoefte).

Zij vormen een aantal rolcomponenten warin de arts zichzelf evalueert in functie van zijn specialisme.

Van 4.1. tot en met 4.4. warden achtereenvolgens behandeld : de sociaal integratieve rolcomponent, de informatieve rolcomponent, de sociaal-opvoedende rolcomponent en de psycho-therapeutischel "magische" rolcomponent.

Het latste hoofdstuk 5 is een poging tot synthese. Door middel van en multidimensionele schalanalyse wordt gezocht nar dié factoren die houdingen en zelfconceptie definteren.

1.4. Afbakening van het onderzoek.

Bij een studieobject als het onderhavige, komt de onderzoker tot de vaststelling dat een zeer groot aantal verklaringsfactoren rechtstreeks met de centrale waarden in verband kunnen worden gebracht en de opdracht daardoor een bijna onbeperkte draagwijdte heeft. Bovendien dringen zich in een continue stroom nieuwe cultuurelementen op, die in wisselend tempo an een sociaal verschijnsel het karakter ontnemen van duurzamheid of stablliteit. Zo hebben de ontwikkeling van de matechappelijke voorzieningen voor de geneeskundige ver- 
zorging, de opkomst en de ontwikkeling van ziekenfondsen, de voortschrijdende overheidsbemoeingen in de ziekenzorg, enz. alle in sterke mate invloed gehad op de structuur van het artsenberoep. Toch kent de beroepsultoefening en zekere stabiliteit. De beroepsethiek en de beroepscode houden immers in principe de centrale warden in evenwicht.

Het is binnen de perken van deze relatieve duurzamheid van het artsenberoep dat ons onderzoek werd opgevat. De ononderbroken stroom der gebeurtenissen van buitenuit, hebben we als gedachtenconstructie een moment tot stilstand gebracht en weggedacht om een beter inzicht te verwerven over de praktijkvoering en over de zelfconceptie van de arts met betrekking tot zijn relatie met de patient.

1.5. De vragenlijst.

De a angewende onderzoekstechniek is die van de schriftelijke vragenlijst. Zij werd aan de betrokkenen per post toegestuurd.

Gezien de scharse a anwezigheid van gespecialiseerde literatuur in de belgische nationale bibliotheken was het, naarmate de theoretische studie vorderde, geboden vooral de boekwerken uit het buitenland te betrekken.

Een intense briefwisseling met de canadese socioloog 0.HALL, heeft uitzonderlijk nuttige informatie opgeleverd. Het is uit deze moeizaam betrokken literatuur dat de vragenlijst langzaam groeide.

Gezien de specifieke inzet van ons onderzoek, kon geen beroep worden gedaan op een min of meer analoge bestaande vragenlijst en is het hier gebruikte onderzoekingsinstrument persoonlijk werk geworden.

Voor het vooronderzoek werd de vragenlijst gestencild. Voor het definitief onderzoek werd ze in beide landstalen gedrukt. 
1.6. Het vooronderzoek.

Dat het rechtstreeks overstappen van theorie lzij

deze nu fundamenteel of empirisch getint) naar definitief onderzoek onmogelijk is, ligt voor de hand. De orienteringsfase loopt inderdaad niet enkel langs overweging en literatuurstudie, maar noopt de onderzoeker zijn opzet vooraf te toetsen. Hij doet dit aan de hand van een vooronderzoek dat enkel en alleen als werkinstrument fungeert en warvan de resultaten enkel en alleen een or iënterende functie vervullen.

Met een ruime probleemstelling voor de ogen, moet dergelijk vooronderzoek ons vanuit zeer diverse gezichtshoeken nuttige informatie kunnen verstrekken over een reeks onzekerheden, die zowel de vorm, de inhoud en de omvang van het uit te voeren onderzoek, als de a angewende hulpmiddelen conderzoekstechnieken) betreffen.

Vooreerst waren we er ons wel van bewust dat de te enquêteren populatie een beroepsgroep betrof, wier activiteiten in de regel zodanig druk zijn, dat de respons op een ruim opgevat onderzoek er zou kunnen onder lijden. Overtuigd echter dat de opzet van dergelijk onderzoek toch enige belangstelling moest kunnen wekken bij de artsen, toetsten we een uitgebreide, gestencilde vragenlijst bij 400 at random uitgetrokken artsen $(6 \%)$, geografisch (provinciaal) verspreid over het belgisch grondgebied.

Bij een inlejdend schrijuen werd vermeld dat zij proefpersonen waren en dat $z i j$ werden verzocht:

- te antwoorden op de gestelde vragen;

- de vraagstelling zelf aan hun kritiek te onderwerpen;

- de tijd mede te delen die ze besteedden an het antwoorden;

- de best geschikte periode voor het definitief onderzoek
te vermelden.

Het resultat was bevredigend. Meer dan $40 \%$ der artsen beantwoordden de vragenlijst en reageerden enthousiast op de resterende informatieve vragen. 
De tijd nodig voor het invullen van de vragenformuLieren werd door de grote meerderheid van de artsen op twee a drie uren gesitueerd. Slechts drie artsen vonden deze tijd (de vragenlijst dus) te lang, doch anderzijds kregen we frequent verzoeken tot uitbreiding. Bij het definitief opstellen hebben we onze aandacht dan niet verder meer op de omvang van het vragenformulier gericht.

Een tweede reden die ons aanzette tot het uitvoeren van deze betrekkelijk ruime proefenquête, had betrekking op een reeks moeilijk uit de literatuurstudie te identificeren intermenselijke betrekkingen, met name de a ard en de omvang van de relaties met paramedisch personeel.

za bracht het proefonderzoek ons de duidelijke noodzaak aan het licht, nader in te gaan op deze relaties en ze tevens te confronteren met een reeks variabelen. zo ook verduidelijkte het vooronderzoek ons inzicht in de wederzijdse kritische instelling van huisartsen tegenover specialisten, alsook de uitgesproken differentielle houding van beide categorieën t.a.v. de onderscheiden soorten medische hulpkrachten.

Tenslot te heeft het vooronderzoek uitgewezen dat meer franstalige artsen antwoordden dan vlaamstalige, doch verschillen in een steekproef op een aantal antwoorden traden niet op. Wel konden we vaststellen dat de franstalige artsen ook meer dan hun vlaamstalige collega's geneigd zijn nít gevraagde informatie toe te voegen of bepalde antwoorden omstandiger te omschrijuen. Deze complementaire informatie liet ons dan ook toe dankbare correcties aan bepalde vraagstellingen an te brengen.

1.7. Het eigenlijk onderzoek.

zoals blijkt uit het statistisch materiaal van de artsenspreiding over de onderscheiden officieel erkende specialismen, kennen slechts enkele onder deze en relatief beperkte of zeer beperkte bezetting. Derhalve oordeelden we het opportuun de volledige populatie van de geneesheren-specialist bij de ondervraging te betrekken. 
Zonder in het detail de tijdrovende maeilijkheden te omschrijuen warmee het opzoekingswerk naar deze totale populatie gepaard ging, vermelden we toch dat:

- op het ogenblik van het onderzoek geen enkele up-to-date bron voorhanden was omtrent het beoefend specialisme, laat staan aanvaardbaar stat ististh materiaal;

- zeer veel geneesheren in de onvolledige lijsten van de beroepsverenigingen der artsen-specialist met meerdere specialismen werden vermeld; dit gold ook voor de lijsten der officiële erkenningen van het R.I.Z.I.V. (5);

- in alle provinciale bronnen reeds jaren geleden overleden artsen fungeerden;

- de eerste uitgave van de lijsten van de officiéle erkenningen van het R.I.Z.I.V. op hun beurt een ruime reeks onvolledige en oude adressen van geneesheren vermeldden en bovendien ook een 40 -tal overleden dokters.

De meerderheid van deze moeilijkheden kregen een oplossing door:

- de secretariaten van de orde der Geneesheren schriftelijk te verzoeken om ons de meest recente correcties mee te delen of ze persoonlijk ter zetel aan te brengen;

- de artsen-specialist die met meerdere specialismen figureerden ofwel schriftelijk te verzoeken om hun hoofdspecialisme te melden op en bijgevoegd formulier, ofwel ze telefonisch om een antwoord op de gestelde vraag te verzoeken.

Op de uiteindelijk 5153 verzanden vraqenlijsten ontvingen we er 183 als onbestelbaar terug (met, niettegenstaande onze inspanningen, postvermeldingen als : overleden, adres anbekend, buitenland, enz.), zodat het a antal teruggebracht werd op 4970 vragenlijsten.

Op dit aantal ontvingen we 1397 exemplaren ingevuld terug, d.w.z. $28.1 \%$. Na controle weerhielden we 1340 geldige antwoorden. De 57 onbruikbare antwoorden betroffen: 29 bepaald onvolledig ingevulde formulieren, 16 artsen zonder praxis, 9 artsen-ambtenaren en 3 militaire dokters. 
Voor de huisartsen stelde het problesm zich anders. Gezien het grote antal enerzijds, mar vooral aezien de belangrijkheid te differentiëren naar medische richting, kon een toevallige steekproef volstaan. We hielden rekening met de geografische spreiding over het national grondgebied en trokken uit de officiële lijsten van de orde een a-selecte steekproef, na vooraf alle specialisten te hebben aangekruist. Enkel de a-selecte keuze van $10 \%$ van de populatie droeg onze aandacht weg. Immers niet enig document kon ons, behalve de woonplaats, een voor alle geneesheren gekende variabele verstrekken zoals bvb. het diplomajaar of geboortedatum die wel nuttig zou kunnen worden aangewend. Op de aldus 900 toegestuurde vragenlijsten ontvingen we er 330 (36.6\%) terug, warvan er 16 als onbruikbaar moesten worden beschouwd.

Het onderzoek heeft aldus betrekking op :

Specialisten : $\quad 1340$

Huisartsen : $\quad 314$

Totaal : $\overline{1654}$ artsen

Hier zij nog aan toegevoegd dat aan de uitvoering van dit onderzoek een intraductie voorafging bij middel van een persbericht. Dit werd opgenomen in twee tijdschriften die ten behoeve van de geneesheren worden uitgegeven. Het doel en de aard van het onderzoek werd aangekondigd en de geneesheren werden verzocht er aan mee te werken.

Tenslotte zag het verloop van de enquête er als volgt uit:

Antwoorden
Zonder rappel
Specialisten
Huisartsen rappel


De spreiding per specialisme (Tabel 3), warbij de whercomben (njet officiel erkende specialismen), die moeilijk onder één der erkende te rangschikken waren en de huisartsen niet in a anmerking komen, toont a an dat de afwijkingen ten a anzien van het universum vooral voorkomen bij de reumatologen, de radio-radiumtherapeuten en de longartsen.

De eerste twee specialismen met de grootste afwijkingen zijn de twee die het minst vertegenwoordigd zijn in de totale populatie. Gezien de centrale doelstelling is te differentiëren naar specialisme, zijn deze afwijkingen van weinig belang.

Tabel 3. Responsie nar specialisme.

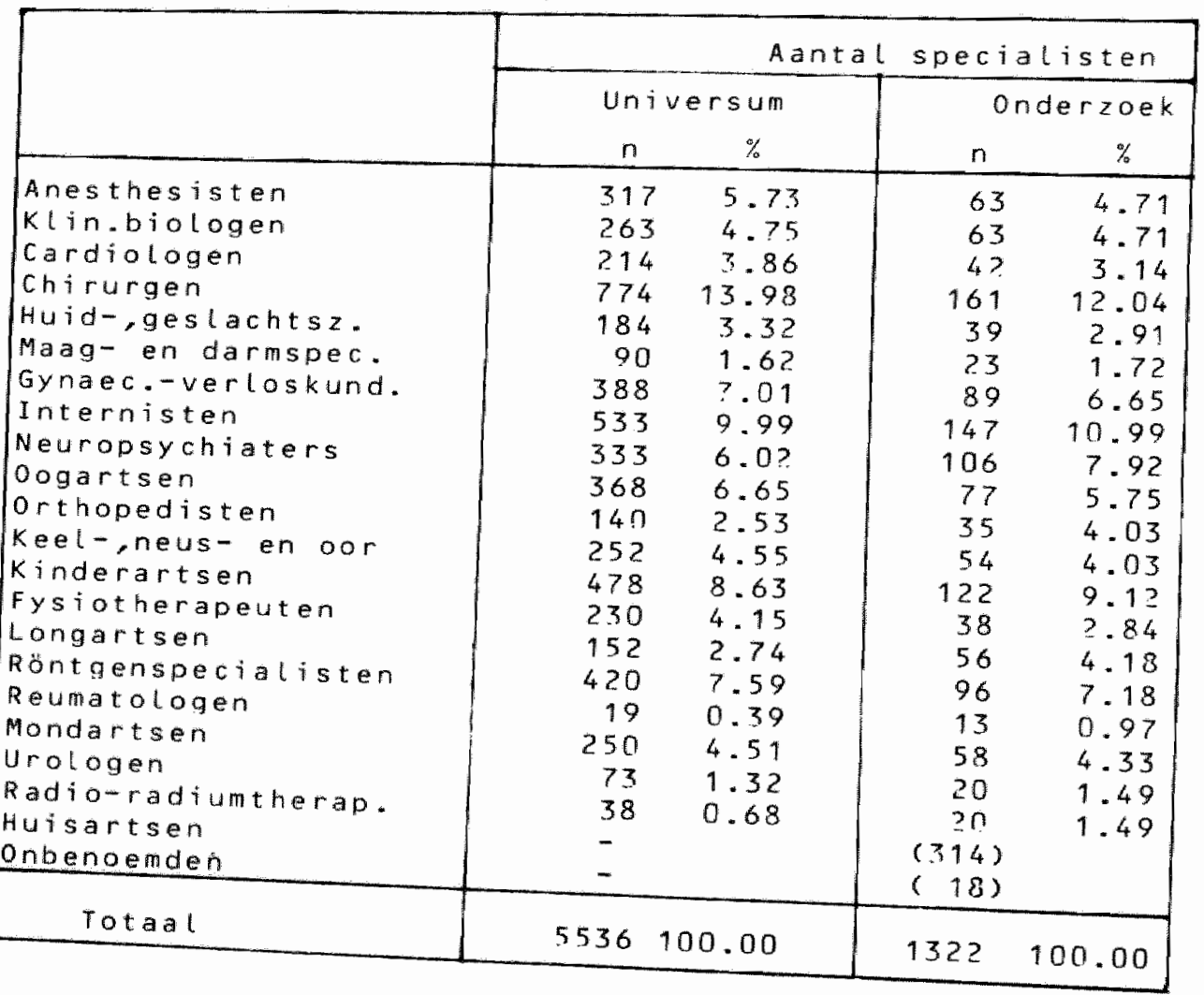


1.8. Voorbereiding van het onderzoekingsmateriaal.

Zaals hoger reeds vermeld, wordt ter analyse van de onderzoekingsresultaten gebruik gemaakt van een aantal sociologische variabelen die we weliswar niet nader onderling ontleden, mar wier betekenis voor onderhavige studie niet zonder belang is gebleken. Gezien het complementair karakter van een a antal variabelen werd, om een te gedetailleerde analyse te vermijden, overgegaan tot groeperingen wier samenstelling we hierna verantwoorden. *

1.8.1. Diplomajaar, aantal jaren praxis, leeftijd.

De drie genoemde variabelen zijn in feite onderling afhankelijke variabelen.

Tussen deze drie items bleek een nauwe samenhang te bestaan zodat zij tot éen index werden herleid, die we gemakshalve leeftijdscategorie noemen :

$\begin{array}{lcc}\text { diplomajaar } & \begin{array}{c}\text { aantal jaren } \\ \text { praxis }\end{array} & \text { leeftijd } \\ - \text { na } 1950 & 15 j & 40 j \\ -1940-1959 & 15 j & 40-50 j \\ -1940-1950 & 15-30 j & 40-50 j \\ -1940-1950 & 15-30 j & 50 j \\ - \text { vosr } 1940 & 30 j & 50 j\end{array}$

1.8.2. Sociale herkomst.

De voorwarden om tot het artsenberoep te worden toegelaten zijn niet enkelvoudig.

* Analyse en interpretatie van de onderzoeksgegevens gebeurden door middel en op grond van een aantal berekeningsmethoden. Nast de chi-kwadraattoets, worden ook de associatiematen Goodman-Kruskal's gamma en somer's t berekend. Voor samenwerkende invloeden van een a antal basisvariabelen wordt gebruik gemakt van factoranalyse, stapsgewijze meervoudige regressie en multi-dimensionele schaalanalyse (Minissa - I $(N)$ ).

( $z$ ie voor een bondige beschrijuing van deze berekeningsmethoden Appendix I). 
Het betrekken van de sociale herkomst moet in de eerste plaats gezien worden in het kader van de omvano van de te verwerven kennis om in het beroep te worden geaccepteerd. Deze kenniseis is voldoende ruim om als selectief mechanisme ongetwijfeld efficiënt te werken, teneinde het gesloten karakter van dat beroep zo goed mogelijk in stand te houden. Eens toegelaten tot de groep, is deze bovendien door een systeem van formele instituties voldoende georganiseerd om met autoriteit de beroepsethiek te vrijwaren.

Gepaard a an de vereiste kennis, is de tijdsduur warin die kennis kan verworven worden niet onbelangrijk. Het studerend gezinslid vergt op zijn minst zeven jaar financiêle inspanningen van het gezin. Deze hoge eis blijft, ondanks de democratisering van het hoger onderwijs, een niet te veronachtzamen hinderpaal.

Een andere o.j. belangrijke reden om met de sociale herkomst van de arts rekening te houden, liat bij de overweging dat het recruteren uit alle milieus de mogelijkheid in zich sluit, dat niet alle artsen zich op gelijkmatige wijze weten an te passen a an de beroepsideologie. Het proces en het tempo van de profesazunalization kan immers verschillend verlopen.

Ten behoeve van de analyse der resultaten werd gestart bij een uitgebreide beroepenclassificatie waruit een socio-professionele indeling in 13 categorieên werd opgebouwd. voor bepalde aspecten werd echter met meer beperkte classificaties gewerkt:

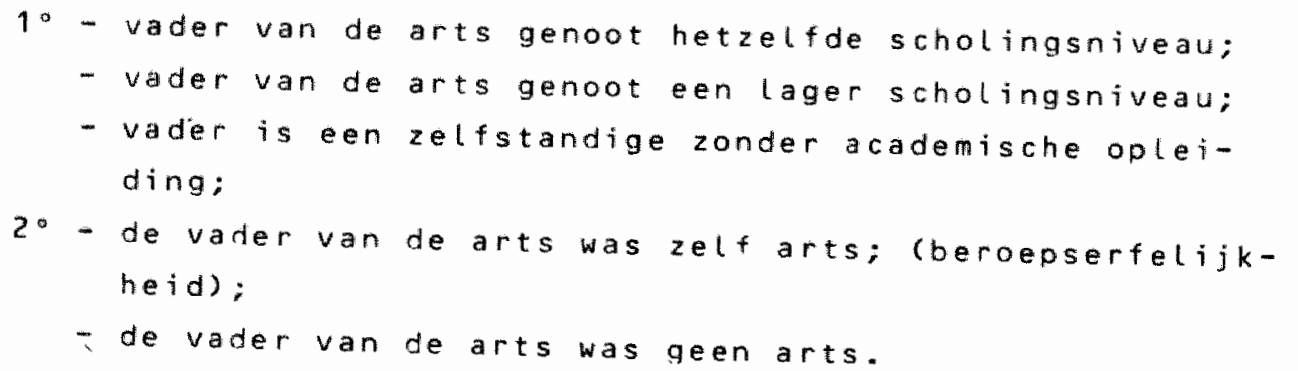


1.8.3. Het ecologisch en sociaal milieu van de praktijkvestiging.

Demografische, socio-culturele en socio-economische omstandigheden van de steden, hebben de inplanting van grote klinische instellingen noodzakelijk gemakt. De snelle ontwikkeling van hospitalisatie- en specialisatiefaciliteiten staat buiten concurrentie van de huisartsenpraxis. De specialist, mar ook de superspecialist treffen we in de grote steden aan. Enkele specialisten en huisartsen voelen zich veilig in kleinere steden en op het platteland domineert de huisarts. De specifieke, differentiërende milieus van het platteland en van de stad met hat vooralsnog niet bestudeerde sociale woongebieden, kunnen qua benadering van de patiënt aan de er gevestigde artsen sterk variërende eisen stellen. Afwisselend moet de arts zich aldus bewegen in gemeenschappen war het concept over de medische praxis in de kleine tradities van locale gemeenschappen of stadsbuurten is geqroeid of war professionele criteria en grotere integratiekans krijgen. Kortom, zowel de professionele autonomie van de arts als zijn vrijheid van handelen is de speelbal van het cultureel bepald medisch lekenconcept dat binnen eenzelfde gemeenschap een grote diversiteit vertoont. In rurale gemeenschappen war vooral de huisarts verschijnt, zal die diversiteit wellicht niet zo groot zijn, doch in stedelijke centra staan zowel de autonomie als de vrijheid van de arts in functie van het cultuurpatroon van de sociale woongebieden. Deze woongebieden, vooral in de grote stad, zijn vaak moeilijk te onderkennen. De meesten dragen een sterk heterogeen karakter, slechts enkele hebben een homogene structuur.

Waar een drieledig onderscheid tussen stad, kleine stad (25.000 inwoners) en platteland in de analyse werd betrokken, werd voor het sociaal milieu vertrokken van een zeer ruime indeling (heterogeniteit in grote steden) die echter ten behoeve van de studie tot een eenvoudige, dus bruikbare classificatie werd herleid: platteland - stad/lagere sociale 
tagen - stad/hogere sociale tagen - stad/gemengd.

1.8.4. Aard van de medische praxis.

De medische praxis is, net zoals andere beroepsactiviteiten, gevat in eer netwerk van allerlei instituties en informele betrekkingen, dje sterk kunnen variëren naargelang het praktijktype.

Twee extreme typen laten zich onderscheiden:

de private praxis en de praxis verbonden a an een instelling voor medische verzorging. In beide vormen ontwikkelt zich, vooral tijdens het professionaliseringsproces een complexe kwalitatieve verscheidenheid van wederzijise betrekkingen tussen de deelnemers wit hoofde of in functie van twee referentiesystemen:

- het eerste systeem ontwikkelt zich in een lekencultuur. Patiẻnt en arts ontmoeten elkaar in een beperkte persoonlijke relatie. In dit systeem, dat we teruguinden in de private (zelfstandige) praxis, wordt de arts in zijn optreden voor alles onderworpen aan de beourdeling clekencontrole) van de patiënt.

- het tweede is het professioneel referentiesysteem, dus dat van de medische cultuur en van de medische instellingen, waraan de arts verbonden is (ziekenhuisarts), In dit systeem wordt de arts in zijn optreden voor alles onderworpen aan de controle van collega's.

Raken weliswar in elke concrete situatie beide systemen elkaar, dan neemt dit niet weg dat opinies, attitudes en evaluaties voor de beoefenar van een van beide of van beide typen van de medische praxis kunnen verschillen. Te gelegener tijd wordt in de analyse van het onderzoek hiermee re-
kening gehowden.

1.8.5. Het medisch specialisme.

Ten einde een te grote versnippering van het cijfermaterial over de ruime reeks specialismen te voorkomen, werd nes die ook in de gaan tot enkele samenvoegingen van disciplines die ook in de praktijk het meest frequent voorkomen. 
Bepaalde specialismen werden echter uit hoofde van hun specifiek karakter dan toch geisoleerd gehouden.

op grond van een inventaris van de officiële alfabetische lijsten kwamen we tot de vaststelling dat cardiologie en preumologie (longartsen) zeer vaak worden gecumuleerd. Beide zijn specialismen met beperkte groei. De zwakke anwe$z$ igheid van de orthopedisten nodigde ook uit tot samenvoeging met de chirurgen. Chirurgen zijn trouwens het meest frequent titularus van beide disciplines. Verder wordt zowel in Nederland als in België de gastro-enterologie qua aangroei gekenmerkt door een status quo. De gebiedsafbakening van dit specialisme is onduidelijk en helt sterk over naar het zeer ruime gebied van de inwendige geneeskunde die, zoals reeds gezegd, zowel in Nederland als in België de laatste jaren meer beroepsbeoefenaren telt.

Louter op grond van het frequent samengaan in de praktijk van de oogheelkunde en het keel-, neus- en oorspeciaLisme werden ook deze twee takken in onderhavige besprekingen samengevoegd.

Vervolgens nodigde de beperkte a anwezigheid van urologen en dermato-venerologen eveneens uit tot een controle in de praktijk. Zeer frequent worden beide specialismen gecumuleerd, zodat ook hier tot samenvoegen werd overgegaan.

Tenslotte stellen we een beperkte aanwezigheid vast van de fysiotherapeuten, radio-radiumtherapeuten en reumatologen. Deze drie specialismen vertonen qua behandeling heel wat aanknopingspunten en ook in de praktijk worden deze combinaties het meest frequent aangetroffen. Een samenvoegen van deze drie richtingen lag dan ook voor de hand. 
HOOFDSTUK 2. MAATSCHAPPELIJKE EN PSYCHOLOGISCHE ASPECTEN VAN
DE PRAKTIJKVOERING.

INLEI D ING.

De gedachte dat de arts door zijn wetenschappelijke opleiding aan de universiteit, zij het nu als huisarts of als specialist, angevuld met verondersteld goed geleide stages of assistentschappen, aangevuld bovendien met zijn persoonlijke studie van allertei wetenschappelijke publicaties, het bijwonen van medische congressen of colloquia en het volgen van post-universitaire leergangen (waarbij zelden rekening wordt gehouden met de noden en wensen van de dee(nemers), in stat is de integrale geneeskunde te kunnen beoefenen, is slechts een wensbeeld. Immers, achter het wezen van deze technische vervolmaking door de natuurwetenschappelijke geneeskunde, schuilt het gevar voor desorientering van de arts.

"... the rapid growth of specialization confined many doctors to the treatment of a specific area of the body.... such specialization with its concentration on the organ served to obscure the fundamental concept of the patient as a total human being." (FIELD, M., 1967).

Wel is de moderne arts er zich van bewust dat hij nast zijn louter technische kennis ook nog andere takken van de wetenschappen bij zijn medisch handelen moet betrekken, doch, de enorme omvang van de vereiste kennis op louter somatisch gebied, beletten hem meestal om zich bijelk ziektegeval te gaan verdiepen in de geestelijke en matschappelijke aspecten van de aandoening, laat staan dat hij in staat zou zijn zich aan de studie van de psycho-sociale relaties te wijden. Wel kan hij in de regel in zijn dagelijkse praxis de noodzaak van een zekere belangstelling voor de matschappelijke en psychologische omgevingsfactoren rond de persoon van de patiênt ervaren. Wanneer evenwel dit studiegebied onlosmakelijk is opgenomen in het academisch opleidingspakket, is ook de kans aroter dat de praktijkvoering er door geconditio- 
neerd wordt. De resultaten van ons onderzok brengen een antword op deze vraastellingen.

2. 1. Evaluatie van de genoten academische opleiding.

Het uiteindelijk doel dat de overgrote meerderheid der medische opleiders, in casu de geneesheer-hoogleraren, nastreeft is : de studenten een begrip bijbrengen van medische basiskennis. Immers, zonder deze zou de wetenschappelijke beoefening van de geneeskunde onmogelijk zijn. Dit is echter niet voldoende. De basiskennis moet worden a angevuld met een reeks allernoodzakelijkste elementen, gevat in de bekwamheid die theoretische kennis in de praktijk om te zetten. Hieronder noemen we: de identificatie van de symptomen van vele andoeningen, het achterhalen wan medische gegevens over vroegere ziekten, de wijze van onderzoek van de patiënt, de interpretatie van de laboratoriumresultaten, het stellen van de diagnose, (en op basis van deze) de wijze van behandeling, enz... Of nu alle artsen deze bijgebrachte kennis en technieken op de meest volkomen wijze in toepassing brengen is moejlijk achterhalbaar, laat staan of deze kennis op adequate wijze werd a angeleerd, laat stan dat de steeds groejende, maar ook steeds meer gefragmenteerde kennis zelf kan worden bijgebracht. (EBERT,R.H., 1968).

Voldoende bekend is evenwel dat het verwerven van die basiskennis over een niet zo korte periode geschiedt en dat de enorme omvang van een objectief-zakelijke leerstot (de vele onzekerheden ten spijt) (Fox, R., 1957) de vroege, vak idealistische visie of de ambitieuze gevoelens van de betrokkene of ook nog het overtujgend enthousiasme van naastbestaanden. heeft teleurgesteld.

"Teacher of medicine sometimes rephrase the distinction between the clinical and pre-clinical years into one between the "cynical" and "pre-cynical" years. Psychological research supports this view, presenting attitude surveys which show medical students year by year scoring lower on "idealism" and 
higher on "cynicism"... though they develop cynical teelings in specific situations directly associated with their medical school experience, the medical students never lose their original idealism about the practice of medicine... "idealism" and "cynicism" must be seen as situational in their expressfons rather than as stabel traits possessed by individuals in greater or lesser degree (BECKER, H.S. en GEER, BL., 1958). De talloze en rijk gevarieerde antwoorden die de artsen als motivering van hun studiekeuze formuleren ( 6 ) accentueren het voorgaande en vinden we ook terug in hun kritiek op de genoten academische opleiding.

Een opleiding in de integrale geneeskunde is er vooralsnog niet : scherper geformuleerd "there is no concrete body of knowledge that can be labeled "comprehensive medicine" (HAMMOND,K.F. en KERN, Fr., 1959) warbij de auteurs er nadrukkelijk op wijzen dat een uitgebreide en volledige fejtenkennis in de kliniek verkregen, niet nodig zou zijn indien de medische opleiding de medische studenten zou stimuleren in de ontplooing van de zo gewenste attitudes op sociaal en psychologisch vlak ten overstaan van de patiënten en ten aanzien van de medische praxis.

"This last point concerning attitudes is felt to be important because as the program developed the medical educators in the clinic became increasingly convinced that the practice of comprehensive medicine is fundamentally a matter of an approach, a set of attitude, on the part of the physician". (BECKER, H.S., GEER,BL., e.a., 1961; DON, ., COLLETTE,P., HIMAR,N.A., 1957). Dat in het licht van de rolvervulling in de medische praxis de noodzakelijkheid van grondige onderzoeken over de opleiding in ons land dringt, moge blijken uit volgende vaststellingen. 
2.1.1. Beoordeling van de medische opleiding.

Het aantal artsen dat blijk geeft van een quasi globale positieve instellino ten anzien van de genoten medische opleiding is niet bijster aroot. Slechts $15 \%$ verklaren dat de opleiding adequat was en dat zij door voldoende persoonlijke contacten met hun hoogleraren aan dezen een persoonlijke raadgever hadden. Ongeveer eenzelfde antal spreekt $z i c h$ eveneens positief uit, maar verklaart aan hun hoogleraren geen persoonlijke raadgevers gehad te hebben.

Betrekkelijk negatief luidt echter het oordeel van $41 \%$ der ondervraagden. Al vinden de meesten van hen dat hun medische opleiding in de traditionele gebieden van de geneeskunde adequat was, dan zijn zij bepaald niet enthoesiast over de wijze warop de stof werd bijgebracht. Van persoonlijk contact met hun hoogleraren en derhalve van de fiquur van de "hoogleraar-raadgever" die in deze discipline als onmisbaar moet worden beschouwd, was bitter weinig te bespeuren. De rest (30\%) kan de genoten opleiding bezwaarlijk adequat noemen en het contact met de hoogleraar ontbrak volledig, kortom communicatie was volgens hen total onbestaand.

In deze algemene vaststellingen blijkende verhoudingen een weerspiegeling te zijn van de leeftijdsstructuur van de respondenten. Vooral de jongstgediplomeerden, meteen ook de jongste artsen met weinis praktijkervaring oordeelden duidelijk negatief. Oak van de onmiddellijk daaropvolgende jongere artsen zijn er driekwart die de opleiding niet zo adequat vonden. De naklank van een vanuit bepalde oogpunten gebrekkige opleiding, zal deze blijkbaar nog best in het geheugen tiggen.

Deze naar leeftijdsstructuur trapsgewijze dalende negatieve instelling vindt zijn verklaring in de vroegere studievoorwarden die alle onderlinge binding tussen docent, student en patiënt ten goede kwamen, als daar zijn: kleinere universitaire bezetting, geringere gerichtheid van het medisch onderricht op specialisatie, meer contacten tussen medische 
opleiders en studenten, meer contacten met meer pat iénten per capita, maar ook het opkijken naar de hoogleraar, enz...

ook naargelano het beoefend specialisme treden beduidende verschillen op (App. II.5.).

De meest negatieve kritieken komen van de huisartsen. De rigide studieproqramma's zijn blijkbaar de trieste tegenhanger van het rijk menselijk mozalek warmee de huisarts in zijn dagelijkse praxis wordt geconfronteerd. De uitgesproken negatieve instelling vinden we ook terug bij de rontgenspecialisten, de fysiotherapeuten, reumatologen, radio-radiumtherapeuten, kinderartsen, mondartsen en neuropsychiaters. Positiever klinkt het oordeel van de anesthesisten, chirurgen, orthopedisten en gynaecologen. Zij zijn nu ook precies de specialisten die de objectiviteit van hun specialisme als motivering van hun keuze aanvoerden en uit dien hoofde blijkbaar ook meer gediend waren met de overwegend technische aspecten van de leerstof. Dit kan afgeleid worden uit de meer specifieke kritieken.

2.1.2. Inhoud van de kritiek.

Meer dan een derde van de respondenten hebben hun kritiek duidelijk omschreven. (?)

Voor de onderwezen leerstof zelf stellen we vast dat vooral chirurgen, orthopedisten, neuropsychiaters, kinderartsen, fysiotherapeuten en radio-radiumtherapeuten het studieprogramma te zwar vinden, in die zin dat er enerzijds te veel nutteloze vakken worden gedoceerd, anderzijds vakken als psychologie, psychiatrie, preventieve geneeskunde weinig of zelts niet aan bod komen.

Dermato-venerologen, urologen, anesthesisten, cardiologen en pneumologen klagen vooral het feit aan dat er te veel getheoretiseerd wordt, dat dus de praktijkopleiding te kort schiet of beter gesteld, dat de kopelina theorie en praktijk (empirie) verwarloosd wordt. Finesses in de praxis, waronder ook informatie over urgente of kleine heelkundige 
ingrepen ressorteren, worden niet onderwezen.

De felste kritiek en ook meteen de meest frequente, betreft echter de menselijke contacten. Deze sluit deels a an bij de vakkritiek en bij de voorgaande tekorten.

zo klaagt de helft der betrokkenen expliciet het tekort aan contacten met zieken aan, evenzo het ontbreken van een opleiding over de mentaliteit en depsychologie van de patiënt, het tekort a an een specifieke opleiding voor de huisarts, enz... maar ook de professoren worden hierbij betrokken. zij zijn geen pedagogen, echt les geven doen zij niet, zij houden het bij massa-onderricht.

Dit is het oordeel van zeer veel mondartsen, huisartsen, klinische biologen en anesthesisten.

Concluderend stellen we dus vast dat de jongere generatie van artsen, meer specifiek ook de huisartsen het gebrek aan communicatie aanklagen en het gevoel hebben dat de onderwijzende opdracht van sommige hoogleraren eerder neerkomt op een zelftevreden exposé van hun specialistische kennis. De wijze van kennisoverdracht blijft in gebreke d.w.z. al te vaak wordt de louter technische kennis geisoleerd gezien van de zieke als persoon, worden heel wat vakken gedoceerd war de arts in zijn toekomstige praxis niets aan meent te hebben of worden belangrijke vakken niet of althans niet voldoende benadrukt.

Het onconfortabel en ontmoedigend gevoel war veel artsen, bij ons onderzoek betrokken, witing aan geven, alsmede de onzekerheid en ambiguiteit warvoor ze in bepalde therapeutische situaties staan, kunnen het resultat zijn van een flagrant gebrek aan aangepaste kennis en scholing, maar evenzeer aan een gebrek aan communicatie en interactie op sociaal en psychologisch vlak, zowel met de patientit als met hun medische radgevers die de grote meerderheid nooit in die functie hebben ontdekt. De persoonlijkheid van de arts als alter- 
natieve mogelijkheid mag hier echter niet worden uitgesloten, doch dit facet behoort niet tot onze bevoegdheid. Uit een aanzienlijk a antal brieven die als een soort a anvulling op de beantwoorde vragenlijst door de respondenten is toegevoegd, kan hun sociale stress duidelijk worden wargenomen, doch dit was niet noodzakelijk gekoppeld aan een negatieve instelling ten aanzien van de genoten opleiding.

Tenslotte kan ook niet worden voorbijgegaan aan de specifieke instelling van chirurgen en orthopedisten die hun technische aspiraties in de specialistische oplejding blijkbaar ingelost kregen.

2.2. De praktijkvoering.

Uit het voorgaande blijkt dat heel wat artsen van oordeel zijn of ervaren hebben dat de randmedische visie in de opleiding slechts minimale aandacht krijgt.

In dit hoofdstuk wordt thans onderzocht of en in welke mate in de praxis zelf de arts, hetzij in de vorm van een reelle inzet, hetzij in de vorm van een aantal attitudes, wardering weet op te brengen voor het betrekken van omgevingsfactoren rond het ziekteverschijnsel.

Ten einde en voldoende ruine informatie rond deze problematiek in te winnen, werd zowel onderzocht of en in welke mate de arts randmedische informatie in zijn praxis betrekt, of hij de sterk uitgebouwde paramedische infrastructuur in zijn private praxis te werk stelt of er naar verwijst en tenslotte hoe hij ze evalueert.

Een derde benadering met name een evaluatie van medisch teamwerk en een keuzevorming tussen individuele praxis of groepspraxis met motivering daarvan, verstrekt een meer global beeld over de integrale visie van de arts in de medische praxis. 
2.2.1. Randmedische informatie: routine of casuistiek?

Tweevijfden van de respondenten hechten aan het inwinnen van randmedische informatie een routine-karakter en meer dan de helft houdt het bij de specificiteit ervan. Dergelijke informatie wordt dus enkel ingewonnen in specifieke gevallen.

Het antwoord differentieert enkel naargelang de Leeftijd der respondenten. Vooral oudere artsen houden het bij een rout ine-aangelegenheid.

Relevanter zijn echter de verschillen wanneer de vraagstelling gericht wordt naar welke en hoeveel omgevingsfactoren de arts in zijn praxis betrekt (8). Uit de antwoorden distilleren we volgend tabelletje dat voldoende duidelijk spreekt :

Tabel 4. Aantal items door de artsen in hun praxis als routine-informatie beschouwd.

\begin{tabular}{|c|c|}
\hline Aantal items & $\%$ artsen \\
\hline 2 & 16 \\
$3-5$ & 41 \\
$6-8$ & 30 \\
$9-12$ & 13 \\
\hline
\end{tabular}

Ruim meer dan de helft van de artsen oordelen dus dat, wanneer er toch van routine kan gesproken worden bij het inwinnen van dergelijke informatie, dit voor een klein a antal items volstat.

Gedifferentieerd naar specialisme stellen we vast dat het bij uitstek de neuropsychiaters, anesthesisten, $k l i-$ nische bialogen, röntgenspecialisten en kinderartsen zijn die oordelen dat een ruime reeks omgevingsfactoren voor routineinformatie in aanmerking komen (App.II.10).

2.2.2. De paramedische infrastructuur.

In ons huidig medisch systeem is als directe beantwoording aan de noden van de artsenpraxis, een reeks parame- 
dische (lager gekwalificeerde) beroepen en diensten tot stand gekomen, warop de arts beroep kan doen, net als hij de hulp van zijn (eveneens) gespecialiseerde collega's op louter medisch-technisch vlak kan inroepen.

Waar de geneesheer zelf voorzan in een reeks niet louter medische tegemoetkomingen, kan hij thans zowel de verplegende taak (die zeer vroeg in de medische praxis geintegreerd was) ats de psycho-sociale begeleiding, maar ook de steeds groejende technische verantwoordelijkheden toewijzen aan een ruime gamma van paramedische hulpkrachten en diensten. Dit neent echter niet weg dat zij buiten het medisch denken van de arts mogen worden geplatst. Op deze voorzieningen moet hij echter een beroep doen, opdat hij dié taken die normal onder zijn lowter medische bevoegdheden vallen, naar behoren zou kunnen vervullen.

Het ligt niet in onze bedoeling de sociale identiteit van dit medico-sociaal equipement in zijn geheel an een diepere analyse te onderwerpen, doch enkel na te gaan of de arts van dit equipement gebruik makt en welke wardering hij eraan toekent.

Bekend met de evaluatie door de artsen van de omgevingsfactoren, wordt thans nagegaan of de arts, behoudens zijn persoonlijke inzet, onk nog andere middelen ziet, in casu de hulpkrachten om deze informatie desgevallend te recupereren.

zo gesteld, wordt in dit hoofdstuk op volgende vragen een antwoord verstrekt :

- aan wie hoort het volgens de artsen informatie in te winnen;

- stelt de arts in eigen praxis een hulpkracht tewerk of verwijest hij;

- hebben de artsen reeds gunstige ervaring gehad bij het optreden van een hulpkracht en in welke mate. 
2.2.2.1. Aan wie hoort het randmedische informatie te verzamelen?

In zekere zin reeds evaluerend van aard, treden bij deze vraagstelling twee overwegende antwoordcategorie ên nar voor. Enerzijds zijn er tweevijfden van de respondenten die oordelen dat de arts best zelfstandia handelt, anderzijds eenzelfde aantal die de sociale assistent (matschappelijk werker) als de geschikte persoon anduidt. De resterende artsen houden het ofwel bij de verpleegster of de medisch secretaresse. Een weinig noemenswardige minderheid zien in deze opdracht zowel een taak van de arts als van een paramedische hulpkracht.

Plattelandsartsen meer dan hun stedelijke collega's plaatsen de arts zelf in deze "informatieve opdracht", wat tegrijpelijk is uit hoofde van hun isolement. Als tegenhanger zien we dan dat de stadsarts cvooral die met een praktijk in woongebieden van de hogere sociale lagen) meer dan de andere artsen, de sociaal assistenten en verpleegsters in deze opdracht zien.

Naar specialisme valt het op (App.II.11.) dat het inwinnen van die informatie vooral door de neuropsychiaters aan de sociaal assistent wordt toegewezen. Ook de gynaecologen vinden zulks, daar war mondartsen, anesthesisten, keel-, neus- en oorspecialisten en oogartsen de arts aanduiden.

2.2 .2 .2 . Paramedici in de private praxis.

De kennis dat een kleine tweederde van de respondenten het inwinnen van bedoelde informatie als een a angelegenheid typeert die tot de bevoegdheid van de paramedici befoort, kan enkel als een preliminaire wardering gelden.

In de hiërarchische structuur van elk ziekenhuis is de paramedische toerusting sterk organisatorisch geintegreerd en bekleedt er een duidelijke statuspositie. In hoeverre evenwel de artsen met hun uitspraak de paramedici in hun sociaal relatiepatroon weten te plaatsen, hen naar warde weten te 
schatten en hen bovendien een zeker gezag toekennen, blijft voor wat de private praxis betreft, vooralsnog een vraagteken. Derhalve werd onderzocht, niet enkel of de artsen deze hulpkrachten in hun private praxis aanwenden, maar ook als noodzakelijk alternatief of zijernaar verwijzen. Als derde matstaf van betrokkenheid werd ook nagegaan welke wardering ze aan de werking zelf van deze hulp toemeten.

zonder rekening te houden met het niveau van de opleiding die zeer verschillend kan zijn, onderscheiden we thans in ons land een dertigtal paramedische beroepen. De opzet van ons onderzoek noopt ons echter niet tot een detailanalyse, zodat we deze grote differentiatie in een vijfledige classificatie condenseerden. We onderscheiden : verplegend, sociaal, psychologisch, technisch en administratief personeel.

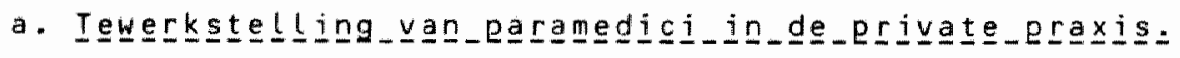

Driekwart van de respondenten beofenen een private praxis (9). De hiernavolgende resultaten zijn op deze van toepassing.

Tabel 5. Aard van de tewerkstelling van paramedici in eigen praxis.

\begin{tabular}{|c|c|c|c|c|}
\hline \multirow[t]{2}{*}{$\begin{array}{l}\text { Categorie van } \\
\text { paramedici }\end{array}$} & \multicolumn{3}{|c|}{$\begin{array}{c}\text { Aard van de tewerkstelling } \\
\text { Cprocent artsen }\end{array}$} & \multirow[t]{2}{*}{ Totaal } \\
\hline & $\begin{array}{l}\text { geen } \\
\% \\
\end{array}$ & $\begin{array}{c}\text { occasioneel } \\
\% \\
\end{array}$ & $\begin{array}{c}\text { in vast } \\
\text { verband } \\
\%\end{array}$ & \\
\hline $\begin{array}{l}\text { verplegend } \\
\text { sociaal verplegend } \\
\text { psychologisch } \\
\text { technisch }\end{array}$ & $\begin{array}{l}74 \\
90 \\
79 \\
79\end{array}$ & $\begin{array}{r}10 \\
7 \\
8 \\
8\end{array}$ & $\begin{array}{r}16 \\
3 \\
13 \\
13\end{array}$ & $\begin{array}{l}100 \% \\
100 \% \\
100 \% \\
100 \%\end{array}$ \\
\hline
\end{tabular}

Het administratief personeel wordt niet in de tabel opgenomen, daar het niet kan worden beschouwd als een rechtstreekse schakel tussen arts en patiënt. 
Samenvattend kan gezegd worden dat verplegend personeel door meer dan een kwart der respondenten teverkgesteld wordt. Het psychologisch en technisch gevarmd personeel komt tweede in rang. Het minst gewardeerd blijkt het sociaal verplegend personeel te zijn.

$\mathrm{Nu}$ is het wel zo dat het social verplegend beroep niet zo sterk in hiërarchisch gerangschikte posities is uitgesplitst als de verplegenden, wat zijn integratie in de private praxis kan bemoeilijken, tenzij er een onderwardering door de arts aan de basis van ligt.

Verder stellen we vast dat verplegend, technisch en administratief personel vooral in vast verband in stedelijke woongebieden van de hogere sociale lagen wordt tewerkgesteld. Verplegend en technisch personeel worden bovendien ook, mar dan eerder occasioneel, door artsen wit kleinere steden a angewend. Administratief personeel vindt eerder een kans in stedelijke woongebieden van de lagere sociale lagen.

Naar specialisme gedifferentieerd kunnen de resultaten als volgt worden samengevat: (App.II.12.)

- verplegend personeel

: in vast verband bij $k l$ in ische biologen, röntgenspecialisten, chirurgen, orthopedisten, dermato-venerologen, urologen, internisten en gastro-enterologen:

occasioneel : vooral bij chirurgen, arthopedisten en röntgenspecialisten:

- sociaal verplegend personeel

: in vast verband bij neuropsychiaters; occasioneel : idem;

- psychologisch personeel

: in vast verband én occasioneel

- technisch personeel

: in vast verband : klinische biologen, fysiotherapeuten, reuma tologen, radio-radium therapeuten, róntgenspecialisten; occasioneel : idem. 
Concluderend kan worden gesteld dat de huisarts, behoudens verwijzing naar de familiale helpster en medisch sociale diensten, geen uitzonderingspositie bekleedt.

b. Het_verwílzen:

Voor randmedische taken stat voor de arts ook nog het verwijzen naar gespecialiseerd personeel als direkte mogelijkheid open.

De hieronder verstrekte resultaten hebben op alle respondenten betrekking daar zowel in de private als in de verbonden praxis het verwijzen een belangrijke plaats bekleedt.

Een aanzienlijk aantal artsen verwezen reeds patiënten naar een of andere hulpkracht, hoewel het verwijzen naar een medico-sociale dienst vooraan op de lijst staat: Tabel 6. Procent artsen die verwijzen naar hulpkrachten.

\begin{tabular}{|c|c|}
\hline Categorie van hulpkrachten & $\begin{array}{c}\text { Procent verwijzende } \\
\text { artsen }\end{array}$ \\
\hline $\begin{array}{l}\text { arbeidstherapeut, diêtist, } \\
\text { logopedist, enz... } \\
\text { social verpleger, sociaal } \\
\text { assistent, enz... } \\
\text { psycholoog, psychologisch } \\
\text { assistent... } \\
\text { familiale hulp }\end{array}$ & $\begin{array}{l}26 \\
24 \\
22\end{array}$ \\
\hline
\end{tabular}

Sociaal milieu van de praktijk en verwijzen naar paramedici vertoont een significante relatie. Bijna de helft van de plattelandsartsen verwezen hun patiënten reeds naar een familiale helpster of een medico-sociale dienst, wat een aanvulling betekent voor hun afwezigheid onder de artsen die paramedici tewerkstellen.

Stadsartsen uit sociale woongebieden van de hogere sociale lagen spreken het meest arbeidstherapeuten, diètisten en dergelijke aan voor verwijzing.

Het verwijzen komt eerder overwegend bij artsen met privatè praxis voor. Het zijn bij uitstek huisartsen, mar ook 
wel kinderartsen. De neuropsychiaters zijn specialisten die veel meer dan alle andere artsen verwijzen naar paramedici die op sociaal en psychologisch vlak bevoegd zijn. Gynaecologen verwijzen meer eens naar familiale helpsters, terwijl keel-, neus- en oorspecialisten, oogartsen, dermato-venerologen en urologen meer naar ergo-therapeuten, dietisten en logopedisten verwijzen (APp.II.13.)

2.2.2.3. Evaluatie van de ervaren paramedische tussenkomst. Om een te grote versnippering van de resultaten te vermijden werden de antwoorden per respondent in én enkele variabele uitgedrukt. Zij informeert ons aldus over de toenemende ervaring (of geen) bij het optreden van éen, twee, drie enz... van de vijf onderscheiden hulpkrachten of diensten.

Tabel 7. Procent artsen die reeds gunstige ervaring hadden met paramedische tussenkomsten.

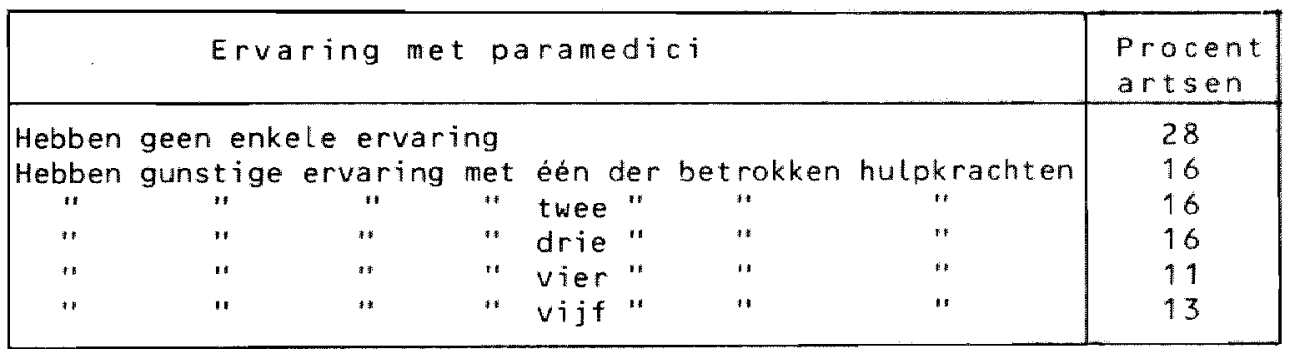

Het verwijzingspatroon dat we onder b. zagen, wordt hier duidelijk gereflecteerd in die zin dat, hoe meer gunstige ervaring artsen hebben met paramedici, des te meer het artsen betreft die reeds verwezen naar hulppersoneel. Een identieke samenhang stellen we vast bij een confrontatie met het al dan niet tewerkstellen van dit personeel in de private praxis.

Geen ervaring hebben vooral klinische biologen, keel-, neus- en oorspecialisten, oogartsen, röntgenspecialisten en mondartsen (APp.II.14). Het meest ervaring hebben de neuropsychiaters. Gunstige ervaring met een bredere waater van hulpkràchten hebben vooral cardiologen, longartsen, internis- 
ten, gastro-enterologen, pediaters en huisartsen.

Samenvatting.

Indien de arts langs zijn wetenschappelijke nieuwsgierigheid, zijn zin voor verder onderzoek of zijn belangstelling voor het detail, het wetenschappelijk element als noodzakelijke component van een begrijpende geneeskunde in zijn beroepsrol wil onderhouden, dan kan een integrale visie op de persoon van de zieke gemakkelijk verloren gaan.

om hieraan te ontsnappen zal de arts in de loop van zijn professionele socialisering dan ook verplicht zijn, nast zijn louter persoonlijke belangstelling en daaraan gekoppelde individuele inzet op randmedisch gebied, beroep te doen op een reeks minder gekwalificeerde beroepen, met name de paramedici.

De meerderheid der respondenten erkent het belang van de sociale en psychologische context van de patient in relatie tot zijn ziekte. Het inwinnen van dergelijke informatie wordt door ruim meer dan de helft van hen als een routine-aangelegenheid beschouwd, warbij de oudere artsen relatief overwegen.

vooral de neuropsychiaters betrekken een groot aantal jtems in hun ziektebehandeling.

De bevoegdheid voor het inwinnen van die informatie kent de meerderheid toe a an paramedici. Dit betekent niet dat $2 i j$ in dezelfde mate dit gekwalificeerd personeel in hun private praxis tewerkstellen.

Zo wordt de medische secretaresse het meest aan een private praxis verbonden, mar alle overige paramedici komen in verre na niet op de hoogte van dit administratief gevarma personeel. De social assistent behalt de meeste "voorkeurstemen" maar wordt in feite nauwelijks in de private praxis aangewend. Uitzondering hierop makt wel de neuropsychiater war deze hulpkracht kennelijk naar warde wordt geschat. 
Dit alles neemt niet weg dat de overgrote meerderheid der respondenten toch reeds enige ervaring (duidelijk gunstige) hebben gehad met deze hulpkrachten. Immers, bijna driekwart van hen, mar andermaal de neuropsychiaters bijuitstek, verklaren dit witdrukkelijk.

2.2.3. Medisch teamwerk.

Door de moderne uitbouw van de geneeskunde die juist door zijn specialisatie steeds meer tot samenwerking noodzaakt, is voor een beoordeling van de gezondheidszorg de kwaliteit van het teamwerk van grote betekenis.

Derhalve werden de artsen witgenodigd hun visie mee te delen over de meer formele samenwerking van medisch en paramedisch personeel die we heden ten dage terugvinden in het medisch team.

Gezien de beperkte doelstellingen die worden nagestreefd, wordt geen aandacht verleend aan de uiterst complexe situatie die een medisch team in feite uitmakt, doch enkel de nadruk gelegd op de wardering ervan door de betrokken artsen.

2.2.3.1. Evaluatie van de samenwerking.

$$
\text { Medisch teamwerk wordt door tweevijfden van de } 1640
$$

respondenten vooral gewardeerd omwille van de samenbundeling van de technische kennis als omwille van de intense samenwerking voor het welzijn van de patiënt. Bijna evenveel artsen stellen geen van betde elementen central. De resterende respondenten stellen, gelijkmatig verdeeld, slechts éen van beide elementen central. In de eerste categorie vinden we vooral ziekenhuisartsen, hoewel deze ook duidelijk vertegenwoordigd zijn onder hen die enkel de samenbundeling van de technische kennis central stellen. Private artsen treffen we bij voorkeur aan in de categorie die geen van beide elementen central stellen, wat er kan op duiden dat $z i j$ geen belangstelling hebben voor teamwerk (App.III.1.) 
Bijzonder is wel de vaststelling dat artsen die veel ervaring hebben met paramedisch personeel, meer integraal ingesteld zijn dan de rest. Genoemde ervaring blijkt echter ook samer te gaan met het accentueren van de neer technische inbreng. Onder de individuen die vooral het welzijn van de patient benadrukken, treffen we de artsen an die geen ervaring hebben met paramedici. Gezien het kleine aantal betrokkenen menen we ons van enige interpretatie te moeten onthouden.

Tenslotte is er ook een duidelijke relatie naargelang het beoefend specialisme (App.II.15). Anesthesisten, cardiologen, pneumologen en internisten die veel in teamverband werken, blijken meer dan hun overige collega"s het teamwerk integraal te wa arderen. De technische samenbundeling wordt vooral door dermato-venerologen, urologen en kinderartsen geapprecieerd, het welzijn van de patiênt vooral door de neuropsychiaters.

Huisartsen en mondartsen onthouden zich van enige bijzondere appreciatie.

2.2.3.2. Evaluatie van de gedeelde verantwoordelijkhejd.

redeelde verantwoordelijkheid in een medisch team wordt belangrijk geacht door artsen die ook veel belang hechten aan de technische samenbundeling en aan het welzijn van de patient. Gesteld kan worden dat deze artsen het medisch teamwerk ten volle weten te warderen. Immers omgekeerd, zien we dat, wanneer geen bijzonder belang wordt gehecht aan de eerste twee elementer, de artsen evenmin gedeelde verantwoordelijkheid centraal stellen. Medisch teamwerk betekent wa schijrlijk niet zo weel voor hen.

Deze instelling hangt nauw samen met de leeftij. zo hechten oudere artsen meer belang a an de gedeelde verantwoordeli kheid, hoewel een opvallend a antal onder hen eerder gat twijfelen over de gestelde problematiek en zich dan ook niet radicaal uitspreken. 
Anesthesisten, cardiologen en longartsen, ook wel de röntgenspecialisten beschouwen de gedeelde verantwoordelijkheid als zijnsgebonden an medisch teamwerk. Dit is echter niet het geval voor de chirurgen, orthopedisten en neuropsychiaters. Deze instellling kan er op wijzen dat vooral deze specialisten uit hoofde van de specificiteit van hun discipline de persoonlijke inbreng als ondeelbaar beschouwen.

2.2.4. Groepspraktijk of individuele praktijk.

2.2.4.1. Inleiding.

Dat door de steeds meer gefragmenteerde medische opleiding en de er wit voortspruitende specialistische praktijken, interdisciplinaire samenwerking een steeds grotere noodzakelijkheid wordt, is een feit. Deze evolutie naar informele groepen is duidelijk vast te stellen, mar wijst nog niet naar een doar de meerderheid gewenste groepspraktijk. Opinies en wensen, kritieken en verantwoording terzake lopen sterk uiteen.

Toen G.Wilson in 1922 een artikel wijdde an deze problematiek (WILSON, G., 1922) dacht hij waarschijnlijk niet dat 50 jaar later groepspraxis nog niet zou ingeschakeld zijn in de beroepsuitoefening van huisartsen.

In de loop der jaren ging de medische praxis evenwel meer extensieve vormen a annemen. Nieuwe organisatievormen eisten adequate uitrustingen die de individuele praxis niet kon dragen. De hospitalen konden deze investeringen wel dragen en spoedig kwamen nieuwe specialismen deze uitdainende medische centra als essentieel onderdeel aanvullen (10).

De grote meerderheid der artsen bleef echter de individuele praxis beoefenen en kwam hoogstens tot informele samenwerking, die echter het nadeel van hogere kwestbarheid heeft. Hieruit vloeit niet enkel voort dat de positie van de samenwerkende partijen zelf kan worden bedreigd, maar dat ook de continuiteit van de zorg aan de zleke in het gedrang kan komen. Als dat zo is, dan zou enkel de formele samenwerking een oplossing kunnen bieden. 
Maar om het even onder welke vormelijke gedaante de groepspraxis verschijnt, behalve wanneer slechts énzelfde specialisme in de groep vertegenwoordigd is, "it is hard to see how it differs from the partnerschip" (FREEMAN,H.E., LEVIN,S., REEDER,L.G., 1963).

Wat er ook van zij, gezaghebbende informatie over de betekenis van de groepspraktijk is moeilijk te verkrijgen (11).

Ter situering evenwel, kan gezegd worden dat de private praxis (solo-praxis), zowel van huisarts als van specialist kan worden vergeleken met een "one man" organisatie die enkel groeit in en dank zij een professionele omgeving.

op grond van de resultaten van ons onderzoek zijn we geneigd de groepspraxis als wig tussen beide voorgande systemen te incorporeren.

Misschien kan, als uitgangspunt voor verder onderzoek, het hier weergegeven schema in overweging genomen worden.

\begin{tabular}{|c|c|c|}
\hline $\begin{array}{l}\text { Private praxis } \\
\text { van huisarts of } \\
\text { van specialist }\end{array}$ & $\begin{array}{c}\text { - menselijke } \\
\text { contacten }\end{array}$ & $\begin{array}{l}\text { (Lay-referral } \\
\text { systeem) }\end{array}$ \\
\hline Ziekenhuispraxis & $\begin{array}{l}\text {-diversiteit } \\
\text { kennis } \\
\text {-efficiënte } \\
\text { praxis }\end{array}$ & $\begin{array}{l}\text { (Professional } \\
\text { referral sys- } \\
\text { tem) }\end{array}$ \\
\hline Groepspraxis & $\begin{array}{l}\text {-menselijke } \\
\text { contacten } \\
\text { - diversiteit } \\
\text { kennis } \\
\text {-efficieante } \\
\text { en continue } \\
\text { praxis }\end{array}$ & $\begin{array}{l}\text { (socio-profes- } \\
\text { sional refer- } \\
\text { ral system) }\end{array}$ \\
\hline
\end{tabular}

Uit dit schema moge voldoende blijken dat een evaluatie-onderzoek wordt bedoeld naar de functies en dysfuncties in de drie systemen. We beperken ons tot deze suggestie, maar pogen aan de hand van ons onderzoekingsmateriaal 
de richting te evalueren die de medische praxis in ons land opteert.

Doet het studiematerial wel iswar vooralsnog beperkt aan, dan laat het toch in ruime mate toe na te gaan hoe ons artsenkorps denkt over het niet zo recente probleem van de groepspraxis. Te dien einde werden de artsen verzocht een keuze voorop te stellen en vervolgens deze keuze te verantwoorden.

2.2 .4 .2 . Resultaten van het onderzoek. De voorkeurshouding.

$54 \%$ der respondenten drukken zich wit voor groepspraxis, $43 \%$ laten hun keuze vallen op de individuele praxis; $3 \%$ geeft blijk van een geconditioneerde voorkeur voor beide praxisvormen (12).

Artsen van beneden de 50 jaar spreken zich meer dan de oudere artsen uit voor groepspraxis, vaststelling die ook geldt voor de geconditioneerde voorkeur.

Een duidelijk significante relatie blijkt eveneens uit een confrontatie met de sociale omgeving war de arts zijn praktijk heeft (App.III.Z). Zo geven de plattelandsartsen veruit het duidelijkst hun voorkeur te kennen voor de individuele praxis, hoewel artsen die in stedelijke woongebieden van de hogere sociale lagen gevestigd zijn in dezelfde zin opteren. Daartegenover staan dan de artsen uit stedelijke woongebieden van de lagere sociale lagen wier voorkeur naar de groepspraxis gat.

De geisoleerdheid van de plattelandsarts enerzijds en het streven naar erkenning, mar vermoedelijk ook de meer lucratieve omgeving van de stadsarts in het woongebied der hogere sociale lagen, dicteert wellicht deze individualistische houding.

Evident is witeraard ook de verschillende voorkeurshouding van artsen met private en artsen met verbonden praxis. Meer dan de helft der private practici verkiezen de individuele praxis, tegenover nauwelijks $17 \%$ van de ziekenhuisartsen. 
Significant is vervolgens de relatie met de evaLuatie van het medisch teamwerk. Artsen die het medisch teamwerk naar de onderscheiden elementen positief beoordelen, richten hun voorkeur veel sterker dan de anderen naar de groepspraxis.

De steeds groeiende fragmentatie van de medische kennis en haar repercussies op het antal specialismenen superspecialismen dicteert blijkbaar ook een differentiërende instelling. Immers nat specialisme onderscheiden (App.II.17), zijn de huisartsen veruit het sterkst gewonnen voor de individuele praxis (ruim meer dan tweederde). Dit staat duidelijk in tegenstelling tot de resultaten van een onderzoek ander vlaamse huisartsen, warvan zich "een meerderheid expliciet voorstander verklaart van groepsgeneeskunde" (NUYENS, Y., 1976).

Uit ons onderzoek dat national is gericht kan er aldus niet besloten worden tot een "discrepantie tussen opvatting en gedrag, tussen ideologie en realiteit".

Immers, wanneer we de motiveringen van de voorkeurshoudingen nagaan, verklaren de huisartsen ondubbelzinnig dat zij de individuele praxis verkiezen omdat zijoordelen dat, bij solo-praxis de individuele binding tussen arts en patiënt gemakkelijker tot stand komt, dat verantwoordelijkheid en toewijding zich beter bij een enkeling dan bij een groep kan ontplooien, dat de vrije keuze van een arts beter gegarandeerd wordt, wat de persoonlijke verhouding tussen arts en patient verzekert. Hun voorkeur verantwoorden somigen ook door te verklaren dat zij eigenlijk geen kennis hebben aver groepsgeneeskunde (onzekerheden), dat zij het nu eenmal gewoon zijn in hun solo-praxis, maar ook dat zij niet goed inzien - en dit geldt dan vooral de plattelandsartsen - hoe een groepspraxis zou kunnen worden uitgebouwd. Lij denken vooral a an generatieverschillen en ecologische ongelijkenissen. Is er dan toch een gevoelige minderheid van onze huisartsen die groepsgeneeskunde voorstat, dan weten zij deze voorkeur op sterk significante wijze te verantwoorden door er op te wijzen dat 
groepspraxis "verruimen van de medische kennis" betekent.

Wat de specialisten betreft, zijn ook opmerkelijk meer dan hun overige collega's, de dermato-venerologen, urologen, keel-, neus- en oorspecialisten, oogartsen en mondartsen voor de individuele praxis gewonnen (meer dan de hel $f t$ ).

Afgezien van de vele pleidooien voor en kritieken op respectievelijk de individuele en de groepspraxis die we hier niet analyseren, kunnen we cancluderen dat ruim meer dan de helft van de respondenten gewonnen is voor de groepsgeneeskunde.

Na dit onderzoek zijn er enkele pogingen tot coördinerend overleg tussen jongere artsen geweest. Er zijn ook enkele, $z i j$ het op ideologische gronden berustende realisaties gekomen, warvan kan gezegd worden dat zij het karakter dragen van moedige pogingen tat het creëren van op dit ogenblik nog uiterst labiele structuren in de gezondheidszorg.

Maar, uit aanvullende informatie die hier niet wordt verwerkt en die betrekking heeft op de samenstelling en coördinatie binnen de medische groep, blijkt dat de diversiteit der samenstellende elementen zo immens is en bovendien zo sterk wordt geconditioneerd door, zowel individuele als sociale factoren, dat we de indruk hebben nog heel ver van een definitieve vormgeving verwijderd te zijn.

De geest van de groepspraxis is misschien hier en daar doorgedrongen, maar van een gefixeerde vorm warop verder kan worden gebouwd, kan voorlopig moeilijk sprake zijn. 
HOOFDSTUK 3. OORDELEN OVER DE SOCIAAL-PSYCHOLOGISCHE ACHTERGRONDEN EN DE PREVENTIE IN OE PRAKTIJKVOERINS.

INLEIDING.

Het witsluitend verwerven van technisch-specialistische kennis gedurende de academische opleiding en ook nadien kan de arts intellectueet isoleren.

Wil hil an zijn sociale rolvervulling niet voorbijgaan, dan moet hij weten dat de geneeskunde zowel een sociale als een fysische en biologische wetenschap is. Querido indachtig (1955), moet hij dan ook continu en simultaan de sociale, psychische en somatische belasting van de ziektebenadering in zijn beroepsuitoefening weten te betrekken en ook overtuigd zijn van de warde van de preventieve interventie als element van de begrijpende geneeskunde.

In ons onderzoek geven een viertal indicatoren antwoord op deze problematiek. Samen vormen zij een variabele die uit een factoranalyse is tot stand gekomen.

op het preventief element wordt dieper ingegaan omwille van zijn actualiteit. De socio-preventieve voorzieningen heden ten dage zijn dermate uitgebouwd, dat ze voor de arts een uitnodiging kunnen zijn om de persoonlijke inzet op dit vlak te verwarlozen. Hem wordt dan ook gevraagd:

- zijn wardering te verstrekken voor deze voorzieningen;

- een aantal statements te evalueren die hem in zijn preventieve attitude terzake tekenen.

Twee notities leken ons tenslotte, behoudens het a an dit vertechniseren van de geneeskunde aansluitend sociologisch corollarium, noodzakelijk toe te voegen.

Enerzijds stelt zich de vraag welke plats de arts in zijn praxis toekent aan het louter curatief optreden, anderzijds - en dit wordt dan toegespitst op de huisarts - heeft, ingevolge het toenemend antal specialisten, de verantwoordelijkheid van de huisarts een andere dragijidte gekregen? 
3.1. Specjalisatie en sociaal-psychologische contaxt van de praxis.

De vier samenhangende statements die deze problema-

tiek belichten luiden:

- De medische studies zouden meer op specialisatie dan op de algemene geneeskunde moeten worden gericht:

- Het kader van de medico-sociale diensten is in de moderne samenleving reeds zo uitgebreid, dat de arts zijn tijd niet meer hoeft te verliezen om problemen van persoonlijke, familiale of professionale aard van de patienten te bespreken of op te lossen;

- Bovendien is de specifieke kennis die nodia is om aan medico-sociale preventie te doen op dit ogenblik nog zo beperkt, dat de arts veel beter zijn tijd besteed a an louter curatieve zorg;

- Voor de arts is het belangrijker dat hij zijn technische kennis perfectioneert, dan dat hij zijn ervaring met de persoon en het milieu van de patiënt verrijkt.

Daar er een quasi evenredige spreiding in de antwoordmogelijkheden optrad, werden deze in vier kwarten ingedeeld:

- het eerste kwart betreft artsen die de statements als geheel moeilijk kunnen bijtreden;

- het tweede kwart zijn artsen die enige reserve stellen;

- het derde kwart weet zich moeilijk uit te spreken;

- het laatste kwart betreft respondenten die de hen voorgelegde statements volledig beamen.

opvallend is de sterke samenhang met de leeftijdsstructuur van de respondenten (App.III.3.). Zelfs bij de overweging dat de arts in de huidige praxis beroep kan doen op tal van medische voorzieningen, zijn het vooral jongere artsen die van mening zijn dat de persoonlijke inzet inzake sociopsychologische ongevingsfactoren hoog dient angeschreven. zoals ook mocht blijken uit hun kritiek op de medische opleiding, staan de jonge artsen voor dat het accent hierin op de algemene praxis zou moeten worden gelegd. 
Enige reserve t.a.v. de vier statements stellen vooral artsen van beneden de 50 jaar. Voor een ander kwart bestaat de problematiek reêl. Terzake weten zij niet welke houding precies aan te nemen en tot deze "twijfelaars" behoren vooral de artsen van 40 tot 50 jaar die minder dan 15 jaar praxis hebben.

Het laatste kwart zijn artsen die volledig beamen dat in de opleiding het accent dient gelegd te worden op specialisatie en dat het modern paramedisch equipenent er is om te gebruiken. Central wordt de technische vakkennis gesteld en voor rand-medische tussenkomsten is er geen $t i j d$.

Uit de resultaten blijkt onbetwistbar dat een dusdanige instelling dié is van artsen ouder dan 50 jar. Bij Litstek blijken zij ook artsen te zijn die niet precies weten of het inwinnen van informatie over milieufactoren specifiek moet gebeuren bij bepaalde zieken of bij bepaalde aandoeningen. Blijkbaar kiezen ze dan mar het zekere boven het onzekere en doen zij liefst beroep op paramedische voorzieningen.

Verder komt duidelijk naar voor dat de neuropsychiaters een academische opleiding voorstaan die in eerste instantie op de algemene praxis moet worden gericht. Bovendien oordelen $z i j$ dat randmedische interesses, niettegenstaande de ruime deskundige voorzieningen op dit gebied, toch de persoonlijke inspanning van de arts moeten blijven oproepen. Deze specialisten weten blijkbaar goed dat enkel persoonlijke benadering van de patient verhelderend kan inwerken op aangeboden aandoeningen. Deze multiconditionele instelling vinden we ook bij de huisartsen terug, wat te verwachten viel (APp.II.18).

Enigszus onverwacht hoort hier ook nog een relatief hoger aantal klinische biologen bij. Een verklaring hiervoor zou kunnen gevonden worden in hun uitgedrukte belangstelling voor andere specialistische disciplines enerzijds (13) waronder figureren de dermato-venerologen, kinderartsen, inwendige geneeskunde, cardiologen, anesthesisten, longartsen en oogartsen - en de uit hoofde van hun specialisme multi- 
disciplinaire contacten anderzijds. Mogelijk zijn het personen die, aangezien zij "artsen zonder patienten" ziju, uit lectuur en niet zo zeer specialistische lectuur (13), de patiënten als gehele persoon percipiëren.

Enige reserve t.a.v. de statements stellen vooral de kinderartsen, cardiologen, longartsen, ook nog wel huisartsen en mondartsen. "Onbeslist" is de uitspraak van de fysiotherapeuten, reumatologen, radio-radiumtherapeuten en anesthesisten; allen precies duidelijk technische specialismen.

Tenslotte is er de categorie van respondenten die van oordeel $z i$ in dat in de academische opleiding de specialisatie moet primeren. Zij oordelen bovendien ook dat de medico-sociale infrastructuur voldoende is uitgebouwd, opdat de arts niet langer meer zelf zou moeten instaan voor deze randmedische bemoeingen. Deze visie wordt in het bijzonder door de chirurgen en orthopedisten gedeeld, verder ook door de mondartsen, keel-, neus- en oorspecialisten en oogartsen. Mogelijks gat het hier om artsen die het psycho-sociale gebied der geneeskunde te sterk als een aparte wetenschap zien, die zij niet weten te integreren in de continue stroom van nieuwe specialistische technieken die zij wél op de voet volgen. 3.2. Waardering van het preventief element.

Preventieve geneeskunde betekent de aanwending in de geneeskunde van de voorhanden zijnde middelen tot het voorkómen van een ziekte of tot het verhoeden van het verergeren van deze.

In de huidige constellatie van de moderne geneeskunde denken we dan in de eerste plats aan de controle van openbare gezondheidsdiensten die, langs een stelsel van normen hoe a anvechtbaar die ook moge zijn - en voorschriften, vastgelegd in ecn reeks wettelijke bepalingen, instaan voor de matschappelijke, preventieve gezondheidszorg, als onderdeel van de sociale geneeskunde. Nast de openbare instellingen, blijft nog de individuele tussenkomst van de praktizerende arts. Te veel zieken echter raadplegen, zonder tussenkomst van 
de huisarts, rechtstreeks de specialist. Dit is zeer gewoon in Belgie. Nochtans is de huisarts de aangewezen figuur om het gezin van de patiënt van dichtbij te leren kennen en dit is belangrijk. Immers, door dit persoonlijke contact heeft hij kennis van de hygiënische levenswijze, van de psychische toestand en voedingsgewoonten (VAN GOOR, I.A., 1961) en kan hij derhalve door eventueel advies, ervoor zorgen dat genoemde situaties geen anleiding worden tot ziekte. In deze bijzondere positie heeft hij aldus de kans mensen te zien voor zij ziek zijn en hen te adviseren hoe hun gezondheid te beveiligen. De specialist beschikt niet over deze mogelijkheden. Nochtans is hij door zijn - althans in Belgie directe bereikbarheid, mar ook op zijn specialistisch niveau, erg op zijn njveau dus, erg betrokken bij de preventieve gezondheidszorg. Denken we enkel aan de werking van laboratoria, aan de moderne onderzoekstechnieken, bediend door artsen-specialisten.

Concluderend kan dus gesteld worden dat, niet enkel de openbare instanties preventief optreden, maar dat preventie als een aan de medische praxis essentieel verbonden element kan worden gezien. In het licht van deze overwegingen volgen thans de resultaten van het onderzoek.

3.2.1. Houding van de arts ten aanzien van een aantal geinstitutionaliseerde medisch-preventieve voorzieningen.

Zoals verder moge blijken kan het werkzaam zijn aan een instelling voor preventieve geneeskunde of van openbare hygiène moeilijk als een volwardige parameter gelden voor de preventieve instelling van de arts.

slechts een kwart van de respondenten vervullen immers dergelijk ambt en het geldt dan nog vooral artsen die een orivate praxis hebben of wier praktijk op het platteland of in de lagere sociale woongebieden van de stad is gevestigd. Een dusdanige lage bezetting betekent geenszins dat het belang vàn een preventief optreden door de artsen ondergewar- 
een aantal medisch-preventieve activiteiten die zowel van overheidswege worden geinstitutionaliseerd en verplichtend gesteld, als voor initiatieven die door medisch-wetenschappelijke instellingen of door private artsen worden ondernomen:

- onder de eerste categorie ressorteren o.m. medisch toezicht op jonge arbeiders, medisch schooltoezicht, medische sportonderzoeken (die veelal een experimenteel karakter dragen);

- onder de tweede categorie vernoemen we : bevolkingsonderzoeken over diabetes, tuberculosis, enz..., regelmatig algemeen preventief onderzoek in de private praxis...

Deze naar organisatorisch patroon sterk verschillende preventieve benaderingssystemen worden als samengestelde parameters voor de preventieve instelling van de arts aangewend. Dit kriterium dat op zichzelf reeds van een zekere strengheid getuigt, wordt bovendien nog scherper gesteld door enkel rekening te houden met die uitspraken van de respondenten die wijzen op een maximale belangstelling voor en wardering van de genoemde preventieve systemen als geheel.

War bijna twee derden van de artsen aan dit preventief optreden uiterst veel belang hechten, zijn het toch vooral de oudere artsen van boveh de 50 jaar, meer in het bijzonder die met meer dan 30 jaar praxis die het hoog kwalificeren (APP.III.4.).

Het onderscheid naar specialisme is echter veel duidelijker. Bijna driekwart van de gynaecologen en mondartsen hechten uiterst veel belang aan deze preventieve activiteiten. ook de klinische biologen, de neuropsychiaters, de keel-, neus- en oorspecialisten en oogartsen, verder ook de cardiologen en longartsen drukken zich significant meer uiterst positief uit dan de overige specialisten (App.II.19.).

Slechts $56 \%$ van de huisartsen (14), nauwelijks de helft van de chirurgen en orthopedisten en amper $45 \%$ van de fysiotherapeuten, reumatologen en radio-radiumtherapeuten drukken hun maximale belangstelling wit voor het geheel van de genoemde initiatieven. 
Een detailanalyse, niet opgenomen in deze studie, brengt aan het licht dat vooral bevolkingsonderzoeken in een zeer gunstige bodem vallen bij de grote meerderheid van de artsen. Voor preventieve onderzoeken van jongere mensen is de belangstelling ook opgewekt, doch niet in de brede lagen van het artsenkorps.

3.2.2. Waardering van het preventief element in eigen praxis. Zelfevaluatie.

Uit een factoranalyse (1) op een ruime reeks uitspraken toegepast, kwam een duidelijk bindingspatroon tussen de hierna vermelde statements nar voor.

Var. Lading Uitspraak

1660.73 De specifieke kennis, nodig om aan medico-sociale preventie te doen, is op dit ogenblik nog zo beperkt, dat de tijd van de arts beel beter besteed wordt aan louter curatieve zorg.

$165 \quad 0.68$

In de tegenwoordige praxis is de vraag naar ziektebehandeling zo groot dat nauwelijks enige tijd kan worden besteed om zich met preventie bezig te houden.

1620.63

ziektepreventie is als medische activiteit in de eerste plats eerder een activiteit van openbare gezondheidsdiensten dan van de praktizerende arts.

$240 \quad 0.55$

De vraag naar medische verzorging is tegenwoordig zo groot en de specialisatie voldoende geëvolueerd, dat de huisarts veel beter zijn tijd besteedt aan echt zieke patienten dan aan emationele gevallen.

$173 \quad 0.49$

De patiénten wensen tegenwoordig enkel zo vlug mogelijk van hun ziekte verlost te worden; $z$ in voor een preventief optreden van de arts hebben zij niet, zodat er dan ook geen reden bestaat opdat de arts bij zijn patiënten nadruk zou leggen op het voorkómen van ziekte.

$133 \quad 0.47$

De meerderheid van de patiënten wensen enkel dat de dokter hen afhelpt van hun aandoening en hebben geen nood aan een onderhoud dat los staat van hun onmiddellijke aandoening.

(1) Zie hoofdstuk IV, paragraaf 4.2 . 


\begin{abstract}
Var. Lading Uitsprak
1320.45 De medische praxis is tegenwoordig zo zwar belast dat de arts nauwelijks of geen tijd heeft om met elke patiënt een gesprek te voeren dat geen verband houdt met de ziekte van de patiënt.
\end{abstract}

1540.36 Uitleg geven aan de patient doet over het algemeen meer kwad dan goed.

2410.36 Psychiatrische behandeling is voor de meerderheid der patienten meer een recent luxusartikel dan een werkelijke noodzaak.

1370.34 Voor het behoud van een optimale, vertrouwensvolle arts-patiënt relatie is het wenselijk dat de dokter de beperktheid van zijn therapeutisch kunnen niet veropenbaart aan de patiënt.

overwegend in negatieve vorm opgesteld, schetsen $z i j$ het medico-preventief denken en handelen in de praxis. zij kunnen als volgt worden samengevat.

In de hedendaagse medische praxis wordt het voorko'men van ziekten en aandoeningen gezien als een aangelegenheid die eerder de openbare gezondheidsdiensten aanbelangt dan de praktizerende arts.

Zijn specifieke kennis, nodig om an medico-sociale preventie te doen is immers op dit ogenblik nog zo beperkt, dat hij beter zijn tijd besteed an louter curatieve zorgverlening.

Bovendien wensen de patiënten enkel zo vlug mogelijk van hun ziekte verlost te worden en behoefte aan een onderhoud dat los stat van hun onmiddellijke aandoenign hebben zij niet. $\underline{z} \underline{\operatorname{lt}} \underline{\mathrm{e}} \underline{\mathrm{v}} \underline{\mathrm{L}} \underline{\mathrm{u}} \mathrm{a} \underline{\mathrm{t}} \underline{\mathrm{i}} \mathrm{e}=$

Uit de statements moge voldoende blijken dat, wanneer de arts er zich akkoord mee verklaart, hij de mogelijkheden en de wenselijkheid van de individuele ingreep op preventief gebied secundair stelt, het louter curatief optreden primair. Deze scheidende en prioriteitsverlenende denkwijze heeft zich bij die artsen ontwikkeld uit een samenhang van medico-sociale situaties die zelf gegroeid zijn uit de scherpe 
afbakening van bevoegdheden en bekwamheden van de individuele arts als gevolg van een steeds verder doorgedreven specialisatie (15).

sepalde verondersteltingen omtrent een mogelijke statistische samenhang van de in voorgaande hoofdstukken belichte facetten met de zelfevaluatie van de arts op preventief gebied, worden door de onderzoekingsresultaten niet bevestigd. Het geldt variabelen zoals de leeftijd, de aard van de praxis e.a. Choewel een tendens er op duidt dat oudere artsen meer dan jongere preventief zouden ingesteld zijn). Nochtans treden een drietal duidelijk significante relaties op die, vooral in het licht van de opzet van deze studie, van fundamenteel belang zijn. Het betreft de opinie van de artsen over het specialisatieproces, hun visie over het vraagsuk van de verantwoordelijkheid van de huisarts in dit proces en hun specialistische discipline zelf die gereflecteerd worden in hun al dan niet critische instelling ten aanzien van de preventie. Dat precies deze variabelen een rol spelen, valt te verklaren uit de snelle groei van de medische kennis die op een verhoogde efficientie is geviseerd en har uitdrukking kreeg in een sterke institutionalisering van het gezondheidsbeleid. Het individueel medisch denken blijkt echter niet opgewassen tegen die snelle opmars.

Vooraf dient echter gezegd dat de visie van de plattelandsarts verschilt van die uit de stedelijke centra. Relatief meer plattelandsartsen dan stadsartsen weten zich minder scherp op het preventief vlak te situeren. Uit hoofde van een betere bereikbarheid, kunnen stadsartsen meer formele contacten leggen met $0 . m$. de er voorhanden zijnde instituties (App. III.5.).

Anderzijds is het ook denkbaar dat de plattelandsarts veruit méer patiënten bedient dan de arts uit stedelijke gebieden en, zoals uit a anvullend onderzoek blijkt, vooral patiënten met reele klachten. Hier kan dan als overweging aan toegevoegd worden dat zijn aandacht en zijn tijd hoofdza- 
kelijk op de relatief smalle basis van het louter genezen wordt gedrongen. De kans blijft echter ook bestaan dat het sociaal-psychologische terrein wan de a andoening (nog) niet in de medische cultuur van het platteland is doorgedrongen.

De vraag naar ziektebehandeling aanzien zij dus blijkbaar als voldoende reden om niet a an preventie te doen, tijd voor een gesprek dat losstaat van de onmiddellijke aandoening hebben zij evenmin en in de specialistische infrastructuur vinden $z i j$ een aanvaardbaar excuus voor een passieve instelling terzake. zijn positie die duidelijker tot uiting komt dan die van de stadsarts, stelt de plattelandsarts veilig door de beperktheid van zijn therapeutisch kunnen niet te veropenbaren aan de patient.

Volledigheidshalve kan hier worden aan toegevoegd dat artsen die zowel in de stad als op het platteland hun praxis uitoefenen, zich duidelijk terugvinden op preventief vlak, wat er kan op wijzen dat het stedelijk relatiepatrocn overdrachtelijk werkt op hun plattelandspraxis.

Een meer fundamenteel aspect wordt belicht door de statistische relatie met factoren die de specialisatie in de geneeskunde betreffen (App.III.6.). Zo integreren ruim meer dan een derde van de artsen die een te specialistische opleiding afkeuren en de persoonlijke inzet van de arts op randmedisch gebied voorstaan, als vanzelfsprekend het preventief optreden in de artsenrol. Deze verhouding wordt in verre na niet bereikt door de andere artsen.

Belangrijk zijn ook de verschillen naargelang het beoefend specialisme (APP.II.20.).

Enerzijds stellen we enkele evidenties vast, anderzijds komen we tot een paar opvallende relaties.

Aansluitend bij de vaak alarmerende krantenberichten, medische bijdragen in weekbladen, medische colloquia en congressen die overvloedig de andacht trekken op de nefaste gevolgen van het veel roken en van overdadige mattijden (APPELS, A., 1972), weten zich de cardiologen en pneumologen 
significant meer in de preventieve attitude terug te vinden. Dit sluit aan bij hun zeer positieve beoordeling van de reeks geinstitutionaliseerde preventieve overheidsinitiatieven. verder ligt het ook voor de hand dat kinderartsen zich eveneens duidelijk situeren. Immers, benadrukking van goede verzorging en aangepaste voeding voor zuigeling en kleuter is de primaire opdracht van deze specialist. (zie o.m. de goed georganiseerde raadplegingscentra voor zuigelingen, war de leiding door een kinderarts wordt wargenomen).

curatief en preventief optreden liggen in dit speciatisme sterk verstrengeld, zodat de manifeste positieve zelfevaluatie als evident kan worden beschouwd.

Dat fysiotherapeuten, radio-radiumtherapeuten en reumatologen relatief ook sterk aanwezig zijn, ligt eveneens in de lijn der verwachtingen. Met hun specialistische kennis over de "van nature" heilzame therapie en hun deskundige raad bij het uitvoeren van behandelingen als gymastische oefeningen, massage, electrotherapie, ergotherapeutische begeleiding, enz... voorkomen $z i j$ immers dat een aandoenina tot een chronisch lijden wordt of tot een blijvende invaliditeit zou voeren. zodoende staan zij zeer dicht bij, zo niet middenin het tertiaire vlak van de preventie.

De gevoelige aanwezigheid van de mondartsen bij deze uitdrukkelfjk sterke zelfevaluatie viel eveneens binnen de verwachtingen. De wenselijkheid van vroegtijdige tandheelkundige controle wordt bij de meeste mondartsen wellicht aanvard, doch van organisatorische uitbouw, bijvoorbeeld ter gelegenheid van het verplicht medisch schooltoezicht, is hier te lande nog geen sprake. Het verband tussen voeding en aandoeningen van de mondholte en tandbederf stat vast en de mondarts treedt ook hier, langs raadgevingen in verband met de voeding, preventief op. Elke mondarts zal gewis ook elke "Les in tanden poetsen" aanprijzen.

Dat specialisten als chirurgen, orthopedisten, röntgenspecialisten en anesthesisten zich minder goed op preventief 
Vlak weten te situeren, menen we te moeten toeschrijven aan de technische engheid van hun specialisme. H. a.w. al kan de keuze van de anesthesie (rachie bij 70-jarigen, epidurale anesthesie e.a.) zelf reeds als een vorm van preventic worden aanzien, dan voeleri zij dit niet als dusdanigaan, wel als een a angepaste medisch-technische daad, die blijkbaar geen a ansluiting biedt op een ruimere algemeen preventieve instelling.

In dezelfde gedachtengang menen we hier ook de eerstgenoemden te moeten betrekken. Nochtans is in de orthopedie de vroege behandeling (voornamelijk bij kinderen) van misvormingen van ledematen of ruggegraat heel belangrijk. Immers $z i j$ kunnen een aangeboren handicap vak neutraliseren. In de chirurgie zijn een grote reeks van kleine voorzorgsmatregelen coperatieschort, masker, gummi handschoenen, schrobben van de armen tot aan de ellebogen, jodiumontsmetting van de snijplaats, de autoclaaf en poupinel, enz...) die alle samenvallen met het "curatief" optreden, van uitzonderlijk belang voor het herstel van de patiënt en alle terug te voeren tot de secundaire preventieve sector.

Meer in het bijzonder denken we hier dan ook aan de plastische chirurgie die op uiterst efficiënte wijze voorkomt dat een individu aan de rand van de samenleving blijft (MACGREGOR,F.C., 1960). Deze tertiaire preventie moet dan ook van beide specialismen ontegensprekelijk de aandacht opeisen voor nabehandeling (reactivatie, revalidatie) die de laatste jaren een grote vooruitgang hebben geboekt.

Dat de inherent aan deze specialismen verbonden secundaire en tertiaire preventieve handelingen niet gereflecteerd worden in een sterk positieve zelfevaluatie komt ons dan ook onverwacht voor.

ook de neuropsychiaters en gynaecologen, maar vooral de andere specialisten en de huisartsen weten zich slechts zwak op preventief vlak te situeren. 
Zonder dieper in te gaan op de essentie van het nauwe contact (ook contact met het gezin) en het belang van het gesprek in de huisarts-patiênt relatie of op het kenmerkend onderscheid tussen huisarts en specialist, waar continuiteit in de zorg van eerstgenoemde reeds in se preventie betekent, is de positie van de huisarts ten overstaan van de specialisten in de zelfwardering van deze preventieve inzet dus niet zo bijster gunstig te noemen.

3.3. Wardering van het curatief element in de praxis.

Het onderscheid tussen curatief en preventief optreden van de arts doet, zoals reeds hoger vermeld, artificieel aan. Werd de scheiding tussen beide dan toch doorgevoerd, dan gebeurde dit uit hoofde van de gangbare visie terzake vanwege het artsenkorps.

Afgezien van de enorme verscheidenheid in de benaderingswijze van de patiënt, werd aan de artsen een statement ter beoordeling voorgelegd, waruit blijkt dat, zonder enig voorbehoud te stellen, bijna driekwart der respondenten beamen dat "de meest belangrijke taak van de arts is, de patiënt af te helpen van zijn ziekte of aandoening".

Narmate we met oudere artsen te doen hebben, wordt dit curatief element door steeds meer artsen aldus centrab gesteld. Wellicht werkt het onbehagen dat een patient bij ziek zijn ervart, overdrachtelijk op de eigen gevoelens van de arts naarmate deze ouder wordt en sluit het verwachtingspatroon van de arts des te meer aan bij dat van de patient $($ App. III.7.).

De zeer uitgesproken instelling vinden we verder vooral bij.dermato-venerologen, urologen en mondartsen terug (APD.II.21.), ook wel sterker dan bij de overige specialisten bij chirurgen en orthopedisten. Het minst wardt de statement bijgetreden door anesthesisten en neuropsychiaters (17). Dit beeld sluit echter goed a an bij de leeftijdsstructuur van deze specialisten. De eersten zijn de oudste artsen, de latstgenoemden duidelijk de jongste, zodat we hier, 
voorlopig althans, de leeftijd als een determinerende va$r$ iabele kunnen beschouwen. Enig voorbehoud moet immers gesteld worden daar attitudes nooit eenzijdig worden gedefinieerd, integendeel in een ruimer denkkader moeten worden gezien, dach hierover verder meer.

Behoudens deze personalia differentiëren de antwoorden ook naar een paar andere kenmerken.

zo wordt het louter genezen als een hoogst belangrijke aangelegenheid beschouwd door artsen die het medisch teamwerk zowel naar zijn technische als humane warde weten te appreciëren. Blijkbaar betekent "medisch teamwerk" voor bijna een derde van de artsen (het hoogste aantal) : technische kennis, humane benadering met het doel te genezen (APp.III.8.).

Tenslotte stelten we ook vast dat, artsen die een geaccentueerde specialistische opleiding voorstaan en ook accepteren dat de paramedische uitbouw in de hedendaage geneeskunde de artsen ont last van een persoonlijke inzet terzake, duidelijker het louter genezen central stellen (App. II I. 9. ).

We durven hier dan ook concluderen dat, hoe verder in de medische wereld de specialisatie om zich heen grijpt en hoe meer artsen dit positief beoordelen, des te meer overtuigd zij zijn dat, het louter genezen de opdracht bijuitstek is van de arts.

3.4. Specialisatie en verantwoordelijkheid van de huisarts.

In de medisch-sociologische literatuur wordt herhaaldelijk gewezen op het feit dat uit hoofde van de steeds grotere specialisatie in de geneeskunde en het daarmee gepaard gaande verwijzen, de verantwoordelijkheid van de individuele arts in het gedrang komt.

Deze "waarschuwing" vonden we ook in ons onderzoek terug, maar dan als kritiek geformuleerd door de huisartsen in die zin, dat het verlies van verantwoordelijkheid een 
ongewenst nevenverschijnsel van de specialisatie zou zijn. Met behulo van een terzake gerichte statement, verkrijgen we hierover een duidelijker beeld.

Gesteld werd dat er in de hedendaagse medische praxisvoldoende specialisten zijn, opdat de huisarts niet langer meer een verantwoordelijkheid over een langere termijn zou hoeven te dragen.

Hiermee zijn vooral oudere artsen het eens CADP. I1 I.10.). Naargelang we met jongere artsen te doen hebben, zien deze minder een "afbrokkeling" van de verantwoordelijkheid van de huisarts over een langere termijn.

Uiterst opvallend is het echter, dat bijna alle artsen die de medische opleiding bij voorkeur op de algemene geneeskunde toegespitst wensen te zien en de persoonlijke inzet op randmedisch gebied voorstaan, het er niet mee eens zijn dat de verantwoordelijkheid van de huisarts gat verdunnen (App.III.11.).

ook ten aanzien van de preventieve instelling van de artsen differentieert de visie over deze verschuiving (App. III.12.). Artsen die oordelen dat de verantwoordelijkheid van de huisarts ondanks het toenemend a antal specialisten blijft, zijn bij uitstek preventief ingesteld. Dit komt neer op de overtuiging dat de huisarts de aangewezen man is om, gezien zijn nauwe relaties met het gezin wan het merendeel van zijn patiënten en, derhalve zijn volle integralie in de samenleving, in weerwil van de specialistische uitbouw van de geneeskunde, in te staan voor het behoud van de gezonaheid van zijn patiennten door preventief op te treden. Hij is er en blijfter dan ook verantwoordelijk voor op grond van de overweging dat hij niet enkel de diagnose stelt en de zieke behandelt, mar ook voor de eventuele nazorg instaat, anders gezegd, in tegenstelling tot de specialist, de continuiteit van de zorg verzekert (op zichzelf reeds een vorm van preventie). 
We weten reeds dat vooral oudere artsen in de groeiende specialisatie een vermindering van de verantwoordelijkheid over een langere termijn van de huisarts onderkennen. Deze op iniegroep vinden we thans ook het meest vertegenwoordigd onder de artsen die de centraliteit van het "genezen" vooropstellen (APP.III.13.).

Concluderend zou aldus kunnen gesteld worden dat de oudere artsen enerzijds langs het overdrachtsmechanisme, mar anderzijds langs een gevoel van onvermogen de snelle tred van de specialisatie te volgen, een inkrimping van de verantwoordelijkheid van de huisarts onderkennen en op grond van deze overweging, het "genezen", gezien als meer technische interventie, centraal stellen. Tenslotte worden zij bij voorkeur ook teruggevonden bij de artsen die in een medisch team én de samenbundeling van de technische kennis én de intense samenwerking voor het welzijn van de patient centraal stellen.

Maar hoe staan de onderscheiden specialisten en de huisartsen zelf tegenover deze statement ? (App.II.22.).

Bij deze confrontatie scheiden zich de klinische biologen, de huisartsen en de neuropsychiaters duidelijk af van alle overige specialismen.

Zij vaoral oordelen dat, ondanks toenemende specialisatie, de huisarts zijn verantwoordelijkheid blijft dragen over langere termijn. Een duidelijke meerderheid van hen onderkent aldus de continuiteit van de verstrekte zorg in de huisartsenpraxis. Dat de klinische biologen hier ook figureren,kan best gezien worden in het licht van de extreme situatie warin zij verkeren. Hun "without-patient" praxis in laboratoria isoleert hen van de therapeutische relatie en juist dit kan er hen toe brengen de andere pool beter te percipiëren. Uit eigen onderzoek omtrent de verantwoording van hun keuze tot dit specialisme, is hun strikt wetenschappelijke belangstelling duidelijk af te leiden en zelden zijn de gevallen war deze specialisten verklaren dat hun persoonlijkheid aan de basis van die beslissing ligt of dat de huisartsenpraxis hen minderwardig voorkwam. 
Opvallend is ook dat bijna de helft van de röntgenspecialisten (ook uitgesproken technici) die continuiteit in de huisartsenpraxis onderkennen. Hier kan wellicht deels ook een graad van isolement hun instelling conditioneren.

Bij de overige specialisten, die trouwens in veel beperktere mate de permanente verantwoordelijkheid van de huisarts voorhouden, vallen vooral de keel-, neus- en oorspecialisten, oogartsen, dermato-venerologen, urologen, chirurgen en orthopedisten op. Zij zijn duidelijk technische specialismen die hun eigen interventie als het ware loshaken van de ziekte als dynamisch gegeven.

$$
\text { Geldt dit ook voor de gynaecologen, warvan nauwe- }
$$
lijks tweevijfden de continuitejt in de huisartsenpraxis onderkennen, dan kan enerzijds de twijfel daaromtrent en anderzijds de zwakke aanwezigheid van de kinderartsen onverwacht voorkomen. Doch, voor bejde laatstgenoemde disciplines heeft de bijzonderheid van de categorieën van de patiënten ("kliënten") ongetwijfeld hun evaluatie van deze statement bepald. 


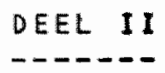

de zelfevaluatie van de arts 
HOOFDSTUK IV. ZELFEVALUATIE VAN DE ARTS IN EEN AANTAL ROLCOMPONENTEN.

4.1. Inleiding.

Enkel specifiek onderzoek naar de verantwoordelijkheden in het artsenberoep kan een antwoord verstrekken op de hiervoor gestelde vragen.

We menen evenwel dat in het raam van deze verhandeling een beperkt onderzoek naar de zelfevaluatie van de artsen in een aantal rolcomponenten reeds enige verduidelijking kan brengen.

Door "verantwoordelijkheden" wordt niet het juridisch begrip bedoeld, dat trouwens stilaan verdrongen wordt door het begrip "aansprakelijkheid" dat wél een juridische betekenis heeft. In termen van ons onderzoek duidt het begrip op een gevoel, een "zin" voor verantwoordelijkheid en heeft zodanig een sociologische betekenis.

Deze verantwoordelijkheid kan worden omschreven op grond van de sterke hechting vooral in het medisch beroep a an gemeenschappelijke warden. D.w.z. de deelnemers hebben gemeenschappelijke gevoelens ter staving van het erin heersende wardepatroon. Daar deze hechting aan gemeenschappelijke warden de onmiddellijke bevrediginn van de noden van de deelnemers kan bewerkstelligen, is er ook een moreel aspect aan verbonden in die zin, dat de conformiteit in zekere mate ook de verantwoordelijkheden van de deelnemers in de brede sociale context warvan zij deel uitmaken, bepalt.

Het ligt dan ook voor de hand dat het specifieke brandpunt van de verantwoordelijkheid de gemeenschap is en dat de gevoelens, dfe de gemeenschappelijke warden ondersteunen, niet gewoonweg inherent $z i j n$ a an die groep, maar worden aangeleerd en verworven.

Als dusdanig zijn derqelijke gevoelens, wardehoudingen, deel van de structuren van het persoonlijkheidssysteem van de deelnemers. Verantwoordelijkheid kan in dit sociologisch 
kader dan worden geformuleerd als een geheel van wardehoudingen die artsen verworven hebben en op grond derwelke zij verondersteld worden alles te doen wat mogelijk en wenselijk is om de gezondheid te handhaven en ziekte te voorkomen, zor der dat zij, bijeventueel falen, aansprakelijk kunnen worde gesteld.

Ging onze aandacht totnogtoe hoofdzakelijk naar ee aantal opinies van de artsen, dan wordt thans gepoogd enkele van de wardehoudingen in de rolvervulling van de artsen te identificeren.

Te dien einde werd aan de artsen een reeks van 46 statements ter beoordeling voorgelead. Deze statements zijn constructies die uit een brefe literaturverkenning tot stan zijn gekomen. D.w.z. dat de literatuur zelden rechtstreeks toegang verleent tot identificatie van de in onderhavio ondes zaek geformuleerde statements, mar dat vak zeer literair be spiegelende beschrijuingen elementen bevatten, die ons voorkwamen als deelfacetten van de artsenrol.

Het is op basis van veelvuldige, ocenschijnlijk zee gedifferentieerde en eerder toevallige auteursuitlatingen dat we tot meer precieze formuleringen konden komen, die aangrijpingspunten bleken te zijn voor een, zo niet volledige, dan toch meer gestructureerde benadering van de rolconceptie van de artsen.

Het hierbij door hen ingenomen standpunt betekent meteen dat zij zichzelf in deze onderscheiden wardehoudinger hebben geêvalueerd.

Door middel van de multivariate techniek van de factoranalyse vonden we vier van elkaar onafhankelijke factoren, die we menen een uitdrukking te zijn van die diepere warden.

Dergelijke benadering van de artsenrol biedt ons de mogelijkheid na te gaan in welke mate de beoefenaar a an de sooiaal-psychologische eis van zijn rolvervullina beantwoordt. Wat de arts doet of niet doet hangt immers niet enkel af van zijn wetenschappelijke kennis of van de professione 
le ethiek, vastgelegd in een stel regels, maar ook van de verwachtingen van de leden van de aemeenschap en van de verantwoordelijkheden die hem worden toegewezen (17).

De medische praxis omvat dus niet enkel de toepassing van een bepaalde (nog vak beperkte) biologische kennis, mar ook van een oriëntatie nar factoren die niet direct met die kennis verband houden, m. a.w. ook de toepassing van een niet onaanzienlijke dosis van sociale en psychologische kennis.

Menselijke interactie is immers een sociaal-psychologisch structureel geheel warover de arts verondersteld wordt een zekere kennis te hebben. "Usually, we perceive... in noncumulative terms", zegt J.Romano (1960) en stelt dan de vraa of dit ligt aan de onwetendheid of a an de beperkte informatie over wat werd aangeleerd en opgenomen in de geest of geaccumuleerd op het gebied van de psychologie en de sociale wetenschappen in verband met de dokter-patiënt relatie, de psycho-sociale kant van de ziekte of de kennis van de zieke zelf en zijn familie.

In elk geval mag worden verondersteld dat de huisarts bijvoorbeeld, veel beter dan om het even welke specialist de interfamiliale communicatie en het specifieke gedragspatroon intuitief kan percipiëren, wat hem helpt zijn artsenrol te oriënteren naar deze vaak ingewikkelde verscheidenheid. De totale mens biedt zich immers bij de arts a an met een probleem dat. nast het louter somatische, medegevolg kan zijn van psychische of sociale omstandigheden (DROGENDIJK,A.C., 9965). Het is dan ook de taak van de arts, het oorspronkelijk probleem, dat aan de a angeboden ziekte ten grondslag ligt, te vinden. D.w.z. dat geen diagnose kan gesteld worden zonder enige kennis van de persoonlijkheid of van het woon-, werk- en leefmilieu van de patiënt, wat inhoudt dat de arts hierover moet informeren of geinformeerd worden. Die informatie verkrijaen huisartsen en specialisten op verschillende wijze. De huisarts die ten huize van de patient komt, krijgt contact met het sociaal milieu van de patient en kan langs loutere observatie om, informatip krijaen die zoveel duidelijker is dan diegene die wit het gebruikelijk 
gesprek noet blijken.

ook tussen specialismen onderling kan het relatiepatroon sterk verschillend zijn, maar of er zo technische specia lismen zijn dat dergelijke informatie volstrekt overbodig is, durven we betwijtelen. De moejlijkheid echter liat in het achterhalen van de graad van noodwendigheid in deze. Gesteld mag worden dat, hoe miniem die eis ook moge zijn, het ontkennen va deze een remmende invloed kan hebben op het herstel van de pa $t i e ̂ n t$.

$$
\text { De mate warin zich dit relatiepatroon in de onder- }
$$
scheiden specialismen laat onderkennen, wordt thans in de hier navolgende hoofdstukken behandeld.

4.2. Defactoranalyse (App.I.20)

Door toepassing van de factoranalyse op 46 variabeler die betrekking hebben op de zelfevaluatie van de arts inzake $z$ jjn preventieve instelling en op een aantal wardehoudingen in zijn rolvervulling, werden vijf lineaire combinaties van variabelen gevormd met een verklaarde variantie van $31 \%$. (App.IV)

Aangezien factor I I specifiek betrekking heeft op de zelfevaluatie van de arts op het preventief vlak van zijn praxi en deze als zijnsgebonden a an elke praxis kan worden beschouwd, werd aan deze factor reeds in hoofdstuk 3.?.2. de nodige a andacht verleend.

De overige vier factoren (I, III, IV en $V$ ) zijn een duidelijke uitdrukking van de zelfconceptie van de arts over een aantal verantwoordelijkheden of wardehoudingen in de praxi:

In de hoofdstukken hierna worden deze wardehoudingen in relatie gebracht met de berekende factorscores van de artsen. De gemiddelden en standaardafwijkingen van artsencategorieen op een aantal kenmerken worden alsdan op hun significantie getoetst. 
4.3. De social-integratieve rolcomponent.

4.3.1. Inleiding.

Uit de factoranalyse blijkt dat op de eerste factor negen variabelen hoog laden.

Var. Lading Uitspraak

1290.56 Voor het herstel van een patient is het witerst belangrijk...absoluut onbelangrijk... dat de arts het gezin van de patient betrekt in het contact tussen hem en zijn patient.

122 0.54 In zijn dagelijkse praktijk moet de arts enige tijd voorzien on met elke patiěnt die hij ontvangt of bezoekt een kort gesprek te voeren dat niet noodzakelijk in onniddellijk verband staat met de klachten van de patiënt.

De bevolking moet tot een verstandige zienswijze worden opgevoed ten aanzien van de mogelijkheden en grenzen van de doktershulp.

Voor een adequate behandeling van de patiënt is het uiterst belangrijk...absoluut onbelangrijk... dat de arts de emotionele weerklank kent van de ziekte van de patiënt op diens gezin.

$136 \quad 0.47$

Om tot een doeltreffende behandeling van de patiënt te kunnen overgaan, moet de verhouding tussen arts en patiënt vlot verlopen.

$145 \quad 0.46$ De werkzamheid van heel wat geneesmiddelen en behandelingsmethoden wordt eerder gestimuleerd door het vertrouwen van de patiënt in de arts die ze voorschrijft of toedient, dan door het geloof van de patiënt in de objectieve werkzamheid van de bewuste geneesmiddelen en behandelingen zelf. 
Var. Lading Uitsprak

1470.44 Dewerkzamheid van heel wat geneesmiddelen en behandelingsmethoden wordt eerder bepaald door het vertrouwen van de patient in de arts dan door de objective werkzamheid van die middelen zelt.

$123 \quad 0.40$ Ernstige familiale moeitijkheden die nochtans van rechtswege geen tegemoetkoming voorzien, zouden voor de arts eem voldoende reden moeten zijn om aan een "patient" een medisch attest ter excuus at te leveren.

125 0.39 Wanneer de arts een patiënt ontvangt, waarvan hij vermoedt dat bepalde familiale omstandigheden (bvb. het samenwonen met schoonouders) de mogelijke oorzaak zijn van eventueel psychosomatische a andoeningen en de patiënt zelt hier geen verband legt, moet hij de patiënt ooenlijk op die toestand wjzen.

De megen uitsprakef hebben betrekkina op het complementair karakter van de rolvervullingen in de arts-patient relatie. Dit wil zeggen dat in de samenleving voor al die delen van die samenleving een innerlijke tendens bestat zich in het geheel functioneel te integreren.

In de onderhavige rolcomponent komt dit o.m. tot uitdrukking in de uitspraak (hoogste lading: 0.56) dat, het voor het herstel van de pat ênt belanquijk is dat de arts het gezin van de patiënt betrekt in het contact tussen hem en de zieke. Immers, een lichamelijk ongemak ervaren, wekt bij de patient een gevoel van ongerustheid op. Er treedt een moejlijk te identificeren a apassing op aan zijn sociale omgeving. oit breekpunt komt in de regel in eerste instantie tot uiting in zijn normale gezinsgerichte rolvervulling.

Gezien het complementair karakter van rolvervullingen zal een adequate behandeling van de patiënt aldus slechts magelijk zijn, wanneer de arts de emotionele weerklank kent van 
de ziekte van de patiënt op diens gezin cuitspraak met lading 0.50 ).

In de arts-patient relatie veronderstelt de rol van de arts niet enkel die van de patiënt - en vice versa - mar de rol van de patiënt veronderstelt ook de rol van het gezin in het ziakteverschijnsel en omgekeerd. De arts dient ook hier weer rekening mee te houden. Wederkerigheid in deze relatie ligt voor de hand.

Deze wederzijdse erkenning van de onderscheiden rollen die trouwens voor elke geleding in de samenleving geldt, is een onmiskenbare voorwarde om, ook in het kleinere systeem van de medische praxis een optimale verhouding mogelijk te maken. Wederzijdse erkenning houdt dan ook in dat de arts de omgeving van de zieke verkent. Dit kan hij langs een gesprek dat dus niet noodzakelijk in onmiddellijk verband stat met de klachten (uitspraak met lading 0.54 ).

Dit sociaal-integratief functioneel systeem berust op de menselijke persoonlijkheid. Elk individuzit gevat in een variërend aantal institutionele contexten en streeft hierin naar erkenning, waruit volgt dat eenzelfde streven naar welzijn een zelfde normenstelsel veronderstelt. De uitspraak (lading 0.53 ) dat de bevolking tot een verstandige zienswijze t.a.v. de mogelijkheden en grenzen van de doktershulp moet worden opgevoed, sluit hier duidelijk bij aan.

In welke mate $z i c h$ de respondenten in deze rolcomponent weten te identificeren, blijkt uit de hiernavolgende resultaten van het onderzoek.

4.3.2. Resultaten van het onderzoek.

Bij de beoordeling van deze component weten zich bijna de helft der respondenten sociaal-integratief ingesteld, warbij de leeftijd van de arts enigszins een rol blijkt te spelen. We zouden het zo kunnen formuleren dat de jongere arts zich niet zo gemakkelijk in deze component weet te situeren omdat het hem niet enkel op het gebied van de medische kennis aan ervaring ontbreekt, mar ook in het "leven". M.a.w. te vlug 
neemt hij misschien een beslissing of grijot hij naar de nieusste onderzoeksmethode ten koste van een voldoende directe observatie van de omgevingsfactoren, wat zoals we vroeger zagen, door oudere artsen als een routine-zaak wordt opgevat.

Het kan dan ook als normaal worden aanvard dat, oudere artsen zich relatief meer dan hun jongere collega's in de sociaal-integratieve rolcomoonent terugvinden en wel in die 2 in dat, hoe meer ervaring een arts heeft, en in de regel analoog daarmee, hoe ouder hij is, des te meer hij bedachtzaam zal zijn dat hij rekening dient te houden met de nevenverschijnselen die de marginal sociale positie van de patiënt op zijn directe ongeving kan sorteren. Zonder vreende elementen in de arts-patiënt relatie een kans te geven, is hij wellicht ook meer dan zijn jongere collega's de patiënt-geöriënteerde dokter die vertrouwen wekt langs zijn grotere maturiteit. Het onderscheid tussen jongere en oudere artsen in deze evaluatie valt echter vooral sterk op bij de extreme leeftijdscategorieen.

Deze overwegingen sluiten aan bij de evaluatie die oudere artsen aan hun academische opleiding hechten. Hoewel niet le duidelijk witgesproken, blijken de artsen die hun opleiding in har geheel adequat vonden, zich sterk in de sociaal-integratieve component terug te vinden. Nu stellen we vast dat het juist dié personen zijn die oordelen dat hun opleiding adequat is geweest, ook de artsen zijn die zich relatief meer dan de anderen met deze component het best weten te vereenzelvigen, wat er kan op duiden dat de oudere artsen reeds van zeer vroeg en dank zij een aangepaste opleiding, het belang van deze component onbewust hebben aangevoeld.

De zelfevaluatie verschilt ook duidelijk significant naargelang de wardering die de arts voor de samenwerking in het medisch-teamwerk weet op te brengen. Deze vaststelling sluit noed aan bij een specifiek anderzoek terzake over medisch-teamwerk van E. G. DOHERTY En J.HARRY (1976).

vooral de artsen die in het medisch team zowel de samenbundeling van de technische kennis als de samenwerking voor het 
welzijn van de patiënt als uiterst belangrijk evalueren, weten zich het best als sociaal-integratief ingestelde artsen te situeren. Hun zin voor een technisch-humane benadering van de patiënt reflecteert hun zelfevaluatie op het sociaal-integratieve $\checkmark$ lak van de therapeutische relatie. Uit a nuullend onderzoek, niet opgenomen in deze studie, blijkt hen ook een begrijpende houding als bijkomende eigenschap te kunnen worden toegekend.

Met het beoefend specialisme werd geen statistisch significante relatie gevonden, hoewel de duidelijk hogere vertegenwoordiging van de neuro-psychiater bij de uiterst positief ingestelde artsen tot enige overweging uitnodigt (App.II.23).

Hoewel deze specialisten vooral tot de jongere generatie van het artsenkorps behoren en deze zoals hierboven gezien, zich minder dan de oudere artsen in deze component terugvinden, treffen we er de neuro-psychiater duidelijk meer aan. Dit wijst er op dat de neuro-psychiaters niet of minder in deze categorie van jongere artsen gevat zitten, maar zich wel degelijk uit hoofde van hun specialisme in een uitzonderingspositie plaatsen bij hun zelfevaluatie in deze component.

4.4. De informatieve rolcomponent.

4.4.1. Inleiding.

Bij de tweede combinatie van samenhangende variabelen zijn tien uitspraken betrokken met hoge lading (factor III in $A p P$. IV).

Var. Lading Uitspraak

1510.60 Wanneer de arts over het warom van de voorgestelde therapie uitleg verstrekt, dan doet hij dit omdat dan eerst samenwerking mogelijk is.

1630.56 Preventie veronderstelt alleszins een zekere kennis vanwege de arts over de houding van de patient ten aanzien van ziekte en gezondheid en dit is een factor die in de aeneeskundige praxis nog onbestaande is. 


\begin{tabular}{|c|c|c|}
\hline Var. & Lading & Uitspraak \\
\hline 143 & 0.55 & $\begin{array}{l}\text { Om een nauwe samenwerking vanwege de patiënt } \\
\text { te bekomen, moet de arts erover waken dat de } \\
\text { patient volledig begrijpt wat de geneesheer } \\
\text { doet. }\end{array}$ \\
\hline 150 & 0.49 & $\begin{array}{l}\text { Wanneer de arts over het warom van de voor- } \\
\text { gestelde therapie uit leg verstrekt, doet hij } \\
\text { dit omdat de patiënt er recht op heeft. }\end{array}$ \\
\hline 152 & 0.45 & $\begin{array}{l}\text { Wanneer de arts over het warom van de voor- } \\
\text { gestelde therapie uitleg verstrekt, doet hij } \\
\text { dit om een nieuwe of ergere aandoening te } \\
\text { voorkomen. }\end{array}$ \\
\hline 144 & 0.44 & $\begin{array}{l}\text { Voor een adequate behandeling van de patiênt } \\
\text { is het over het algemeen wenselijk dat de arts } \\
\text { de patiënt onttrekt aan de invloed van zijn } \\
\text { gezin. }\end{array}$ \\
\hline 153 & 0.36 & $\begin{array}{l}\text { De meerderheid van de patienten brengen de } \\
\text { dokter door hun openheid in het gesprek op } \\
\text { een spoor dat niet zuiver medisch is, mar } \\
\text { dat nuttig is bij het stellen van een diagnose. }\end{array}$ \\
\hline 126 & 0.33 & $\begin{array}{l}\text { over het algemeen is het beter dat de arts } \\
\text { een door een patient vermeende, ernstige ziek- } \\
\text { te afwentelt naar een andere, minder ernstige } \\
\text { ziekte, dan het de patient duidelijk te maken } \\
\text { dat hij niets mankeert. }\end{array}$ \\
\hline 161 & 0.32 & $\begin{array}{l}\text { over het algemeen is het aangewezen dat de arts } \\
\text { eventueel op het einde van het gesprek aan } \\
\text { zijn patiënt volgende vraag stelt: "Wat ver- } \\
\text { wacht u nu van mij?". }\end{array}$ \\
\hline 154 & 0.39 & $\begin{array}{l}\text { Uitleg geven aan de patiënt doet over het al- } \\
\text { gemeen meer kwaad dan goed. }\end{array}$ \\
\hline
\end{tabular}


Deze factor duidt op het belang in de arts-patient relatie van de informatieverstrekking.

Deze is een onontbeerlijke voorwarde tot samemwerking (statement met lading 0.60). In veel ziektegevallen is het de angewezen weg on de therapeutische relatie optimal te laten functioneren en de patient te laten a nvoelen dat de arts werkelijk met zijn welzijn bekommerd is.

Bij bepaalde a andoeningen cbvb. hartziekten, diabetes), mar ook op het stuk van de preventieve geneeskunde is informatie verstrekken uiterst belangrijk. Er mag dan ook verondersteld worden dat de arts een zekere kennis heeft over de houding van de patiënt ten aanzien van ziekte en gezondheid. In de medische praxis is deze visie echter nog niet ingeburgerd (lading 0.56). Anderzijds moet gesteld worden dat, ten einde samenwerking in de hand te werken ook bij de patient een zekere kennis aanwezig is of beter dat hij precies begrijpt wat de dokter doet (lading 0.55). Hier moet de arts voor instaan, want in het licht van de subjectieve beleving van de patient van zijn ziekte, verlangt deze wanneer hij zich met zijn klachten aanbiedt, meteen ook verlost te worden van een bepald angstgevoelen en dit kan niet geschieden zonder een zo volledig mogelijke, als wenselijke uitleg door de arts.

Discussie is hier echter steeds bestaande wanneer de arts duidelijk moet gaan onderscheiden of en wanneer hij de zieke volledige uitleg kan, durft en moet verstrekken.

ook over het warom van de informatieverstrekking wordt vaak gediscussieerd. Immers, uitleg verstrekken kan, zoals reeds vermeld,psycholagisch goed zijn omdat het de patient coobperatief instelt, mar ook omdat de patiënt er recht op heeft (18) clading 0.49 ) of omwille van het preventieve effect ervan (lading 0.45$)$.

In elk geval zijn informatie en gesprek in de artspatient relatie zijnsgebonden. We benadrukken hier evenwel dat in deze rolcomponent enkel het psycho-therapeutisch effect van informatie en communicatie wordt bedoeld en distantie wordt ge- 
nomen van het begrippenpar "psycho-therapeutisch gesprek" dat een andere inhoud heeft.

Met betrekking tot deze rolcomponent zijn een aantal signifirante relaties naar voren getreden. We besoreken ze hierna.

4.4.2. Fesultaten van het onderzoek.

Loals bij de social-integratieve component stellen we in de zelfevaluatie van de informatieve component een analogie vast tussen leeftijd en "wardering van de academische opleiding". Naarmate de artsen tot een oudere leeftijcscategore gaan behoren of ten aanzien van de genoten academische oplaiding positief zijn ingesteld,ook wat de menselijke contacten betreft, strjgt ook op zeer duidelijke wijze het percentage van hen die zich in de informatieve component witdrukkelijk weten te situeren. Ook hier zal hun ervaring of de contactrijke medische opleiding die zij mochten genieten, hen het gevoel hebben bijgcbracht dat aandacht voor het informatieve aspect in de therapeulische siluatie niet kan worden genegeerd. Al heeft the gespres niet steeds een therapeutisch effect, dan toch biedt het de art: valk de gelegenheid allerlei problemat ische toestanden te vinden die (niet steeds noodzakeljjk)tot klachten hebben geleid, maar die darom niet per se een weerave zijn van de reële aandoening. Ervaren artsen hebben wellicht ook dit voordeel dat dergelijke patiënten zich gemakkelijker ontsluiten voor hen.

Deze informatieve qeärienteerdheid blijkt ook meer op te treden bij artsen die hun praxis het langst of steeds in stedelijke gebieden witoefenen en ook bij artsen die in stedelijke woongebieden van de hogere sociale lagen of van én hogere én hoger gemengde sociale lagen hun beroep uitoefenen. Meer dan de plattelandsabtsen tie in de socjaal lagere woongebiedan van steden hun praxis hebben, worden zij wellicht aangezocht tot het verstrekken van informatie of tot het voeren van een gesprek over persoonlijke moeilijkheden, wartoe stadsbewoners in hun social-hoger woonomgeving minder kanser hebben. De arts in 
deze gebieden is dan wellicht de figuur warmee dergetijk contact wél mogelijk is.

Een differentiële visie over deze rolcomponent blijkt ook geconditioneerd door het verschil in wardering van de doelstrevingen bij medisch teamwerk.

Informatie verstrekken omvat immers naast het inlichten van de patiënt, voor een goed deel het geven van voorlichting met het doel de patient, mar ook zijn omgeving, tot een gedrag te brengen dat gunstig is voor zijn gezondheid. Zonder dieper in te gaan op de brede wazier warop dit voorlichtend optreden van de arts van toepassing kan zijn, ligt het voor de hand dat de arts hierbij een reeks verantwoordelijkheden draagt die in elke therapeutische relatie als een continuum optreden. zo kan bij medisch teamwerk gesteld worden dat de verantwoordelijkheden als het ware aan een verdunningsproces onderhevig zijn, daar alle deelnemers er bij betrokken worden.

We stellen dan vast dat artsen die de gedeelde verantwoordelijkheid bij teamwerk hoog aanschrijven, zich duidelijker op het informatieve vlak situeren dan de anderen en verder, dat zij die zowel de technische inbreng als het welzijn van de patiënt in dat teamwerk zeer belangrijk achten, zjch eveneens duidelijk op het informatieve vlak van de praxis teruqvinden. Men zou ze "patiënt-gerichte" artsen kunnen noemen, in tegenstelling tot de "science-georiënteerden" die zich niet weten te situeren op het informatieve vlak en bij voorkeur artsen zijn die in medisch teamwerk enkel de gezamenlijke inbreng van de technische kennis central stellen. Het minst informatief ingestelden zijn de artsen die geen enkele doelstreving bij medisch teamwerk een centrale plaats toekennen.. Moqen we hen dan rekenen tot de voor de samenleving "anonieme doctor-oriented" artsen, die enkel voor zichzelf bestaan?

vervolgens zijn de artsen die veel warrering opbrengen voor de geinstitutionaliseerde preventieve initiatieven, meteen personen die zich duidelijk in de informatieve component weten te platsen, mar een heel wat belangrijker aanwijsbare statistische significante relatie betreft het specialisme CAop. II. 24). 
Weten zich bij uitstek zeer uitdrukkelijk in onderhavige rolcomponent te situeren: de cardiologen, pneumologen, mondartsen en $k L i n i s c h e$ biologen.

Is het verstrekken van informatie aan de patiënt als redelijke verwachting van deze, een in de regel ntet alledaags gebeuren in het dokterscabinet, dan mag het, vooral wat de cardiologen en longartsen betreft, belangrijk heten dat deze specialisten aan de top figureren in de informatieve zelfevaluatie $(19)$.

Draagt bovendien de verstrekte informatie, hetzij een orienterend, hetzij een geruststellend karakter of bevredigt zij "tout court", dan toch zal in deze specialismen vooral de inhoud van de verstrekte informatie de a andacht trekken. Immers uit de stelselmatig van overheidswege gestimuleerde bevolkingsonderzoeken (intradermo-reactie onderzoek, röntgenoscopie) en populariserend medische bijdragen der massamedia over hartziekten (20), mag met voldoende zekerheid worden aangenomen dat de meerderheid der patiënten zich niet enkel met de meeste belangstelling, mar vooral met een aanzienlijke onzekerheid bij deze specialisten aanmelden. Vitale organen staan immers op het spel, warbij het vertrouwen, zoniet het geloof, dat de medische wetenschap voldoende is gevorderd, het moet halen op het gevoel van onzekerheid dat voortspruit wit de onwetendheid omtrent de kansen van herstel.

Nu is het wel zo dat in deze specialismen de arts valk, zowel met vermeende als met ernstige aandoeningen geconfronteerd wordt en in het latste geval stat het buiten alle twijfel dat hij toch voor moeilijke opgaven komt te staan.

De voorlichting van overheidswege over de hier betrokken aandoeningen kunnen hem echter als voldoende warborg vódrkomen dat een adequate d.w.z. omzichtige informatie terzake, aan de patiënt richting en inhoud geeft aan zijn nieuwe situatie. M.a.w. het onzekerheidsgevoel wordt aan banden gelegd door een betere aanpassing aan de nieuwe omstandigheden. Herinneren we hier ook aan de duidelijk preventieve instelling van deze 
specialisten. Door deze nieuwe gedragslijn van de patient te bewerkstelligen, worden ook eventuele ongewenste emotionele invloeden (aandikken van de angst) van het gezin beter geweerd.

voor de klinische biologen, die hier ook beduidend sterker dan de andere specialisten vertegenwoordigd zijn, menen we dat hun duidelijke zelfevaluatie rechtstreeks te koppelen is aan de techniciteit van hun vak en naar essentie moeilijk op één lijn kan worden geplatst met de eigenwardering terzake van andere, niet technische specialismen. Kan enkel meer speuifiek onderzoek hierop een duidelijk antwoord verstrekken, dan toch menen we dat, analoog met hun randmedische interesses, een identieke verklaring kan gelden met name, dat hun geisoleerdheid zelve, hun technische afzondering als het ware, een nieuwsgierige drang naar - zoals eigen aanvullend onderzoek uitwijst algemeen medische literatuur oproept warin zij de zieke als gehele persoon herontdekken (21).

Voor de hoge vertegenwoordiging van de mondartsen is een direct a anknopingspunt voor de informatieve zelfevaluatie eveneens moeilijk aanwijsbaar. Evenwel kan, zoals bij de cardiologen en pneumologen, natuurlijk onrechtstreeks, de zeer duidelijke preventieve instelling van deze specialisten worden ingeroepen, warbij hun $z$ in voor het verstrekken van voorlichting aansluit bij hun onderhavige zin voor het verstrekken van inlichting, zij deze nu een uitdrukking van hun aewilligheid de nogal verspreide nieuwsgierigheid terzake van de patient te bevredigen of zij het een middel om de patient op een duidelijke wijze te overtuigen dat ernstige pijnklachten niet steeds een voorbode zijn van ernstige afwijkingen en/of ingrjjpende behandelingen.

Bij de matig positief ingestelde artsen vinden we nog zeer duidelijk een groter aantal anesthesisten terug. De positieve zelfevaluatie van deze, in fejte dienstverlenende specialist heeft o. i. een beperkte inhoud. Centraal staat voor hem het probleem van de angstige patiënt, die zijn bewustzijn tijdelijk prijs moet geven. De beperkte tijd warover deze specia- 
list in de regel beschikt (of die hij slechts voorziet) om contact op te nemen met de patient, moet hij benutten om het begrijpelijk angstgevoelen te milderen of op te heffen. Zijn informatieve inzet komt aldus neer op een geestelijk begeleidende communicatie met de patiënt, waarbij hij in verstaanbare taal zijn technische ingreep uitlegt. Zodoende draagt de informatieve zelfevaluatie van deze technicus een quasi uitsluitend geruststellend karakter.

ook de internisten en gastro-enterologen komen hier nog aanzienlijk aan bod, doch hun "matig positieve" zelfwaardering kan eerder verklaard worden uit de moeilijkheidsgraad van hun specialjsme, m.a.w. door de graad van eigen onzekerheden warmee deze specialisten vaak bij diagnose en therapie worden geconfronteerd. Hierbij kan worden overwogen of het wel wenselijk is de patiënt met deze onzekerheden bekend te maken, daar dergelijke openheid de kans tot emotioneel engagement van de arts in zijn relatie tot de patiënt kan vergroten.

Vooral chirurgen en orthopedisten zijn artsen die zich slechts $z$ wak in de informatieve rolcomponent identificeren. Deze artsen werken in hoofdzaak in ziekenhuisverband en daar voeren zij,als strikt technische en weinig contextbehoevende specialisten, de hen vertrouwde opdrachten uit en behoudens de technische relatie, bestaan er mogelijks minder contacten met de patiënt, warin de informatieve rolcomponent a an bod zou kunnen komen.

Ook de fysiotherapeuten, reumatologen en radio-radiumtherapeuten weten zich moeilijk op dit vlak te situeren. Voor hen kan worden aangevoerd dat, eens zij hun zeer belangrijke preventieve rol hebben gespeeld, de informatie over de te volgen therapie doorspelen aan andere medici en ook paramedici.

De gynaecologen/verloskundigen erkennen $z i c h$ wel iets duidelijker in deze rolcomponent, mar hun positie valt toch buiten ons verwachtingspatroon daar, behoudens de zorg om de bevalling zelf, de activiteiten van de verloskundige vooral in de prenatale periode te situeren vallen, war informatie niet enkel op het somatische, maar ook en misschien vooral op het 
psychische vlak van a anzienlijk belang is. Van kraamzorg maken we hier geen gewag daar deze ten volle binnen de bevoegdheden van de vroedvrouw valt. of zijn sommige gynaecologen/ verloskundigen de mening toegedaan dat te veel informatie verstrekken aan vrouwelijke patiënten ongewenste paniektoestanden kan creëren? Verder onderzoek zou ook hier wellicht een antwoord kunnen op geven.

Enige aandacht vraagt ook de positie van de huisartsen, warvan zich niet eens de helft met de informatieve component identificeren. Drukt de intense bezetting van hun praxis de informatieve inzet omlaag? of is zijn beperkte aanwezigheid te koppelen a $z i j n$ kritiek op de medische opleiding, waar hij o.m. het gebrek aanklaagt van een opleiding over mentaliteit en psychologie van de patiënt? Werd of wordt de opleiding van de huisarts voor zijn matschappelijke rol nog verwarloosd? ontbreekt het hem aan diagnostische aandacht? Tenslotte kan ook moeilijk worden voorbijgegaan aan de eerder geringe vertegenwoordiging van de neuro-psychiaters . Vooral in dit specialisme kon een top-positie worden verwacht, zodat deze belangrijke informatieve rolcomponent in zekere zin ondergewaardeerd blijkt te worden. Enige reserve is hier echter geboden daar in dit specialisme, niet enkel ten aanzien van de patiënt, maar vaak ten aanzien van andere specialisten, waaronder ook de huisarts, een grotere discretie moet worden aan de dag gelegd.

of beoogt deze specialist met de uitheg die hij aan de patiënt verstrekt, vooral een therapeutisch effect? Is dit soms een reactie op en mentaliteit die de gehele samenleving kenmerkt en zich ook in de medische sector manifesteert, met name, de eis tot tastbare interventie en tot direct meetbare resultaten, wat nu eenmal niet behoort of kan behoren tot de geboden behandelingsmethodiek in dit specialisme bij complexe neurologische en psychiatrische ziektetoestanden? Is het omwille van de gevoeligheid voor lekenkritiek dat deze specialist in de informatieve rolcomponent "slechts" een middenpositie bekleedt? 
Voor de zieke hoort de arts immers op zichtbare of direct voelbare wije tussen te komen en dit doet de psychiater niet. Heestal doet hij beroep op de zelfuerkzaametid van de patient en dit wekt bij deze de indruk dat zijn behandelende arts zelf niet actief is.

4.5. De social-opvoedende rolcomponent.

4.5.1. Inleiding.

In deze derde combinatie van samenhangende uitspraken (factor IV) worden acht variabelen met hoge lading betrokken. Var. Lading Uitsprak

155 0.53 Het publiceren in tal van dag- en weekbladen van medische artikels doet over het algemeen meer kwad dan goed.

157

0.44

Het staat de arts vrij een patient die een ziekte voorwendt, al dan niet uitleg te geven over zijn weigering een medisch attest af te leveren.

158 Wanneer een "patiënt" openlijk bekent dat hij niet ziek is, maar wegens zekere moeilijkheden om een medisch voorschrift verzoekt, is de arts niet verplicht zijn weigering nader te omsehrijuen.

$153 \quad 0.36$

De meerderheid van de patienten brengen de arts door hun openheid in het gesprek op een spoor dat niet zuiver medisch is, mar dat nuttig is bij het stellen van een diagnose.

$123-0.51$

Ernstige familiale moeilijkheden die nochtans van rechtswege geen tegemoetkoming voorzien. zouden voor de arts een voldoende reden moeten zijn on aan een "patiënt" een medisch attest ter excuus af te leveren. 
Var. Lading Uitspraak

$124-0.46$ In de medische praxis is het gebruikelijk $z i c h$ tegemoetkomend te tonen ten overstaan van patiënten die slechts bij wijze van vitzondering om een medisch voorschrift verzoeken om niet-medische redenen.

$156-0.38$ De medische uitzendigen van de onderscheiden T.V.-zenders zijn als een noodzakelijke informatie aan het brede publiek aan te moedigen.

$150-0.32$ Wanneer de arts over het warom van de voorgestelde therapie uitleg verstrekt, doet hij dit omdat de patient er recht op heeft.

De uitspraken wijzen er op dat de arts de strikt therapeutische relatie moet weten gaf te houden door aan het gevaarlijk stadium van de "vlucht" in de ziekte het hoofd te bieden.

Het staat aldus de arts vrij een patiënt die een ziekte voorwendt, al dan niet uitleg te geven over zijn weigering een medisch attest af te leveren (lading 0.44). Evenmin is de arts verplicht $z i j n$ weigering nader te omschrijven, wanneer een "patiënt" openlijk bekent dat hij niet ziek is, maar wegens zekere moeilijkheden om een medisch voorschrift verzoekt (lading 0.41 ). Oergelijke houdingen moeten gezien worden in het licht van het geheel van matschappelijke normen langs dewelke de aanpassingsverwachtingen (van de anderen) en het eigen gedragspatroon in de rolvervulling wordt bepald. In de arts-patient relatie verwacht de arts coöperatie, goede wil, begrip voor zijn optreden en verwacht de patient op zijn beurt dat de dokter hem helpt, zij het nu onder vorm van genezing, verlichting of geruststelling.

Een belangrijke inbreng van de arts is echter ook dat hij wellicht de enige persoon is die individuen kan ontslaan van hun normale sociale verplichtingen ("medisch ventiel voor 
matschappelijk falen" zegt VAN DOORN (1956)) en dit op grond van ziekte of onbekwamheid. Wanneer dit zijn opdracht is, dan moet hij dit enkel doen wanneer het nodig is. Dan dient hij de warheid. Hij dient echter de warheid evenzeer, wanneer hij in bovengenoemde situaties weigert een medisch attest af te leveren. Hij moet hmmers op zijn hoede zijn, ten einde te beletten dat in de arts-patient relatie ongewenste morele of wardeoordelen binnendringen, die dysfunctioneel kunnen werken op de zekerheidsuerhoudingen in de medische praxis.

ook ernstige familiale moeilijkheden (lading -0.51) of uitzonderingsgevallen (lading -0.46) horen tot deze stelregel. Immers de arts streeft in zijn optreden naar communicatie en interactie met de patiënt en wanneer deze verwachtingen niet kunnen worden ingelost uit hoofde van een discrepantie met de rolverwachtingen van de patient, kan de medische situatie niet tot stand komen.

De bevolking moet in die $z$ in worden opgevoed. Massamedia kunnen hiertoe een zeer belangrijke bijdrage leveren. Reserves moeten echter worden gesteld. Immers het publiceren in tal van dag-en weekbladen van medische artikels heeft meer kwade dan goede kanten (lading 0.53).

4.5.2. Resultaten van het onderzoek.

Een aantal variabelen, waaronder ook het specialisme, vertonen een significante samenhang met deze rolcomponent.

Wellicht door het grote aanbod van patienten die de arts te veel in functie van hun persoonlijke moeilijkheden opzoeken, zijn de artsen die hun voorkeur op de individuele praxis laten vallen, meer dan zij die de groepspraxis verkiezen, geneigd de formulering van deze component bij te treden, dit als de witdrukking van een afweermechanisme tegen te emotioneel geladen verwachtingen van de patiënt, die zij in de enge "faceto-face" relatie veelvuldig ontmoeten.

Deze afwerende houding vinden we ook duidelijk reer terug bij artsen die in de samenwerking in een medisch team zowel de technische samenwerking als de globale inzet voor het 
welzijn van de patiënt hoog warderen. Wellicht zien zij in dergelijke houding een middel om zekerheid te verwerven in hun optreden of omgekeerd, een middel tot het verwerken van onzekerheden. Zij zien dus die samenwerking positief, d. 1. : op basis van wetenschappelijke kennis de lijdende tegemoet komen. Hun visie over deze component sluit hier direct bij aan. Immers, vreemde wardeoordelen in de medische situatie dulden zij niet, enkel voor reële noden stellen zij met alle begrip hun medische kennis ter beschikking (22).

De tegenhanger van deze vinden we uitdrukkelijk terug bij artsen die enket het welzijn van de patient centraal stellen. Hierbij kan worden overwogen dat deze artsen, meer dan hun andere collega's het risico lopen emotioneel geëngageerd te geraken, daar zij de vakkennis secundair stellen. Het gezagspatroon loopt hierdoor het gevaar niet specifiek geöriênteerd te worden op het domein van ziekte en gezondheid. Vandaar dat ook bij deze artsen er relatief minder personen zijn die zich met de sociaal-opvoedende component, zoals hij hen werd voorgelegd, weten te vereenzelvigen.

Een interessante vaststelling valt ook te vermelden in verband met de ervaring die de artsen met paramedici hebben. zo blijkt duidelijk dat, artsen die verklaren nog niet ervaren te hebben dat, door het optreden van deze hulpkrachten de behandeling van hun patiënten vergemakkelijkt werd, dat zij" "wakzamer" en "strenger" zijn ten aanzien van niet-medische aarbiedingen dan collega's die wel reeds genoemde ervaring opdeden.

Deze vaststelling wordt gesterkt door een twede significante samenhang in dit verband $n l$. dat naarmate de diversiteit van de ervaring met paramedici stijgt, het aantal artsen dat $z i c h$ in de social-opvoedende component terugvinden, daal $t$.

Hieruit mag met een voldoende zekerheidsgraad worden geconcludeerd dat deze artsen de niet strikt-medische gevallen warmee ze geconfronteerd worden, aan paramedici overlaten en zich dan ook minder zelf actief op het sociaal-opvoedend terrein begeven, ipso facto,er zich minder mee weten te identificeren. 
Tenslotte rest de significante relatie met het beoefend specialisme (App.II.25).

Sterk positieve uitlopers treffen we niet aan. De dermato-venerologen en urologen komen hier relatief het meest voor. Is een verklaring moeilijk te formuleren, dan kan geopperd worden dat, gezien zij specialisten zijn waronder significant meer personen voorkomen die een private praxis hebben dan dit het geval is bij de andere specialisten (zijopteren ook duidelijk meer voor de individuele praxis), zij ook meer dan hun collega's de kans lopen, patienten te ontmoeten die voor zogenaamde 'bagatel'-gevallen om een medisch excuus verzoeken.

De situatie van de huisarts ligt anders. Hij, meer dan de andere artsen wordt in zijn dagelijkse praxis geconfronteerd met de risico's, verbonden an te hechte banden met zijn patiênten. In de regel komt hij ten huize, komt hij in contact met het sociaal milieu van de patiënt en krijgt ongevraagd informatie, niet enkel over aangelegenheden die hem nuttig zijn, mar ook over ongevraagde confidenties die de broze grenzen van de medische relatie te buiten gaan. De huisarts blijkt dit meer dan veel van zijn specialistische collega's te ervaren en weet in dergelijke gevallen significant meer dan hen een afstandse houding a an te nemen.

Dat de fysiotherapeuten, reumatologen en radio-radiumtherapeuten, wier disciplines onderling duidelijke aanknopingspunten hebben, hier ook figureren ligt o.i. bij de a ard van het specialisme zelf. Simulatie vanwege de patiënt is uitgesloten: de manifeste ernst van vele gevallen war het in deze specialismen om gaat, belet hen anders te denken. Teveel worden $z i j$ geconfronteerd met aangeboren afwijkingen of zijn $z i j$ specialisten van het "tweede contact" uit hoofde van verwijzingen, warbij de ziekte voór hen reeds werd geselecteerd. 'Excuus'-gevallen komen bovendien uiteraard weinig voor en desgevallęd zijn zijook zo niet bereid van hun 'terzake'-instelling af te wijken. Hun denkpatroon is sterk op reële noden ingesteld. 
Een aanzienlijke a anwezigheid van chirurgen en orthopedisten bij de positieve zelfevaluatie kan worden verklaard uit de hoogst technische aangelegenheid van hun specialisme dat hen wellicht gebiedt zich te distancieren van het emotioneel engagement, wat niet betekent dat hun affectieve neutraliteit absoluut is. Op grond van hun hoge (technische) verantwoordelijkheidszin die zij, zoaks eerder gezien, ten aanzien van de genomen risico's hoog aanschrijuen, groeit wellicht een autoritaire attitude die hen tot radicale beslissingen uitnodigt. In cruciale momenten van de therapeutische relatie dulden zij geen vreemde elementen.

Meer dan andere specialisten zijn zij dan ook wellicht geen fervent voorstander van vulgariserende medische bijdragen van de massamedia die de obsessies van hun tezers en kijkers kunnen verhogen en de medische realiteit vervormen. verder onderzoek zou echter moeten uitwijzen of hun houding $z$ ch in de post-operatieve fase gat wijzigen.

Dat de keel-, neus- en oorspecialisten en oogartsen globaal beschouwd, ook aanzienlijk vertegenwoordigd zijn kan andermal wit de specificiteit van hun specialisme worden verklaard. Door het vigerend systeem van directe bereikbarheid hebben, zoals voldoende gekend, deze specialisten een druk $k l i e ̈ n t e e t$. Uit enige toegevoegde informatie vernemen we echter dat deze specialisten significant minder bekend zijn met het sociaal milieu van hun kliënteel, wat kan wijzen op hun afstandshouding op dit vlak. Hieruit menen we te mogen concluderen dat hun zelfevaluatie als evident kan worden beschouwd.

onder de artsen die zich weinig of niet in de socialopvoedende rolcomponent weten te situeren, figureren verhoudingsgewijze vooral de mondartsen. Dergelijke toegeeflijke houding kan een mogelijke uitleg vinden in de meer labiele verbondenheid in dit specialisme tussen arts en patiênt, wat deze "laconische" uitspraak verklaart. Ook kan de aard van het specialisme,zelf, warin zich slechts weinig patienten met nietmedische redenen aanbieden, een verklaring zijn. 
Dat vervolgens ook de neuro-psychiaters zich zeer duidelijk distanciëren van de sociaal-opvoedende component vergt wel een meer uitvoerige uitleg.

Het arbeidsveld van deze specialisten kan zich op praktisch elk gebied van matschappelijke zorg spreiden. Meer dan om het even welke andere specialist worden zij bezocht door "patiënten" die hun emotionele conflicten niet aankunnen en die een gemakkelijk compromis vinden in de klacht zelf, warmee zij bij inwilliging van de arts, de sociale rol van patiênt toebedeeld krijgen. In dergelijke gevallen war de drie velden van auerido, met name het sociale, het psychische en het somatische veld in voortdurende wisselwerking verkeren en warin elke actie naar alle kanten wordt voorgeleid werkt deze specialist op een witerst moeilijk terrein, dat uiteindelijk dan toch uitdrukkelijk tot zijn competentie behoort waraan hij ook de volte aandacht schenkt en een begrijpende houding aanneemt. Nochtans kan men met deze zeer uitdrukkelijk nagatieve zelfevaluatie het gevoel hebben dat deze specialisten aan het sociaal-opvoedend terrein voorbij gaan. Het resultaat moet echter gezien worden in het licht van dit specialisme. Meer dan andere specialisten is de neuro-psychiater - voor zover zijn activiteiten zich niet op het neurologisch terrein Laten situeren - de arts die gevallen behandelt die, op grond van hun psychische natuur, niet door de huisarts kunnen worden benaderd. Aanvaard moet immers worden dat, de neuro-psychiater toch een bijzondere plaats inneemt in het artsenkorps, daar zijn tussenkomsten weinig of geen technische onderzoeken omvatten, geldt het nu verwijzingsgevallen van internisten, dermato-venerologen of oogartsen, of onderzoek van het eerste contact. Wat er ook van zij, het blijft moeilijk een scheiding te trekken tussen het psychische en sociale veld en dàr juist is de neuro-psychiater zich van bewust. Het is zijn competentie die hem een antwoord moet geven op de vraag : hebben psychische stoornissen secundair sociale stress veroorzaakt of omgekeerd, want wisselwerking is niet uitgesloten. 
Deze complexiteit ligt aan de basis van de negatieve zelfevaluatie, die dan eerder de uitdrukkina is van een twijfel rond het begrippenpar "niet-medische-redenen" in de vraagstelling en van hun competente overtuiging dat, aanbieding van "familiale moeilijkheden" een uiting kunnen zijn van sociale moeheid van de patient, warvoor het steeds de moeite Loont zich een inspanning te getroosten. Die inspanning wordt vooral opgebracht door de neuro-psychiater bij dewelke het in de regel langer durende gesprek valk een verhelderende functie heeft.

Hun zelfevaluatie getuiat dan ook van een bearijpende en zeker niet zo starre houding t.a.v. 'excuus-gevallen'. Wel zal hij desgevallend en zo nodig, dergelijke patiënten op hun matschappelijke verplichtingen wijzen, maar heeft hij dan toch blijk gegeven van begrip voor de aangebrachte moeilijkheden. Herinneren we hier nochtans aan hun evaluatie van het paramedisch equipement war zij ten volle van gebruik maken. We durven hier dan ook opperen dat deze specialisten, in onderhavige gevallen, overtuigd zijn dat die moeilijkheden dan mar best opgelost warden door die paramedici, waar de neuro-psychiater graag naar verwijst.

Weet deze specialist zich aldus op die wijze van een te strakke binding te distanciëren of is dit nu precies een aspect van zijn taak: de mens leren zelf zijn ziekte te hanteren door hem langs 'competente' beroepshulpverleners te letden naar scortgelijke patiëntengroepen waar ze elkaar van nut kunnen zijn?

Treden tenslotte ook de klinische biologen in dezelfde volgorde aan, dan moet hun instelling hier met het nodige voorbehoud worden genomen, daar hun contact met patiënten tot het absolute minimum is herleid en zij zich derhalve op een enge bastis d.w.z. meer als observator en minder als deelnemer hebben geëvalueerd. 
4.6. De psycho-therapeutische/"magische" rolcomponent.

4.6.1. Inleiding.

Een laatste combinatie van uitspraken met betrekking tot de zelfevaluatie van de artsen in hun rolvervulling omvat twalf uitspraken met hoge lading.

Var. Lading Uitsprak

1410.61 om een nauwe samenwerking vanwege de patiënt te bekomen, moet de geneesheer er over waken dat de patiënt de geneesheer idealiseert.

$1420.550 \mathrm{~m}$ een nawe samenwerking vanwege de patiënt te bekomen, moet de geneesheer er over waken dat de patiënt een zekere graad van afhankelijkheid van de geneesheer ontwikkelt.

1590.54 Het intelligentiepeil van de patiënt bepalt grotendeels of de arts tot een gesprek zal overgaan dat niet louter de aandoening van de patient betreft.

$160 \quad 0.47$ In de regel zal de arts eerder een gesprek van niet-medische a ard voeren met patiënten die op een ongeveer gelijk intelligentieniveau staan als hij dan met andere.

148 Wanneer de arts over het warom van de voorgestelde therapie uitleg verstrekt, doet hij dit om de patiënt gerust te stellen.

1460.45 De overtuiging van de arts dat een gegeven geneesmidde! werkelijk effect heeft, bepalt ook in grote mate het wezenlijk effect ervan op het herstel van de patiěnt.

$14 \%$ 0.4 4 De werkzamheid van heel wat geneesmiddelen en behandelingsmethoden wordt eerder bepald door het vertrouwen van de patient in de dokter dan door de objectieve werkzamheid van die middelen zelf. 
Var. Lading Uitspraak

145 0.42 De werkzamheid van heel wat geneesmiddelen en behandelingsmethoden wordt eerder gestimuleerd door het vertrouwen van de patiënt in de arts die ze voorschrijft of toedient, dan door het geloof van de patient in de objectieve werkzaameid van de bewuste geneesmiddelen en behandelingen zelf.

1110.39

Het dragen van de witte doktersjas is ulterst belangrijk voor het wels lagen van de arts in zijn Loopbaan.

$139 \quad 0.38$

Om een nauwe samenwerking vanwege de patiënt te bekomen, moet de arts er over waken dat de patiënt de beslissing van de arts niet betwist.

$140 \quad 0.36$

Om een nauwe samenwerking vanwege de patient te bekomen, moet de arts er over waken dat de patiênt zijn emotionele conflicten bedwingt.

$127 \quad 0.36$

Wanneer een patiënt bewust simuleert ziek te $z i j n$, is het eerder aangewezen de patiënt in te volgen, dan hem er rechtstreeks op te wijzen dat hij niet ziek is.

Hun samenhang duidt er op dat de arts in zijn praxis niet enkel patiênten omwille van hun kwal te behandelen krijgt, maar dat ook als normal te beschouwen, naar dan toch ongewenste neveneffecten uit de weg moeten worden geholpen. Immers over een fysische storing hangt steeds een neurotische sluier van angst of onzekerheid.

Dat de persoonlijkheid van de arts een belangrijke rol kan spelen bij het onderdrukken van dergelijke gevoelens staat vast. Ten allen $t i j d e$ trouwens hebben goede artsen hun zieken steeds bewust of onbewust psychisch beinvloed.

De statements in onderhavige rolcomponent duiden alle op het bestaan van dat psychisch contact dat zowel geconditioneerd wordt door de persoonlijkheid van de arts als door de per- 
soonlijkheidsstructuur van de patjërnt.

zo kan gesteld worden dat het goed is dat de patiënt zijn arts idealiseert (statement met lading 0.61 ) of dat hij een zekete graad van afhankelijkhejd ontwikkelt chading 0.55 ). Duiden deze beide uitspraken nu wel op een overschrijden van de grenzen van het psychisch contact, dan vertolken zij toch de idee van de bindende voorwarde dat, wil de arts zijn patiênt kunnen helpen, hij als eerste opdracht heeft dit contact bij de patiënt in te leiden. Enkel langs deze weg kan de arts-patiënt relatie vitgroeien tot een bijzondere relatie van vertrouwen. M.a.W. de patiënt moet het gevoel worden bijgebracht begrepen te worden. Vanuit psycho-therapeutisch oogpunt betekent dit dat een overdrachtsituatie ontstaat.

Afhankelijk van zowel de persoonlijkheid van de arts als die van de patiënt kunnen hierin belangrijke graduele verschillen bestaan ( $z$ ie ook andere statements : ladingen 0.38 , $0.36,0.36)$.

Ter beoordeling voorgelegd aan zowel huisartsen als aan de onderscheiden specialismen wordt hier witeraard de psycho-therapeutische instelling van de arts in zijn dagelijkse praxis bedoeld. Het is dus een opdracht van elke arts die spanningen, eventueel social geconditioneerde spanningen te verlichten of weg te werken (zie hierover uitvoerig J.A.WEYEL, 1961). Eventueel kan dit door een gesprek, niet het psychiatrisch psycho-therapeutisch gericht gesprek waarvoor enkel psychiaters zijn opgeleid, maar dàt gesprek dat het best kan vergeleken worden met de verhouding tussen de kleine chirurgische ingrepen in de dagelijkse praxis van de huisarts en de 'grote chirurgie' van de heelkundige.

Speelt de persoonlijkheid van de arts, zo kan mede in verband met de persoonlijkheid van de patient, zijn ontwikkelingsniveau of zijn intelligentia gesteld worden dat het intelligentiepeil van de patient grotendeels bepalt of de arts tot een gesprek zal overgaan dat niet louter de aandoening van de patient betreft (lading 0.54 ) of dat de arts in de regel eerder een gesprek van niet-medische aard zal voeren met patienten 
die op een ongeveer getijk intelligentieniveau staan als hij dan met andere (Lading 0.47 ). Studies hieromtrent in de U.S.A. duiden er inderdaad op dat patiënten die het dichtst de status van de behandelende arts benaderen, de beste behandeling krijgen en de meeste sympathie genieten. Dergelijke instelling van de arts valt te betreuren daar zij de vertrouwelijke omgang in de weg staat.

Deze bijzondere verhouding is een onmiskenbaar noodzakelijk moment. Immers, wanneer een zieke op grond van een bepald onbehagen meent de dokter te moeten opzoeken, betreedt hij de dokterspraktijk met een zekere afwachtende houding, hij verwacht contact. Dit contact is, zoals we hoger reeds zegden niet enkelvoudig, dus niet direct op het geneesmiddel of een gebruikelijke behandelingsmethode gericht. Immers elke arts kent voldoende momenten in zijn praxis, waabij hij psycho-therapeutisch moet optreden en weet ook dat het beste geneesmiddel zijn werking kan verliezen, wanneer de patient het vertrouwen in de arts verliest en meteen het vertrouwen in het voorgeschreven geneesmiddel (drie statements met ladingen : 0.45 , $0.44,0.42)$.

Geestelijke beinvloeding op vele ziekten heeft steeds bestaan. Van de magische geneeskunde is bekend dat de ziekte een "bezeten zijn van geesten" was, dat medicijnman en tovenaar de macht hadden die geesten te verdrijuen. Heden ten dage worden Lourdes en scherpenheuvel nog druk bezocht... "Uw Geloof heeft U geholpen"... War echter in de moderne geneeskunde geloof en suggestile alleen werkzaam zijn, valt moeilijk te zeggen. Veel hooggeprezen geneesmiddelen in de moderne geneeskunde kennen een lang succes dat niet noodzakelijk uit natuurwetenschappelijk causaal oogpunt te verklaren is, maar uit de moderne vorm van toverij, propaganda, massasuggestie, de suggestieve persoonlijkheid van de arts en de in twijfel verkerende patient die in suggestie vervalt en waraan de arts ook wel eens 'bezwijkt'. In elk geval is het een feit dat het geneesmiddel 'dokter' vak onder de vorm van geruststelling (lading 0.45) wordt toegediend. "In de geneeskunde en in de arts heeft de patient steeds 
een 'magisch' element onderkend, gezocht, ja zelfs verlangd, daar in de diepste grond 'bijgelovige' aspiraties het vertrouwen in de eigen genezing vaak zeer sterk stimuleren" (JANSSENS, . $1964)$.

In de wetenschappelijke, westerse geneeskunde verdringt echter de techniciteit te radicaal de rol van dit 'magisch" element in de arts-patiënt relatie. Naar zijn precieze watrde gemeten en aangewend d.w.z. als geesteswetenschappelijk causaal, verantwoord hulpmiddel kan dit irrationeel element in de praxis nochtans vaak een gunstig effect sorteren. Het dragen van de doktersjas (lading 0.39) mag dan niet zomar als een gewoonte worden gezien, maar als een accentuering van de medische situatie.

De hierboven omschreven rolcomponent stat met een paar achtergrondgegevens in significante relatie. We bespreken ze hierna. Naast deze gaat onze aandacht evenwel ook naar de confrontatie met het beoefend specialisme waar geen global significante relatie werd vastgesteld, mar war bepalde deelresultaten (fracties van specialismen) ons toch litnodigen er even te blijven bijstilstaan.

4.6.2. Resultaten van het onderzoek.

Bij voorgaande samenhang lijkt het ons nuttig bij herhaling vooraf te beklemtonen dat de basis van een optimale artspatient relatie gelegd wordt door het tot stand komen van een overdrachtsituatie m.a.w. een situatie van vertrouwen. Die verirouwenssituatie mag niet worden gekenmerkt door een wederzijdse emotionele instelling in het lichamelijk en geestelijk ziekteverschijnsel. Persoontijke betrokkenheid van bejde partijen moet worden gew eerd, omdat een bindend relatiepatroon niet alleen kwetsbaar is maar. wat bezwarender is, het staat het psycho-therapeutisch optreden van de arts in de weg. De overdracht bestabt dus wit een zeer intiem psychisch contact dat gaaf moet blijuen en warvan de grens varieert naargelang de persoonlijkheid van de betrokken partijen. 
We gaan nu eerst na welke variabelen de zelfevaluatie van de artsen in deze rolcomponent differentiërend dicteren. Een confrontatie met de leeftijd van de respondenten toont zeer duidelijk aan dat de twee categorieën van jongste artsen (jonger dan 50 jaar) het meest $k r i t i s c h$ staan tegenover de hen voorgelegde statements. Idealiseren van de arts aanvarden zij niet of althans heel wat minder dan hun oudere collegats.

Aanvaarden we echter dat een zieke zich gemakkelijker zal toevertrouwen an een oudere geneesheer en ook dat deze op psycho-therapeutisch vlak meer ervaren is, dan toch menen we dat hij op grond van een overgedoseerde emotionaliteit, zij deze nu al dan niet in een integrale visie op de ziektebenadering ingebouwd, hij meer dan de jongere artsen de kans loopt in een te bindend relatiepatroon met zijn patienten verzeild te geraken; grotere ervaring leidt immers niet noodzakelijk tot een meer positieve kijk op de dingen. Deze uitspraak kunnen we op giond van een aanvullende vraagstelling ondersteunen met de vaststelling dat ongeveer tweederden van de respondenten verklaren dat het a antal patiënten die men bedient, niet meespeelt in het tot stand komen van een harmonieuze arts-patient relatie. verder stellen we vast dat voorstanders van groepspraxis zich meer distanciëren van een te sterke binding dan hun collega's die een individuele praxis verkiezen. Zij voeren trouwens aan. zoals we vroeger zagen, dat groepspraxis meer positieve elementen dient zoals : kwaliteitszorg, verrijken van kennis, betere planning, meer afficiënte praxis, enz... daar war de voorstanders van de individuele praxis duidelijk de nadruk leggen op gevoelselementen zoals: sterke persoonlijke binding, vrijheid, toewijding, enz... waarbij andermal het risico vergroot dat, de in de therapeutische relatie toela athare grenzen van het pychisch contact worden overschreden, wardoor de patiënt dus de kans wordt geboden de arts teveel als persoon te benaderen.

Andere duidelijke significante relaties treden niet op, ook niet naar specialisme (App.II.26). 
Nochtans bieden zich, ondanks het ontbreken van een totale significantie naar specialisme, enkele fracties van spechalisten an dife een bijzondere andacht verdienen.

zo noteren we bij de neuro-psychiaters relatief het meest personen die zich ultdrukkelijk kanten tegen een te sterke binding met de patiënten. Dit lijkt ons een logisch resultaat daar deze specialist, gezien zijn uitzanderingspositie in de specialictenwereld - voor de zieke hoort de arts immers op zichtbare of op direct tastbare wijze tussen te komen en dit doet de psychiater niet - de arts is die verondersteld mag worden en of andere vorm vanpsychotherapeutische behandelingsmethodes ander de knie te hebben.

Zoals in de inleiding van dit hoofdstuk reeds vermeld, kunnen ook een blind geloof en ook een vertrouwen in het medisch optreden, mar ook de dokterskledij als irrationele elementen een gunstig effect sorteren. Deze zienswijze wordt dus door die $1 / 3$ van de psychiaters van de hand gewezen. Hier mogen dan ook de minder streng negatieve ingestelde psychiaters worden bijgerekend en dan zijn er meer dan de helft van deze specialisten die geen duidelijke therapeutische functie toemeten aan blind geloof of witte jas. De rest doet het wel, dit is ook belangrijk.

Recente polemieken over gezondheidszorg en gezondheidsbeleid nodigen ons in dit verband wit tot enkele verdere overwegingen. ook kunnen enkele losse gegevens, zowel uit voorliggend onderzoek als wit eigen onderzoek bij 823 potentiele patiênten, in deze context van enig nut zijn.

Dat veel artsen psycho-somatische aandoeningen en er aan gekoppeld de interpretaties het liefst uit de weg gaan (tweederden van de respondenten verklaren dit) en emotionele gevallen ook geer warm hart toedragen (bijna tweederden), kan er op duiden dat zij ofwel de wetenschappelijkheid van de intappretaties ervan in twijfel trekken, ofwel dat ze zich incompetent weten. 
Zonder specifiek onderzoek terzake is het witeraard niet mogelijk met zekerheid te weten of deze vaststellingen het resultaat zijn van een te orthodoxe opleiding die onze artsen genieten, ofwel verklaard moeten worden wit de niet of althans niet tenvolle geslaagde aanpassing in hun rolpatroon. En was het slechts dit. Heel wat artsen staan bovendien nog altijd zeer argwanend tegen psychiatrische inmenging en dit is te begrijpen. De psychiatrie heeft zich immers vooral op het terrein van de geesteszieken ontplooid en niet zozeer op het psycho-somatische vlak, war toch heel wat artsen (steeds veelvuldiger) mee te doen krijgen, mar er zich, zoals gezegd, wellicht niet competent in voelen.

Het zal er bij deze artsen dan ook moejlijk ingaan, dat ze in psychiatrische methoden 'evenveel" vertrouwen moeten hebben als in de valk weliswar nodige ingrepen van een chirurg of in het toedienen van een geneesmiddel.

Deze beschouwingen, dachten we, zijn hier in het licht van enige a anuullende informatie die we verzamelden, nuttig aan te voeren. Zo kan best het wantrouwen ten aanzien van de psychiatrie blijken, enerzijds wit de geringe belangstelling "tout court" vanwege de artsen voor dit specialisme (amper $9 \%$ van de respondenten verklaren dit expliciet), anderzijds wit het samenwerkingspatroon tussen psychiaters en andere artsen. Zo stellen we vast dat de psychiaters slechts zelden om advies of informatie worden verzocht, zij slechts bij uitzondering op consult worden uitgenodigd en zij enkel door een drietal andere specialismen verwijzingsgevalten krijgen (23).

bit betekent niet dat de meerderheid van de artsen de psychiatrische inbreng in tal van fysische stoornissen verwerpen, mar dat hun belangstelling niet verder gat dan díe inbreng te erkennen. Dit erkennen beperkt zich dan ook vaak tot het louter voorschrijuen van een kalmeer- of een slapomiddet.

Aan het werkingseffect van placebo's dat buiten het bereik van de natuurwetenschappelijke geneeskunde is gelegen mag hierbij niet worden voorbijgegaan. Placebowerking is een feit. 
De over rompelende en steeds groeiende markt der farmaceutische middelen zijn er het bewijs van. "Een nieuw, duur en 'uit-Amerika-komend" produkt moet bijzonder goed zijn".

voor veel van die produkten geldt goeddeels een soort dogmatische instelling t.a.v. de mogelijkheid van een uitwerking. Dit hangt dus af van de patiënt, van zijn innerlijke overtuiging dat een geneesmiddel zal helpen of... zal schaden.

Dit placebo-effect treedt evenwel niet autonoom op. Het geneesmiddel 'arts' zorgt hiervoor door het terrein voor te bereiden, te effenen. De overtuiging van de arts in de juistheid van zijn handelen wordt immers vaak op de patiént overgedragen. Deze overdracht berust echter niet op zijn natuurwetenschappelijke scholing, maar op wat uitgaat van zijn persoonlijkheid. In het complex stel van factoren die de persoonlijkheid van de arts kunnen bepalen, figureert het rolpatroon dat hem als arts werd toebedeeld.

Elk individu percipieert dit rolpatroon echter op verschillende wijze, dit bleek voldoende duidelijk uit het onderzoek. Maar éen feit staat vast : het geneesmiddel 'arts' is werkzaam. Pijnloze bevalling, autogene training (waar de relaxmethode slechts een voorwendsel is tot contact), yoga en hypnose,zijn voorbeelden van. Geloof en volledige onderwerping zijn er de voorwarden toe.

Het zou dan ook irreéel zijn a an deze menselijke verbondenheden te verzaken. "Magische' verbondenheden kunnen we ze bezwarlijk noemen, maar bij heel wat zieken in reële en vermeende nood, zo menen we, is "magisch" denken reëel. Derhalve zijn de artsen geroepen dit als werkelijkheid te aanvaarden. Doen zij het niet, dan openen zij meteen nog wijder de deuren voor kwakzalvers en genezers die total buiten het perspectief van de orthodoxe natuurwetenschappelijke geneeskunde opereren (CASSEE, E.Th., 1973). Heel wat patiënten weten wel dat deze genezers geen geneeskunde kennen, maar weten wél dat er dergelijke mensen bestaan die kunnen genezen en dat is kapi-
taal. 
In hoeverre onze artsen en vooral de neuro-psychiaters in hun praxis enerzijds de geesteswetenschappelijke benadering centraal stellen, of ze aan empirisch wetenschappelijke studie onderwerpen of... religie laten meespelen, hebben we niet achterhald.

We stellen enkel vast dat, ondanks het ontbreken van een totale significante relatie naar specialisme, vooral de gynaecologen met hun aanzienlijke vertegenwoordiging, onderhavig geformuleerde rolcomponent bijtreden en aldus ook het geneesmiddel 'arts' duidelijk onderschrijven. De cardiologen en longartsen scheiden zich ook nog duidelijk af. Spelen zij in de wije van a anbreng van de diagnose het best in op de noden van de in deze context voldoende gekende angstgevoelens van de patiěnten? Zie trouwers ook hun top-positie in hun zelfwaardering van de informatieve rolcomponent. Gezien de niet significante relatie onthouden we ons bij deze component van ruimere interpretatie.

We menen hier dan ook te mogen concluderen dat er zich wit hoofde van een paar duidelijke uitspraken ten gunste van de persoon van de arts, een nieuwe wetenschappelijke stroming afzet tegen de opdringerige markt van de geneesmiddelenindustrie.

Beantwoorden aan het natuurlijk streven van de mens om in de persoon van do arts genezing, verlichting of steun te vinden is halbaar hangs een ontsluiting van de strenge orthodoxie van onze gezohdheldszorg. Aan alternatieve geesteswetenschappelijke ontwikkelingen, die ankeunen bij de harmoniserende functie van een kleine fractie van onze hedendaagse psychiaters, mot een kans worden gegeven. We bedoelen dat bij de studie van de orthodoxe geneeskunde met de realiteit van vaak bijzonder goede resultaten van onorthodoxe bewandelde wegen moet rekening gehouden worden.

In therapeutisch opzicht is het echter geboden de volle a andacht te blijuen richten op de natuurwetenschappelijke ontwikkelinger in de geneeskunde. 
4.7. Samenvatting.

De behandelde componenten, in essentie aspecten van de rolverwachtingen van de arts, hebben we gezien als een geheel van verantwoordelijkheden die de arts verondersteld wordt te nemen, wil hij beantwoorden a an de in de matschappij vigerende normen. Door zijn antwoord heeft de respondent zich in deze rolcomponenten geëvalueerd.

De eigenwardering in de social-integratieve rolcomponent, waruit blijkt in welke mate de arts de wederzijdse erkenning van rollen in de arts-patient relatie evalueert, zich inleeft of inwerkt in de omgevende milieufactoren en begrip aan de dag legt voor diepmenselijke problemen, heeft significante verschillen aangetoond met de leeftijd van de arts, met zijn evaluatie van de genoten academische opleiding en met zijn wardering voor medisch teamwerk. Was er geen significante relatie met het beofend specialisme, dan blijken de neuropsychiaters zich toch beter dan de andere artsen in de component te identificeren.

De eigenwardering in de informatieve rolcomponent verschilt wel naargelang het beoefend specialisme. Vooral de cardiologen, longartsen, mondartsen en klinische biologen treden hier naar voor, de huisartsen heel wat minder. ook de neuropsychiaters verschijnen slechts zwak.

De eigenwardering op het sociaal-opvoedend vlak verschilt duidelijk naargelang de arts een private of een ziekenhutspraxis beoefent. Verder is het tekenend dat vooral chirurgen, orthopedisten, keel-, neus- en oorspecialisten, oogartsen, fysiotherapeuten, reumatologen en radio-radiumtherapeuten, alle vreemde elementen uit de therapeutische relatie weren, die de zekerheidsverhoudingen in het gedrang zouden kunnen brengen, maar hun denkpatroon op randmedisch gebied is niet afgerond. Wellicht dicteert de drukke praxis van de huisartsen hen, zich duideljjker af te tekenen op dit vlak. De neuro-psychjaters, eveneens zwak aanwezig, oriënteren zich terzake meer naar het randmedisch hulpequipement. 
De eigenwardering in de psycho-therapeutische/'magische" rolcomponent werd voldoende omschreven om te wijzen op het uiterst complex en moejlijk karakter van dit facet van de medische praxis, war verder onderzoek geboden is (24).

Uit hoofde van de ingewikkelde processen die een patiënt naar de psychiater kan voeren, maar ook uit hoofde van zijn individueel geconditioneerde behandelingsmethoden, zo dachten we, mogen de vele onzekerheden en gerechtvaardigde twijfels echter niet het voorwerp zijn van een 'teugel-loze' delegatie van bevoegdheden aan paramedische tussenschakels, waarop deze specialist vaak beroep doet. Hiermee bedoelen. we dat, vooral in deze discipline, streng moet worden gewakt over de wijze warop die bevoegdheden worden toevertrouwd aan beroepshulpverleners, wier vorming te eng op de praktijk is afgestemd. Het risico dat genoemde onzekerheden kunnen escaladeren naar te zelfzekere routinematige handelingen van niet-geneeskundigen, lijkt ons hierbij immers niet uitgesloten.

In vraag kan dus gesteld warden of dit soms niet het terrein is war de zelfevaluatie van de neuro-psychiaters nog niet een reflectie kàn zijn van de verwachtingen van de patiënt en conflictsituaties derhalve ook niet uitgesloten zijn. "Ze zijn moedeloos want ze beseffen dat ze nog heel weinig weten. In tegenstelling tot de (andere) geneesheren voelen ze zich nog in de middeleeuwen" zegt Milos fORMAN naar a anleiding van zijn film "One Flew over the Cuckoo's Nest".

Zo extreem als de neuro-psychiater naar voren treedt, zo extreem klinkt misschien ook deze uitspraak. Immers, zo zegden we reeds, niet enkel de patient moet als een gehele persoon worden gezien, maar ook de arts en zo geldt dan ook voor de neuro-psychiater dat :

"Parfois la magie réussit. C'est que certains individus possèdent. vraiment une force de suggestion considérable qui n'est pas, d'ailleurs, nécessairement métapsychique, et que la suggestibiljté des gens, comme leur simplesse est sans limites" (HAESAERT, J., s.d.). 
HOOFDSTUK $V$.

SYNTHESE.

INLEIDING.

De onderzoekgegevens werden totnogtoe in een antal statistisch significante relaties vastgelegd.

Desondanks kan elk resultaat dat uit de onontbeerlijk kwantitatjeve analyse wordt verkregen toch nog worden gezien als een uit zijn ruimer verband losgerukt facet.

De wit dergelijk differentieel onderzoek simultaan optredende gelijkenissen en ongelijkenissen kunnen immers niet op elk moment worden onderzocht. Het lijkt ons dan ook wenselijk tot verdere profilering over te gaan van de informatie ons door de opiniërende artsen gegeven.

Dit komt neer op het verstrekken van een meer compacte weergave van de resultaten, door ze aan een of andere geavanceerde berekeningstechniek te onderwerpen (25). De onderzoekingsresultaten lenen zich in dit opzicht tot een dubbele benadering. Enerzijds komt het ons nuttig voor attitudes en evaluaties elk afzonderlijk te onderzoeken nar hun graad van afhankelijkheid van een aantal achtergrondvariabelen tesamen.

Anderzijds is het evenwel wenselijk, ten behoeve van een grotere bevattelijkheid van het geheel, na te gaan of die attitudes en evaluaties op grond van hun gelijkenissen of ongelijkenissen te groeperen zijn in dimensies en ze verder om de beurt te onderzoeken nar hun afhankelijkheid van genoemde achtergrondinformatie. 
5.1. INVLOED VAN ACHTERrRONDVARIABELEN OP OPINIES, ATTITUDES EN EVALUATIES.

5.1.1. Algemeen.

Een aantal achtergrondvariabelen staan in significante relatie tot opinies, attitudes en evaluaties vande artsen. Dit blijkt reeds uit voorgaande hoofdstukken.

Bij onderhavige analyse moet verzaakt worden aan het sociaal milieu van de praktijkvoering daar deze item slechts bij uitzondering een significante relatie vertoont.

om nu de invloed, niet van slechts éen, maar van de onderscheiden achtergrondgegevens tesamen, op de afzonderlijk gehouden attitudes en evaluaties na te gaan, wordt beroed gedaan op stapsgewijze meervoudige regressieanalyse als multivariate techniek. Deze laat ons de variantie zien die in één afhankelijke variabele stapsgewijze door meerdere onathankelijke variabeLen wordt verklaard.

Bij deze analyse weerhouden we voor interpretatie enkel die attitudes en evaluaties, die voor méer dān $3 \%$ a an de werking van de beschouwde onathankelijke variabelen onderhevig zijn.

Uit de analyse (App.V.1) blijkt dat acht afhankelijke variabelen aan deze eis voldoen.

Ter samenvatting van de resultaten volgende tabel: 
Tabel 8. Orde van belangrijkheid warin vijf achtergrondvariabelen de acht weerhouden attitudes en evaluaties verklaren.

\begin{tabular}{|c|c|c|c|c|c|}
\hline \multirow[b]{2}{*}{$\begin{array}{l}\text { Te verklaren } \\
\text { veranderlijke }\end{array}$} & \multicolumn{5}{|c|}{$\begin{array}{l}\text { orde van belangrijkheid der } \\
\text { achtergrondvariabelen }\end{array}$} \\
\hline & 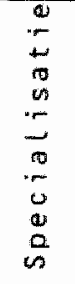 & 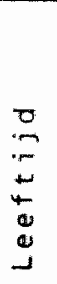 & 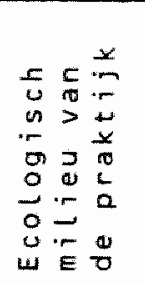 & $\begin{array}{l}E \\
2 \\
0 \\
> \\
0 \\
0 \\
x \\
0 \\
0 \\
0\end{array}$ & $\begin{array}{l}1 \\
0 \\
4 \\
0 \\
0 \\
0 \\
0 \\
0 \\
0 \\
0 \\
0 \\
0 \\
0 \\
0 \\
0 \\
0\end{array}$ \\
\hline $\begin{array}{l}\text { - Oordelen dat veel/weinig } \\
\text { randmedische gegevens als } \\
\text { routineinformatie moet } \\
\text { worden ingewonnen }\end{array}$ & 1 & 3 & 2 & 4 & - \\
\hline $\begin{array}{l}\text { - Drukken hun voorkeur uit } \\
\text { voor individuele of } \\
\text { groepspraxis }\end{array}$ & 2 & 3 & 5 & 1 & 4 \\
\hline $\begin{array}{l}\text { - ondanks toenemend aantal } \\
\text { specialisten blijft de } \\
\text { verantwoordelijkheid van } \\
\text { de huisarts over een lan- } \\
\text { gere termijn (niet) be- } \\
\text { staan }\end{array}$ & 1 & 2 & - & - & - \\
\hline $\begin{array}{r}\text { - De belangrijkste taak van } \\
\text { de arts is helpen/genezen }\end{array}$ & $?$ & 1 & - & - & 3 \\
\hline $\begin{array}{l}\text { - Identificeren zich zeer } \\
\text { duidelijk/slechts zwak in } \\
\text { de informatieve rolcompo- } \\
\text { nent }\end{array}$ & 1 & 2 & 4 & 3 & - \\
\hline $\begin{array}{l}\text { - Oordelen dat hun academische } \\
\text { opleting zeer adequat } / \text { niet } \\
\text { zeer adequal is geweest }\end{array}$ & $?$ & $\uparrow$ & 4 & - & 3 \\
\hline $\begin{array}{l}\text {-Verklaren. in hun praxis } \\
\text { reeds/geen gunstige erva- } \\
\text { ring gehad te hebben met } \\
\text { het optreden van paramedi- } \\
\text { sche hulpkrachten }\end{array}$ & 1 & - & - & 3 & 2 \\
\hline $\begin{array}{l}\text { - zijn van oordeel dat in de } \\
\text { opleiding het accent op de } \\
\text { algemeen medische vorming/ } \\
\text { specialisatie moet worden } \\
\text { gelegd en dat in de praxis } \\
\text { de psycho-sociale context } \\
\text { (niet) moet worden betrokken }\end{array}$ & 1 & 2 & - & 4 & 3 \\
\hline
\end{tabular}


Voor de meerderheid van de we rhouden afhankelijke variabelen is het specialisme dat de arts beoefent, de meest verklarende variabele. Het is opvallend dat het vooral at itudes en evaluaties betreft warin het randmedisch aspect van de praxis wordt belicht.

Het beoefende specialisme is echter ook nog van enige betekenis bij de evaluatie van de genoten academische opleiding, de voorkeur voor de ene of andere praxisvorm en bij het aanduiden van het kernpunt van het medisch optreden, met name het curatief element. In dit latste geval is evenwel de leeftijd de belangrijkste determinant. Deze factor speelt trouwens ook sterker dan het specialisme bij de beoordeling van de genoten academische opleiding, gezien de resultaten in hoofdstuk 2.1 .1 .

Een verwacht resultat is ook dat de voorkeur voor de individuele praxis of voor de groepspraxis het sterkst atharkelijk is van het fejt of de betrokken arts al dan niet de private praxis beoefent.

De invloed tenslotte van het ecologisch milieu en van de beroepserfelijkheid is nauwelijks merkbaar.

Uit wat voorafgat kan dan ook worden geconcludeerd dat beoefend specialisme en leeftijd van de arts de meest uitgesproken verklarende variabelen zijn en we ze derhalve weerhouden voor de verdere analyse.

Zoals in de Inleiding vermeld, beschouwen we in hoofdstuk 5.1 .2 een aantal afzonderlijke attitudes en evaluaties war de invtoed var beide variabelen t.a. v. het gehel van de onderzochte populatie als een onweerlegbare relatie geldt. De eis, aan het onderzoekingsmateriaal gesteld kan dus streng genoemd worden. Immers, behoudens de in tabel 8 betrokken variabelen, zijn er ook andere war leeftijden specialisme determinerend zijn, mar war het significante verschil zich "slechts" manifesteert wanneer bepalde specialismen of fracties daarbinnen (leeftijdscategorieën) van de rest worden afgezonderd. 
Gezien evenwel alle voornoemde deelfacetten in de loop van deze studie reeds ruimschoots de aandacht kregen, wordt hierna enkel stilgestaan bij de meest opvallende relaties.

Daar het medisch verkeer het resultat is van ingewikkelde groeiprocessen, war opinies, attitudes en evaluaties interdependent zijn en niet rechtstreeks warneembaar, wordt in het Hoofdstuk 5.2. gepoogd dimensies in dit verkeer te ontdekken en deze in functie van het beoefend specialisme en het leeftijdsverschil te verklaren.

De ruwe scores van zowel de gegevens in het eerste als van die in het tweede Hoofdstuk worden omgezet in standaardscores ten einde meer inzicht te verkrijgen in de resultaten en om ze onderling beter te kunnen vergelijken. Een standaardscore duidt immers rechtstreeks de afstand aan warmee de ruwe score afwijkt van het gemiddelde, berekend in functie van de standaardafwijking. Dergelijke transformatie van de ruwe scores toont aldus aan of de scores boven (tteken) of onder (-teken) het gemiddelde van de spreiding liggen.

De standaardscores in het eerste deel worden berekend volgens de formule:

$$
Y_{i}=\frac{\bar{x}-m_{i}}{\sigma}
$$

warin $\bar{x}=$ gemiddelde en $m_{j}=$ de ruwe score van waarneming $i$. 
5.1.2. Specialisme en leeftijd als verklarende factoren voor een a antal afzonderlijke attitudes en evaluaties.

1. Het routinematig betrekken van veel/weinig randmedische informatie in de praxis.

Het leeftijdsverschil binnen het specialisme speelt amper een rol (App.V.1). Derhalve verstrekt de tabel (App.V.2.1) enkel de scores en hun rangorde per specialisme.

Bij het overzien van de scores valt het onmiddellijk op dat de neuropsychiaters en de kinderartsen het betrekken van randmedische informatie niet beperken tot enkele gegevens. Integendeel, zij oordelen dat heel wat informatie interessant genoeg is om ze routinematig in de praxis te betrekken. Verder kan worden vastgesteld dat de klinische biologen, de huisartsen, de internisten en gastro-enterologen ook nog boven het gemiddelde scoren en zij derhalve het belang inzien randmedische informatie op ruime schaal als routine-materiaal te verzamelen.

onder de overige specialisten die alle beneden het gemiddelde scoren, vinden we vooral technisch gerichte disciplines terug, warvan de keel-, neus- en oorspecialisten en oogartsen de laagte rang bekleden met een score die zich duidelijk distancieert van de rest.

2. Voorkeur voor de individuele of voor de groepspraxis.

Uit het desbetreffende hoofdstuk (2.2.4) weten we reeds dat de leeftijd en het beoefend specialisme en vooral het onder scheid tussen huisarts en specialist de voorkeurshouding van de arts bepalen.

Uit voorliggende benadering blijkt echter dat aan de invloed van voornoemde factoren slechts een relatief belang mag worden gehecht. Het leeftijdsverschil speelt slechts een zwakke rol, het onderscheid naar specialisme is ook slechts van secundair belang. Wel wordt de voorkeur voor één van beide praxisvormen het sterkst verklaard door het feit of de betrokken arts effectief de private praxis beoefent of niet, waruit bij herhaling kan worden benadrukt dat de voorkeurshouding van de artsen voor 
één van beide praxisvormen op een concardantie duidt tussen realiteit en ideologie.

3. Ondanks het toenemend aantal specialisten, blijft de verantwoordelijkheid van de huisarts over een langere termijn bestaan.

Zowel het beoffend specialisme als de leeftijd van de arts bepalen zjjn houding ten aanzien van deze uitspraak (App. V.2.2.).

Aan de hoge score van de jongere mondartsen moet worden voorbijgegaan daar $z i j$ numeriek te $z$ wak vertegenwoordigd zijn.

Het is opvallend dat bij de hogere scores duidelijk meer jongere artsen voorkomen dan oudere en wat meer is, dat het om technici gaat (röntgenspecialisten, keel-, neus- en oorspecialisten en oogartsen) die de continuiteit van de zorgals onlosmakelijk van de huisartsenpraxis stellen. Dit geldt ook voor de jongere huisartsen zelf (de ouderen scoren duidelijk lager) en de oudere anesthesisten.

Dit leeftijdsverschil gat niet op voor de neuropsychiaters en de klinische biologen. De instelling van de neuropsychiaters doet niet onverwacht aan, trouwens voorheen reeds wist deze specialist zich in heel wat opzichten van de orgaanspecialisten te onderscheiden. De noodzaak tot continuiteit, tot "duur'zamheid kan hij vanuit zijn specialisme best warderen.

Een verklaring voor de positie van de klinische biologen werd in hoofdstuk 3.4. reeds in functie van hun isolement geschetst.

opvallend lager in de rangorde staan, benevens de oudere huisartsen, cardiologen, longartsen en rötgenspecialisten, een antal jongere specialisten.

Dat oudere huisartsen eerder afzijdig staan van een langer durende verantwoordelijkheid, kan voortspruiten wit een gevoel van onmacht het hoofd te bieden a de snelle tred van de specialisatie. 'specialisatie hoort bij specialisten' oordelen zij wellicht en doen dan ook liefst de handen af van dergelijke gevalten. Hierbij kan men zich afvragen of hij, als sleutelfiguur 
in de arts-patiënt relatie dan niet voorbijgat aan het principe van continuiteit van de medische zorg door, nà verwijzing, het contact met zijn patient te verliezen of het niet terug op te eisen.

Het verschil tussen oudere en jongere artsen van de overige disciplines is niet zo scherp. Wel valt het op dat de middenrangen vooral bezet worden door jongere artsen en dat lagere posities vooral door ouderen worden bekleed; maar toch mag niet worden voorbijgegaan aan de vaststelling dat, nast uitgesproken technici, ook oudere kinderartsen en gynaecologen figureren met lagere scores. Daar ook de jongere generatie van deze laatstgenoemden lager scoren, kan ter verklaring best vastgehouden worden aan de reeds eerder aangevoerde overweging omtrent de bijzonderheid van de categorieën van de patiënten in deze disciplines. Deze specialisten situeren blijkbaar de continuiteit van de zorg in hun eigen discipline.

Voor de resterende laag scorende specialismen gat het in de meeste gevallen om disciplines die zich in het specialisatieproces reeds vroeg hebben afgescheiden en vooral wat de ouderen betreft, zijn deze wellicht sterker dan de jongeren vervreemd geraakt van de warde die aan de continue betrakkenheid in de huisartsenpraxis moet worden gehecht.

4. Helpen/genezen is de belangrijkste opdracht van de arts.

ook hier hangt de instelling van de arts zowel van beoefend specialisme a!s van zijn leeftijd af (App.V.2.3.).

Het is merkwardig dat de jongere kinderartsen, huisartsen, neuropsychiaters, internisten en gastro-enterologen het helpen van de patiênt primair stellen, daar waar hun oudere collega's duidelijk het genezen van de patient het belangrijkst vinden. De jongere generatie van deze alle opvallend contextbehoevende disciplines tekent zich aldus duidelijk af.

ook de oudere klinische biologen oordelen dat helpen in de eerste plaats komt. De gynaecologen zijn de enjge specialisten die in hun geheel het helpen centraal stellen, al zij het met een 
niet te hoge score.

Voor alle dermato-venerologen en urologen en ook voor de oudere chirurgen, orthopedisten, fysiotherapeuten, radio-radiumtherapeuten, reumatologen en huisartsen staat genezen van de patie̊nt als primaire opdracht.

5. Identificeren zich zeer duidelijk/slechts $z$ wak in de informatieve rolcomponent.

Uit het desbetreffende hoofdstuk zal men zich herinneren dat cardiologen, longartsen, klinische biologen en gynaecologen zich het best in deze rolcomponent weten te identificeren. Bij deze benadering vinden we ze uiteraard terug, maar tach speelt het leeftijdsverschil enigszins een rol (App.V.2.4.). Tekent zich dit verschil evenwel niet zo scherpaf, dan stelt het zich wel heel wat duidelijker bij de neuropsychiaters en de kinderartsen. De oudere generatie van beide disciplines weet zich in het verstrekken van informatie aan de patient meer expliciet terug te vinden dan de jongeren onder hen.

we beperken ons tot deze hoofdtrekken.

6. Verklaren dat de academische opleiding die zij genoten, adequat/niet adequat is geweest.

Andermal wordt deze evaluatie zowel door het beoefend specialisme als door de leeftijd van de arts geconditioneerd.

vooral de jongere generatie van de artsen uit scherpe krtikek op de genoten basisopleiding (App.V.2.5.). Dit lazen we reeds in het betreffende hoofdstuk. Meer bijzonder evenwel is, dat dit leeftijdsverschil bij bepalde specialismen mér speelt dan bij andere. Zo bijvoorbeeld staan jongere klinische biologen, kinderartsen, neuropsychiaters, internisten en gastro-enterologen, keel-, neus- en oorspecialisten en oogartsen en gynaecologen heel wat kritischer dan hun oudere collega's. Dit geldt ook wel voor de andere specialisten, mar niet in zo sterke mate.

renslotte kan het enigszins onverwacht aandoen vast te stellen dat dit verschil zich het minst bij de huisartsen aftekent, maar zo onverwacht is dit wel niet wanneer we de door hen geformuleerde kritiek naar zijn inhoud gaan analyseren. 
Reeds vroeg klaagt deze arts het tekort a an allerlei menselijke contacten in zijn opleiding aan en dit geldt des te meer voor zijn jongere collegaks.

7. Verklaren gunstige ervaring/geen dergelijke ervaring te hebben met het optreden van hulpkrachten in eigen praxis.

Zien we bij een par specialismen wel enig verschil in de evaluatie naargelang de leeftijd van de arts (jongere cardiologen, longartsen, internisten en gastro-enterologen en oudere chirurgen en orthopedisten) dan is het global genomen enkel het specialisme dat hier determinerend is (App.V.2.6.).

Vooral de neuropsychiaters, anesthesisten, kinderartsen, tysiotherapeuten, radio-radiumtherapeuten, reumatologen, gynaecologen en huisartsen verklaren gunstige ervaring te hebhen met het optreden van paramedici in eigen praxis.

De overige, in hoofdzaak technische specialismen, zijn minder gereed dit te verklaren. Uit eigen aanvullend onderzoek blijkt trouwens dat voaral zij niets specifieks vinden in het optreden van paramedici en dat zij net zo zouden handelen. Hun technische instelling sluit hier dicht an bij hun wardering van hulpkrachten wier handelingen vak overwegend technisch zijn.

8. In de academische opleiding moet het accent op de algemeen medische vorminglop specialisatie worden gelegd en in de praxis moet de psycho-sociale context (niet) worden betrokken.

Het is opvallend dat vooral jongere artsen het accent in de academische opleiding op een algemeen medische vorming gelegd wensen te zien. Dit sluit goed aan bij hun kritische houding t.a.v. hun basisopleiding. In de praxis hechten zij hovendien veel belang a an randmedische situaties. Ook het beoefend specialisme verklaart mede deze instelling (App.V.2.7.).

Uiteraard treden hier specialisten op de voorgrond die we vroeger reeds ontmot hebben als artsen die hun opleiding niet zo gunstig beoordeelden. Noemen we als meest opvallend: de jongere neuropsychiaters, huisartsen, fysiotherapeuten, radio-radiumtherapeuten, reumatologen, röntgenspecialisten en 
mondartsen, mar ook alle kinderartsen.

Samenvattend komt dit neer op een malaise in de medische opleiding die vooral jongere artsen a nvoelen. Het systeem van een te gespecialiseerde opleiding waraan zij deelnamen, laat hen best de tekorten op het $v$ lak van de menselijke contacten in de therapeutische relatie aanvolen.

Aan de andere zijde staan dan vooral de oudere artsen. Hierbij valt het op dat het om meer technische specialismen gaat. Blijkbaar oordelen zij, méer dan hun jongere collega's, dat specialisatie in termen van technische kennisverwerving wardevoller is dan een integrale benadering van de patiënt.

SAMENVATTING.

overzichtelijk kan uit de analyse per afzonderlijke variabele worden afgeleid dat, war én specialisme én leeftijó tegelijkertijd als verklarende variabele optreden, het in hoofdzaak aspecten betreft die de brede basiswarden van de medische praxis bestrijken.

Wanneer hoofdzakelijk niet-technische specialisten deze warden bijtreden, dan geldt dit toch bij voorkeur de jongeren onder hen.

Randmedische betrokkenheid, zoals deze in de eerste en zevende variabele wordt uitgedrukt, is eerder een kenmerk dat bij bepalde specialismen hoort. Voor beide variabelen scoren neuropsychiaters, huisartsen en kinderartsen boven het gemiddelde. 


\subsection{MULTIDIMENSIONELE VERKLARING.}

5.2.1. Inleiding.

Uit de attitudes en zelfevaluaties van de artsen blijkt dat, over de gehele lijn deze wardeoordelen zelden of nooit geisoleerd optreden, mar dat zij vak onderling gerelateerd zijn. Tijdens de bewerking van het onderzoekmateriaal drong zich dan ook de behoefte op meer inzicht te verwerven in de positie die de onderscheiden variabelen in het totaal krachtenveld van zowel afhankelijke als onafhankelijke variabelen innemen.

Besloten werd:

- na te gaan of er eventueel multidimensionele samenhangen bestaan tussen de eerder belichte facetten van het medisch verkeer:

- zo ja, te onderzoeken welke rol het beoefend specialisme met inachtneming van de leeftijd in die samenhangen speelt.

Het verstrekken van een meer compacte voorstelling komt neer op het opsporen van een antal dimensies door toepassing van een multidimensionele schaaltechniek.

Aangezien de vraagstelling uit hoofde van het exploratief karakter van het onderzoek veelal meerdere antwoordmogelijkheden voorziet, doch de toepassing daarop van een adequate multidimensionele schaltechniek voor niet-metrische gegevens dichotomisering van de antwoorden vereist, worden deze aldus getransformeerd (App.VI.1.) en krijgen zij derhalve een quasi-metrisch karakter.

Op basis van de berekende $\phi$-coëfficiênten (qecorrigeerd voor constant maximum), wordt een rangorde van afstanden tussen antwoordparen bekomen. Eens deze rangorde van (on)gelijkenissen tussen n-warnemingen gegeven, is het doel van het algorithme, de coordinaten te vinden van n-punten die de wa arnemingen vertegenwoordigen in een r-dimensionele ruimte en wel zodantg dat de rangorde van de afstanden tussen deze punten approximatief dezelfde is als:de rangorde van de (on)gelijkenissen. 
Gesteld dat de warnemingen $(0 t$ punten $)=f, f=1, \ldots, n$ en de coördinaten $=x_{i p}, p=1, \ldots, r$, dan zijn de afstanden fussen de punten =

$$
z_{i j}={\sqrt{\sum_{p}\left\{x_{i p}-x_{j p}\right\}^{2}}}^{2}
$$

voor $r$ punten in een $r$-dimensionele ruimte.

Doorgaans voldoen deze afstanden qua volgorde niet aan de data. Daarom wordt a an elke afstand $z_{i j}$, een getab $z_{j} t_{\text {gege- }}$ voegd dat men gelijkstelt aan die afstand $z$ die in de afstandenreeks dezelfde rangpositie bekleedt als de getijkenis $(5, j)$ in de data.

De gelijkenissen worden van groot naar klein en de afstanden van klein naar groot gerangschikt.

De getallen $z_{i j}$ noeten a twee eisen voldoen :

a zij moeten monotoon zijn met de data s d. de volgorde van. $z_{i j}^{0}$ naar algebraîsche grootte moet omgekeerd dijh abu de volgorde van de gelijkentssen tussen de punten jen j choe groter de gelijkenis, des te kleiner de afstand $\left(z^{0}\right)$ is b. die verschitlen tussen $z_{i j}$ en $z_{i j}^{0}$ moleten zo klein mogerlijkntijn. Bij een bepalde configuratie X worden aldus de $z_{j}$ (symbool $z_{i j}^{*}$ ) berekend en deze worden geanalyseerd. Iteratieft wordt naur een zo goed mogelijk passende $z_{j}^{\circ}$ gestreefd bij een wijziging van de configuratie $x$.

Als mat van badriess-of-fit geldt de Gut than-Lingoes

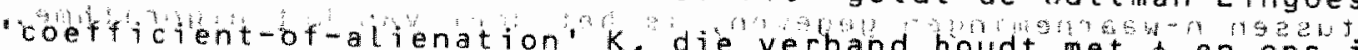
coefficient-of-alienation $K$, die verband houdt met $\phi$ en ons informeert over de mate warin er onverklaarde variantie resteert:

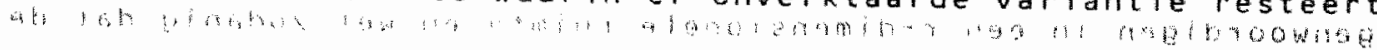

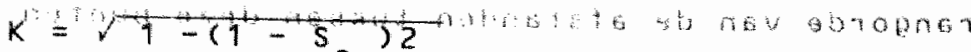

$$
\begin{aligned}
& \frac{0}{2 n} 2^{4} \text { an }
\end{aligned}
$$


Deze standaard-mat wordt gebruikt ondat $s_{0}$ een ongenormeerde mat van overeenkomst tussen configuratie en data is. De term $n^{2}$ is een substitutie voor $\sum z_{i j}^{2}$ en geldt als $z_{i j}$ een euclidische afstand is en de norm van de configuratie gelijk is aan $n$. Voor een meer uitvoerige en uiteraard mathematische uit Leg verwijzen we naar Edw.E.ROSKAM, 1975 (Zie ook App.I, $3^{\circ}$ ).

Precieze regels kunnen niet worden gegeven omtrent wat een "high coefficient of alienation" is. Als vuistregel kan echter worden beschouwd (Edw. E.Roskam, 1975) dat $K=0.210$ een matig tot goede overeenkomst tussen configuratie en data weerspieget $t$.

Uit App.VI.2 lezen we af dat $K=.210$ en de genoende overeenkomst aldus wordt bereikt.

Is deze coëfficiënt evenwel niet een absoluut criterium, mar geldt hij wel als ruggesteun voor interpretatie, dan zal toch steeds de inhoud zelf van de dimensie de beste leidraad zijn.

De resultaten van deze analyse worden, zoals hierna meer uitvoerig uiteengezet, derwijze voorgebracht dat zij de overzichtelijkheid dienen.

5.2.2. Opzet van de resultaten der analyse.

Uit de analyse zijn drie dimensies nar voren getreden (App.VI. 2 en 3).

op grond van hun coördinaten en van hun unidimensionele aanwezigheid laten een antal variabelen toe, de dimensies te omschrijuen en te benoemen. Variabelen met te kleine coördinaten worden hierbij geweerd, daar zij 'slechts' contextueel van belang zijn. Dit mag echter op geen enkele wijze een ujtnodiging zijn ze te verwarlozen, daar zij een integrerend deel van de betrokken dimensie zijn en er bovendien aan herinneren dat het medisch verkeer moejlijk in streng afgebakende gebieden kan gezien worden. Integendeel, het verschijnt voortdurend als een interdependent geheel.

Het is in deze gedachtengang dat achtereenvolgens de di- 
mensies worden omschreven en benoend en nadien worden geinterpreteerd op de verschillen die specialismen en leeftijd als mest verklarende factoren dicteren (5.2.3.). Gezien leeftijd en specialisme simultaan de dimensionele perceptie van de arts beinvloeden, wordt in de hiernavolgende deelhoofdstukken een gedetailleerd beeld verstrekt van de afzonderljjke invloed van beide variabelen. De cijferkundige resultaten van de analyse worden in Appendix V1.4.4. tot VI.4.9. gebracht, daar zijals basisinformatie van enig nut kunnen zijn.

Door het gelijktijdig beschouwen van beide basisvariabelen ondergaan zowel de rangorde der specialismen binnen de leeftijdscategorieën als de generatieverschillen binnen elk specialisme enige transformatie. De rangpositie die jongere en oudere specialisten innemen wordt onderzocht in functie van het geheel der respondenten. Dit heeft tot gevolg dat jongere en oudere artsen per specialisme afzonderlijk worden beschouwd en we alsdan een rangorde krijgen over $14 \times 2$ subcategorieën.

Aangezien rangorden van enige omvang als deze zich

moeilijk tot interpretatie lenen, geven we ze een meer compacte structuur door ze in drie scoreniveaus in te delen : hoog, middel, Laag met respectievelijke frequenties van negen, tien en negen subcategorieën.

zoals reeds hoger vermeld worden ook hier ter vergelijkbaarheid der resultaten de ruwe scores omgezet in standaardscores.

Gebruik wordt gemakt van de formule:

$$
\gamma_{j l}=\sum_{i=1}^{k} \frac{\bar{x}_{i j}-m_{i}}{o_{i}} \times c_{i L}
$$

warbij $k=$ aantal veranderlijken met coördinaten $\left(c_{i}\right)$ voor djmensie $l ; j=a r t s e n c a t e g o r i e$.

onder 5.2 .4 wordt het medisch verkeer interdimensioneel belicht door de rangorde die de specialismen (per leeftijdscategorie ingedeeld) binnen de drie dimensies innemen, te vergelijken. 
Een totalbeeld (5.2.5) van de drie dimensjes moet ons verder toelaten te wijzen op vaste vormen die bepalde disciplines vooralsnog hebben aangenomen, anderzijds op tendenzen die in andere specialismen duiden op veranderbaarheid van het medisch verkeer.

5.2.3. De drie dimensies.

1. Eerste dimensie : individualistische hulpverlening.

a. Omschrijuing en Benoeming (App.VI.4.1)

Deze dimensie kenmerkt de arts als een overtuigd voorstander van de individuele praxis (variabele 1 ) die niet het genezen, mar het helpen van de patiënt als zijn belangrijkste taak ziet (variabele 2). Op het sociaal vlak van zijn praxis weet deze arts zich duidelijk te situeren en verklaart bovendien expliciet, reeds gunstige ervaring gehad te hebben met het optreden van paramedische hulpkrachten in eigen praxis (variabele 3 ). De academische opleiding die hijgenoot, beoordeelt hijals alLesbehalve adequat (variabele 4).

Deze arts biedt zich aan als de solitaire wachter in permanent conflict met zichzelf en mediterend over de relativiteit van de klassieke beschrijuing van vele aandoeningen.

Geconfronteerd met kwalen als een moeilijke spijswertering, een hoofdpijn, een vage pijn in de lenden of rug warmee het onaangenaam is te leven, onderkent deze individualist $z$ ichzelf niet als een mirakeldoener, voorspelt geen termijn voor herstel, poogt niet te overtuigen met goedgevulde voorschritten of voegt ook geen nieuwe a andoening toe als voorwendsel om de klagende te verlossen van die klachten die hij reeds heeft. Binnen zijn bevoegdheid en binnen zijn consultatieruimte weet hij, mede door zijn extra-medische, dus randmedische belangstelling, vertrouwen te creëren en, wanneer nodig, beroep te doen op meer bevoegde hulpkrachten.

Intermediaire gevallen daargelaten, staan a an de overzijde de.groeps- en teamgerichte genezers, met een conceptie van 
de zieke als een individu met een ziekte die moet genezen worden.

b. Rangorde.

In de hiernavolgende tabel staan, met een abnormal hoge score, de jonge anesthesisten aan de top. Numeriek klein in aantal, vormen zij een te grote witschieter, om bij de interpretatie te kunnen worden betrokken.

uit reeds eerder vermelde resultaten weten we dat neuropsychiaters en huisartsen zich duidelijk als individualisten hebben afgetekend. Dit doen zjj in deze eerste dimensie ook. Als disciplines in hun geheel scoren beide hoog. De leeftijd van de betrokkenen speelt hierbij geen rol. Zij zijn bijuitstek specialisten (1) die in het uitsluitend individueel contact met de patient een garantie zien voor het tot stand komen van een hechtere arts-patiënt binding. Zij zijn er zich duidelijk van bewust dat, door het bewerkstelligen van een relatie van vertrouwen, de patiënt reeds voor een deel geholpen is, wat voor hem een primair gegeven is.

Een hoge score bereikt verder ook de jongere generatie van de kinderartsen, mondartsen, fysiotherapeuten, radio-radiumtherapeuten en reumatologen.

Voor de kinderartsen kan dit duiden op een evolutie naar een betere a anpak van de ouder-kind relatie in de aanbiedingen, war de aandacht niet enkel naar het kind wordt gericht.

(1) Om heel wat redenen wordt ook hier de kwalificatie 'specialist' aan de huisarts toegekend. 
Tabel 9. 1e DIMENSIE : Individualistische hulpvertenina.

Rangorde die de onderscheiden specialismen, ingedeeld naar leeftijdscategorieèn, in de eerste dimensie innemen.

\begin{tabular}{|c|c|c|c|c|}
\hline Rang & Specialisme & Leeftijd & $\begin{array}{c}\text { Gemiddelde } \\
\text { score }\end{array}$ & \\
\hline 1 & Anesthesisten & (d) & +20.378 & \\
\hline 2 & Kinderartsen & (J) & +5.895 & \\
\hline 3 & Mondartsen & (J) & +3.229 & \\
\hline 4 & Neuropsychiaters & (J) & +3.181 & Hoog \\
\hline 5 & Huisartsen & (j) & +2.398 & \\
\hline 6 & Neuropsychiaters & (0) & +1.818 & \\
\hline 7 & Huisartsen & (0) & +1.263 & \\
\hline 8 & Gynaecologen & $(0)$ & +0.799 & \\
\hline 9 & Fys., rrth., reumat. & (J) & +0.447 & \\
\hline 10 & Gynaecologen & (J) & -0.090 & \\
\hline 11 & Dermatoven., urol. & $(0)$ & $-0.64 ?$ & \\
\hline 12 & Kinderartsen & $(0)$ & -0.962 & \\
\hline 13 & Cardial. , Longarts. & $(J)$ & -1.251 & \\
\hline 14 & Chirurg., orthoped. & $(0)$ & -1.438 & \\
\hline 15 & Intern.,gastro-ent. & $(J)$ & -1.542 & Middel \\
\hline 16 & Dermatoven., urol. & $(J)$ & -1.726 & \\
\hline 17 & Chirurg., orthoped. & (J) & -1.774 & \\
\hline 18 & Cardiol., longarts. & $(0)$ & -1.836 & \\
\hline 19 & Keel-neus-oor,oog. & (0) & -1.985 & \\
\hline 20 & Mondartsen & (0) & -2.088 & \\
\hline 21 & Klin.biologen & $(J)$ & -2.2 .39 & \\
\hline 22 & Röntgenspecialisten & (J) & -2.443 & \\
\hline 23 & Keel-neus-oor,oog. & (J) & -2.783 & \\
\hline 24 & Intern., gastro-ent. & $(0)$ & -2.914 & $\operatorname{Lag}$ \\
\hline 25 & Fys., rrth., reumat. & $(0)$ & -3.065 & \\
\hline 26 & Anesthesisten & $(0)$ & -3.202 & \\
\hline 27 & Röntgenspecialisten & (0) & -4.477 & \\
\hline 28 & Klin.biologen & (0) & -4.518 & \\
\hline
\end{tabular}


SCHEMA I. INDIVIDUALISTISCHE HULPUERLENING.

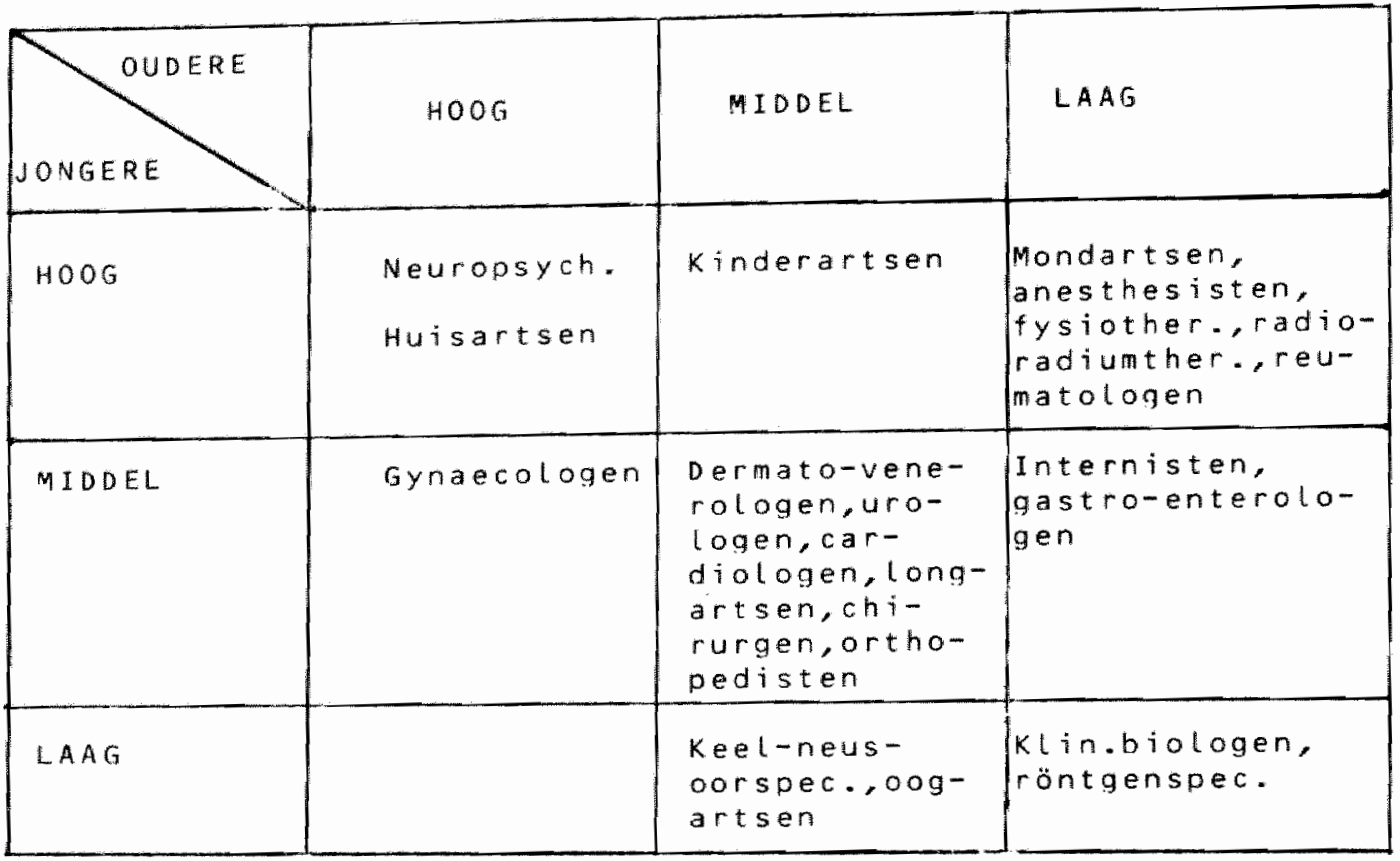

Meer dan zijn oudere collega's blijkt de jongere kinderarts in de eerste plats te helpen en is hijer zich van bewust dat op het sociaal-psychologisch vlak van zijn praxis belangrijke opdrachten te vervullen zijn.

over zijn opleiding aan de universiteit en specifiek over zijn specialistische opleiding wit hij felle kritiek. De massale aangroej in dit spectalisme is hier wellicht niet vreemd aan.

Voor de jongere mondartsen moet enige reserve gesteld worden daar zij duidelijk minimal vertegenwoordigd zijn. De jongere fysiotherapeuten, radio-radiumtherapeuten en reumatologen onderscheiden zich scherp van hun oudere collega's die laag scoren. Revalidatie is niet zo lang terug een a anvard terrein ge- 
worden in de gezondheidszorg wat mede een verklaring vormt voor de sterke aangroei van genoemde specialisten.

Deze disciplines worden gekenmerkt door vak langdurige behandelingen die niet enkel op louter medisch vak, maar ook op psycho-sociaal vlak voldoende lang moeten worden geprolongeerd om de patiënt te herstellen, zijn invaliditeit te verminderen of om minder valiede individuen op de voor hen best geschikte plaats in de matschappij te reintegreren. Dit voaronderstelt zo niet een continue inzet van de arts zelf, dan toch een continue supervisie over en begeleiding van de voorgeschreven behandelingen, die zij aan paramedische hulpkrachten opdragen. Blijkbaar zien de jongere beoefenaren van deze specialismen gevoelig meer dan hun audere collega's deraelijke continue zorg enkel realiseerbaar binnen het kader van een individuele praxis.

Van de overige specialismen zijn het enkel de oudere gynaecologen die hoger scoren dan hun jongere collega's. De ouderen stappen vermoedelijk niet zo gemakkelijk af van de integrale en continue zorg aan hun patienten. Jongere artsen in dit specialisme delegeren immers heel wat van hun taken aan bvb. gediplomeerde vroedvrouwen in ziekenhuisverband; zij worden trouwens zo opgeleid.

Global valt het op dat er meer jongere artsen hoog scoren. Zij interpreteren dan het medisch verkeer meer vanuit de persoonlijke relatie met de patient, eeruer dan vanuit een traditioneel professioneel concept, war zich de oudere qeneratie a an hecht. Deze verhouding wordt gereflecteerd in de lagere scores, war zich meteen ook als entiteiten de zeer technisch geörienteerde $k l i n i s c h e$ biologen en röntqenspecialisten onderscheiden die, zo niet in ziekenhuisverband werken, dan toch in hun werkzaamheden onmiddellijk afhankelijk zijn van andere medische opdrachtgevers.

Tenslotte noteren we nog de dermato-venerologen, urologen, cardiologen, longartsen, chirurgen en orthopedisten. zij zijn de specialisten die weinig opvallen en de middengroep 
bezetten, war zowel de jongere als de oudere artsen uit deze specialismen thuishoren.

2. ?e DIMENSIE : Integrale geneeskunde.

a. Omschrijuing en Benoeming (App.VI.4.2)

Deze dimensie benadrukt dat in de opleiding het accent op een algemeen medische vorming moet worden gelegd, eerder dan op het verwerven van specialistische kennis. In de praxis zelf zet de arts zich beter in op het psycho-sociale vlak van de aandoening, eerder dan op technische vervolmaking (variabele 2 ). Randmedische informatie inwinnen moet dan ook beschouwd worden als een routineaangelegenheid (variabele 1 ). Samen met de resterende variabelen die er bij aansluiten, kan het paradoxaal heten dat deze dimensie het beeld aproept van de moderne arts die de integrale benadering van de patiënt nastreeft, daar waar hij in feite de traditionele geneeskunde, zoals voorgehouden door Hippokrates, huldigt. Hij kijkt sceptisch aan tegen de alwetendheid van een elektro-cardiogram of een elektro-encephalogram of een elektronische verpleegster. Kortom hij wantrouwt de 'afstandbediende' geneeskunde die nar zijn oordeel niet alles vermag. Deze artsen voelen niet enkel, maar ervaren dat pure wetenschap hen van de zieke persoon heeft weggehald. $z i j$ weten dat een affectieve shock, asthma of een magaandoening kan veroorzaken. Ze weten ook dat een variëteit van leefsituaties niet enkel hun verhal krijgen in het consultatiekabinet van de psychiater, mar ook al dan niet via deze, de klagende naar hun discipline brengt.

Door hun begrijpende instelling geven $z i j$ aan hun praxis een persoonlijk karakter, evenwel zonder de wetenschappelijke reikwijdte van de moderne geneeskunde te minimaliseren.

De andere pool ziet met ontzag op naar een eindeloze rij van specialisten, waartoe zij ook zichzelf rekenen. In ziekenhuisverband krijgt een 'mooi geval' het voorrecht, veel langer dan een 'gewoon geval', het défilé van heel wat specialisten 
en begeleidende stagiaires te a anschouwen. Onderzoek, injecties, laboratoriatesten bevredigen de zucht naar kennis en zekerheid. Technologische innovaties worden op de voet gevolgd.

b. Rangorde.

Bij deze dimensie mag niet worden voorbijgegaan aan de rang die de anesthesisten in hun geheet innemen. Al is de score van de jongere anesthesisten om hoger reeds vermelde redenen als een uitschieter te nemen, dan worden zij in tweede rang toch gevolgd door hun oudere collega's.

Blijkbaar zien zij het chirurgisch-technisch gebeuren niet geisoleerd, mar bouwen het in een psycho-sociale context in, wat uit het geheel der variabelen bij deze dimensie af te leiden is.

Hoge scores worden ook behald door:

- jongere kinderartsen, röntgenspecialisten en neuropsychiaters;

- oudere huisartsen, chirurgen, orthopedisten, dermato-venerologen, urologen en mondartsen.

Die integrale instelling bij jonge pediaters en neuropsychiaters is goed te verklaren vanuit hun specialisme, maar ook hier is de leeftijd van invloed. Bij hun kritische instelling (dit weten we reeds) t.a.v. het gebrek aan aandacht in de opleiding voor psychische, sociale en emotionele factoren, sluiten alle overige variahelen onmiddellijk aan. Hun oudere collega's formuleerden heel wat minder dergelijkekritieken.

Wellicht leggen oudere kinderartsen gemakkelijker kleine noden en wensen van klager enfof a anbieder opzij en beschouwen ze deze als ballast van het symptoom dat hen voldoende verklaring biedt. Trouwens hun niet zo hoge score in de eerste dimensie kan bij deze overweging aanleunen.

Voor de oudere neuropsychiaters kan ook die redenering gelden, mar dan eerder op grond van een meer beperkte denkruimte in voorgehouden psychiatrische ziektebeelden, terwijt de laatste decennia vooral allerlei sociale conditioneringen worden benadrukt. 
Tabel 10. 2e DIMENSIE: Integrale geneeskunde.

Rangorde die de onderscheiden specialismen, ingedeeld nat leeftijdscategorie, in de tweede dimensie innemen.

\begin{tabular}{|c|c|c|c|c|}
\hline Rang & Specialisme & Leeftijd & $\begin{array}{c}\text { Gemiddelde } \\
\text { score }\end{array}$ & \\
\hline 1 & Anesthesisten & $(d)$ & +14.893 & \\
\hline 2 & Anesthesisten & $(0)$ & +5.895 & \\
\hline 3 & Kinderartsen & (J) & +1.383 & \\
\hline 4 & chirurg. or thoped. & (0) & +1.233 & \\
\hline 5 & Huisartsen & $(0)$ & +0.988 & $\mathrm{HOOg}$ \\
\hline 6 & Dermatoven.,urol. & $(0)$ & +0.688 & \\
\hline 7 & Rontgenspecialisten & $(d)$ & +0.607 & \\
\hline 8 & Neuropsychiaters & (J) & +0.111 & \\
\hline 9 & Mondartsen & $(0)$ & +0.091 & \\
\hline 10 & Keel-neus-oor,oog. & $(\mathrm{J})$ & +0.048 & \\
\hline 11 & Fys., rrth., reumat. & (0) & $-0.04 ?$ & \\
\hline 12 & Gynaecologen & (0) & -0.064 & \\
\hline 13 & Intern., gastro-en:. & (d) & -0.187 & \\
\hline 14 & Gynaecologen & (J) & -0.348 & MiddeL \\
\hline 15 & Klin.biologen & $(\mathrm{J})$ & -0.364 & \\
\hline 16 & Huisartsen & (J) & -0.563 & \\
\hline 17 & Röntgenspecialisten & (0) & -0.736 & \\
\hline 18 & KLin.biologen & $(0)$ & -0.749 & \\
\hline 19 & Intern. gastro-ent. & $(0)$ & -0.770 & \\
\hline 20 & Neuropsychiaters & $(0)$ & -0.864 & \\
\hline 21 & Kinderartsen & (0) & -0.972 & \\
\hline 22 & Fys., rrth., reumat. & (J) & -0.995 & \\
\hline 23 & Chirurg. or thoped. & (J) & -1.348 & \\
\hline 24 & Keel-neus-oor,oog. & $(0)$ & -1.813 & Laag \\
\hline 25 & Cardiol. Longarts. & (j) & -3.156 & \\
\hline 26 & Mondartsen & $(J)$ & -3.514 & \\
\hline 27 & Dermatoven. orol. & $(J)$ & -3.967 & \\
\hline 28 & Cardiol. longarts. & $(0)$ & -6.299 & \\
\hline
\end{tabular}


SCHEMA I I INTEGRALE GENEESKUNDE.

\begin{tabular}{|c|c|c|c|}
\hline JONGERE & HoOG & MIDDEL & $\angle A A G$ \\
\hline HOOG & Anesthesisten & Röntgenspec. & $\begin{array}{l}\text { Kinderartsen } \\
\text { Neuropsychia- } \\
\text { ters }\end{array}$ \\
\hline MIDDEL & Huisartsen & $\begin{array}{l}\text { Gynaecologen, } \\
\text { Internisten, } \\
\text { Gastro-entero- } \\
\text { logen,klin. } \\
\text { biologen }\end{array}$ & $\begin{array}{l}\text { Keel-neus-oor- } \\
\text { spec. oogartsen }\end{array}$ \\
\hline LAAG & $\begin{array}{l}\text { Chirurgen, or- } \\
\text { thopedisten, } \\
\text { urologen, } \\
\text { mondartsen }\end{array}$ & $\begin{array}{l}\text { Fysiotherapeu- } \\
\text { ten, radio-ra- } \\
\text { diumtherapeu- } \\
\text { ten, reumatolo- } \\
\text { gen }\end{array}$ & $\begin{array}{l}\text { Cardiologen, } \\
\text { longartsen }\end{array}$ \\
\hline
\end{tabular}

AL beheerst de röntgenspecialist "slechts" ến enkele techniek of beperkt hij zich tot het deskundig bedienen van é̉n apparat, wat hem van de echte geneesheer-specialist onderscheidt, dan toch wijst de jongere generatie deze eenzijdige interesse van de hand. Hun kritiek op de genoten opleiding andersteunt deze instelting.

Is integrale zorg eigen aan de huisarts en veronderstelt dit meteen continuiteit van de zorg (follow-up), dan toch zijn het de ouderen onder hen die het best aan deze dimensie beantwoorden. Niet enkel de maturiteit kan als verklaring ingeroepen worden, mar ook de nieute medische constellatie van de versnippering van de geneeskunde, warin de figuur van de nochtans even - zo niet méér - noodzakelijke traditionele gezinsarts plaats moet maken voor de aldus opgeleide figuur van de generalist.

op dit hoge scoreniveau verschijnen ook de oudere chirur- 
gen, orthopedisten, dermato-venerologen, urologen en mondartsen. wanneer hun rangpositie binnen de leeftijdscategorie hoger is dan die van hum jongere collega's, wordt dit onmiddellijk geaccentueerd door het generatieverschil binnen het specialisme zelf. Hoewel zijalle technische specialisten zijn, dan laat zich toch de invloed van verder doorgedreven specialisatie op medisch-tecknisch vlak sterker voelen bij jongeren, die blijkbaar minder aandacht opbrengen voor de periferie van de zieke als persoon.

Opvallend tenslotte is de positie die de cardiologen en Longartsen bekleden. Op een paar uitzonderingen na c $z i j$ scoren hoog op de preventieve instelling en getuigen van een duidelijke zelfevaluatie in de informatieve rolcomponent treden deze specialisten door hun lage score dermate op de voorgrand dat zij moejlijk als integraal ingestelde artsen kunnen worden gekarakteriseerd. 0ok hier kan geopperd worden dat zij zich vooral medisch-technisch richten.

3. 3e DIMENSIE : wardering van gekwalificeerde hulpkrachten.

a. Onschrijuing en Benoeming (App.VI.4.3)

In deze dimensie wordt het inwinnen van randmedische informatie als een uitdrukkelijke opdracht van bevoegde hulpkrachten gezien (variabele 1). Het optreden van dezen in de praxis wordt als gunstig ervaren (variabele 4). Bij dergelijke instelling hoort ook het voorlichten van de patiënt (variabele 2 ), het inlichten var de patient (variabele 3 ) en het routinematig inwinnen van randmedische informatie. De hierbij betrokken artsen identificeren $z i c h$ bovendien duidelijk in de onderscheiden rolcomponenten.

In het geheel predomineert, duidelijk afgescheiden met hoge lading, de erkenning in het medisch gebeuren van de gekwalificeerde hulpkracht. Uit de verdere wardering voor het optreden van deze hulpkrachten in eigen praxis en ook uit meer gedetailleerd eigen onderzoek omtrent de specificiteit van dit optre- 
den blijkt, dat zij in de samenwerking het element 'complementariteit' onderkennen, dus niet een verhouding dominant-gedomineerde. $z i j$ kennen aldus een eigen autonomie en eigen bestissingsrecht toe aan deze krachten, waruit mag worden verondersteld dat $z i j$ hun delegerende opdrachten 'verzorgen'.

Lag scoren betekent dat de arts in het medisch gebeuren het zwartepunt bezet, dus dat hij de hulpkrachten enkel ziet als een 'functioneel raderwerk'. Geörienteerd op het technisch aspect van zijn diagnostisch en therapeutisch werk, gunt hij zich niet altijd de tijd de randmedische aspecten van zijn beroepsuitoefening te verzorgen, mar laat hij die zorg op de schouders rusten van de hulpkrachten die allerlei psycho-affectieve problemen van de patient moeten opvangen.

b. Rangorde.

Alle huisartsen, fysiotherapeuten, radio-radiumtherapeuten en reumatologen scoren hoog.

De eersten doen courant beroep op familiale helpsters en onderhouden frequent contact met medico-sociale diensten. De anderen - en dit hoort bij hun discipline - doen beroep op meer technisch gevormde hulpkrachten, zoals ergo-therapeuten, kinesitherapeuten e.d., wat niet betekent dat zij het ziektebeeld in hun disciplines los zien van de psycho-sociale context. Ten aanzien van de huisartsen duidt het verschil in de soort hulpkrachten hier enkel op een echelonverschil.

Hoog scoren ook de jongere neuropsychiaters en kinderartsen, hoewel de oudere neuropsychiaters vooraan in de middenklasse liggen. De jongere anesthesisten komen om hoger vermelde redenen andermal niet in aanmerking. 
Tabel 11. 3e DIMENSIE: Wardering van gekwalificeerde hulokrachten.

Rangorde die de onderscheiden specialismen, ingedeeld naar leeftijdscategorie, in de derde dimensie innemen.

\begin{tabular}{|c|c|c|c|c|}
\hline Rang & Specialisme & & $\begin{array}{c}\text { Gemiddelde } \\
\text { score }\end{array}$ & \\
\hline 1 & Anesthesisten & (J) & +17.629 & \\
\hline 2 & Kinderartsen & (J) & +3.329 & \\
\hline 3 & Neuropsychiaters & (J) & +2.441 & \\
\hline 4 & Huisartsen & (j) & +1.175 & \\
\hline 5 & Gynaecologen & (0) & +0.787 & Hoog \\
\hline 6 & Chirurg. or thoped. & $(0)$ & +0.677 & \\
\hline 7 & Fys., rrth., reumat. & (J) & +0.541 & \\
\hline 8 & Fys. .rrth., reumat. & (0) & +0.453 & \\
\hline 9 & Huisartsen & (0) & +0.450 & \\
\hline 10 & Dermatoven., urol. & (j) & -0.055 & \\
\hline 11 & Neuropsychiaters & (0) & -0.409 & \\
\hline 12 & Intern. gastro-ent. & (J) & -0.438 & \\
\hline 13 & Mondartsen & (J) & -0.501 & \\
\hline 14 & Cardiol . Longarts. & (J) & $-0.5 ? ?$ & \\
\hline 15 & Dermatoven.,urol. & (0) & -0.565 & Middel \\
\hline 16 & Gynaecologen & (J) & -0.878 & \\
\hline 17 & Röntgenspecialjsten & $(0)$ & -0.980 & \\
\hline 18 & chirurg., or thoped. & $(\mathrm{J})$ & -1.116 & \\
\hline 19 & Mondartsen & $(0)$ & -1.308 & \\
\hline 20 & Klin.biologen & $(\mathrm{J})$ & -1.454 & \\
\hline 21 & Anesthesisten & $(0)$ & -1.520 & \\
\hline 22 & Kinderartsen & (0) & -1.711 & \\
\hline 23 & Intern.,gastro-ent. & $\cos$ & -1.783 & \\
\hline 24 & Keel-neus-oor,oog. & $(0)$ & -1.838 & Laag \\
\hline 25 & Röntgenspecialisten & (d) & -1.906 & \\
\hline 26 & Cardiol. Longarts. & $(0)$ & -2.409 & \\
\hline 27 & Klin.biologen & (0) & -2.532 & \\
\hline 28 & Keel-neus-oor, oog. & (J) & -4.921 & \\
\hline
\end{tabular}


SCHEMA III. WAARDERING VAN GEKWALIFICEERDE HULPKRACHTEN.

\begin{tabular}{|c|c|c|c|}
\hline JONGERE & HOOG & MIDDEL & LAAG \\
\hline HOOG & $\begin{array}{l}\text { Huisartsen } \\
\text { Fysiothera- } \\
\text { peuten, radio- } \\
\text { radiumthera- } \\
\text { peuten, reu- } \\
\text { matologen }\end{array}$ & $\begin{array}{l}\text { Neuropsychia- } \\
\text { ters }\end{array}$ & $\begin{array}{l}\text { Kinderartsen } \\
\text { anesthesisten }\end{array}$ \\
\hline MIDDEL & $\begin{array}{l}\text { Gynaecolo- } \\
\text { gen, chirur- } \\
\text { gen, artho- } \\
\text { pedisten }\end{array}$ & $\begin{array}{l}\text { Dermato-vene- } \\
\text { rologen, urolo- } \\
\text { gen, mondartsen }\end{array}$ & $\begin{array}{l}\text { Internisten, } \\
\text { gastro-ente- } \\
\text { rologen, car- } \\
\text { diologen, } \\
\text { longartsen }\end{array}$ \\
\hline LAAG & & $\begin{array}{l}\text { Röntgenspe- } \\
\text { cialisten }\end{array}$ & $\begin{array}{l}\text { Klinische bio- } \\
\text { logen, keel- } \\
\text { neus-oorspecia- } \\
\text { listen, oogart- } \\
\text { sen }\end{array}$ \\
\hline
\end{tabular}

De afstand tussen jongere en oudere kinderartsen daarentegen is opmerkelijk groot. Veranderingen in het opleidingssysteem, dat vroeger minder en bij de jongere generatie in zeer ruime mate gekwalificeerd personeel en diensten inschakelt, anders gezegd,sterke rationalisatie, kan dit verschil verklaren.

onder de oudere artsen scoren de gynaecologen, chirurgen en orthopedisten hoog. In deze discipline worden de beoefenaren geconfronteerd met onbetwistbaar belangrijke momenten warin zij, gezien hun leeftijd, tot groter zelfbegrip en tot intenser begrijpen komen van de problemen van de patiënt. De verwachtingen en de eisen die zij a an hulpkrachten stellen, zullen dan ook wél hoog zijn. Hun wardering voor dezen sluit hier bij a an.

Klinische biologen, keel-, neus- en oorspecialisten en oogartsen scoren allen laag. De eersten wenden wel technisch gevormde hulpkrachten aan (laboranten), maar hun functie als scha- 
kel tussen arts en patient is onbestaand, voor zover de schakel zelf niet onbestaand is.

De anderen zijn duidelijk vakspecialisten. Voor zaver zij gekwalificeerde hulpkrachten aanwenden, blijft hun tussenkomst ondergeschikt aan een hï̈rarchisch en directief systeem van hulpverlening. Tot deze categorie behoren de jongere röntgenspecialisten en de oudere internisten, gastro-enterologen, cardiologen en longartsen. 
5.2.4. Interdimensionele rangorde.

Uit de resultaten van de profilering van de artsenwereld in drie dimensies blijkt dat beoefend specialisme en leeftijd om de beurt een rol spelen in de evaluatie van de praxis. Na dergelijke analyse blijft echter de vraag bestan of de uitkomsten nog verder kunnen worden samengevat, anders gezegd of er nog meer fundamentele structurering magelijk is. Het komt dan ook zinvol voor na te gaan hoe en in welke mate de drie dimensies samenhangen, door ze interrelationeel te belichten.

De hiernavolgende tabel verstrekt de rang die de onderscheiden specialisten, ingedeeld naar leeftijdscategorie, in de drie dimensies innemen.

Tabel 12 .

\begin{tabular}{|c|c|c|c|c|c|c|}
\hline \multirow[t]{3}{*}{ Specialisme } & \multicolumn{3}{|c|}{ Jongere artsen } & \multicolumn{2}{|c|}{ Oudere } & $\operatorname{tsen}$ \\
\hline & rana & in & nsie & rang & in & mensie \\
\hline & I & II & I I I & I & I I & I I I \\
\hline Anesthesisten & 1 & 1 & 1 & 8 & 3 & 9 \\
\hline Klin.biologen & 8 & 3 & 8 & 13 & 12 & 12 \\
\hline Card. + longartsen & 9 & 12 & $1 ?$ & 6 & 14 & 13 \\
\hline chir.torthoped. & 11 & 8 & 10 & 9 & 5 & 2 \\
\hline Derm.ven.turolog. & 12 & 11 & 6 & 5 & 10 & 14 \\
\hline Intern. + gastro. & 10 & 5 & 7 & 11 & 13 & 10 \\
\hline Gynaecologen & 7 & 6 & 11 & 2 & 8 & 1 \\
\hline Neuropsychiaters & 4 & 4 & 2 & 1 & 4 & 5 \\
\hline $\begin{array}{l}\text { Keel-, neus-, oor- } \\
\text { spec.toogartsen }\end{array}$ & 14 & 13 & 14 & 4 & 6 & 8 \\
\hline Kinderartsen & 2 & 2 & 4 & 7 & 11 & 11 \\
\hline $\begin{array}{l}\text { Fys.trad.rad. th. } \\
\text { reumatologen }\end{array}$ & 6 & 10 & 5 & 12 & $?$ & 3 \\
\hline Röntgenspec. & 13 & 9 & 13 & 14 & 9 & 7 \\
\hline Mondartsen & 5 & 14 & 9 & 10 & 1 & 6 \\
\hline Huisartsen & 3 & 7 & 3 & 3 & 7 & 4 \\
\hline
\end{tabular}


Uit de rangcorrelatie blijkt als algemene vaststelling, dat er tussen jongere en oudere artsen grondige verschilLen bestaan in de conceptie van de medische praxis. Anders gezegd, interdimensioneel getuigen de jongere artsen van een vrij duidelijke homogene visie, wat uit het uitgesproken confluent beeld van de onderscheiden confrontaties naar voren treedt. Dit is niet zo voor oudere artsen. Hun conceptie van de praxis is meer genuanceerd of beter, vertoont niet die homogene structuur die de jongeren kenmerkt.

Naar de inhoudelijke betekenis van de dimensies kunnen dan volgende vaststellingen worden afgeleid.

Bij de jongere artsen sluit een individualistisch gerichte praktijkconceptie (dimensie I) best aan bij een integrale benadering van de patiënt (dimensie II) $(p: 0.56)$. war deze individualistische instelling verder ook anleunt bij een positieve evaluatie van paramedische hulpkrachten (dimensie III) ( $\rho: 0.79$ ) zien we eveneens dat een integrale benadering van de patiënt een positieve instelling ten aanzien van de hulpkrachten impliceert $(\rho: 0.62)$.

omgekeerd, zal een meer team- of groepsgerichte visie over de medische praktijkvoering bij jongere artsen eerder aanleunen bij een technisch-wetenschappelijke opvatting, mede met een evaluatie van gekwalificeerde hulpkrachten, die zich beperkt tot hun functionele warde.

Tegenover deze duidelijke congruentie bij de jongere artsen staan de scherpe divergenties voor hun oudere collega's.

Behoudens enkele uitzonderingen (neuropsychiaters, keel-, neus- en oorspecialisten, oogartsen en huisartsen) sluit de voorkeur van de oudere artsen voor een individualistische praktijkvoering (dimensie $I$ ) in het geheel niet aan bij een integrale aanpak van de patiënt (dimensie II) ( $0: 0.07$ ) en evenmin worden de paramedische hulpkrachten door deze oudere individualisten hoog gewardeerd (dimensie III) ( $0: 0.17)$.

We stellen vast dat, wanneer oudere chirurgen, orthopedisten, fysiotherapeuten, radio-radiumtherapeuten, reuma- 
tologen en mondartsen er dan toch een integrale medische praktijkvisie op nahouden (dimensie II), zij wel geneigd zijn de paramedische infrastructuur nar warde te schat ten (dimensie III) ( $\rho: 0.64)$. Omgekeerd echter, gat een engere praktijkvisie van de oudere klinische biologen, cardiologen, longartsen, dermato-venerologen, urologen, internisten, gastro-enterologen, kinderartsen en röntgenspecialisten gepaard met een onderwardering van de gekwalificeerde hulpkracht. Alle deze oudere specialisten geven blijk van een medischtechnische praktijkvisie en deze valt samen met een erkennen van de paramedische wereld enkel als een schakel in het funotioneel raderwerk van de medische praktijkvoering.

In dit geheel nemen de oudere groeps- of teamgerichte klinische biologen, internisten, gastro-enterologen en kinderartsen een in het oog springende plaats in. Zij streven geenszins een integrale benadering van de patient na en evenmin geven zijer blijk van een grote betekenis te hechten aan paramedische tussenkomsten in hun praxis.

Tenslotte kan nu ook door somering van de afzonderlijke scores binnen de drie dimensies een totalstructuur per specialisme naar leeftijdscategorie worden bekomen. Hieruit kan de rangorde die jongere en oudere artsen innemen worden opgebouwd.

Kendall's $W$ en de $x^{2}$-toets toegepast op die rangorden, geven volgende resultaten:

$$
\text { Kendall's } w \quad x^{2} \quad d f \quad p
$$

$\begin{array}{lllll}\text { jongere artsen } & 0.77 & 30.05 & 13 & 0.01 \\ \text { oudere artsen } & 0.46 & 17.97 & 13 & <0.10\end{array}$

waruit des te sterker naar voren treedt dat, binnen de grenzen van het geheel der beschouwde dimensies, de praktijkvisie van de jongere artsen duidelijk een meer homogeen patroon vertoont dan de praktijkvisie van hun oudere collega's. 
5.2.5. Schematische voorstelling van de totalstructuur per specialisme naar leeftijdscategorie.

Op grond van de gemiddelde scores over de drie dimensiet, kunnen de onderscheiden specialismen, ingedeeld naar leeftijdscategorie, in een rangorde worden geplaatst (tabel 13 ). Dit totalbeeld, ingedeeld in drie scoreniveaus, wint aan duidelijkheid in Schema IV.

Tabel 13. Rangorde die de onderscheiden specialismen, ingedeeld naar leeftijdscategorte, in het totalbeeld van de drie dimensies innemen.

\begin{tabular}{|c|c|c|c|c|}
\hline Rang & Specialisme & Leeftijd & $\begin{array}{c}\text { Gemiddelde } \\
\text { score }\end{array}$ & \\
\hline $\begin{array}{l}1 \\
2 \\
3 \\
4 \\
5 \\
6 \\
7 \\
8 \\
9 \\
10 \\
11 \\
12 \\
13 \\
14 \\
15 \\
16 \\
17 \\
18 \\
19 \\
20 \\
21 \\
22 \\
23 \\
24 \\
25 \\
26 \\
27 \\
28\end{array}$ & 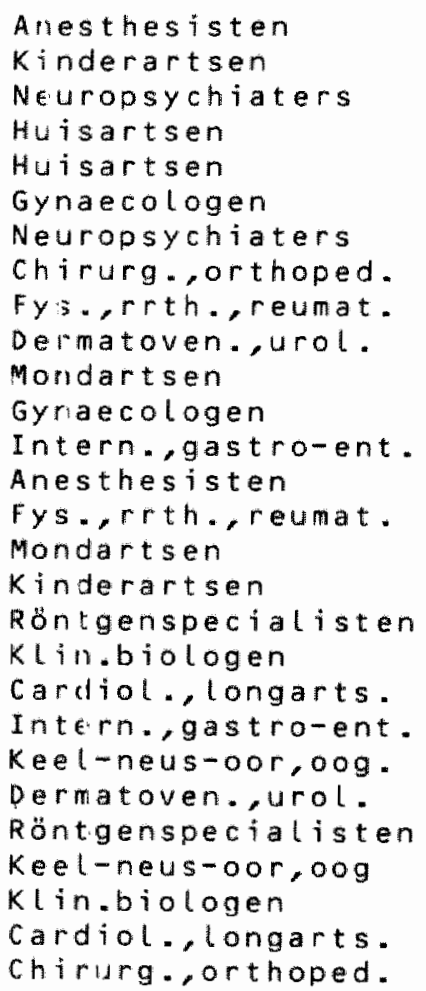 & $\begin{array}{l}(J) \\
(J) \\
(J) \\
(0) \\
(0) \\
(0) \\
(0) \\
(J) \\
(0) \\
(d) \\
(J) \\
(d) \\
(0) \\
(0) \\
(0) \\
(0) \\
(d) \\
(J) \\
(J) \\
(0) \\
(0) \\
(J) \\
(0) \\
(J) \\
(0) \\
(0) \\
(J)\end{array}$ & $\left.\begin{array}{l}-52.900 \\
+10.607 \\
+\quad 5.733 \\
+3.010 \\
+2.701 \\
+1.522 \\
+0.545 \\
+0.472 \\
-0.009 \\
-0.519 \\
-0.786 \\
-1.316 \\
-2.167 \\
-2.193 \\
-2.570 \\
-3.305 \\
-3.645 \\
-3.742 \\
-4.057 \\
-4.929 \\
-\quad 5.467 \\
-5.636 \\
-5.748 \\
-6.193 \\
-7.656 \\
-7.799 \\
-10.544 \\
-14.832\end{array}\right\}$ & $\begin{array}{l}\text { Hoog } \\
\text { Middel }\end{array}$ \\
\hline
\end{tabular}


SCHEMA IV. TOTAALSTRUCTUUR.

\begin{tabular}{|c|c|c|c|}
\hline JONGERE & HOOS & MIDDEN & LAAG \\
\hline HOOG & $\begin{array}{l}\text { Neuropsychia- } \\
\text { ters, huis- } \\
\text { artsen }\end{array}$ & $\begin{array}{l}\text { Kinderartsen } \\
\text { fysiotherapeu- } \\
\text { ten, radio-ra- } \\
\text { diumt herapeu- } \\
\text { ten, reunato- } \\
\text { logen, anes- } \\
\text { thesisten }\end{array}$ & \\
\hline MIDDEL & Gynaecologen & Mondartsen & $\begin{array}{l}\text { Internisten, } \\
\text { gastro-ente- } \\
\text { rologen, } \\
\text { rötgenspe- } \\
\text { cialisten, } \\
\text { klinische } \\
\text { biologen }\end{array}$ \\
\hline$\angle A A G$ & $\begin{array}{l}\text { Chirurgen, } \\
\text { orthopedisten }\end{array}$ & $\begin{array}{l}\text { Dermato-ve- } \\
\text { nerologen, } \\
\text { urologen }\end{array}$ & $\begin{array}{l}\text { Cardiologen, } \\
\text { Longartsen, } \\
\text { keel-, neus- } \\
\text { oorspecia- } \\
\text { listen, oog- } \\
\text { artsen }\end{array}$ \\
\hline
\end{tabular}

Uit Schema IV kan het volgende worden afgelezen: op de diagonal van boven links naar onder rechts tekenen zich twee fundamentele stromingen in de medische wereld af. De ene pool wordt bezet door huisartsen en neuropsychiaters. Deze artsen zijn individualisten en zien de geneeskunde als een interdependent systeem van drie krachtvelden (somatisch, psychisch en sociaal). In dit denkmodel blijkt hun grotere wardering van de paramedische hulpkrachten ten volle in te passen.

Deze integrale visie op de patiënt betekent dat genoemde artsen een conceptie hebben van de zieke als een gehele persoon die moet geholpen worden. 
Dergelijke conceptie kan best gedefinieerd worden als een bijzondere houding ten overstaan van de zieke, zoals voorgehouden door de hippocratische geneeskunde. Zij kan dus niet beschouwd worden als een nieuw ingeslagen of moderne benaderingsweg, maar als een terugkeer naar een geneeskunde van de gehele mens. In confrontatie met de zieke haudt deze geneeskunde rekening met zeer heterogene invloeden. Zij berust op een stroming die in de eerste plats a andacht verleent aan de rol die de omgeving van de mens speelt op de aandoening en aldus terug aanknoopt bij de hippocratische traditie. Deze artsen zijn overtuigd dat de ziekte noet beschouwd worden als een proces dat in bepalde opzichten inherent is aan de persoon van de zieke m.a.w. aan de natuur van de persoon. Het gat daarbij ook niet om een soort specialisme dat enkel voorbehouden is aan psychiaters, maar in heel wat specialismen van betekenis kan zijn. Immers, in de ziekte of aandoening het deel van het psychisme erkennen is zo oud als de wereld en deze houding was zowel die van de officiële geneeskunstenaars als van de genezers.

Het feit dat huisartsen en neuropsychiaters zich hier samen a anbieden kan belangrijk worden geheten in het licht van enkele andere vaststellingen zowel uit eigen aanvullend onderzoek als uit een onderzoek van ZWEENS-WIERSEMA (1968) over de relatie tussen huisarts en psychiaters.

Hun gezamenlijke multidimensionele aanwezigheid op hetzelfde niveau wist op een sterke similariteit in hun visie op de medische praxis. In het licht van vermelde onderzoeken evenwel kan het problematisch heten dat zij elkaar moeilijk vinden in de praktijkvoering, maar precies op grond van die gelijkenissen ligt de verklaring van die afstandshouding. zij werken in hetzelfde actieveld, mar het feit dat beider grensgebieden moeilijk af te bakenen zijn, werkt ongewenste doorkruisingen in de hand. Een herdefiniëring van de huisartsenpraxis, niet enkel als permanent oriënterende arts, maar 
wellicht vooral als spectalist in synthetische benaderingsmethoden van de patiënt, zou a an die integrale vleugel in de medische praktijkvoering ten goede kunnen komen.

Aan de andere pool treffen we de cardiologen, longartsen, keel-, neus- en oorspecialisten en oogartsen aan.

Zij vertegenwoordigen de andere stroming in de medische praktijkvoering met name die van de continu groejende medische technocratie.

Deze specialisten, met een geavanceerd wetenschappelijke cultuur, zijn door hun vorming zelf meer geinteresseerd in de ziekte dan in de eigen persoonlijkheid van de zieke. Zij zijn occasionele therapeuten met een conceptie van de zieke als een individu met een ziekte die moet genezen worden. De hoge graad van specialisatie vereist een complex instrumentarium. Uit hoofde van de financieel-economische uitbouw van de technisch-natuurwetenschappelijke geneeskunde zijn deze specialisten vaak verplicht over te gaan tot team-gerichte praxis in ziekenhuisverband. Vaak komen zij terecht in modelklinieken die met gespecialiseerde équipes, uitgerust met geperfectioneerde instrumenten en ultra-moderne laboratoria, de spil geworden zijn van de organisatie van de gezondheidszorg, wartegen de geisoleerde specialist niet opgewassen is.

Langs steeds meer, méticuleus uitgevoerde laboratoriumonderzoeken en nauwkeurig uitgevoerde technische ingrepen en behandelingen, wordt gestreefd nar tastbare resultaten en successen.

Om hogervermelde redenen kan dit wetenschappelijk ideaal enkel worden bereikt binnen het kader van een onafwendbaar door de samenleving gedragen, steeds duurder wordende geneeskunde.

De groeiende complexiteit van de medische problemen, het groeiend a anbod van de specialistische gezondheidszorg, zoals hierboven geschetst, doet ook de vragg naar deze geneeskunde onophoudelijk stijgen.

Tot op dit punt werden slechts twee aspecten van schema IV behandeld. 
Allereerst werd gewezen op de diagonal die het totaalbeeld van de samengenomen dimensies doorkruist. Deze wijst $O P$ een continuum dat in de gehele geschiedenis van de geneeskunde te onderkennen valt. Twee polaire type-artsen tekenen zich als twee ideal-typen af. Enerzijds is er de individueel werkende, op de zieke en niet op de ziekte gerichte arts, anderzijds onderkennen we de vooral in team-verband werkende, op de ziekte en niet op de zieke als persoon gerichte arts. De in deze twee type-artsen vertegenwoordigde visies op geneeskunde en geneeskunst zijn beide noodzakelijk voor een evenwichtige gezondheidszorg. Anders gezegd, zowel de behandeling van de integrale persoon als de technische perfectie van de noodzakelijk geachte ingreep moeten in de medische daad als zijnsgebonden elementen hun uitdrukking vinden.

In de tweede plats werd betoogd dat, scores op deze totaal-dimensie slechts bij een beperkt aantal specialismen eenduidig en goed verklaarbaar zijn.

De huisarts en de psychiater, of zij nu ouder of jonger zijn, kunnen alleen al door de aard van hun werk verwacht worden patiënt-en niet ziektegericht te werken. Van cardiologen en longartsen en ook van keel-, neus- en oorspecialisten en oogartsen, alweer of zij nu ouder of jonger zijn, kan daarentegen worden verklaard dat deze specialisten eerder ziekte- dan ziekegericht werken.

Treffend is, dat deze eenduidigheid slechts kenmerkend is voor een zeer beperkt aantal specialismen. Maar even merkwardig is, dat in alle andere disciplines oudere en jongere artsen niet enkel verschillend reageren, doch dat de situatie voor uitgesproken heelkundige specialismen duidelijk anders ligt dan voor niet heelkundige specialismen.

In schema IV is dit onderscheid gewoon af te lezen. Door hun ligging aan weerszijden van de diagonal van hoogl hoog naar lagllaag, onderscheiden zich beide categorieën opvallend van elkar.

Hoe moeten deze frappante bevindingen geduid worden ? 
In grote lijnen zou men het volgende kunnen poneren. Het sterk accent dat in de moderne geneeskunde op technische specialisatie wordt gelegd, heeft niet belet dat, warschijnlijk door de aard van hun werkzamheden, bepalde disciplines (psychiaters, huisartsen) meer vatbaar zijn voor een steeds opnieuw ontdekken van een stel vaste warden die tekenend waren voor de hippocratische geneeskunde. Zij de gemiddelde beroepsbeoefenar nu jonger of ouder, de boventoon in zijn praktijkvoering is op de zieke gericht.

De cardiologen, longartsen, keel-, neus-, oorspecialisten en oogartsen vormen de tegenpool.

De wijze warop zich deze artsen uitdrukken kan duiden op een grotere vatbaarheid voor technische innovaties. Als boventoon en vast omlijnde regel geldt, aandacht voor de ziekte.

Bij alle andere disciplines is mogelijk de aard van de werkzamheden niet zo eenduidig. Dit kan wijzen op veranderbadrheid van opvattingen over de praktijkvoering in deze specialismen. Moeilijk te voorspellen echter blijft, welke richting in welke disciplines deze opvattingen zullen inslaan. In elk geval kunnen in het groeiproces overvloeingen ontstaan hetzij van meer ziekegericht naar meer ziektegerichte opvattingen of omgekeerd.

Keren we terug tot Schema IV. Boven de diagonal bevinden zich een a antal specialismen warvan de jongere beoefenaren meer ziekegericht scoren dan de ouderen. Het zijn de jongere kinderartsen, fysiotherapeuten, radio-radiumtherapeuten, reumatologen, internisten, gastra-enterologen en een aantal jongere ondersteunende specialismen (anesthesisten, röntgenspecialisten en klinische biologen).

Een plausibele overweging bij deze bevinding is, dat zij een weerspiegeling van een generatieversohil kan zijn op een par uitzonderingen na, kennen alle deze specialismen de laatste decennia een sterke groei in de vorm van de procentuele stijging van het aantal beoefenaren. 
Immers, in hun gespecialiseerde opleiding hebben zij kennis gemakt met een sterk uitgebouwde paramedische infrastructuur, die hen als een onontbeerlijke entourage voor een totale benadering van de patient ten dienste stond. De ouderen kenden dit niet. Mogelijk is de jongere fractie dan ook weer op weg naar een meer integrale zhekegerichte benadering.

Deze enkele meting van het verschijnsel laat evenwel een zekere twijfel bestaan omtrent de algemeenheid van voorgaande overweging. Mogelijk ligt immers ook een plausibele verklaring voor de leeftijdsverschillen in het levensfaseverachit De jongere kinderarts, fysiotherapeut of internist start, andanks een breed veld van niet onmiddellijk definjeerbare aandoeningen, vaak idealistisch patiëntgericht in zijn vak, doch ouder geworden, magelijks ook ontmoedigd, maakt hij een krisis door die hem tot een meer ziektegerichte benadering leidt.

Beneden de diagonal bevinden zich de resterende, mar dan heelkundige specialismen war thans de ouderen meer ziekegericht scoren dan de jongeren. Het zijn de gynaecologen, chirurgen, orthopedisten, dermato-venerologen en urologen.

ook met deze specialismen kan voorgaande verklaring compatibel zijn.

Als het gaat om een generatieverschil, zou dat betekenen dat de aankomende generatie heelkundigen sterk medischtechnisch en ingreepgericht werkt. Als "super-techniekers" is het hen wellicht een allergewoonste zaak een stel verantwoordelijkheden te nemen in situaties war de menselijke kwetsbaarheid veel groter is dan bij de niet-snijdende specialismen. Aldus wordt bij deze jongere artsen de boventoon gevoerd door hun technsche kennis en vaardigheden.

Voor de oudere generatie die destijds niet dat snelle tempo van moderne medisch-technische wituindingen hebben beleefd, blijft de patient meer in zijn totaliteit spreken.

Nochtans kan ook hier weer de hypothese omtrent levensfaseverschillen worden geformuleerd. 
Vooral in de heelkundige specialismen domineert de techniek. De jongere beoefenaren treden enthousiast aan, vol vertrouwen in hun kennis en hun "automatisch" genezend mes. zij zijn gericht op het ziektebeeld, warin een systematische houding wordt aangenomen. Duder geworden blikt de heelkundige terug. Op grond van zijn levens- en vooral van zijn praktijkervaring heeft hij geleerd, de patient niet langer meer als een louter organisme te zien. Inzicht in de betrekkelijkheid van zijn techniek brengt hem dichter bij de patient als individu.

Dit dualisme in de interpretatie van de eindresultaten van dit onderzoek moet dan ook een uitnodiging zijn om door voortgezet en meer toegepast orderzoek de grondhouding van de verschillende specialisten ten opzichte van hun werk nader te bestuderer en tevens door voortgezette meting na te gaan of ce leeftijdsverschillen hun sorzaak vinder in generatieverschillen of in levensfaseverschillen of in beide.

5.3. Beknopt overzicht van de poging tot profilering.

In dit hoofdstuk wordt aanvankelijk gepougd de onderscheiden afhankelijke variabelen onder controle te houden door ze achtereenvolgens te toetsen naar hun afhankelijkheid van een aantal onafhankelijke variabelen. De werkwijze hierbij verlooot iteratief d.w.z. dat trapsgew jze wordt nagegaan welke onaf hankelijke variabele van de eerste orde is en vervolgens we ke onafhankelijke variabele van de tweeda, van de derde orde is enz... die de betrokken afhankelijke variabele verklaren. Deze analyse zoekt alsdan naar zuivere samentangen die niet gecontamineerd worden door de voorgaande variabele. Aldus wordt inzicht verkregen in de bijdrage van afzonderlijke variabelen tot de verklaring van de variantie in de pestudeerde afhankelijke variabelen.

Opinies en wardeoordelen treden echter zelden geĭsoleerd op, zodat zich een meer zinvolle benadering opcringt. Het is immers belangrijk te weten in welke zin kenobjecten (in casu de artsen) door meerdere kenmerken van elkaar ver- 
schillen. Daartoe wordt beroep gedaan op een multidimensioneLe schaltechniek die toelaat deze kenobjecten in een a antal dimensies te plaatsen wardoor zij dan ook bepaald worden. Daar deze technieken, zoals eerder reeds vermeld, enkel op dichotomieën kunnen worden toegepast, beperken zich de gevonden significante relaties tot de concentratie in én der twee subcategorieén. Zodoende is bij interpretatie ervan toch enige gereserveerdheid geboden.

Dergelijke werkwijze krijgt evenwel bij extensief onderzoek een bijzondere plaats. Immers extensief onderzoek beoogt een zo breed mogelijke structuur te verkennen en ze functioneel of causaal te beschrijven.

Uit de resultaten die in deze synthese nar voren zijn getreden blijkt dujdelijk hun aansluiting bij de meer fractionele vaststellingen in de voorgaande hoofdstukken. Het is dus mogelijk gebleken tussen de vele elementen bij dit onderzaek betrokken verbindingstijnen te trekken onder de vorm van dimensies.

De leeftijd van de arts en het specialisme dat hij uitoefent blijken de voornaamste factoren te zijn die de verschillen in de praktijkvisie bepalen.

Door de aard van hun werkzamheden treden huisartsen en neuropsychiaters, ongeacht hun leeftijd, naar voren als ziekegerichte artsen. Als tegenpool hebben zij een aantal specialisten die medisch-technisch, dus ziektegericht zijn. ongeacht hun leeftijd horen hierbij: de cardiologen, longartsen, keel-, neus- en oorspecialisten en de oogartsen.

Treftend anders is de positie die duidelijk heelkundige spectalismen innemen. Hier blijkt het levensfaseverschil het verschil in praktijkvisie te bepalen. Dit komt overduidelijk tot uiting bij de chirurgen en de orthopedisten. Jongere beoefenaren van deze disciplines, warschijnlijk uit hoofde van een sterke accentuering in de moderne geneeskunde van technischevervolmaking, zijn uitgesproken meer ziektegericht dan de ouderen onder hen. Dit geldt ook, doch in minder sterke mate voor de gynaecologen. 
Bij een derde categorie van specialisten war de praktijkvisie eveneens verschilt naargelang de leeftijd kan het generatieverschil bepalen dat de jongeren onder hen meer ziekegericht zijn dan de ouderen. Het betreft de kinderartsen, fysiotherapeuten, radio-radiumtherapeuten, reumatologen en anesthesisten.

Voor de restgroep van internisten, gastro-enterologen, röntgenspecialisten en klinische biologen valt het moeilijker een verklaring te verstrekken. Het verschil in visie tussen jongeren en ouderen loopt niet sterk uiteen, zodat kan geopperd worden dat, a fhankelijk van individu tot individu, nu eens een meer zieke-, dan weer een meer ziektegerichte instelling primeert.

Aan een par punten in verband met het basis-onderzoek mag echter niet kritiekloos worden voorbijgegaan.

Kreeg de studie bij het artsenkorps een vrij behoorlijke responsie, dan zijn de onderzoekgegevens niat van zeer recente datum. Het veldonderzoek werd immers beëindigd in 1968 . Aan het te lang uitblijven van de uiteindelijke rapportering ligt, nast een a antal andere omstandigheden, ondermeer ook het feit ten grondslag dat onze statistische zienswijze van waruit werd vertrokken, op een te enge basis berustte.

fr werd dan ook tot een grondige herstructurering van de onderzoekgegevens overgegaan, wat in niet onaanzienlijke mate bijkomend opzoekings- en studiewerk heeft gevergd.

In vraag moet dan ook gesteld worden of de bevindingen die uit het voorliggend onderzoek zijn naar voren getreden, sterk zouden verschillen van meer recent onderzoek op dit gebied.

Met alle reserves die aldus bij deze studie moeten gesteld worden, kan wel gewezen worden op het feit dat de medische wetenschap en de opleiding daarin de latste jaren van verhoogde techniciteit getuigt en, strikt genomen, het terug aanknopen bij een hippocratische geneeskunde nog steeds een belangrijk vraagteken vormt. 
Indien we erin geslaagd zijn, ondanks onvermijdelijke tekortkomingen, de zelfconceptie van de artsen in de medische praxis dimensioneel te analyseren, dan zou het, mede op grond van onze bevindingen, nuttig en wenselijk zijn verder onderzoek te verrichten en dit toe te spitsen op de leeftijdsverschillen binnen de diverse disciplines.

De Leemten, die wj in deze verkennende studie aanvoelen, kunnen dan worden opgeheven door rechtstreeks op zoek te gaan naar de dieperliggende betekenis van die verschillen. Een meer verfijnd inzicht in deze kan dan ook met meer gezag aanwijzen in welke medische disciplines ofwel het levensfaseverschil, zo niet het generatieverschil of beide werkzaam zijn. 
SAMENVATTING

De studie brengt verslag uit over een onderzoek naar praktijkvoering en zelfevaluatie van 1654 belgische huisartsen en specialisten.

Aanleiding tot deze studie was de vaststelling dat, in de medisch-sociologische literatuur, ondanks de steeds voortschrijdende specialisatie in de geneeskunde, geen systematisch onderzoek te onderkennen viel over mogelijke differentiaties in de rolconceptie van de artsen hargelang hun specialistische discipline. Verondersteld werd dat dit specialisatieproces a anijsbare verschillen in de rolconceptie moet sorteren en dit onvermijdelijk invloed heeft op een al dan niet of minder integrale benadering van de zieke.

Vertrekkend van deze hypothese werd besloten een onderzoek te verrichten dat, gezien de probleemstelling, voldoende extensief moest zijn, om de vermeende verschillen in de rolconceptie te kunnen opsporen.

Het vrij omvangrijk onderzoekingsmateriaal werd verzameld bij middel van een in de nederlandse en de franse taal opgestelde vragenlijst. Rekening houdend met de geografische spreiding van de betrokkenen over beide taalgebieden, werden 5.153 exemplaren in gedrukte vorm per post verstuurd. Een ruim opgevatte toetsing van de vraagstelling bij 400 artsen ging an het definitief onderzoek vooraf.

Voor de huisartsen werd gebruik gemakt van een a-selecte steekproef in beide taalgebieden. Van de 900 angezochte huisartsen werden 330 antwoorden bekomen ( $36.6 \%$ wat van 16 als ongeldig werden geweerd. Voor de specialisten werd de totale populatie a angeschreven om te vermijden dat weinig bezette disciplines in het onderzoek zouden ontbreken. Van de 4.970 a angezochte artsen-specialisten condanks tijdrovende inspanningen kon bij gebrek aan degelijke adressenlijsten niet jedereen worden bereikt) werd een respons bekomen van 1.397 personen $(28.1 \%)$ warvan 57 antwoorden als onbruikbar moes- 
ten worden geweerd.

Dat de respons behoorlijk kan worden genoemd moge blijken uit slechts enkele kleine afwijkingen die de verhoudingscijfers met betrekking tot de onderscheiden specialismen in de totale populatie vertonen.

Het onderzoek bestaat uit twee delen. Het eerste deel handelt uitsluitend over de wije warop de artsen de randmedische context van hun praktijkvoering verzorgen. Door middel van de chi-kwadraat toets wordt gezocht naar de significante relatie van deze inzet met een antal achtergrondvariabelen.

Het eerste hoofdstuk brengt verslag uit over het verloop van het onderzoek en de voorbereiding van het onderzoekingsmateriaal. In het tweede hoofdstuk wordt nagegaan in hoeverre de artsen hun academische opleiding adequat hebben gevonden. Op welke wijze en in welke mate de ondervraagden getuigen van een reelle belangstelling in verband met de matschappelijke en psychologische aspecten van hun praktijkvoering, wordt onderzocht aan de hand van het belang dat zij hechten aan het inwinnen van randmedische informatie in de praxis, van het aanwenden en warderen van paramedische hulpkrachten, van hun appreciatie van medisch teamwerk en hun uitgebrachte voorkeur voor de individuele of voor de groepspraktijk. In het derde hoofdstuk wordt in het licht van het spectalisatieproces gepeild naar opinies en attitudes van de arts omtrent de sociaal-psychologische achtergronden en de preventie in de praktijkvoering.

In het tweede deel van deze studie wordt bij middel van de factoranalyse techniek gepoogd enkele wardehoudingen (verantwoordelijkheden) in de rolvervulting van de artsen te identificeren en te omschrijven, met name: de social-integratieve, de informatieve, de sociaal-opvoedende en de psycho-therapeutisch/"magische" rolcomponent.

Deze rolcomponenten worden in hoofdstuk IV verklaard in functie van de variabelen die in het eerste deel worden geanatyseerd. 
Hoofdstuk $V$ brengt de synthese van het onderzoek. Hierin wordt met behulp van de techniek der trapsgewijze regressie en van een multidimensionele schalanalyse een totaalbeeld van de praktijkvoering getekend. Aangezien deze onderzoekstechnieken enkel kunnen toegepast worden wanneer de ondervraagde op alle vragen heeft geantwoord, heeft de totaalbenadering betrekking op 1.414 artsen.

In deze poging tot profilering wordt vastgesteld dat de zelfconceptie van de medische praktijkvoering in alle behandelde facetten kan herleid worden tot drie dimensies : - de individualistische hulpverlening, de integrale geneeskunde, de wardering van gekwalificeerde hulpkrachten.

Hierbij duiden de resultaten er op dat over de gehele lijn van het onderzoek twee verklarende variabelen van bijzondere betekenis zijn, met name de leeftijd en het beoefend specialisme.

Een interrelationele benadering van de drie dimensies in functie van beide variabelen geanalyseerd, toont aan dat twee fundamentele stromingen, te omschrijven als twee poLen van een continuum, de medische wereld doorkruisen.

De ene pool, bezet door huisartsen en neuropsychiaters, wijst op een geneeskunde die bijzondere aandacht verleent a an de rol die de omgeving van de mens speelt op de aandoening. Het is de aard van de betrokken medische disciplines die deze instelling bepaalt. Het leeftijdsverschil is geen kenmerkende variabele.

De andere pool is kenschetsend voor een continu groeiende medische technologie, vertegenwoordigd door cardiologen, longartsen, keel-, neus- en oorspecialisten en oogartsen. Ook hier is er geen aanwijzing dat het leeftijdsverschil een rol speelt en is het de specifjeke aard van de werkzaamheden in déze specialismen die genoemde instelling bepalt.

In andere disciplines reageren oudere en jongere artsen verschillend doch, athankelijk van het specialisme, dus vermoedelijk door de aard van hun werkzamheden, mede door hetzij, het levensfaseverschil of door het generatieverschil, zal ofwel aan eenziekegerichtebenadering worden vastgehouden, ofwel een medisch technische en dan ook meer ziektegerichte 
handeling worden gesteld.

De restgroep omvat een aantal specialismen war noch de leeftijd, noch de aard van de werkzamheden de instelling van de arts duidelijk condtioneert, maar war mogelijks het verschil van individuen de verschillen in de praktijkvisie verklaart.

Enige restrictie is evenwel geboden bij de resultaten indeze studie vervat. Het veldonderzoek werd afgesloten in 1968. Aan de vertraagde rapportering ligt een samenloop van werkomstandigheden ten grondslag. Bovendien evenwel werd bij een eerste versie van een te eng statistisch werkconcept vertrokken, op grond warvan op ingrijpende wijze een nieuwe analyse heeft platsgevonden.

Indien bij genoemd negatief geluid moet berust worden, dan nopen de resultaten van deze verkennende studie, warin gepoogd werd de medische praxis differentieel naar specialistische discipline te analyseren, tot nader onderzoek dat zich in elk geval bewust dient te richten naar een meer precieze benadering van verschillen in leeftijd en generatie tussen medische beroepsbeoefenaren. 
SUMMARY

This book deals with the study of the practice and self-evaluation of 1.654 Belgian doctors and specialists.

The first motive for working out this study was the lack in medical-sociological literature of any systematic research into the possible differentiation in role canception of doctors according to their specialized disciplines, in spite of the continual specialization in the medical profession. It was assumed that the process of specialization would lead to demonstrable differences in role conception and that this would inevitably influence the degree of integral approach of the patient.

This assumption was the starting point of the study. In view of the problem put forward, the research had to be sufficiently extensive in order to detect the presupposed differences in role conception.

The rather extensive research material was compiled by means of a questionnaire in Dutch and French. Printed questionnaires were sent to 5.135 persons in both language areas. An extensive prequestioning of 400 doctors preceded the definitive enquiry.

As far as family doctors were concerned, a random sampling procedure was performed. 0ut of the 900 general practitioners invited to answer, 330 replied $(36,6 \%)$; I 6 replies were excluded as being invalid. As far as specialists were concerned, data were gathered from the total population so as to avoid lessoccupied disciplines from being excluded.

In spite of time-consuming efforts, the total population could not he reached due to the lack of complete lists of adresses. Eventually, we wrote to 4.970 specialized doctors. 1.397 of them answered $(28 ; 1 \%) ; 57$ replies were excluded as they were considered of no use. 
This is a fair resporise as it shows only a few small deviations from the proportions represented by the different specialities in the total population.

The study consists of two parts.

Part one deals exclusively with the way in which doctors pay attention to the surrounding medical context of their practice. By means of the chi-square test we tried to ascertain the significani relation of this approach with a number of background variables.

Chapter one deals with the design of the research and the preparation of the research material. Chapter two examines to what extent the doctors have found their academic training adequate. In addition, this chapter goes into the problem nf how and to what extent the interviewed doctors evidence a real interest in the social and psychological aspects of their practice. This is studied on the basis of the importance they set upon gathering supplementary medical information, the use and appreciation of para-medical help, the appreciation of medical teamwork and their preference as to individual or group practice. The third chapter probes into the opinions and attitudes of the doctors with respect to the role of social-psychological backgrounds and of prevention in their practice. This is examined in the framework of continuing specialization.

The second part of this study tries to identify and define some value attitudes (responsibilities) in the role fulfilment of the doctor, particularly the social-integrative, the informative, the social-educational and the psycho-therapeuticl 'magic' role component. This is done by means of the factor analysis technique.

In chapter iv these role components are explained on the basis of the variables analyzed in part one.

chapter $V$ is the synthesis of the examination. Here we characterize the global image of the doctor's practice by means of the stepwise regression technique on the one hand and by means 
of a multidimensional scale analysis on the other hand. Since these research techniques are applicable only when the individual has answered all the questions, this global approach refers to 1.414 doctors.

This attempt at profile-sketching shows that a doctor's self-conception of his practice in all of the treated facets can be reduced to three dimensions : the individualistic medical treatment, the integral medical practice, the appreciation of qualified para-medical staff. The results in relation to these dimensions point to the special significance of two variables i.e. age and specialized discipline.

When analyzing an interrelational approach of the three dimensions on the basis of these two variables, it is revealed that two fundamental trends, to be defined as the two extremes of a continuum, seem to be crossing the medical world. One extreme, occupied by family doctors and neuro-psychiatrists, points to a kind of medecine that pays special attention to the influence of man's environment on the nature of his complaints. This attitude on the side of the doctor is determined by the nature of the medical discipline he belongs ta. Age is not a discriminating variable on this side of the continuum.

The other extreme side is characteristic of the continually growing medical technology, as represented by cardiologists, lung specialists, throat-, nose and ear specialists and ophtalmologists. One again there is no clear indication that age plays a role and once more it is the specjfic nature of the practice in these specialities that accounts for the recorded attitude.

In other disciplines older and younger doctors do follow a different approach. Some doctors will stick to a patientoriented approach, while some others will be more symptom-minded and will treat their patients in a technical way. This difference in approach still varies with their speciality, so presumably with the nature of their activities, as well as with the phase 
in their life-cycle they are passing through and with the difference in generation.

The remaining group includes a number of specialities where neither the age nor the nature of the activities determine the doctor's approach to any significant extent. Here differences between individuals may account for the differing attitudes towards medical practice.

Some restrictions with repect to the results mentioned in this study should be kept in mind. The field work was finished in 1968. Reporting was delayed by a conjunction of working circumstances. Moreover, the first statistical working concept was not comprehensive enough; for that reason a completely new analysis was rarried through.

In spite of this negative aspect, the results of this exploratory study, in which an at tempt was made to analyze medical practice on the basis of membership of different specialized disciplines, point to the need for more thorough research. More precisely, future research should concentrate on a more accurate analysis of the role played by differences in life-cycle phase and generation among members of the medical profession. 
NOTEN

(1) Klinische biologie: in Nederland vermoedelijk uitgesplitst in klinische chemie, bacteriologie en pathologie.

Fysiotherapie: in Nederland gerubriceerd onder revalidatie en fysische therapie.

(2) Om zich als specialist te kunnen vestigen moet de betrokken arts beat, woorden aan de criteria voorzien bij de wet van 24-5-58. Deze bepalt per specialisme de voorwaarden war moet a an voldaan worden. In de regel komen deze neer op: houder zijn van een dioloma van doctor in de geneeskunde en bovendien een getuigschrift kunnen voorleggen van specialisatie in het vak warvoor geopteerd wordt. Deze specialisatie moet blijken uit een certificat afgeleverd door een belgische faculteit van Geneeskunde of gelijkwaardig erkend door één van deze faculteiten of door een interfacultaire keurrad. Een per specialisme ingestelde officiële erkennigscommissie beslist over de erkenning. Wil een reeds gevestigde huisarts of specialist tot het uitoefenen van een (ander) spectalisme overgaan, dan is hij gehouden tot het doorlopen van een stage in een door de erkenninscomissie erkende medische instelling warbij de opterende arts afziet van zijn voorheen witgeoefende huisartsenpraxis of vroeger specialisme. In afwijking van de tot éen specialisme gehouden praxis, kan de erkenningsbewilliging de witoefening van het specialisme in cumulatie met de algemene geneeskunde of met een ander specialisme toelaten, hetzij in plaatselijk verband of in streken die verafgelegen zijn van grote centra, hetzij voor een beperkte termijn.

Bij uitzondering mag de cumulatie met een ander specialisme worden toegestaan indien deze er nauw mee in verband stat of zo de omstandigheden van geografische aard dit verrechtvaardigen.

(3) Een consensus over dit facet van de professionalisering is er niet. 
(4) Dit sluit in dit opzicht geenszins de idee van het complementair karakter der diverse sociale statussen uit.

(5) De lijsten van de Rijksdienst voor ziekte en Invaliditeit waren nooit volledig en pas in 1973 kwam een globale lijst tot stand. Zij omvat : een alfabetische namlijst per provincie en per arrondissement (zonder totalisering). Per medisch specialisme zijn er dus geen cijfers bekend. Handdepouilltement is geboden.

(6) Dit geldt zowel de keuze van de medische studie als de motiveringen van hun keuze voor de algemene praxis of voor een specialisme. De resultaten van de vragstelling hierover worden niet opgenomen in de studie.

(7) Nog 230 artsen antwoordden wel positief, maar formuleerden niettemin ongevraagd ook kritieken. Samen komt dit neer op meer dan de helft der respondenten.

(8) De items warover werd geinformeerd $z i j n$ : het inkomen, het onderwijsniveau, het beroep, aspiraties, gezinsmoeilijkheden, morele problemen, betrekkingen met vrienden, financiële moeilijkheden, woonvoorwarden, vrije tijd, dieet, vroegere behandelingen. Er weze hier a an toegevoegd dat, wanneer de arts aan een aantal items een routinekarakter hecht, hij voor de overige items complementair oordeelt dat deze enkel in specifieke gevallen gelden.

(9) Hierbij zijn ook de artsen meegeteld die beide praxisvormen beoefenen.

(10) Zie voor theoretische situering en kritische beschouwingen rond deze problematiek het onderzoek van H.Philipsen over: "De omvang en complexiteit van algemene ziekenhuizen" In "De gewone ervaring leert al anders" Afscheidsbundel ter nagedachtenis a an Prof.A.N.J. den Hollander, Alphen aan den Rijn, 1976, blz.152-171.

(11) Zie nochtans de studie van I.J.A. Bernt : "Groepspraktijken en Gezondheidscentra", Rotterdam, 1973, warin de auteur een vijftigtal groepspraktijken in Nederland onderzocht naar hun medische, organisatorische, financiële e.a. 
aspecten. Zie ook vooral in verband met mogelijke en reéle conflictsituaties de belangrijke studie van Lamberts, $H_{\text {. : }}$ "Samenwerken in een team - Een routebeschrijuing door een ruig landschap". In : "Huisarts en wetenschap", no.17, $1974, b l z .15-23$.

(12) Het begrip "groepsgeneeskunde" werd ten behoeve van de artsen als volgt gedefinieerd: "uitgeoefend door twee of meer artsen, die de verbintenis hebben aangegaan rechtmatig tussen te komen in de kosten verbonden a an het medisch equipement, alsook in de zorgen verleend aan de gemeenschappelijkepatiënten. De globale inkomsten worden bovendien, ingevolge een gemeenschappelijk akkoord, rechtmatig verdeeld"*.

(13) De resultaten van deze "keuzen" werden niet opgenomen in de studie.

(14) De verwachtingen gesteld in de Inleiding bij dit hoofdstuk worden dus slechts door een goede helft ingelost.

(15) Zie wat A.Querido hiervan zegt in "Voordrachten over sociale Geneeskunde", VII +204p.. 1958, blz. 144 en vlg.

(16) Het gezondheidsbegrip ligt immers anders bij neuropsychiaters. Zie hierover Redlich,F.C. : "Der Gesundheitsbegriff in der Psychiatrie". In: "Der Kranke in der modernen Gesellschaft". (A.Mitscherlich e.a. Herausgeber, 1973 , $b(z .88-110$.

(17) Zie in verband met de veranderende rolverwachtingen en de daaraan verbonden veranderingen in de praktijkvoering: Bergsma, I. : "Gezande communicatie. Interdisciplinaire en andere communicatie in de gezondheidszorg", 1971, blz. 32; Persoon,J.M.G.: "Veranderingen in de patiënt-huisartsreLatie", 1972; Larsen, D.E. en Rootman, I. : "Physicians role performance and patient satisfaction". In : "Social szience and Medicine", Vol.10, no.1, Jan. 1976, blz. 29-32. zie ook Lammers, C.J.: "De huisarts en zijn patiënt. Een sociologische voorstudie". Soc. Wet.Verkenningen. I sonevo, blz. $110-139$. 
(18) Menzel, H., Coleman, J. en Katz,E.: "Dimensions of being "modern" in Medical Practice". In : "Journal of Chronic Diseases", Vol.9, $n^{\circ} .1$, Jan. 1959, blz. 34 en Vlg.

(19) Zoals uit a anvullend onderzoek blijkt, onderhouden deze specialisten ook veelvuldiger contacten met collega's. Zie ook bub. de interessante studie van Van den Ende,W.J. en Merens-Riedstra,A.S. : "Onderlinge relaties tussen de artsen die betrokken zijn bij de behandeling van hartinfarctpatiënten", Leiden, 1972.

(20) Een duidelijke warschuwing tegen inadequate informatie van het publiek vindt men in Theil, P. :Pour le meilleur ou le pire? L'information médicale du "grand public" ". In: Eck, M. : "Le médecin face aux risques et à la responsabilite". (Textes réunis...) Paris, 1958, blz. 416 en vlg. Zie ook de kritiek door J.de Graaf en H.Philipsen (1976) geuit tegen de wanverhouding die tussen berichtgeving in de pers over geestelijke en lichamelijke gezondheidszorg bestaat.

(21) De pessimistische visie die A.Querido formuleert over dit specialisme, wordt dan toch door deze vaststelling enigszins gemilderd. (Querido,A. : "Geneeskunst in transcendentie". In: "Werken in uitvoering. Een keur wit de geschriften van Prof.Dr.A.Querido", Amsterdam, 1970, blz. 85.

(22) Weinig auteurs hebben a deze problematiek de aandacht gewijd. Enige beschouwingen daaromtrent vinden we wel bij Steinebach,Dr.: "Arztliche Aufgaben", 1956, blz=32; Lederer,H.D. : "How the Sick view their world". In: "The Journal of social Issue" Vol.8, 1952, blz. 254-255; Field,G. : "Structured strain in the Role of the soviet Physician". In: "The American Journal of Sociology", Vol.38, $0^{\circ} .5$, March 1953, blz. 496.

(23) Zie de interpretatie die De Melker a an het verwijzingspatroon van de huisarts verbindt. Melker,R.A.(De) : "ziekenhuispatiènt, huisarts, huisgezin", Nijmegen, 1973. 
De auteur stelt dat, veranderingen in het functioneren van de huisarts kunnen bijdragen tot een vermindering van het aantal verwijzingen naar specialisten. We menen evenwel dat veranderingen in de aard van de ziekteverschijnselen tot vermeerdering van het aantal verwijzingen kunnen leiden en denken hier vooral aan de onderwardering van de psychiater. A.C. Iweers-Wiersma "Huisarts en geestelijke gezondheid" (1968) en ook J.H.Swarte (1968) stellen voor Nederland, net als wij voor België vast dat, huisartsen psychiatrische tussenkomst negeren. Dit geldt trouwens volgens ons a anvullend onderzoek niet enkel de huisartsen. Dit impliceert echter structurele veranderingen in het gezondheidsbeleid of een mentaliteitsverandering van de artsen. In verband hiermee wordt voldoende duidelijke taal gesproken door de "Werkgroep Alternatieve Economie" van Leuven.

(24) Dat de zoektocht naar "qoede" psychotherapeutische benaderingen nog lang niet ten einde is en zeker van consensus geen sprake is, wordt door K. A. Soudijn (1977) belicht.

(25) Daar deze berekeningstechnieken een gezamenlijke input van afhankelijke en onafhankelijke wariabelen inhouden, worden door het optreden van "missing values" een aantal respondenten in deze analyse uitgeschakeld. Het a antal betrokken artsen valt hiermee terug op $1654-240=1414$. 


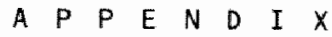

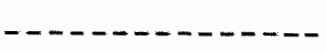


APPENDIX I.

STATISTISCHE VERWERKING

op de cijfergegevens werden volgende berekeningsmethoden toegepast : percentageberekening, significantietoets $\left(x^{2}\right)$, associatiematen (Goodman-Kruskal's $\gamma$ en somer's $d$ ), stapsgewijze meervoudige regressie, multidimensionele schaalanalyse (MINISSA-I (N) programma van EdW.E.ROSKAM).

10 De $-x^{2}-$ to 0 et $\underline{s}$.

Wanneer voor een onderzocht verschijnsel bij confrontatie met een of andere onathankelijke variabele verschilLen worden vastgesteld, moet worden nagegaan of deze niet aan het toeval te wijten zijn. Dit wordt onderzocht aan de hand van een $x^{2}-$ toets.

Deze toets gat uit van de veronderstelling (de nulhypothese) dat de vastgestelde verschillen inderdaad louter toevallig zijn. In die hypothese wordt onderzocht welke de kans is, dat in de gevonden verschillen nog meer van elkar afwijkende cijfers zouden optreden. Is deze kans kleiner dar $5 \%$, dan wordt de veronderstelling van taevalligheid verworpen en de verschillen als significant beschouwd.

Daar de $x^{2}$-verdeling een continue verdeling is, is voor de $2 \times 2$ tabellen een discontinuiteitscorrectie (correctie van Yates) toegepast.

Als associatiematen zijn verder berekend:

Goodman's Y en Somer's d.

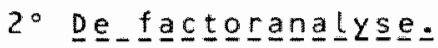

Als multivariate statistische techniek richt de factoranalyse zich specifiek tot de studie van interrelaties binnen een gegeven set wan warnemingen, warbinnen verbanden niet a-priori te onderkennen zijn. De factoranalyse vereenvoudigt een grote datamatrix tot een veel kleinere, waarbij zorg gedragen wordt dat zo weinig mogelijk informatie verloren gaat. 
Dit geschiedt langs mathematische identificatie van bindingspatronen tussen gerelateerde variabelen.

Gestart wordt met het berekenen van de intercorrelaties tussen alle variabelen. Aan de hand van deze correlatiematrix worden tussen de variabelen lineaire combinaties gemakt. Ten einde de dimensies te bepalen, wordt een "principal component-analyse" gebruikt, warbij verondersteld wordt dat de totale variantie van de variabelen kan worden verklaard. De aldus verkregen onderliggende dimensies worden factoren genoemd. zij vertegenwoordigen de originele variabelen in hun onderlinge samenhang.

Daar de verkregen factoren in de regel niet steeds een duidelijke structuur hebben d.w.z. het ideale patroon zelden of nooit bereikbaar is en derhalve niet rechtstreeks interpreteerbaar, moeten ze geroteerd worden. Een varimaxrotatie splitst daarom de varianties tussen variabelen zo op, dat een variabele hoog laadt op de ene dimensie en lag op alle andere factoren. Zodoende wordt een bevredigend resultat bekomen en blijft enkel nog de opdracht de aldus verkregen factoren in hun samenhang te benoemen.

In ons onderzoek werd de factoranalyse toegepast op een aantal statements die betrekking hebben op de visie van de artsen over het specialisatieproces, over zijn zelfidentificatie op het preventieve vlak van zijn praxis en over een aanzienlijk aantal statements specifiek betrekking hebbende op de rolvervulling. Uit deze laatste analyse kwamen vijf factoren (App.IV) tot stand die een zelfevaluatie van de arts inhouden over zijn preventieve insteling (factor I I) en dan vier rolcomponenten (factor I - III - IV - V).

De ladingen van de statements op de factoren (gerelateerd van de variabelen met de ondertigaende factoren), zijn pas dan betekenisvol geacht voor de nam van de dimensie, wanneer de moduluswarde groter is dan. 30 . 
Voor de berekening van de score van een individu op de betreffende factor is gebruik gemakt van de methode met "generalized inverse" van de factormatrix. De uiteindelijke scores zijn genormaliseerd en gestandaardiseerd: ofwel het gemiddelde is nul en de standaardafwijking van de frequentieverdeling is gelijk aan éen. Het intervalniveau van de factoren is bij bewerking van de tabellen met variabelen van lager niveau (verklarende variabelen) in vier categorieèn ingedeeld, $n l$. :

$<-1.01 ;-1.01-\leqslant 0.00 ; 0.01-\leqslant 1.00$ en 1.01 en hoger

De factaren zijn na deze indeling gecontroleerd op

het criterium van géén samenhang tussen de dimensies. Aan deze eis werd op bevredigende wijze voldaan.

$3^{\circ}$ MI I I SSA $=I(N)-2-M \underline{L}$ t

Multidimensionele schaling van gelijkenissen tussen stimuli (in onderhavig geval warnemingen) beoogt de coördinaten te vinden van $n$ punten die de warnemingen vertegenwoordigen in een n-dimensionele ruimte en wel zodanig dat de afstanden tusser: twee punten bij benadering dezelfde rangorde hebben als die van de gelijkenissen tussen de warnemingen. oe schaling moet geschieden op basis van ordinale data m.a.w. men gebruikt alleen de rangordening van de gelijkenissen.

Methoden voor ordinale data door Kruskal en Guttmanl Lingoes ontwikkeld, vertoonden evenwel bepalde bezwaren waraan Roskam en Lingoes achteraf verhielpen door het samenstelLen van een algorithme dat de goede eigenschappen van beide voorgaande methoden verenigde in MINISSA-I (N). Dit programma eist een symmetrische matrix van gelijkenissen-indices tussen $n$ elementen (warnemingen), zonder ontbrekende gegevens. Derhalve heeft de multidimensionele schaalanalyse toegepast in onderhavig onderzoek slechts betrekking op 1414 artsen (d.w.z. de betrokken artsen hebben op alle variabelen geantwoord). 
- S.

Deze techniek selecteert uit de betrokken verklarende variabelen da optimale subgroep van de athankelijke variabele d.i. het kieinst a antal variabelen die de grootst mogelijke neervoudige correlatie geven met het beschouwde criterium. 


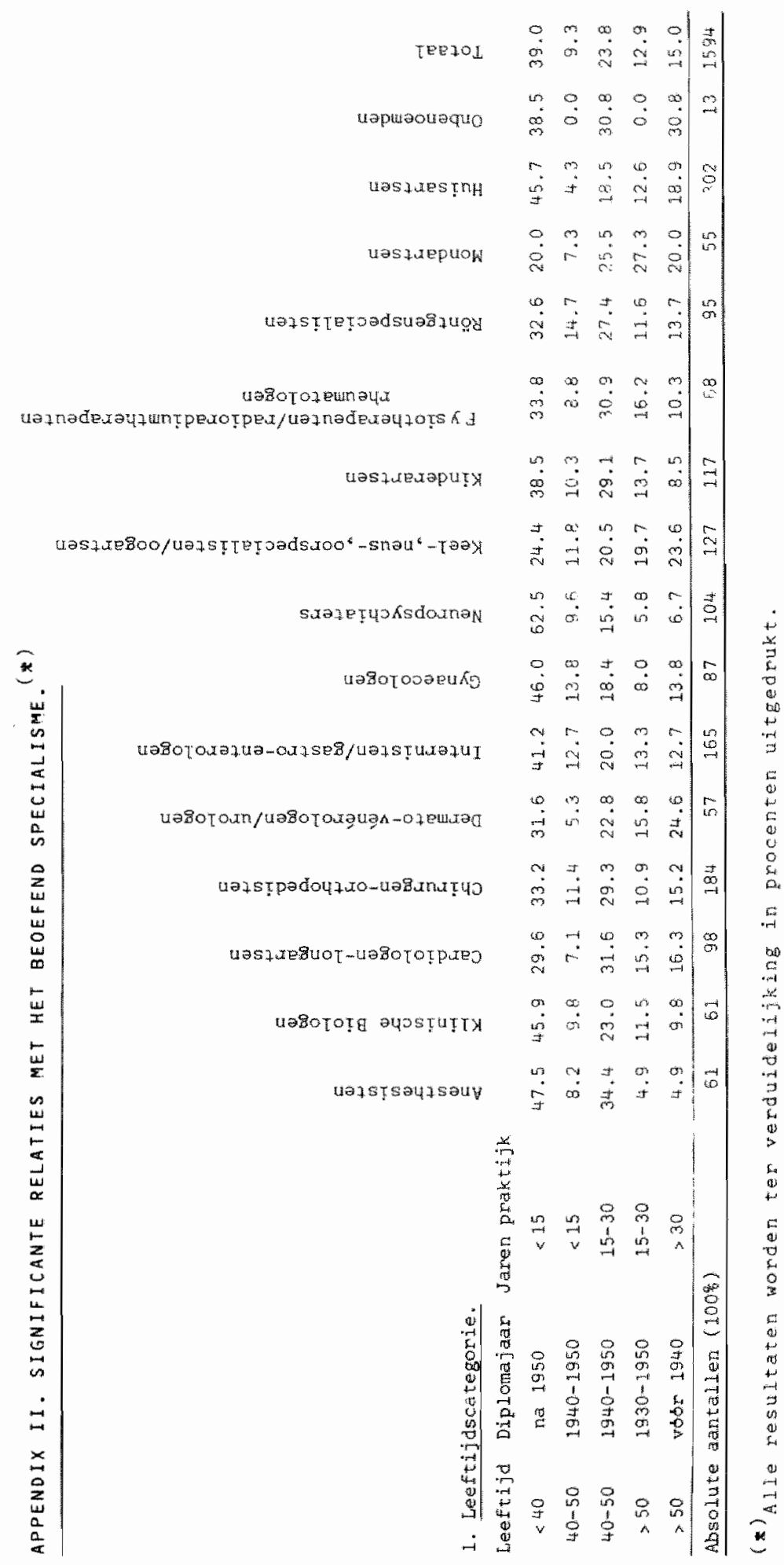




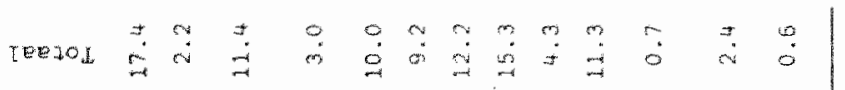

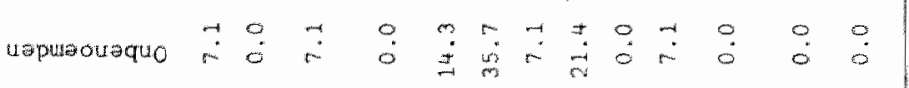

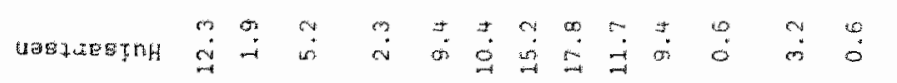

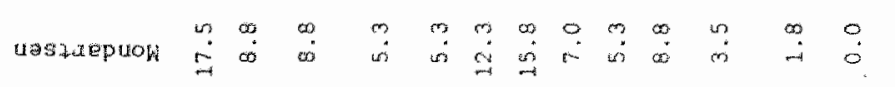

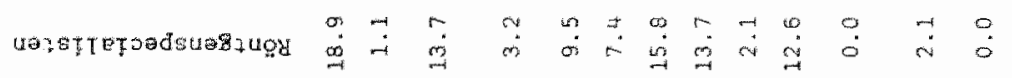

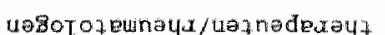
- Un pedorped/uaznadedaytoreht

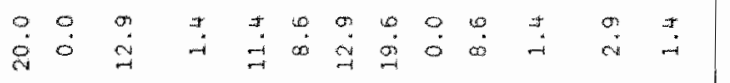

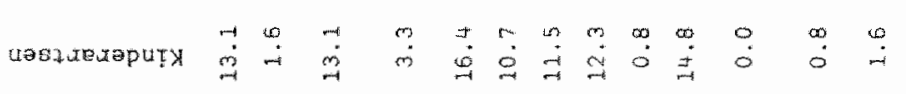

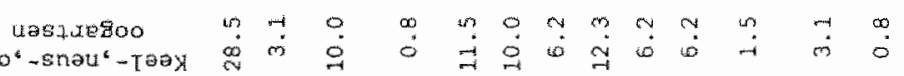

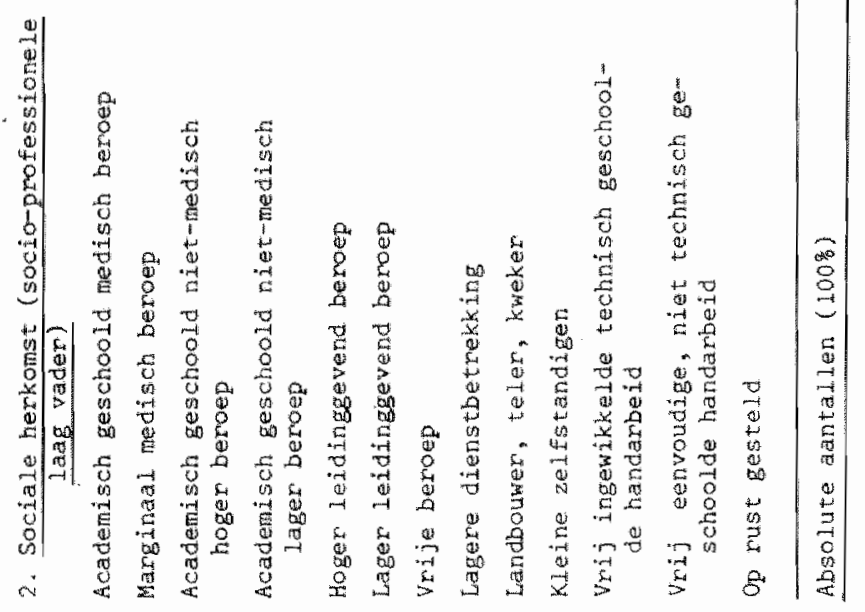




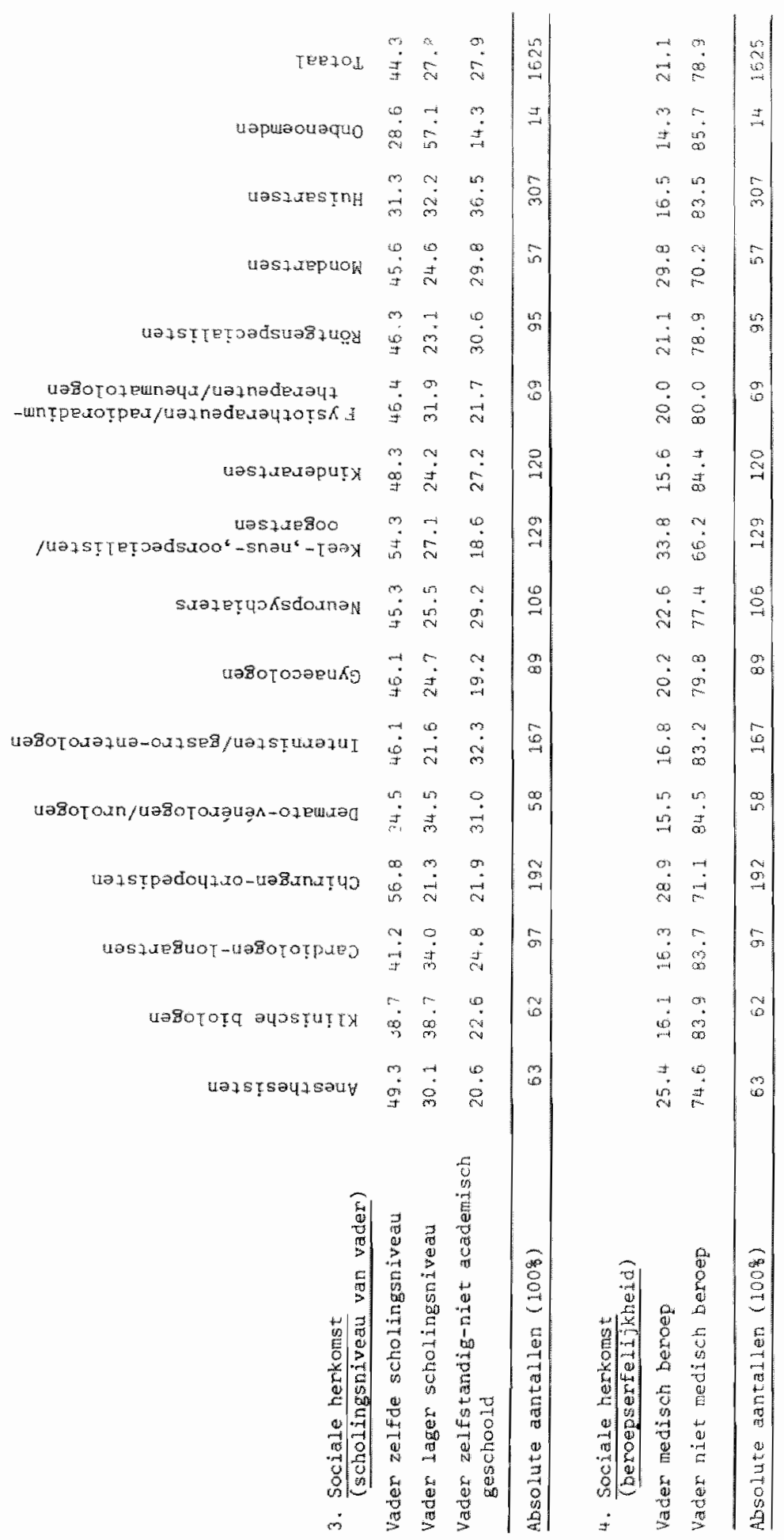




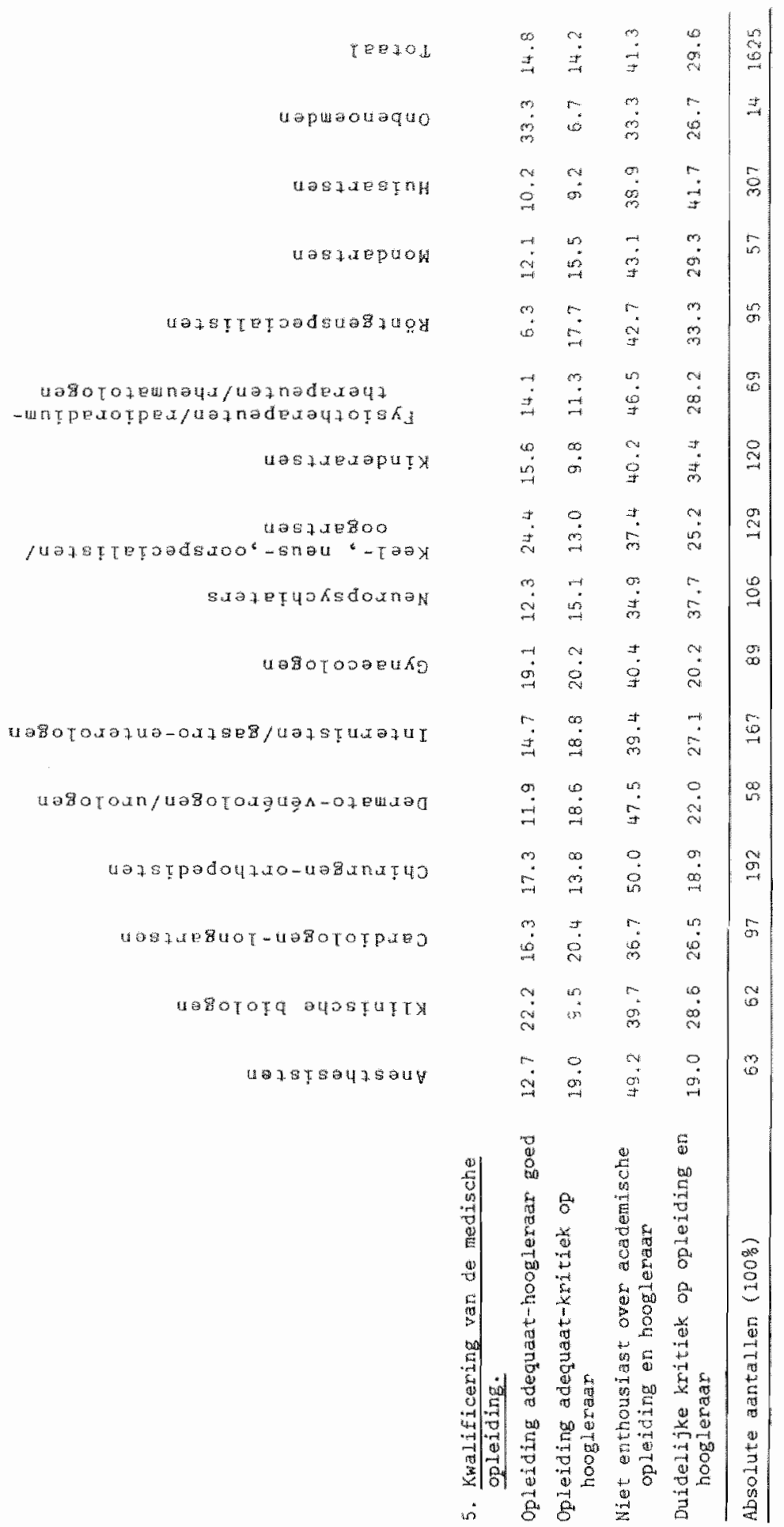




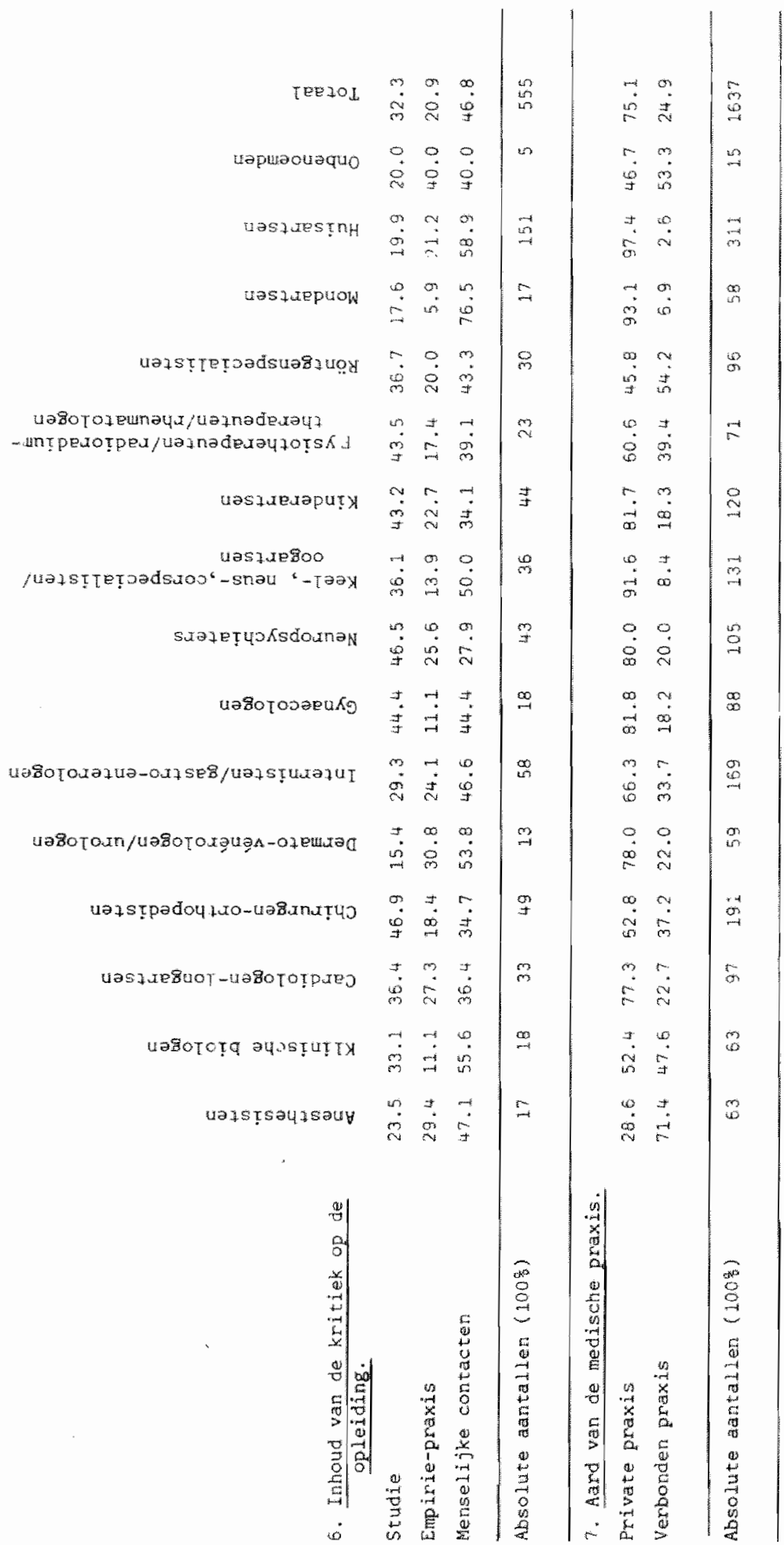




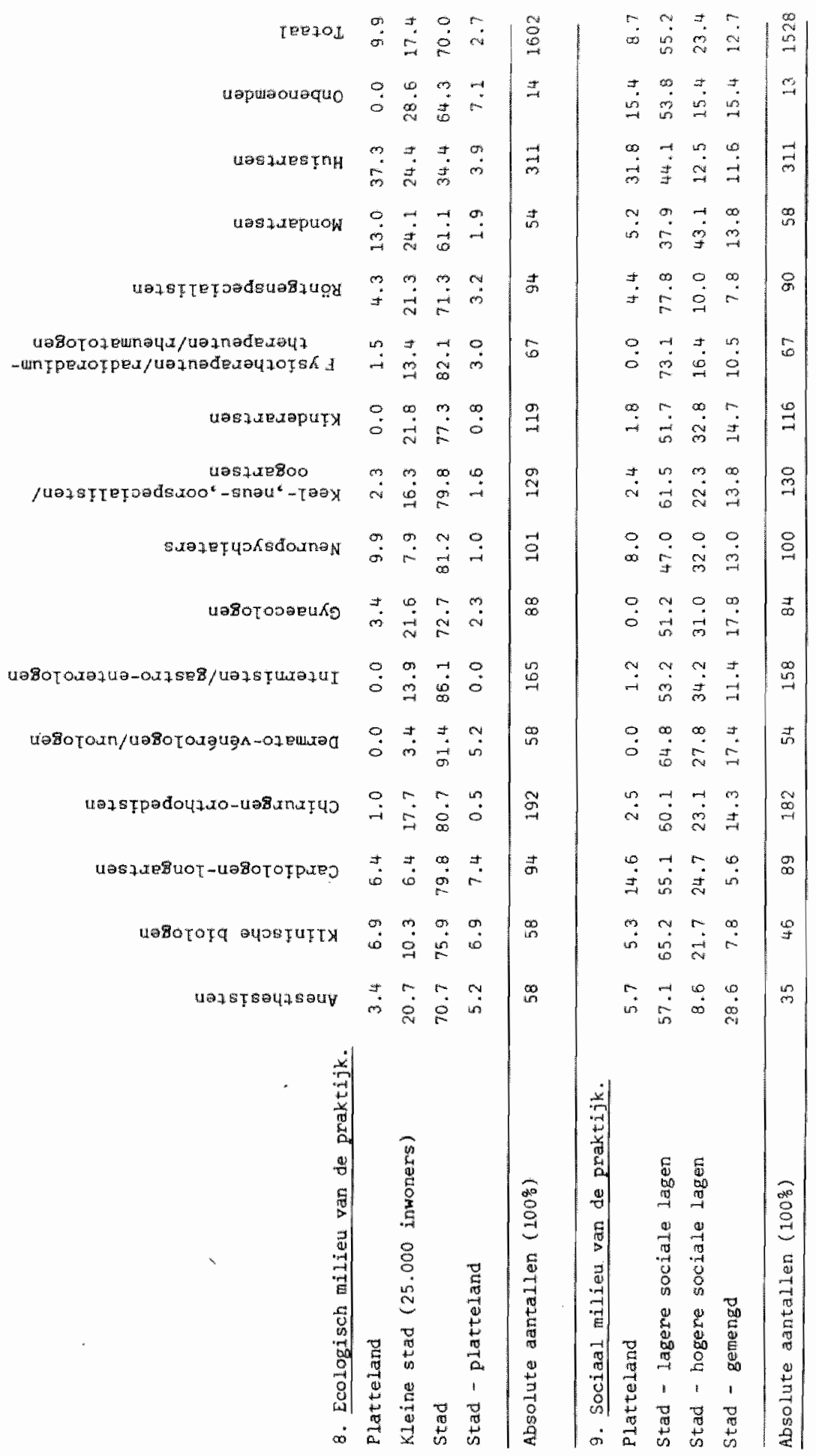




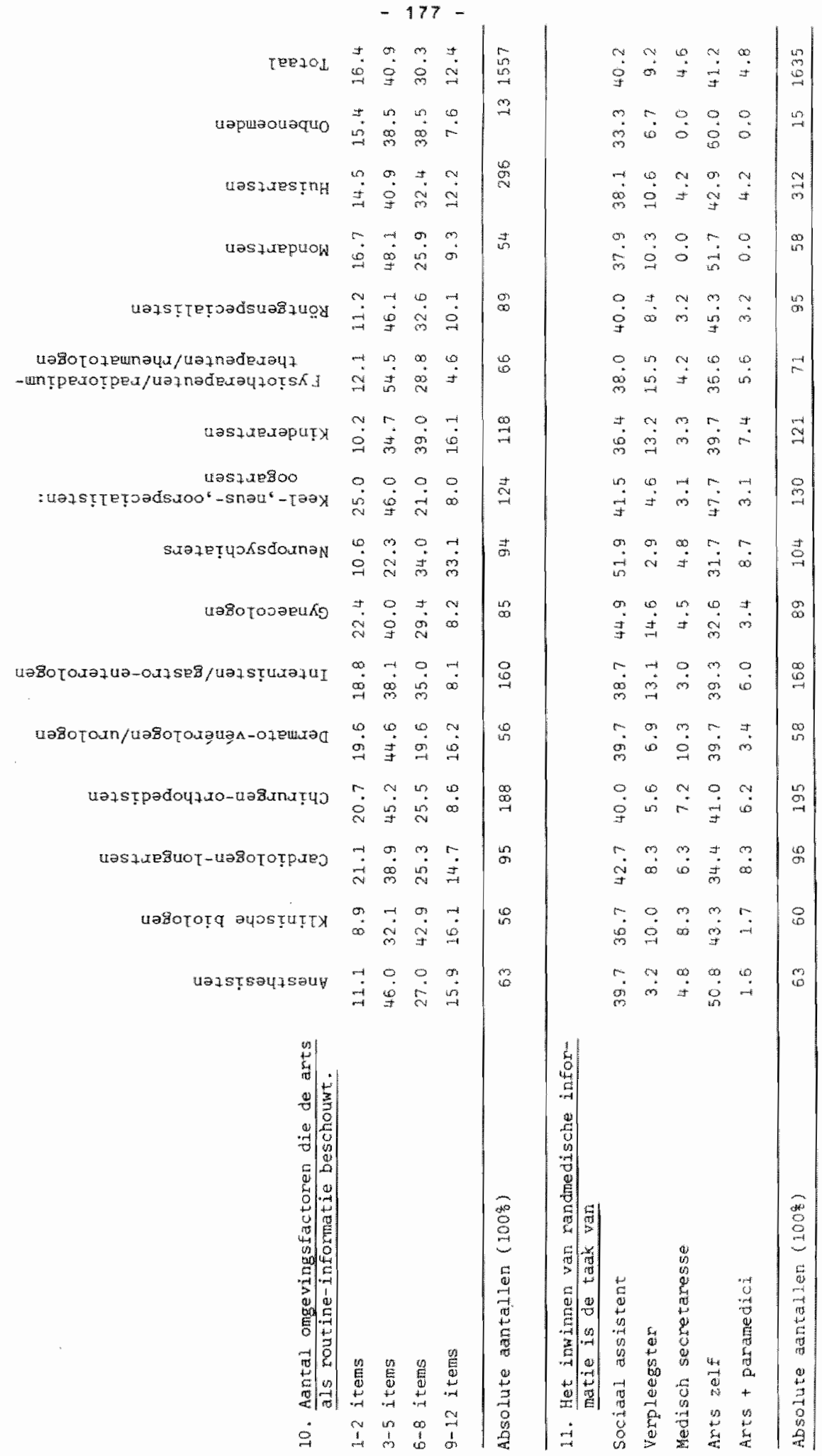




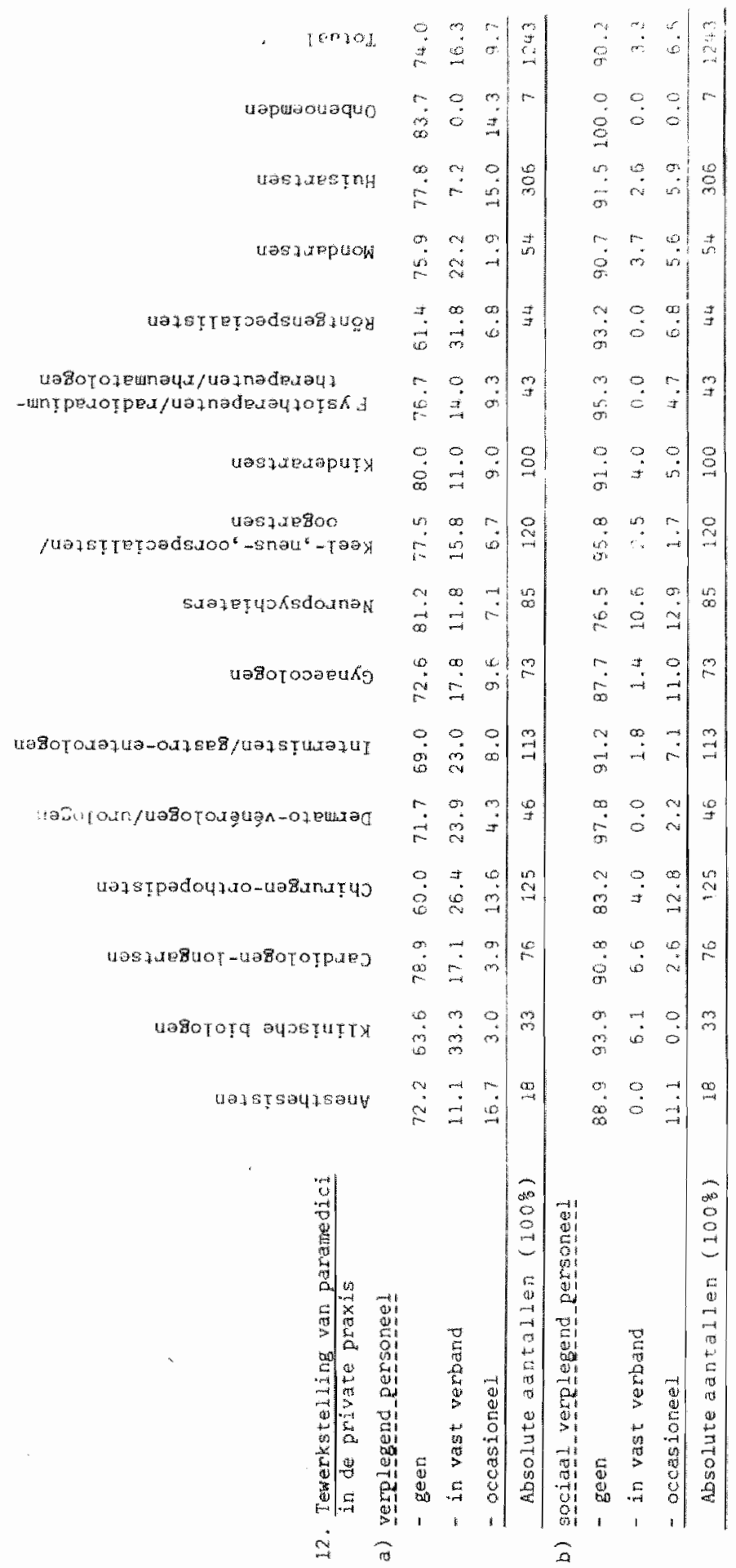




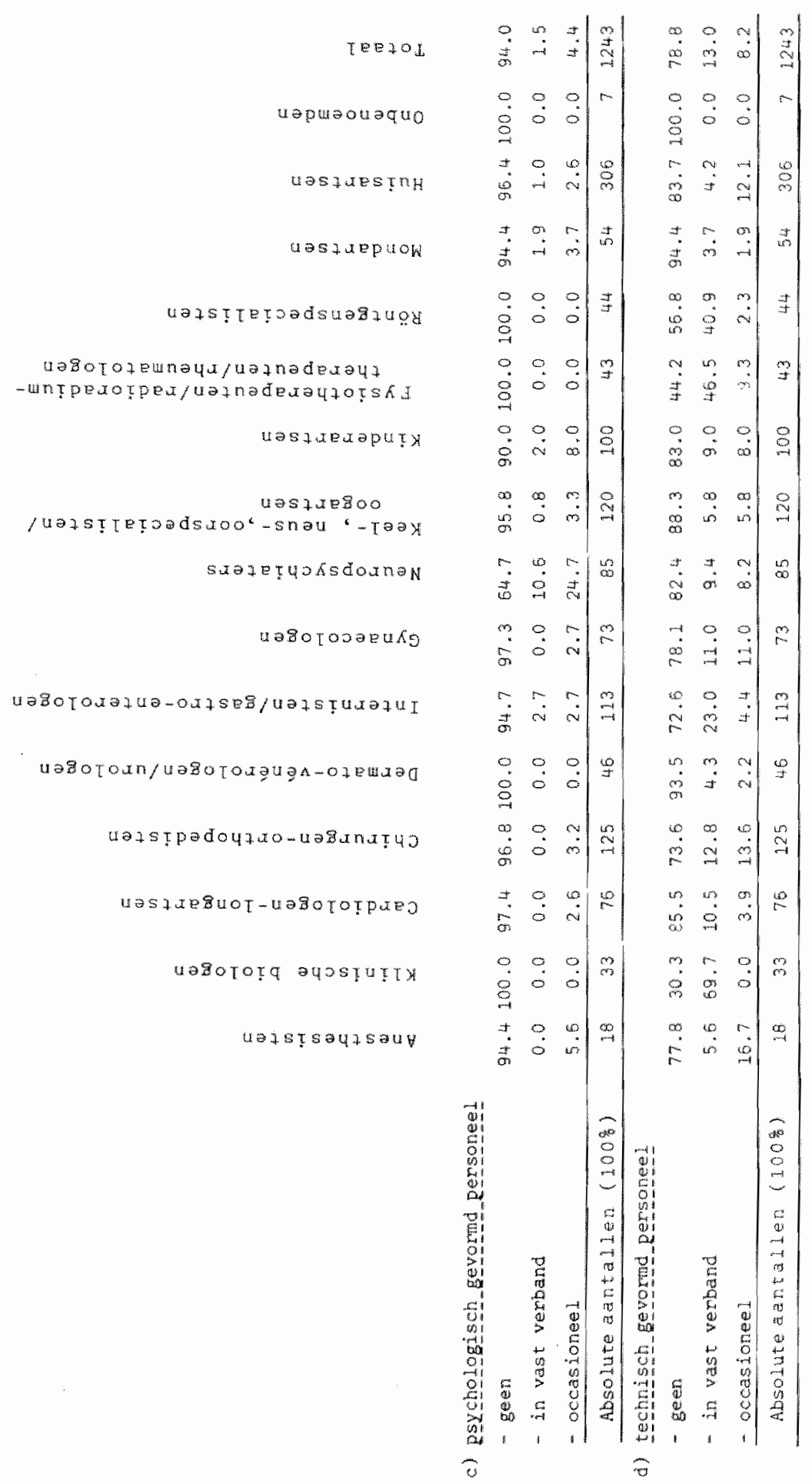




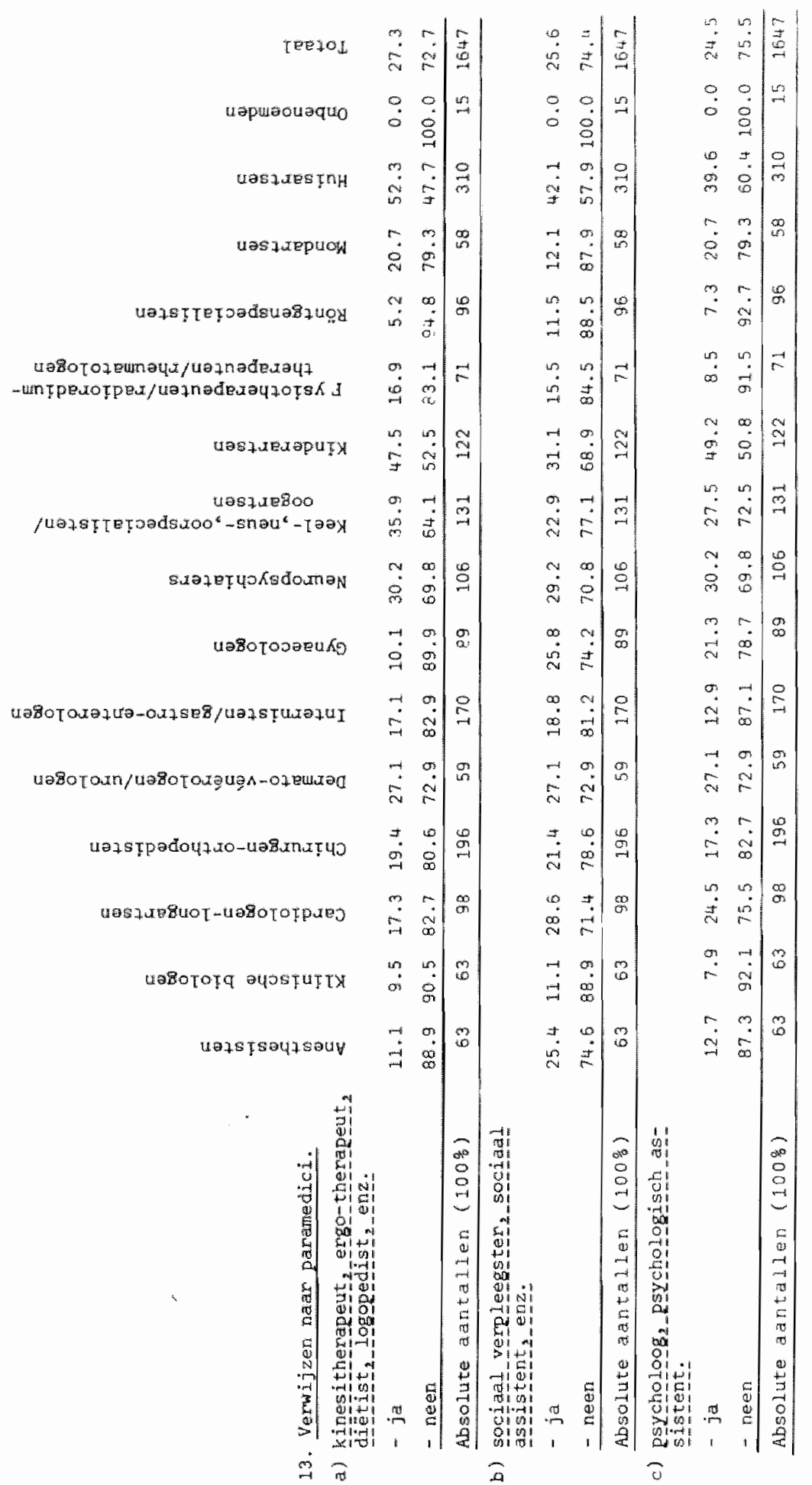




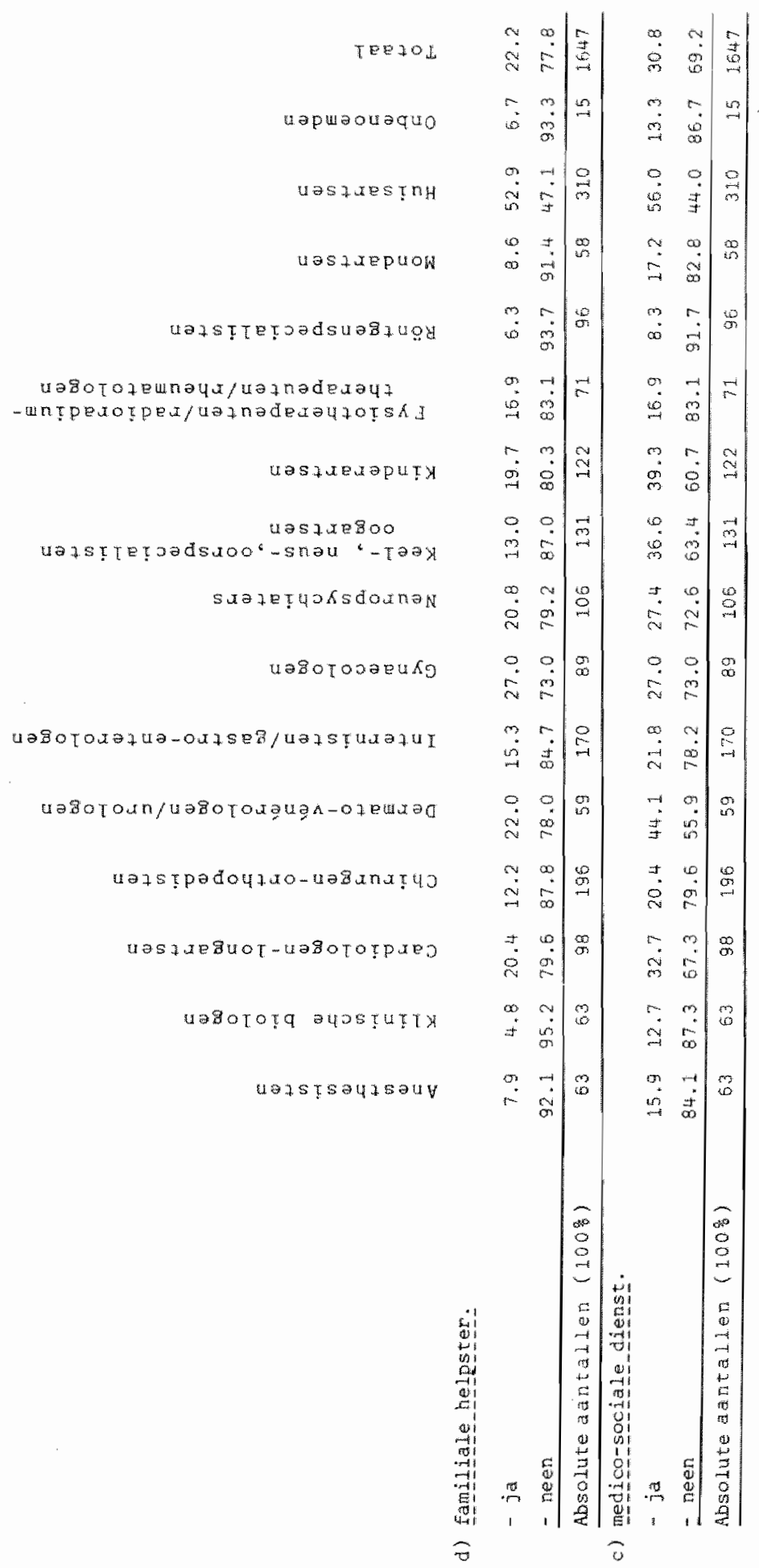




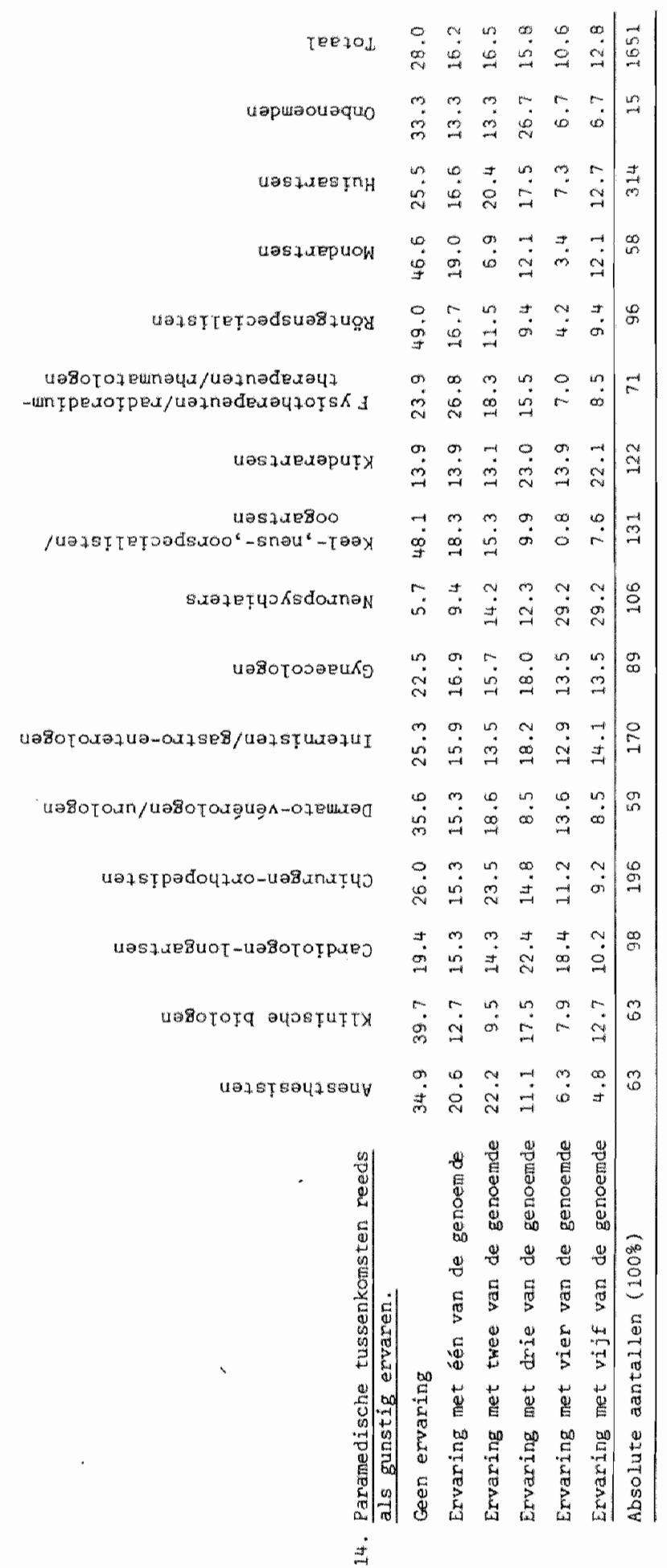




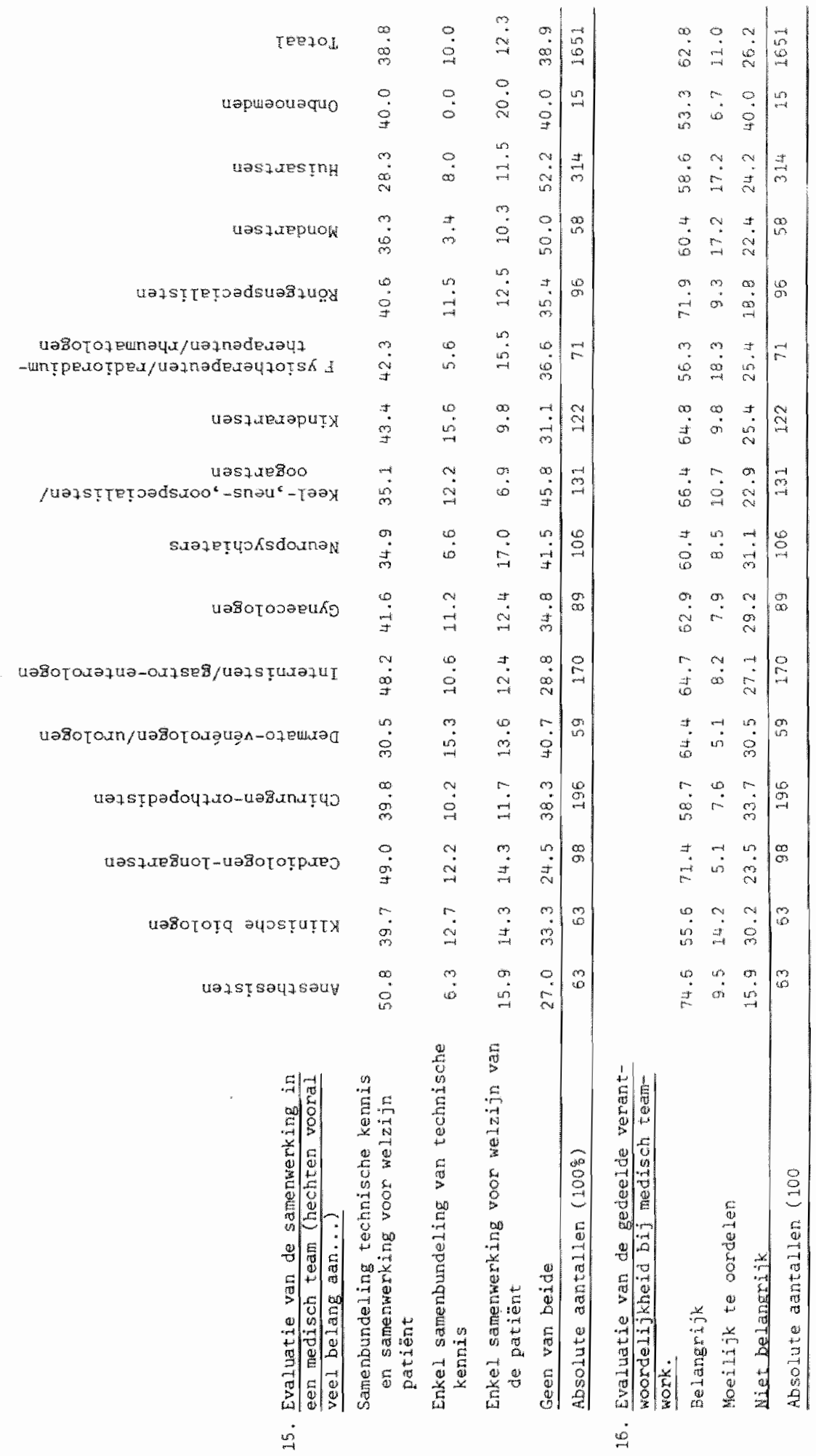




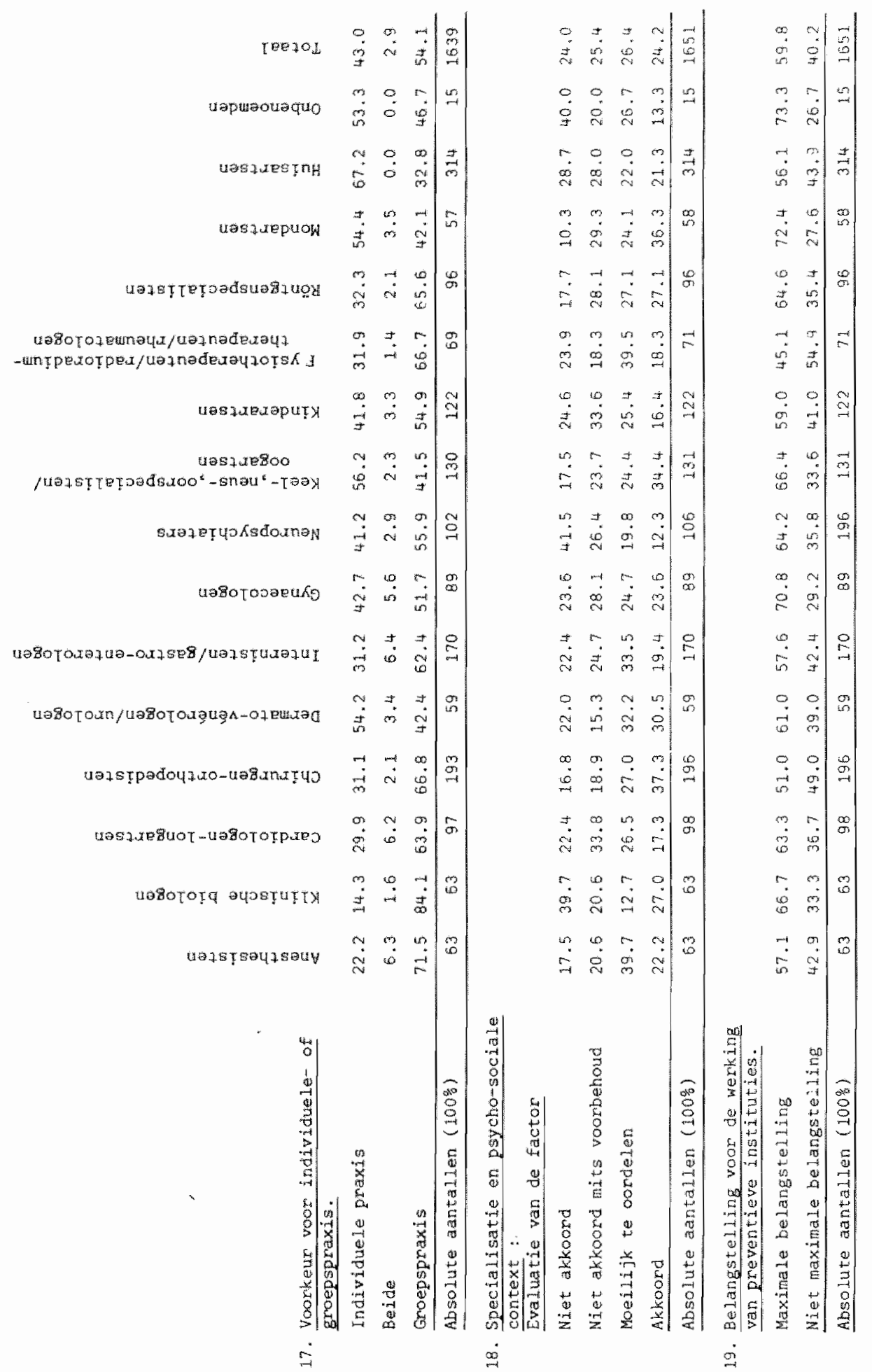




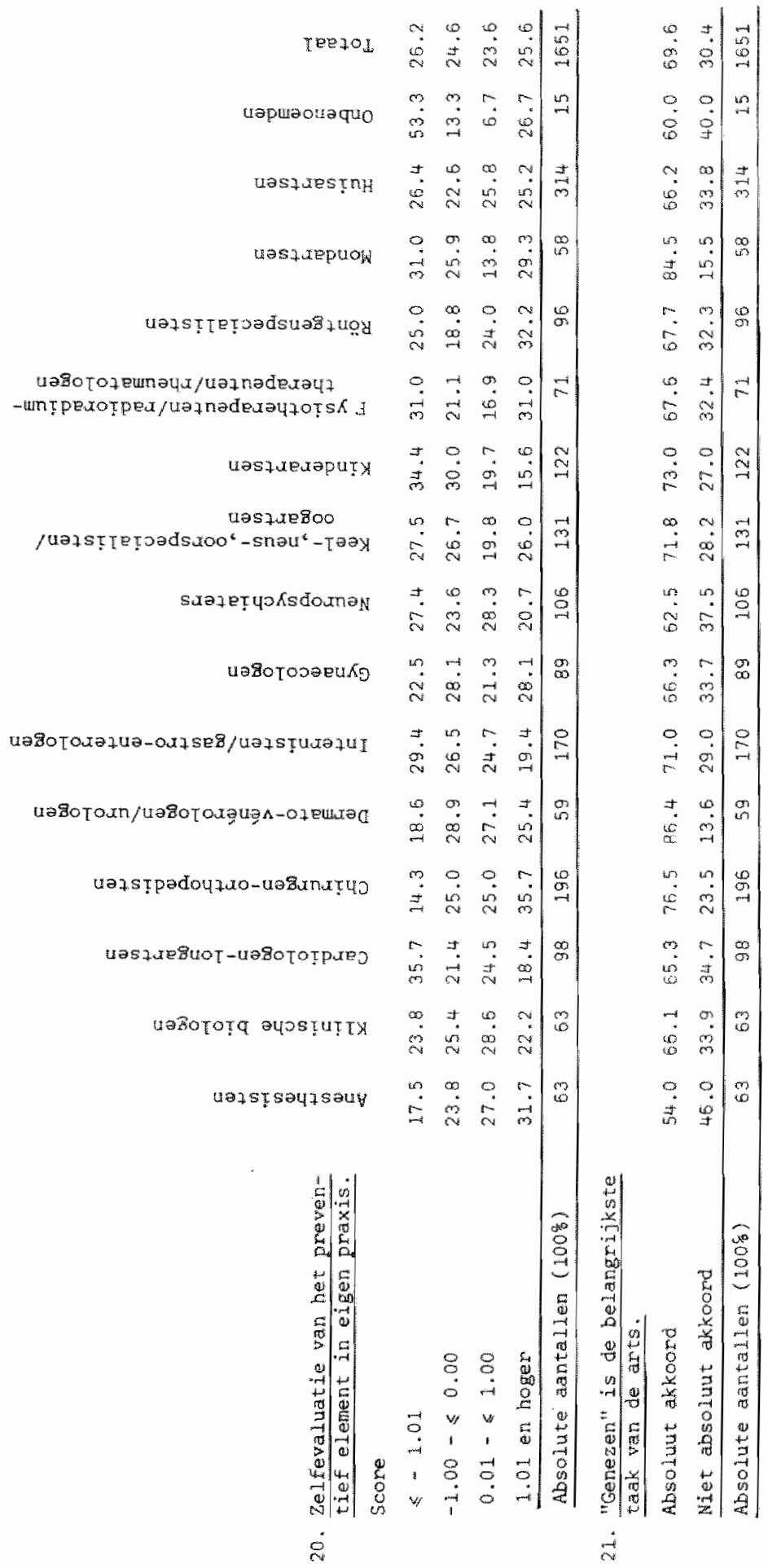




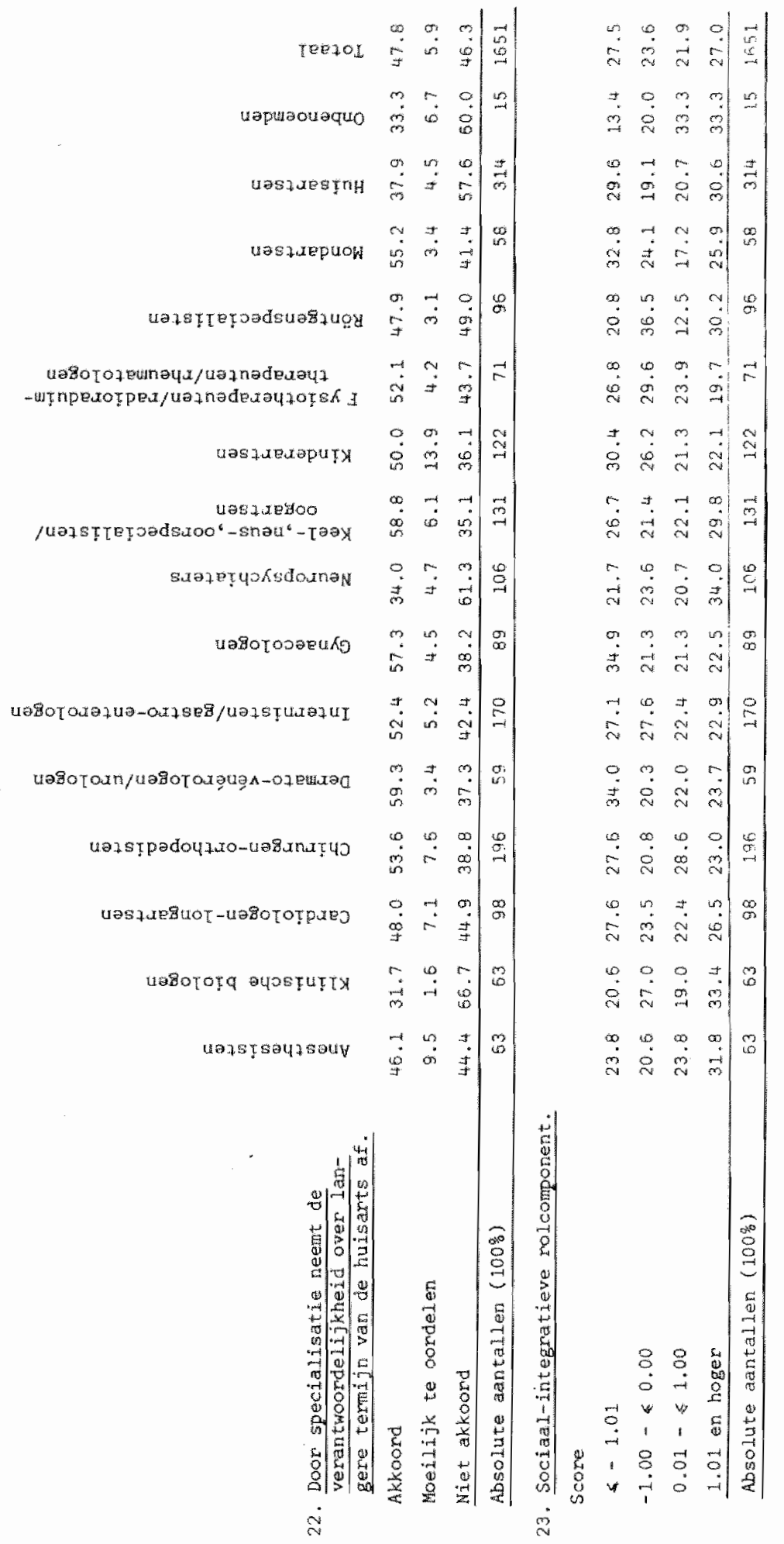




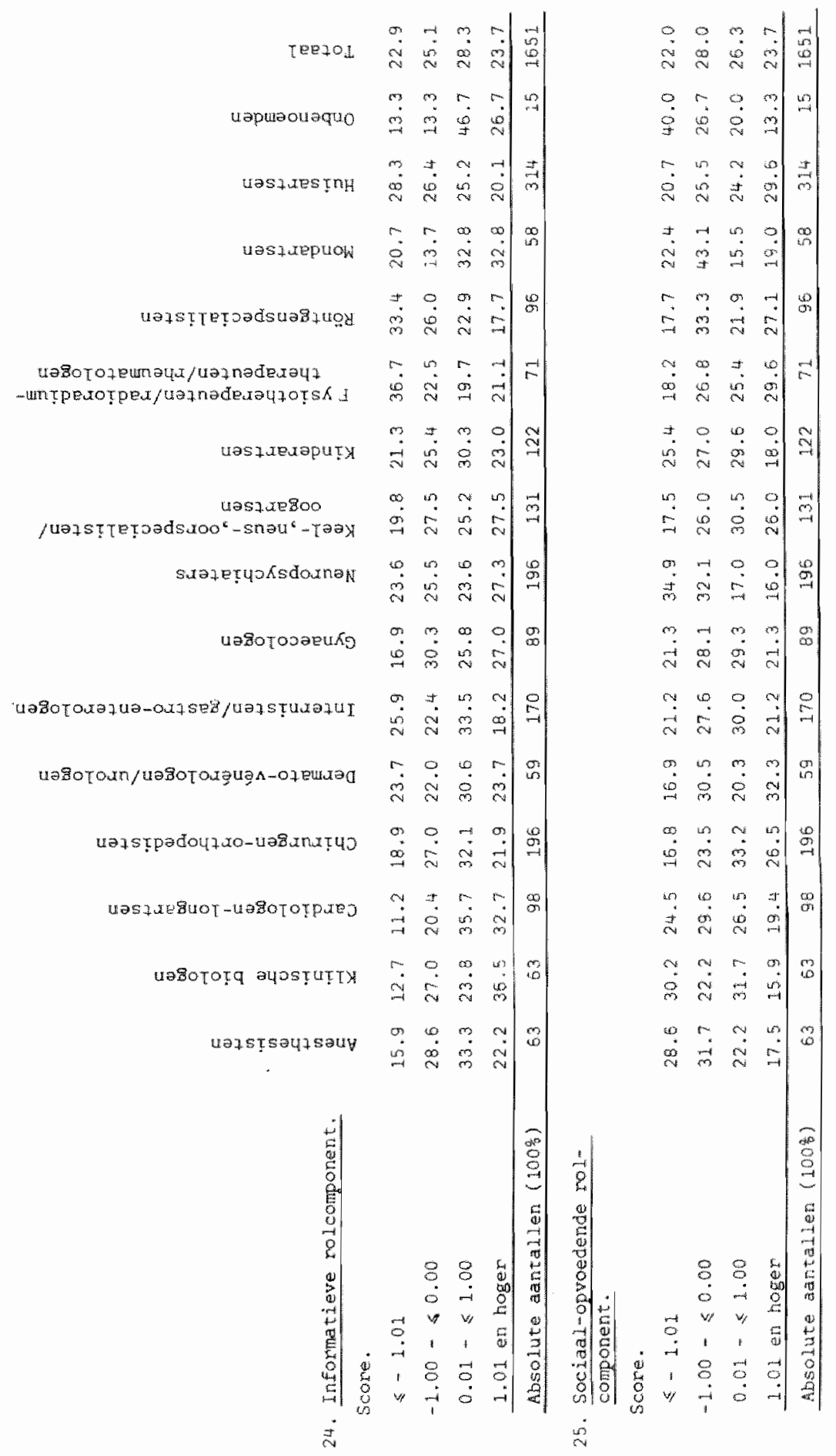




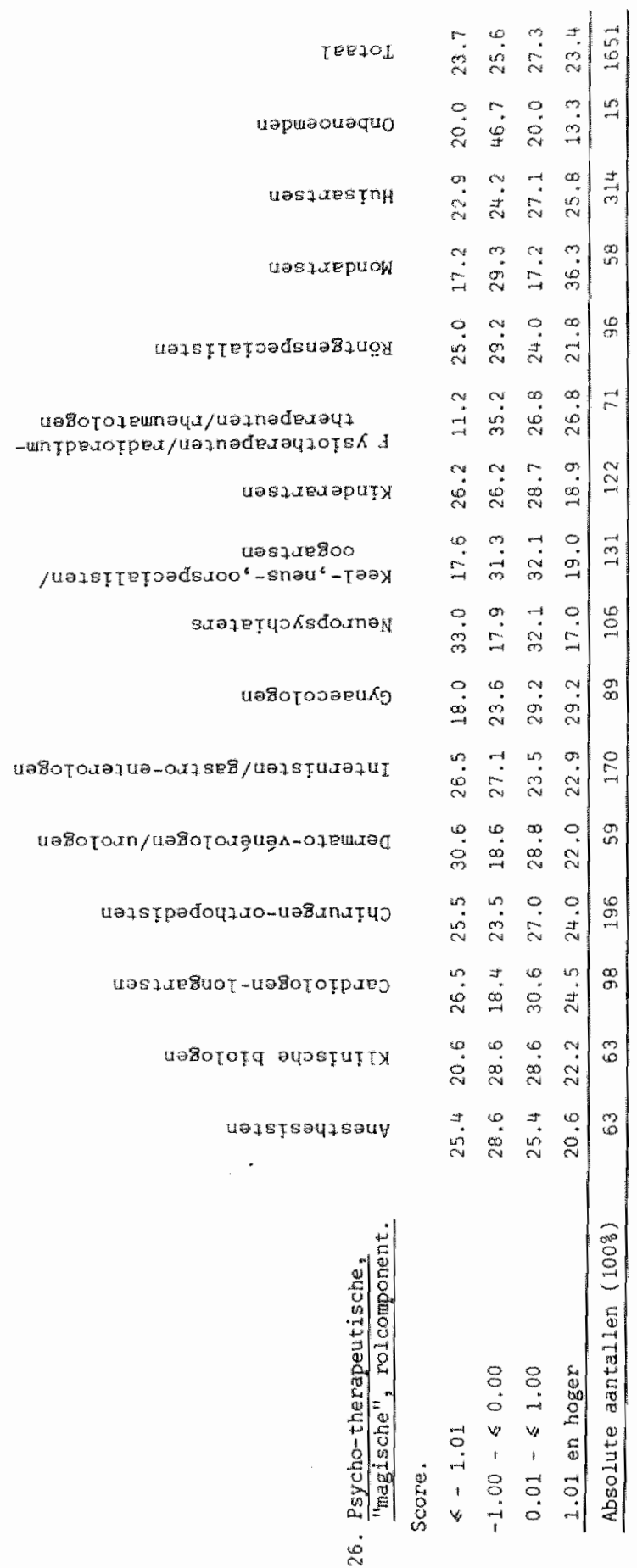


APPENDIX III. FREQUENTIETABELLEN - Significante resultaten. (*)

Tabel 1.

Evaluatie van medisch teamwerk en aard van de praxis

\begin{tabular}{|l|c|c|c|}
\hline Hechten voral belang aan & \multicolumn{2}{|c|}{ Aard van de praxis } & \\
\cline { 2 - 4 } & private praxis & verbonden praxis & Totaal \\
\hline $\begin{array}{l}\text { zowel de samenbundeling } \\
\text { van de technische kennis } \\
\text { als het samenwerken voor } \\
\text { het welzijn van de patient } \\
\text { enkel de samenbundeling } \\
\text { van de technische kennis } \\
\text { enkel het samenwerken voor } \\
\text { het welzijn van de patient } \\
\text { geen van beide }\end{array}$ & 35.3 & 49.4 & 38.8 \\
\hline Absolute aantallen $(100 \%)$ & 9.6 & 11.8 & 10.1 \\
\hline
\end{tabular}

$$
\begin{aligned}
& x^{2}: 35.14 ; \text { dE. } 3 \quad P:<.0001 \\
& Y:-0.265
\end{aligned}
$$

Tabe1 2 .

Sociaal milieu van de praktijk en voorkeurshouding inzake aard var

\begin{tabular}{|c|c|c|c|c|}
\hline \multirow[b]{2}{*}{$\begin{array}{l}\text { Sociali milieu van de } \\
\text { praktijk }\end{array}$} & \multicolumn{3}{|c|}{ Voorkeur voor } & \multirow[b]{2}{*}{$\begin{array}{c}\text { Absolute } \\
\text { andaller } \\
(100 \%)\end{array}$} \\
\hline & $\begin{array}{c}\text { individuele } \\
\text { praxis }\end{array}$ & beide & $\begin{array}{l}\text { Eroeps- } \\
\text { praxis }\end{array}$ & \\
\hline platteland & 67.7 & - & 32.3 & 133 \\
\hline stad: Iagere sociale lagen & 39.3 & 3.3 & 57.4 & 540 \\
\hline stad:hogere sociale lagen & 51.0 & $2 \cdot 8$ & 46.2 & 353 \\
\hline stad:gemengd & 42.3 & 4.1 & 53.6 & 194 \\
\hline wotaa 1 & 44.9 & 3.0 & 52.1 & 1520 \\
\hline
\end{tabular}
de praxis

$$
\begin{aligned}
& x^{2}: 46.52 ; \text { df. } 6 \text { P }:<.0001 \\
& y: 0.02
\end{aligned}
$$

(*) Alle resultaten worden ter verduidelijking in procenten uitgedrukt. 


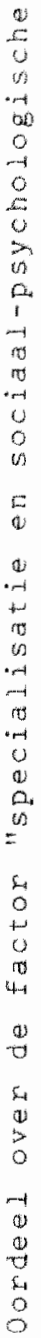

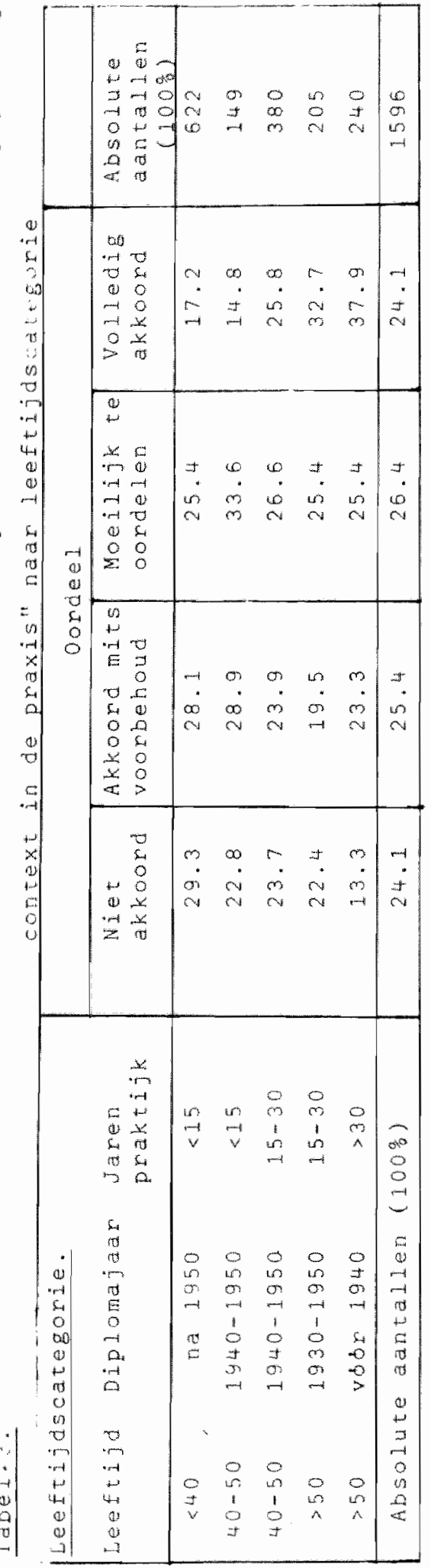

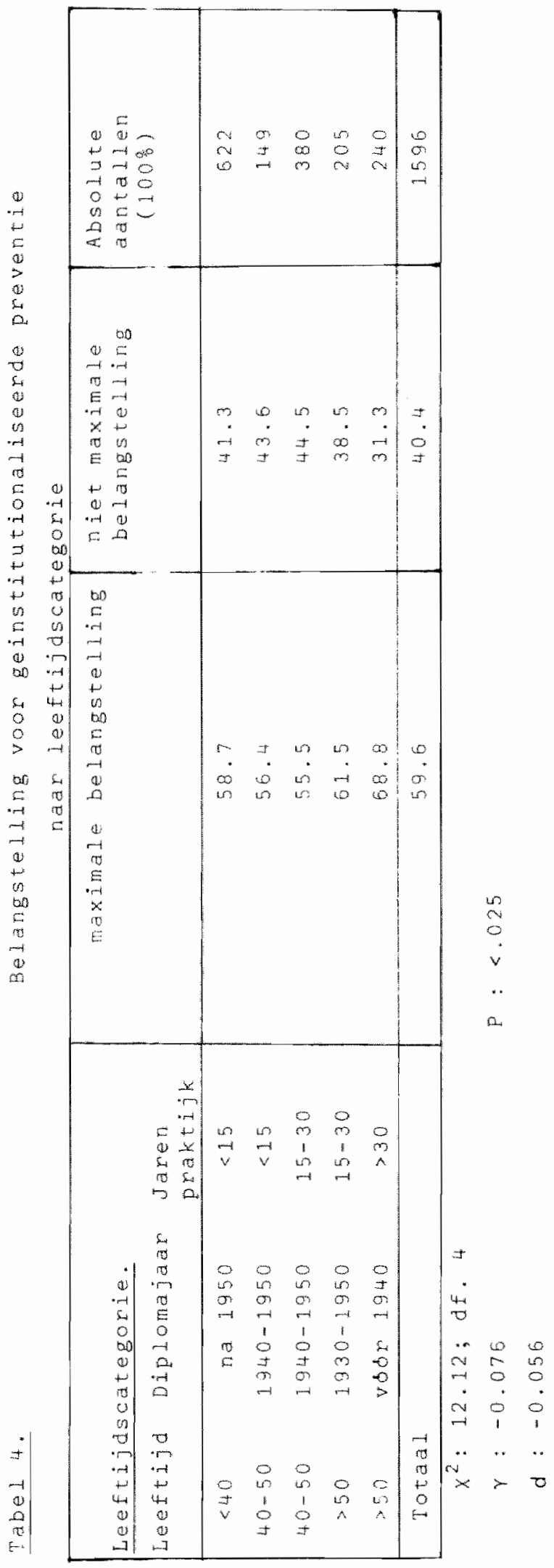


mabel 5

Zelfevaluatie op preventief gebied in eigen prexis en ecologiach milieu van de praktijk

\begin{tabular}{|c|c|c|c|c|c|}
\hline \multirow[t]{2}{*}{ Ecologiseh milieu } & \multicolumn{4}{|c|}{ Zelfevaluat $\dot{0}$ : score } & \multirow[b]{2}{*}{$\begin{array}{c}\text { Absolute } \\
\text { antalle } \\
(1003)\end{array}$} \\
\hline & -1.01 & $-1.00-\leqslant 0.00$ & $0.01-\leqslant 1.00$ & 1.01 & \\
\hline platteland & 19.5 & 20.1 & 24.5 & 35.9 & 159 \\
\hline kleine stad & 25.1 & 30.8 & 21.5 & $22 \cdot 6$ & 270 \\
\hline stad & 27.2 & 23.7 & 24.3 & 24.3 & 1123 \\
\hline stadtplateland & 39.5 & 23.2 & 11.6 & 25.6 & 13 \\
\hline totaal & 26.4 & 24.6 & 23.5 & 25.6 & 1604 \\
\hline
\end{tabular}

Tabel 6 .

Zelfevaluatie op preventief viak en evaluatie van de factor "specialisatie en social-psychologische context in de praxis

\begin{tabular}{|c|c|c|c|c|c|}
\hline \multirow{2}{*}{$\begin{array}{l}\text { evaluatie van de } \\
\text { factor : "Specialisa- } \\
\text { tie en sociaal-psycho- } \\
\text { logische context in de } \\
\text { praxis". }\end{array}$} & \multicolumn{4}{|c|}{ Zelfevaluatie: scoro } & \multirow[b]{2}{*}{$\begin{array}{c}\text { Absolute } \\
\text { antallen } \\
(100 \mathrm{w})\end{array}$} \\
\hline & $\leqslant-1.01$ & $-1.00-\leqslant 0.00$ & $0.01-\leqslant 1.00$ & 1.01 & \\
\hline niet akkoord & 39.4 & 27.3 & 23.2 & 10.1 & 396 \\
\hline $\begin{array}{c}\text { akkoord mits roor- } \\
\text { behoud }\end{array}$ & 29.0 & 29.0 & $25 \cdot 5$ & 16.4 & 420 \\
\hline moeilijk te oordelen & 24.3 & 22.7 & 21.8 & 31.2 & 436 \\
\hline volledig akkoond & $12 \cdot 2$ & $19 \cdot 2$ & $24 \cdot 1$ & 44.5 & 402 \\
\hline totaal & 26.2 & 24.5 & 23.6 & 25.6 & 1654 \\
\hline
\end{tabular}

$x^{2}: 182.09 ;$ df. 9 P: 0.0001

Y: -0.34

Tabej 7 .

Belang gebocht a an het curatef elant in do praxis en de leeftijdscategorie

\begin{tabular}{|c|c|c|c|c|c|}
\hline \multicolumn{3}{|c|}{ Leeftijdscategorie. } & \multicolumn{3}{|c|}{ "Genezen" is de bolangrijkste tak van de ares } \\
\hline Leefti & $\begin{array}{l}\text { dscategor } \\
\text { Diploma- } \\
\text { jaar }\end{array}$ & $\begin{array}{c}\text { Jaren } \\
\text { arakt } j k \\
\end{array}$ & Absolut akkoord & $\begin{array}{c}\text { Niet absoluut } \\
\text { akkoond }\end{array}$ & $\begin{array}{l}\text { Abeoluto } \\
\text { antalien } \\
\quad(1009)\end{array}$ \\
\hline$<40$ & na 1950 & $<15$ & 60.6 & 39.4 & 620 \\
\hline $40-50$ & $1940-1950$ & $<15$ & 58.4 & 41.6 & 149 \\
\hline $40-50$ & $1940-1950$ & $15-30$ & 74.9 & 25.1 & 379 \\
\hline$>50$ & $1930-1950$ & $15-30$ & 80.0 & 20.0 & 205 \\
\hline$>50$ & voon 1940 & $>30$ & B2. 0 & 18.0 & 239 \\
\hline & $\operatorname{taa} 1$ & & 69.5 & 30.5 & 1592 \\
\hline
\end{tabular}

$x^{2}: 65.23 ;$ df. 4 y $:-0.310$ d $:-0.130$ p: <.0001. 
tabel 8.

Belang gehecht atan het curatief element

in de praxis en evaluatie van het medisch tear

\begin{tabular}{|c|c|c|c|}
\hline \multirow[b]{2}{*}{ Warderen: } & \multicolumn{3}{|c|}{$\begin{array}{l}\text { "Gerezen" is de belangrijkste tak wan de } \\
\text { ants }\end{array}$} \\
\hline & absoluut akkoord & $\begin{array}{l}\text { niet absolut } \\
\text { akkoord }\end{array}$ & $\begin{array}{l}\text { Absolute } \\
\text { antalien } \\
(100 \%)\end{array}$ \\
\hline $\begin{array}{l}\text { zowel de samenbundeling } \\
\text { van de technische kennis } \\
\text { als het samenwerken voor } \\
\text { het welzijn van de patient } \\
\text { enkel de samenbundeling } \\
\text { van de technische kennis } \\
\text { enkel het samenkerken voor } \\
\text { het welzijn van de patient } \\
\text { get van heile }\end{array}$ & $\begin{array}{l}69.1 \\
70.4 \\
61.9\end{array}$ & $\begin{array}{l}30.9 \\
29.0 \\
38.1\end{array}$ & $\begin{array}{l}165 \\
203 \\
643\end{array}$ \\
\hline totaa 1 & 69.6 & 30.4 & 1650 \\
\hline
\end{tabular}

$x^{2}: 36.09 ;$ df. $3 \quad P:<.0001$

$\gamma: 0.253$

Tabel 9.

Evaluatie van het curatief element in de praxis en evaluatie van de factor "specialisatie en sociaal-psychologische context in de praxis"

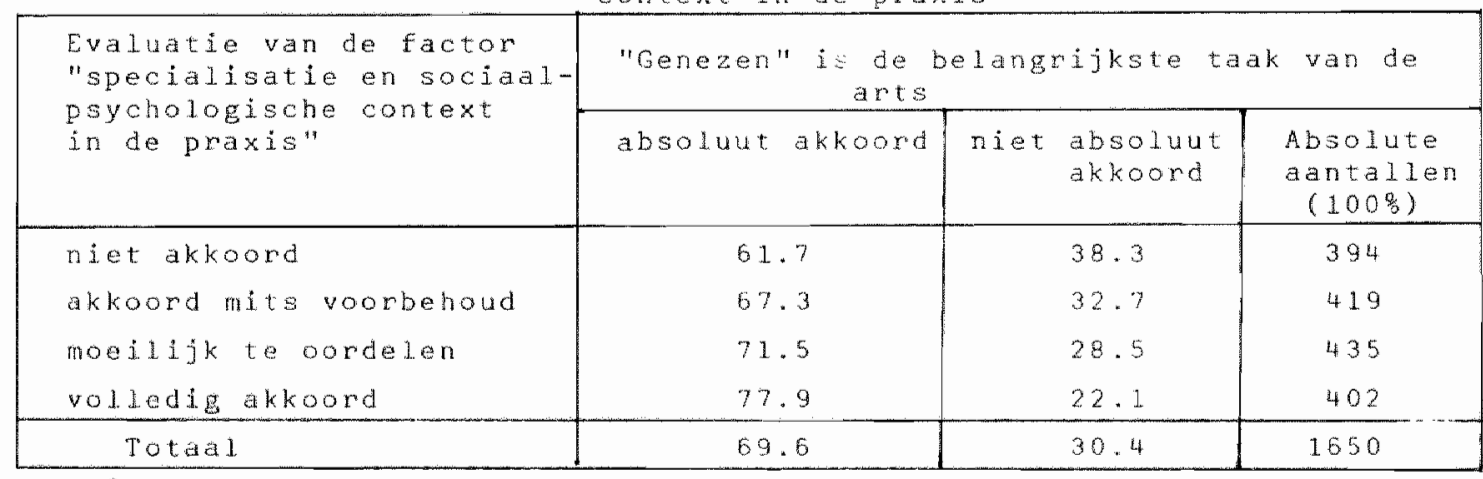

$x^{2}: 26.46 ;$ df. $3 \quad P: .0001$

$y:-0.204$ 
Tabel 10

oorded over de uitsprak :

"Door het toenemend antal specialistan neemt de verantwoordelijkheid van de husarts ower een langere ternijn af".

\begin{tabular}{|c|c|c|c|c|c|c|}
\hline \multicolumn{3}{|c|}{ Leetijdscategorie. } & \multicolumn{3}{|c|}{ oondeel } & \multirow[b]{2}{*}{$\begin{array}{c}\text { Absolute } \\
\text { andallen } \\
(100)\end{array}$} \\
\hline Leeftijd & DĹplomajaar & $\begin{array}{l}\text { Jamen } \\
\text { praktijk }\end{array}$ & Akkoore & $\begin{array}{l}\text { Moeilijk te } \\
\text { oordelen }\end{array}$ & $\begin{array}{c}\text { Niet } \\
\text { akkoord }\end{array}$ & \\
\hline$<40$ & na 1950 & $<15$ & 37.3 & 7.9 & 54.8 & 622 \\
\hline $40-50$ & $1940-1950$ & $<15$ & 40.3 & 4.7 & 55.0 & 149 \\
\hline $40-50$ & $1940-1950$ & $15-30$ & 50.0 & 5.5 & 44.5 & 380 \\
\hline$>50$ & $1930-1950$ & $15-30$ & 58.5 & 3.9 & 37.6 & 205 \\
\hline$>50$ & vobm 1940 & $>30$ & 67.5 & 4.6 & 27.9 & 240 \\
\hline \multicolumn{2}{|c|}{ Totaa 1} & & 47.9 & 6.0 & 46.1 & 1596 \\
\hline
\end{tabular}

$x^{2}: 90.89 ;$ df. $8 \quad$ F $:<.0001$

$\Upsilon:-0.285$

d : -0.213

rabel 11

oordeel over de uitsprak :

"Door het toenemend aantal specialisten neemt de verantwoordelijkhejd van de huisarts over een langere temijn aft en evaluatie van de factor:"specialisatie en sociaal-psychologische context in de praxis.

\begin{tabular}{|c|c|c|c|c|}
\hline \multirow{2}{*}{$\begin{array}{l}\text { Evaluatie van de fac- } \\
\text { tor : specialisatie en } \\
\text { sociad - psychologische } \\
\text { context in de praxis. }\end{array}$} & \multicolumn{3}{|c|}{ oordeel } & \multirow[b]{2}{*}{$\begin{array}{c}\text { Absolute } \\
\text { antalien } \\
(100 \text { s) }\end{array}$} \\
\hline & a kkoord & $\begin{array}{l}\text { moeilijk te } \\
\text { oordelen }\end{array}$ & $\begin{array}{l}\text { niet } \\
\text { akkoord }\end{array}$ & \\
\hline niet akkoord & - & 5.1 & 94.9 & 396 \\
\hline akkoord, mits voorbehoud & 43.8 & 4.8 & 51.4 & 420 \\
\hline moeilijk te oordelen & 59.9 & 7.3 & 32.8 & 436 \\
\hline volledig akkoord & 85.3 & 6.2 & 7.5 & 402 \\
\hline Totaal & 47.9 & 5.9 & 46.2 & 1654 \\
\hline
\end{tabular}

$x^{2}: 684.49 ;$ df. 6 P : 6.0001

$\gamma:-0.782$ 
Tabel 12.

oordeel over de uitsprak :

"Door het toenemend aantal specialisten beemt de verantwoordelijkheid van de huisats over

Door het toenemend aarial specialisneent do verantwoordelijkheid van de hulsarts over een langere termijn af ak koord moeilijk te oordeler niet akkoord absolute atatalien $(100 \%)$ een langere termijn af en zelfevaluatie in de eigen praxis op preventief vlak*.

\begin{tabular}{|c|c|c|c|c|}
\hline \multicolumn{4}{|c|}{ Zelfevaluatie } & \multirow[b]{2}{*}{ Totaal } \\
\hline$<-1.01$ & $-1.00-<0.00$ & $0.01-\leqslant 1.00$ & $\begin{array}{c}1.01 \text { en } \\
\text { hoger }\end{array}$ & \\
\hline 41.1 & 47.5 & 43.5 & 59.2 & 47.1 \\
\hline 3.7 & 7.4 & 5.6 & 6.8 & 5.9 \\
\hline 55.2 & 45.1 & 50.9 & 34.3 & 45.2 \\
\hline 433 & 406 & 391 & 424 & 1654 \\
\hline
\end{tabular}

$x^{2}: 46.17 ; d E .6$

$p:<.0001$

$\gamma: 0.176$

$d: 0.13$

Tabej. 13

Belang geheoht an het curatief element in de praxis en verantwoordelijkheid van de huisarts.

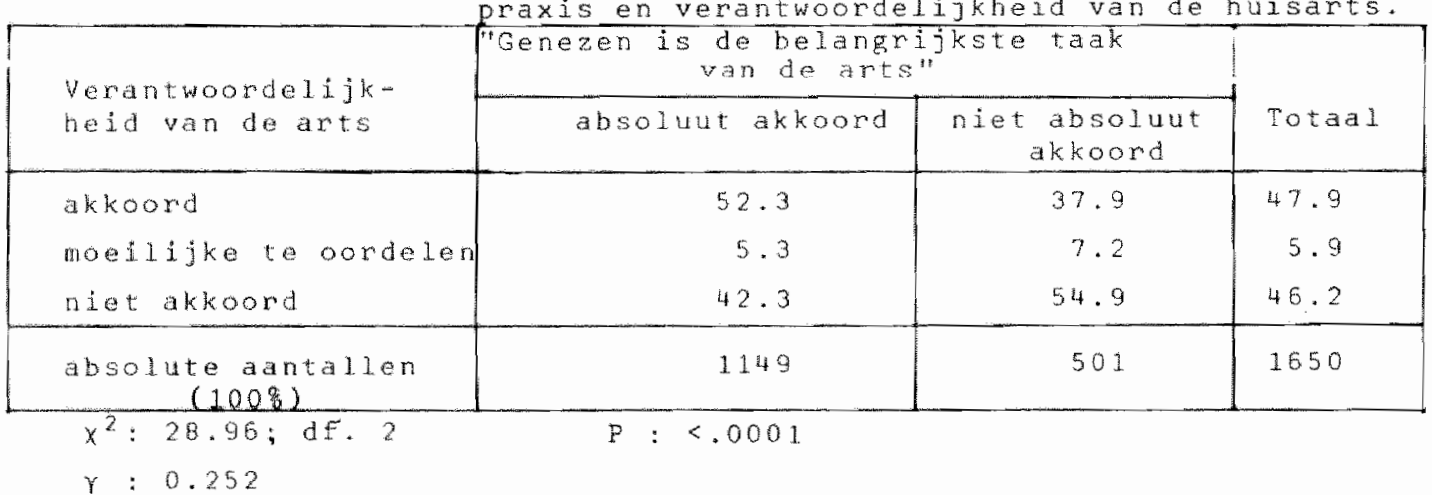




$$
\text { 瞍 }
$$


$-196-$

Social-integratieve rolcomponent

Tabel 15

en evaluatie yan da opleiding.

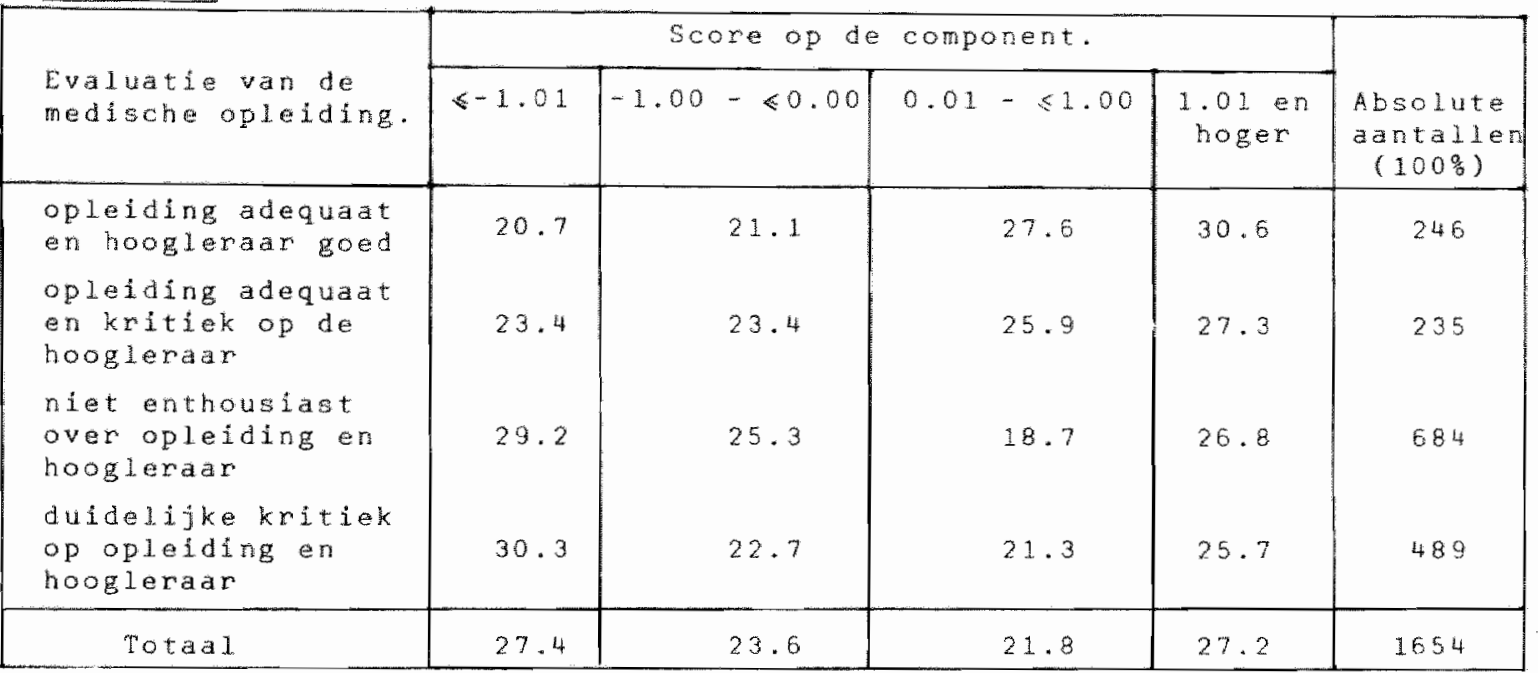

$x^{2}: 19.44 ;$ df. 9

$P: .025$

$\gamma: 0.08$

Tabe 1.16.

Sociaal-integratieve rolcomponent en wardering van het medisch team-werk.

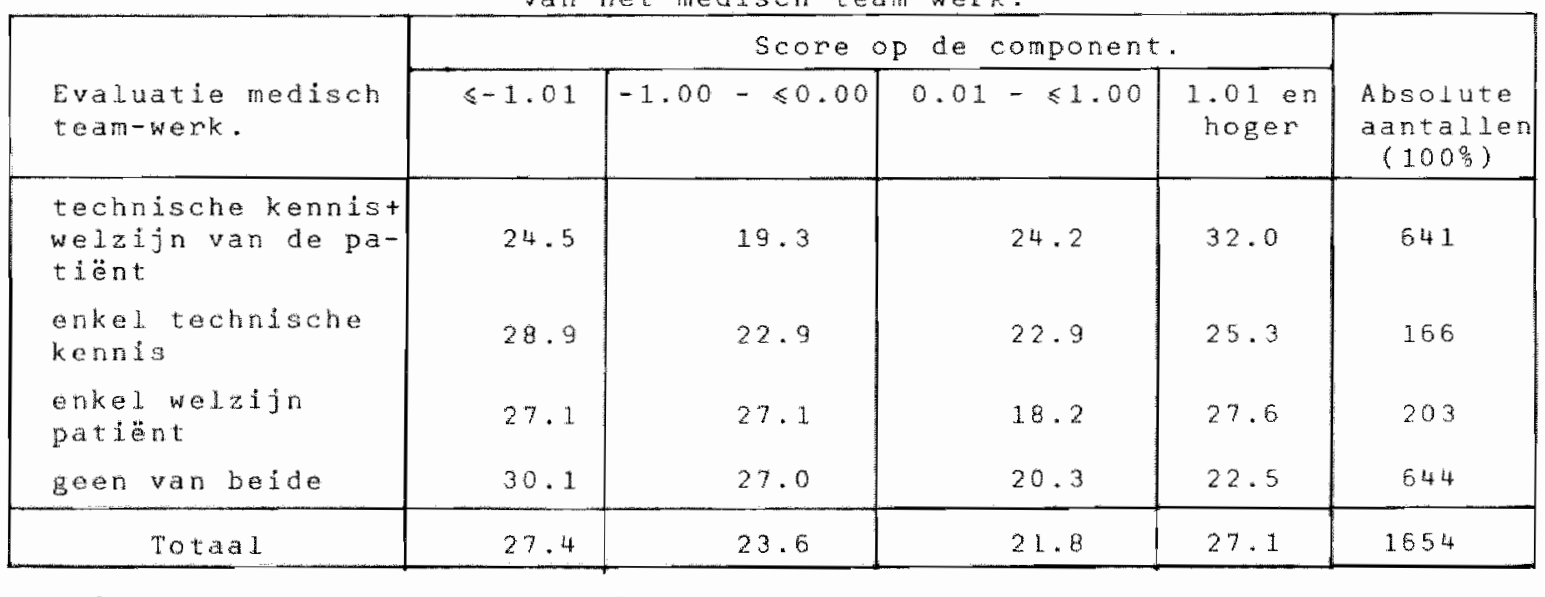

$x^{2}: 27.46 ;$ di 9

$P: .004$

$\gamma: 0.13$ 


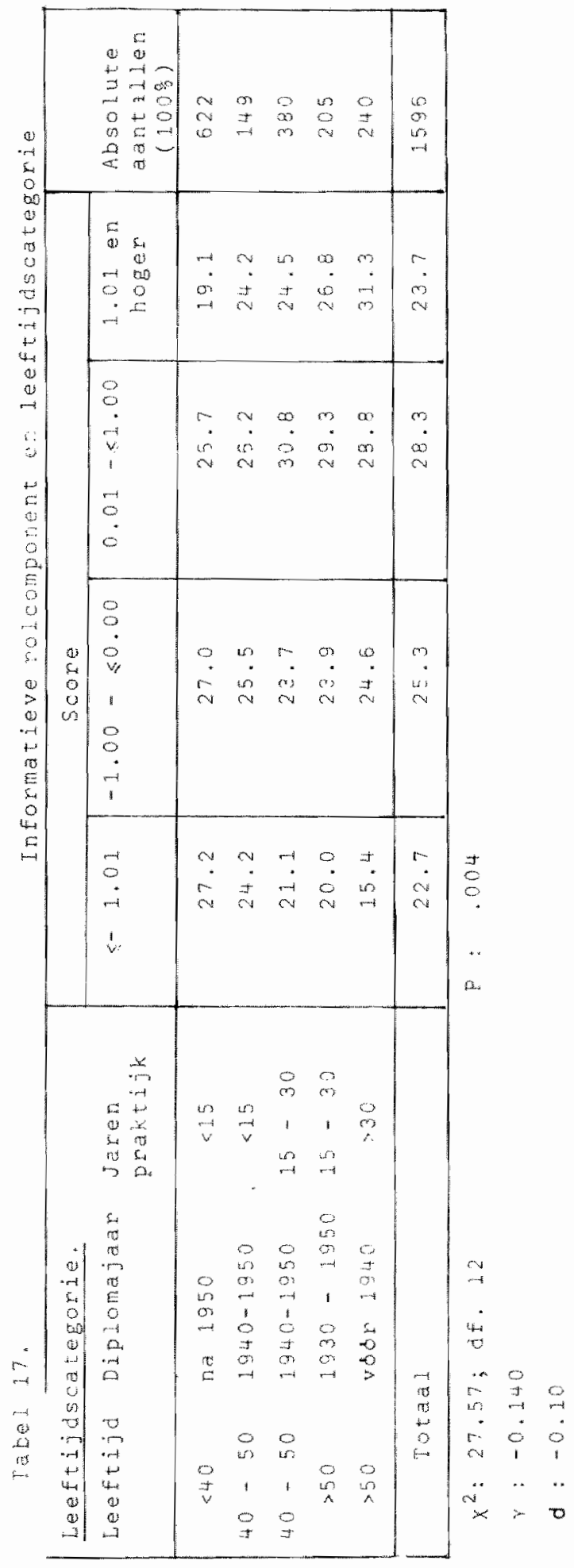


Tabe 18

Informatieve rolcomponent en evaluatie van de medische opleiding.

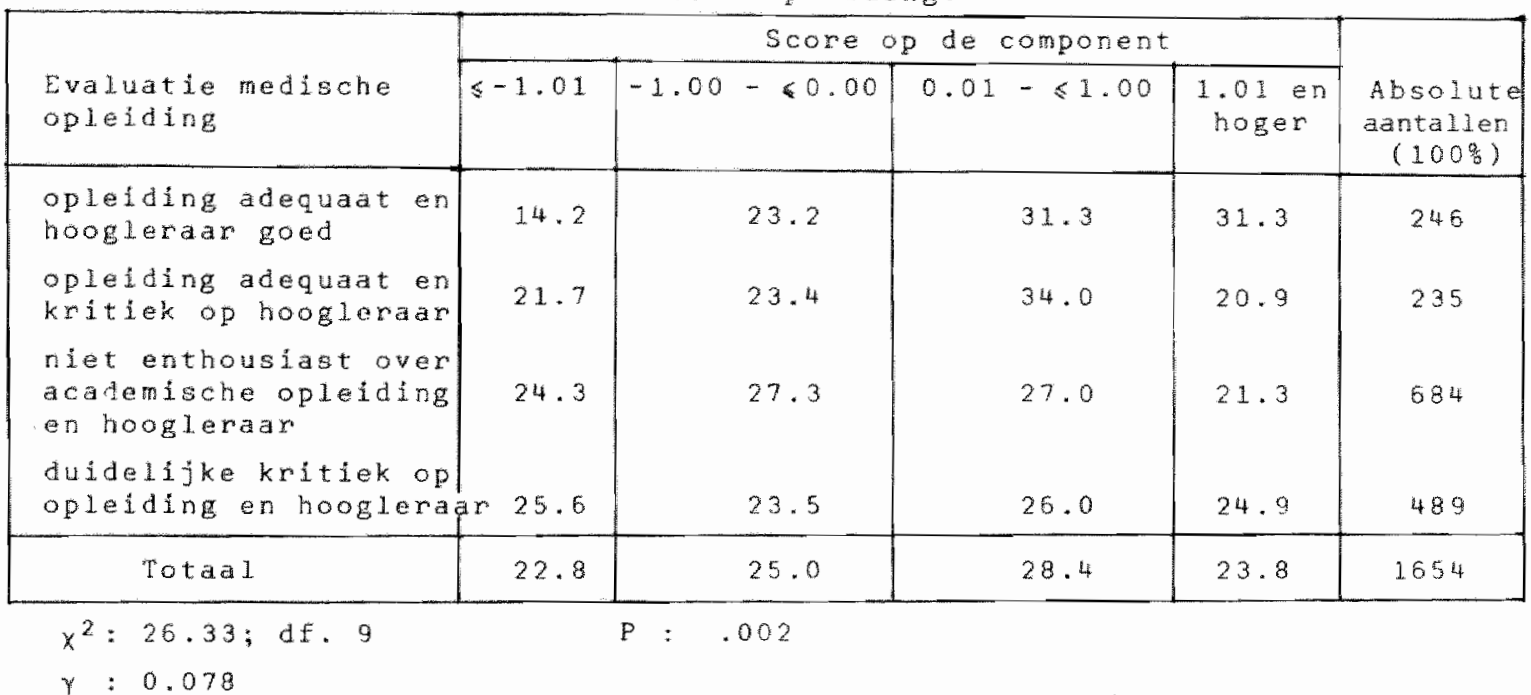

Tabe1. 19.

Informatieve rolcomponent en ecologisch milieu van de praktijk.

\begin{tabular}{|c|c|c|c|c|c|c|c|}
\hline \multirow[b]{2}{*}{$\begin{array}{l}\text { Ecologisch milieu } \\
\text { van de praktijk }\end{array}$} & \multicolumn{6}{|c|}{ Score op de component } & \multirow[b]{2}{*}{$\begin{array}{c}\text { Absolute } \\
\text { antallen } \\
(100 \%)\end{array}$} \\
\hline & $\leqslant-1.01$ & -1.00 & $-\leqslant 0.00$ & 0.01 & -61.00 & $\begin{array}{l}1.01 \text { en } \\
\text { noger }\end{array}$ & \\
\hline platteland & 30.8 & & 30.2 & & 24.5 & $14 \cdot 5$ & 159 \\
\hline kleine stad & 25.8 & & $2^{2} 4.7$ & & 20.2 & 23.3 & 279 \\
\hline stad/platteland & 20.9 & & 32.6 & & 30.2 & 16.3 & 43 \\
\hline Totad & 22.8 & & 24.9 & & 28.6 & 23.6 & 1604 \\
\hline
\end{tabular}

$x^{2}: 20 \cdot 43 ; d f \cdot 9$

$\mathrm{P}: .01$

$\gamma:-0.121$ 
Tabel 20.

Informatieve rolcomponent en social milieu van de praktijk.

\begin{tabular}{|c|c|c|c|c|c|c|c|}
\hline \multirow[b]{2}{*}{$\begin{array}{l}\text { Sociaal milieu van } \\
\text { de praktijk }\end{array}$} & \multicolumn{6}{|c|}{ Scome op de component } & \multirow[b]{2}{*}{$\begin{array}{l}\text { Abminte } \\
\text { aantallen } \\
\text { (1008) }\end{array}$} \\
\hline & $\leqslant-1.01$ & -1.00 & $-\leqslant 0.00$ & 0.01 & -51.00 & $\begin{array}{l}1.01 \text { en } \\
\text { hoger }\end{array}$ & \\
\hline platteland & 33.6 & & 31.3 & & 22.4 & 12.7 & 134 \\
\hline $\begin{array}{c}\text { stad: lagere sociale } \\
\text { lagen }\end{array}$ & 22.8 & & 25.6 & & 27.3 & 24.3 & 845 \\
\hline $\begin{array}{l}\text { stad : hogere sociale } \\
\text { lagen }\end{array}$ & 24.0 & & 22.9 & & 28.8 & 24.3 & 358 \\
\hline stad: gemengd & 16.5 & & 23.7 & & 33.5 & 26.3 & 194 \\
\hline Totaal & 23.3 & & 25.2 & & 28.0 & 23.5 & 1531 \\
\hline
\end{tabular}

$x^{2}: 24.50 ; d f .9$

P: .004

$\gamma:-0.110$

Tabel 21.

Informatieve rolcomponent en evaluatie van de gedeelde verantwordelijkheid bij medisch team-werk.

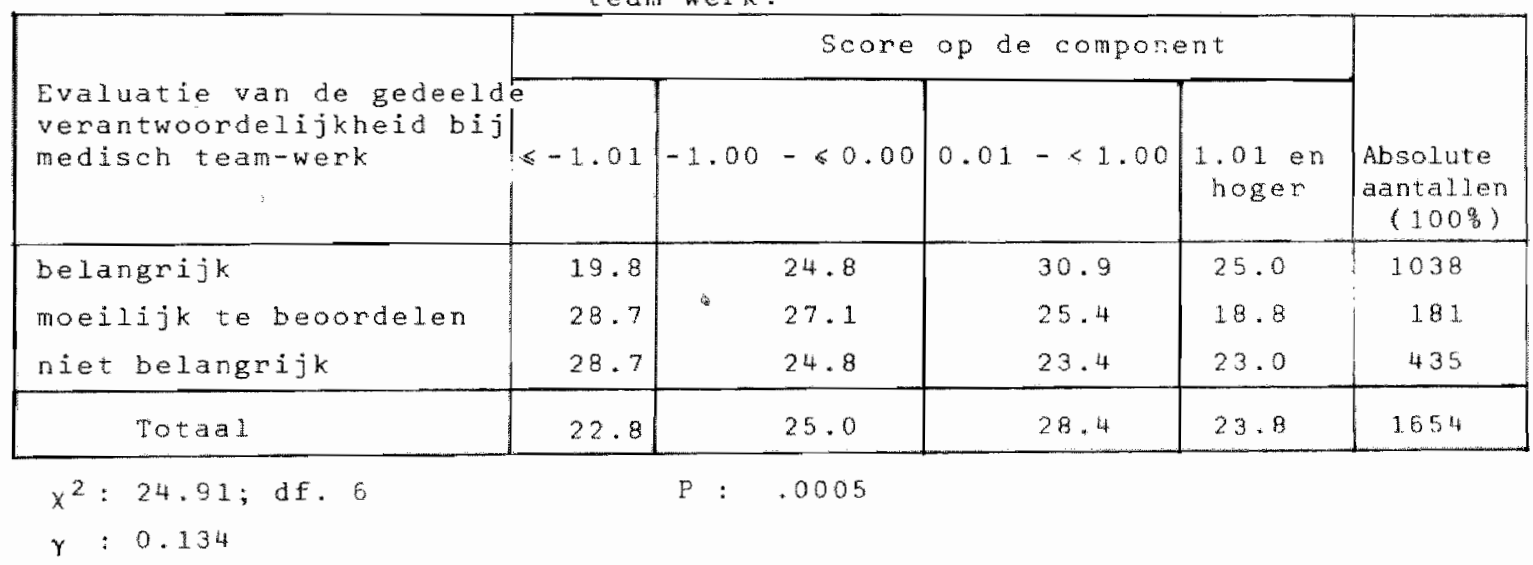


Tabe 22.

Informatieve rolcomponent en evaluatie van het medisch team.

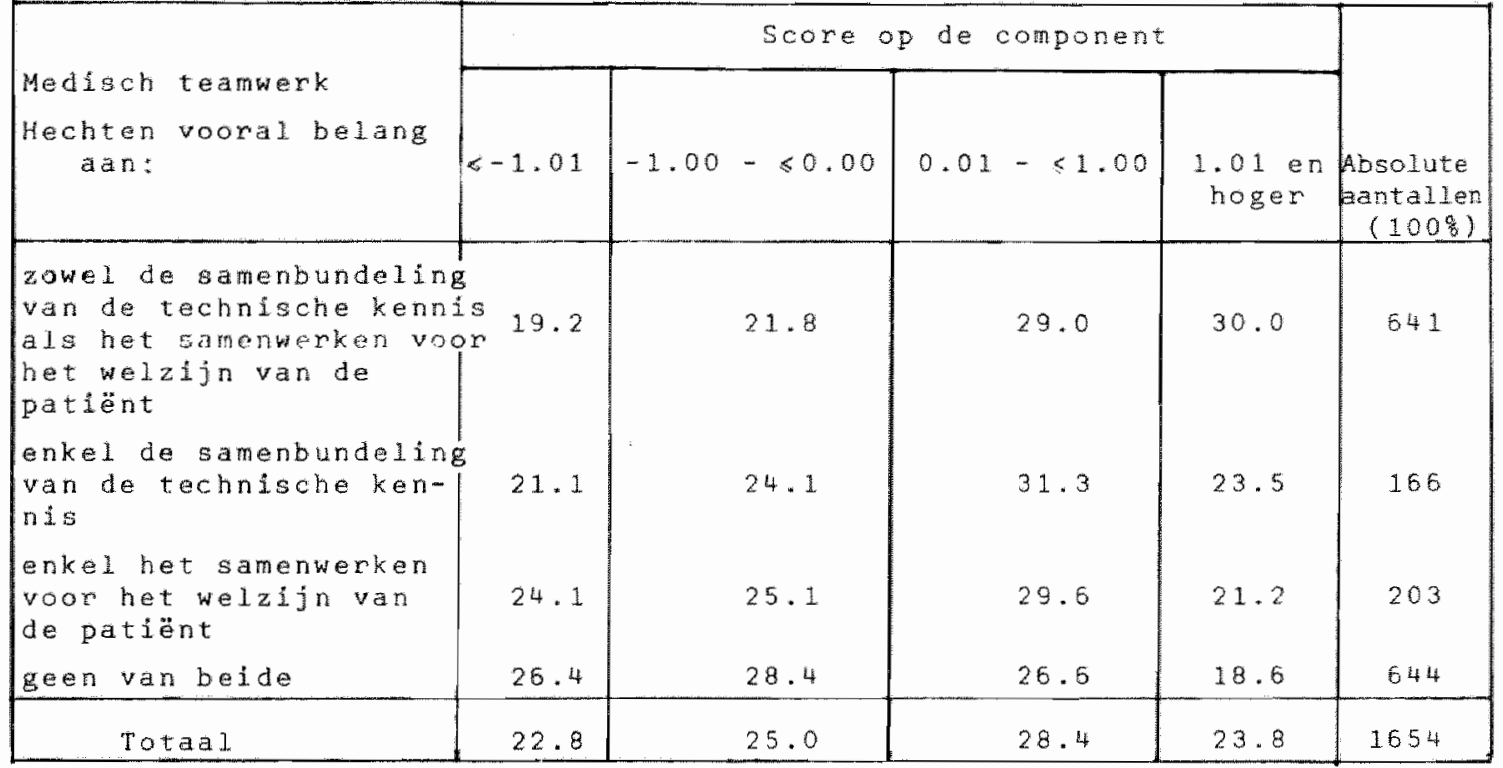

$$
\begin{array}{ll}
x^{2}: 32.76 ; \text { df.9 } & P: .0002 \\
y: 0.160 &
\end{array}
$$

Tabel 23.

\begin{tabular}{|c|c|c|c|c|c|}
\hline \multirow[b]{2}{*}{ Voorkeur voor } & \multicolumn{4}{|c|}{ Score op de component } & \multirow[b]{2}{*}{$\begin{array}{c}\text { Absolute } \\
\text { antallen } \\
(100 \%)\end{array}$} \\
\hline & $<-1.01$ & $-1.00-\leqslant 0.00$ & $0.01-\leqslant 1.00$ & $1.01 \mathrm{er}$ & \\
\hline Lndividuele praxis & 19.6 & 28.1 & 25.1 & 27.1 & 704 \\
\hline belde & 18.8 & 25.0 & 35.4 & $20 \cdot 8$ & 48 \\
\hline groepspraxis & $24 \cdot 3$ & 28.0 & 26.6 & 21.1 & 890 \\
\hline Totaa 1 & $22 \cdot 1$ & 28.0 & $26 \cdot 2$ & 23.7 & 1642 \\
\hline
\end{tabular}

Informatieve rolcomponent en vookeurshouding inzake aard van de praxis. 
TabeI 24.

Sociaal-opvoedende rolcomponent en

evaluatie van het medisch team-werk.

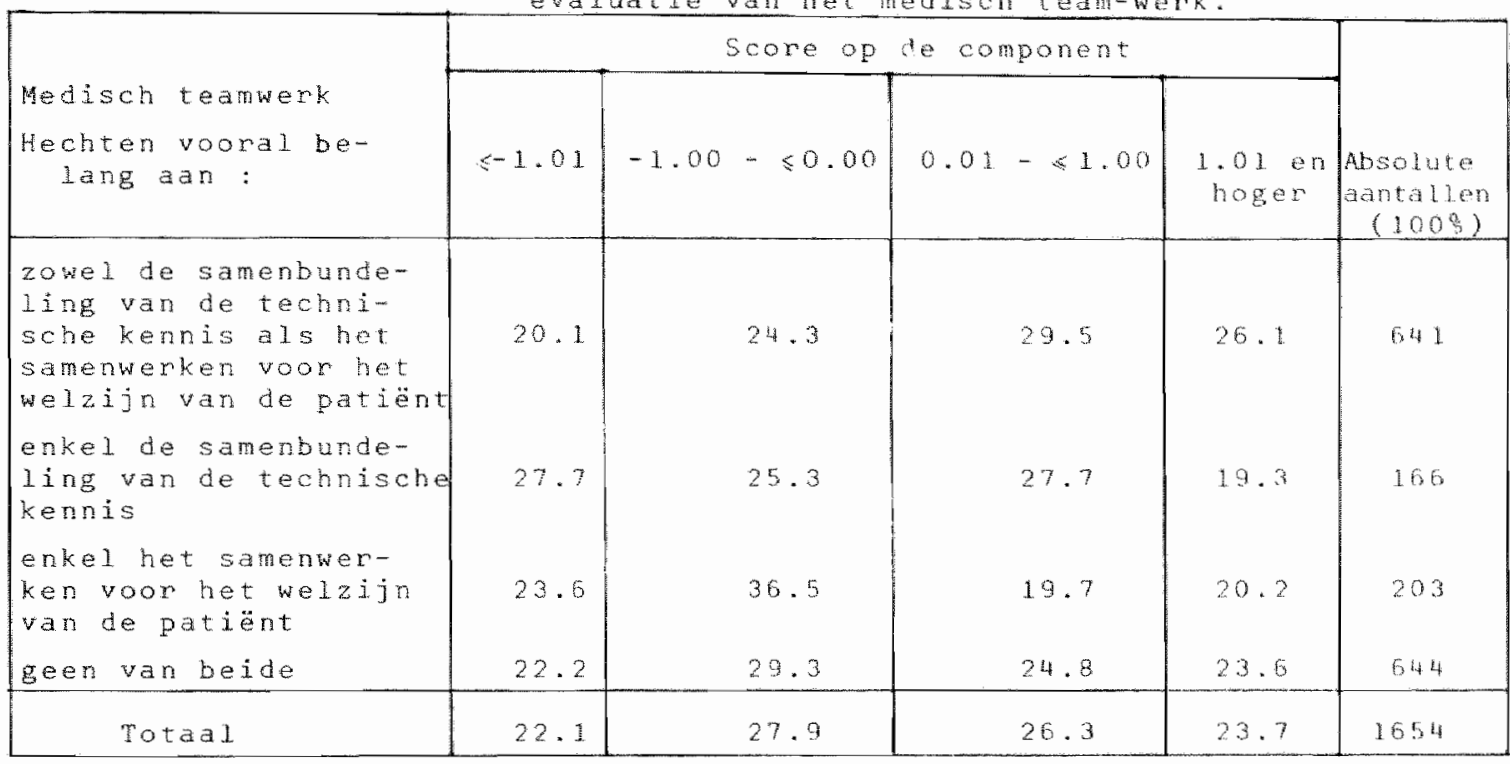

$x^{2}: 23 \cdot 24 ; \mathrm{dF} \cdot 9$

$\mathrm{P}: .006$

$Y: 0.057$

tabel 25.

Social-opvodende rolcomponent en ervaming met paramedische tussenkometen.

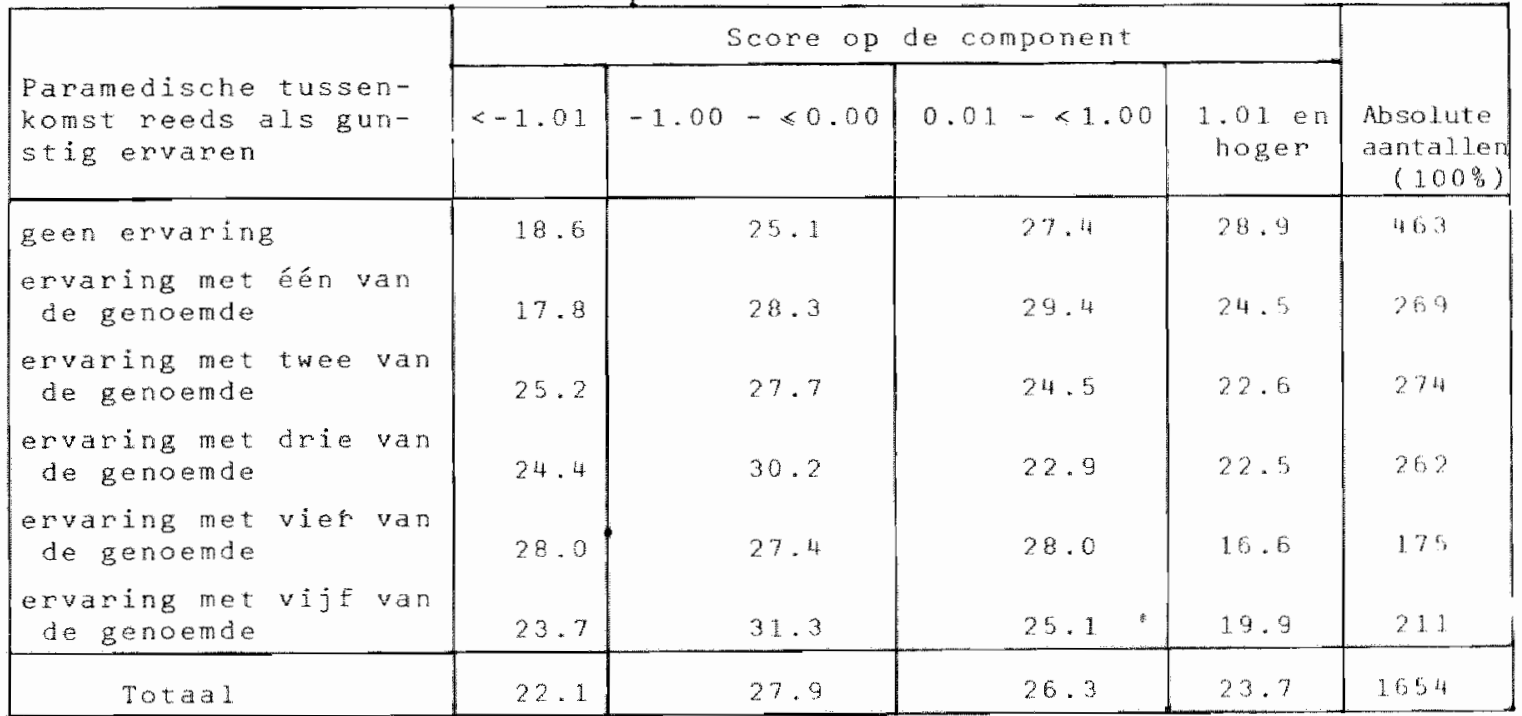
$x^{2}: 26 \cdot 10 ; d f \cdot 15$
$p: .038$
$\gamma: 0.108$
d: 0.08 


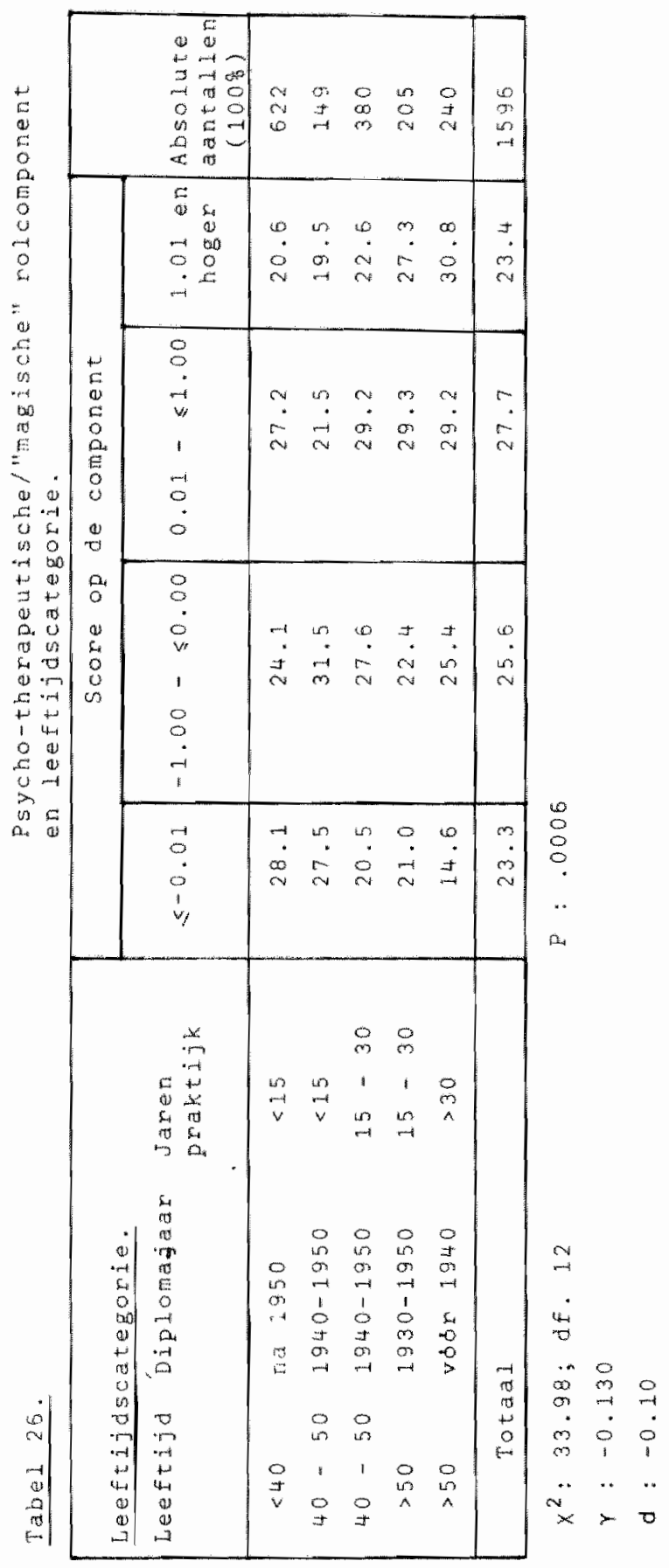


APPENDIX IV.

\begin{tabular}{|c|c|c|c|c|c|c|}
\hline Var. & $\begin{array}{c}\text { factor } \\
I\end{array}$ & $\begin{array}{c}f a c t o r \\
\text { II }\end{array}$ & $\begin{array}{l}\text { factor } \\
\text { III }\end{array}$ & $\begin{array}{c}\text { factor } \\
\text { IV }\end{array}$ & $\begin{array}{c}\text { factor } \\
\mathrm{V}\end{array}$ & $\begin{array}{r}h^{2} \\
\text { (comunal } i- \\
\text { teiten }) \\
\end{array}$ \\
\hline 132 & 45 & 07 & -04 & 01 & $0 ?$ & 21 \\
\hline 133 & -47 & -26 & 31 & 06 & -05 & 39 \\
\hline 137 & -34 & -21 & -10 & 14 & -11 & 20 \\
\hline 162 & -63 & 05 & 04 & -11 & 26 & 48 \\
\hline 165 & 68 & -05 & 05 & -03 & -03 & 47 \\
\hline 166 & -74 & 01 & 01 & -03 & -02 & 54 \\
\hline 173 & -49 & -20 & 07 & 24 & 10 & 35 \\
\hline 240 & -55 & 04 & 01 & -17 & -03 & 34 \\
\hline 241 & -36 & 02 & 08 & -08 & -02 & 14 \\
\hline 154 & 36 & 15 & 07 & -39 & 07 & 31 \\
\hline 126 & 17 & 03 & 19 & 33 & 16 & 20 \\
\hline 143 & -07 & 12 & -02 & 55 & 14 & 33 \\
\hline 144 & 31 & 21 & -03 & 44 & -02 & 33 \\
\hline 151 & -01 & 18 & 18 & 60 & -06 & 43 \\
\hline 152 & 07 & 05 & 13 & 45 & 11 & 24 \\
\hline 161 & -02 & -0 & -07 & 32 & -18 & 14 \\
\hline 163 & 13 & 0 & 11 & 56 & 01 & 34 \\
\hline 150 & -05 & 0 & 05 & 49 & -32 & 35 \\
\hline 153 & -09 & 05 & 28 & 36 & 36 & 35 \\
\hline 124 & -16 & -20 & -29 & -16 & 46 & 39 \\
\hline 155 & -16 & -11 & -15 & 07 & -53 & 34 \\
\hline 156 & 05 & -11 & -04 & 20 & -38 & 20 \\
\hline 157 & 05 & 0 & -18 & -09 & -44 & 23 \\
\hline 158 & $0 ?$ & -07 & -04 & -11 & -41 & 19 \\
\hline 123 & 06 & -23 & -40 & 06 & 51 & 47 \\
\hline 122 & -14 & -17 & 54 & 12 & -06 & 36 \\
\hline 125 & -03 & -11 & 39 & 07 & 16 & 20 \\
\hline 128 & -14 & 14 & 50 & -04 & -14 & 31 \\
\hline 129 & -15 & -05 & 56 & 17 & 0 & 37 \\
\hline
\end{tabular}




\begin{tabular}{|c|c|c|c|c|c|c|}
\hline var. & $\begin{array}{c}\text { factor } \\
I\end{array}$ & $\begin{array}{c}\text { factor } \\
\text { II }\end{array}$ & $\begin{array}{l}\text { factor } \\
\text { III }\end{array}$ & $\begin{array}{c}\text { factor } \\
\text { Iy }\end{array}$ & $\underset{V}{f a c t o r}$ & $\begin{array}{c}h^{2} \\
\text { (communati- } \\
\text { teiten) }\end{array}$ \\
\hline 135 & 18 & 02 & 53 & 12 & -02 & 33 \\
\hline 136 & -03 & 04 & 47 & 0 & 17 & 24 \\
\hline 145 & 0 & 42 & 46 & -10 & 18 & 43 \\
\hline 147 & 04 & 44 & 44 & -02 & 09 & 40 \\
\hline 111 & 11 & 39 & 02 & -15 & -18 & 22 \\
\hline 127 & 01 & -36 & 25 & -14 & 07 & 22 \\
\hline 139 & -28 & -38 & -06 & 06 & -27 & 30 \\
\hline 140 & -30 & -36 & 09 & -24 & -12 & 30 \\
\hline 141 & -06 & -61 & 08 & -14 & 11 & 41 \\
\hline 142 & -09 & 55 & 03 & -08 & -15 & 34 \\
\hline 146 & -09 & 45 & 23 & 14 & 10 & 29 \\
\hline 148 & 06 & 45 & 30 & 21 & 08 & 35 \\
\hline 159 & -07 & -54 & 06 & -15 & -23 & 38 \\
\hline 160 & -12 & -47 & 09 & -06 & -24 & 30 \\
\hline 134 & -28 & -27 & -11 & 25 & -06 & 22 \\
\hline 164 & -19 & 01 & 10 & 19 & -20 & 12 \\
\hline 214 & 17 & 16 & -07 & 09 & -01 & 07 \\
\hline $\begin{array}{l}\% \text { van } \\
\text { verklaar- } \\
\text { de va- } \\
\text { riantie }\end{array}$ & 7.46 & 6.70 & 6.09 & 5.91 & 4.61 & $30.77 \%$ \\
\hline $\begin{array}{l}\% \text { van } \\
\text { tot. va- } \\
\text { riantie }\end{array}$ & 24.22 & 21.75 & 12.77 & 19.21 & 14.97 & $99.99 \%$ \\
\hline
\end{tabular}


$A P P . V .1$.

STAPSGEWIJZE MEERVOUdIGE REGRESSIE

(verklaarde variantie)

Ie verklaren variabele.

1. Veel/weinig randmedische informatie als routine

$$
\begin{aligned}
& \text { Verklarende } \\
& \text { variabele }
\end{aligned}
$$

Specialisme

Ecol.milieu

Leeftijd

Praxisvorm
Mult.corr. coëff.
0.175
0.181
0.184
0.186

Percentage verkl.variantie

$$
\begin{gathered}
3.1 \\
(0.2) \\
(0.1) \\
(0.1) \\
\hline 3.5
\end{gathered}
$$

Mult.corr. coëff.
0.300
0.358
0.361
0.362
0.363

3. Verantwoordelijkheid van de huisarts blijft of gaat tamen door toenemende specialisatie

$$
\begin{aligned}
& \text { Verklarende } \\
& \text { variabele }
\end{aligned}
$$$$
\text { Specialisme }
$$$$
\text { Leeftijd }
$$

$$
\text { Mult.corr. }
$$
coëff.

0.159

0.205
Percentage verkl.variantie

$$
\begin{aligned}
& 9.0 \\
& 3.8 \\
& (0.2) \\
& (0.1) \\
& (0.1) \\
& \hline 13.2
\end{aligned}
$$

$$
\begin{gathered}
\text { Percentage } \\
\text { verkl. variantie } \\
\frac{2.5}{1.7} \\
\frac{4.2}{4}
\end{gathered}
$$

4. Bijzonderste taak van de arts is helpen/genezen

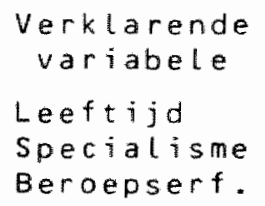

Mult.corr. coëf $f$.

0.159

0.196

0.199
Percentage verkl.variantie

$$
\begin{gathered}
2.5 \\
1.3 \\
(0.1)
\end{gathered}
$$


5. Zeer duidelijke/niet zeer duidelijke of geen zelfevaluatie in informatieve rolcomponent

$$
\begin{aligned}
& \text { Verklarende } \\
& \text { variabele }
\end{aligned}
$$

Spectalisme

Leeftijd

Praxisvorm

Ecol.milieu

$$
\begin{gathered}
\text { Mult. corr. } \\
\text { coëff. }
\end{gathered}
$$

0.150

0.187

0.197

0.206

Mult. corr. coëff.

Verklarende

variabele

Leeftijd

Specialisme

Beroepser $f$.

Ecol.milieu
0.220

0.256

0.261

0.263
Percentage verkl.variantie

$$
\begin{aligned}
& 2.3 \\
& 1.2 \\
& 0.4 \\
& 0.3 \\
& \hline 4.2
\end{aligned}
$$

$$
\begin{gathered}
\text { Percentage } \\
\text { verkl.variantie } \\
4.9 \\
1.7 \\
(0.3) \\
(0.1) \\
\hline 7.0
\end{gathered}
$$

7. Geen/wel gunstige ervaring met paramedici

$$
\begin{aligned}
& \text { Verklarende } \\
& \text { variabele } \\
& \text { specialisme } \\
& \text { Beroepserf } \\
& \text { Praxisvorm }
\end{aligned}
$$

Mult.corr. coëff.
0.253
0.258
0.259

Percentage verkl.variantie

$$
\begin{gathered}
6.4 \\
(0.2) \\
(0.1) \\
\hline 6.7
\end{gathered}
$$

8. In academische opleiding alg. geneeskunde accentueren of specialisatie. In praxis zelf psycho-soc. context betrekken of niet belangrijk/ geen $t$ ijd

$$
\begin{aligned}
& \text { verklarende } \\
& \text { variabele }
\end{aligned}
$$

Specialisme Leeftijd Beroepserf. Praxisvorm
Mult.corr. coëff.

0.188

0.222

0.226

0.227
Percentage verkl.variantie

$$
\begin{gathered}
3.5 \\
1.4 \\
(0.2) \\
(0.1)
\end{gathered}
$$


APPENDIX V.2

De standaardscores in de hiernavolgende tabellen werden berekend op de leeftijdsklassen per specialisme en op het total per specialisme. 
APPENDIX $V .2 .1$

Gemiddelde score door de onderscheiden specialisten behald op de statement dat in de praxis VEEL randmedische als routinearngelegenheid moet worden gezien.

\begin{tabular}{|c|c|c|}
\hline Specialisme & Gemiddelde score & Rang \\
\hline Neuropsychiaters & +2.277 & 1 \\
\hline Kinderartsen & +1.584 & 2 \\
\hline Klinische biologen & +0.891 & 3 \\
\hline Huisartsen & +0.198 & 4 \\
\hline $\begin{array}{l}\text { Internistentgastro- } \\
\text { enterologen }\end{array}$ & +0.099 & 5 \\
\hline Röntgenspecialisten & -0.099 & 6 \\
\hline Cardiologen+longartsen & -0.198 & 7 \\
\hline Anesthesisten & -0.396 & 8 \\
\hline Gynaecologen & -0.495 & 9 \\
\hline Chirurgentorthopedisten & -0.693 & 10 \\
\hline Mondartsen & -0.693 & 11 \\
\hline Dermatoven.+turologen & -0.792 & 12 \\
\hline $\begin{array}{l}\text { Fysiother. +rrth. +reumato- } \\
\text { logen }\end{array}$ & -0.990 & 13 \\
\hline $\begin{array}{l}\text { Keel-, neus-, oorspec.t } \\
\text { oogartsen }\end{array}$ & -1.584 & 14 \\
\hline
\end{tabular}


APPENDIX V.?.2. Gemiddelde score door de onderscheiden specialisten, ingedeetd naar leeftijdscategorie, behald op de statement: Ondanks het toenemend aantal specialisten, blijft de verantwoordelijkheid van de huisarts over een langere termijn bestaan.

\begin{tabular}{|c|c|c|c|}
\hline Specialisme & Leeftijd & $\begin{array}{l}\text { Gemiddelde } \\
\text { score }\end{array}$ & Rang \\
\hline Mondartsen & $(J)$ & +2.763 & 1 \\
\hline KLinische biologen & (s) & +1.513 & 2 \\
\hline Huisartsen & $(J)$ & +1.447 & 3 \\
\hline Neuropsychiaters & $(J)$ & +1.052 & 4 \\
\hline Klinische biologen & $(0)$ & +0.986 & 5 \\
\hline Röntgenspecialisten & $(J)$ & +0.657 & 6 \\
\hline Neuropsychiaters & $(0)$ & $+0.59 ?$ & 7 \\
\hline Keel-neus-oor,oog. & $(J)$ & +0.460 & 3 \\
\hline Anesthesisten & $(0)$ & $+0.3 ? 8$ & 9 \\
\hline Cardiol. , Longartsen & $(0)$ & +0.197 & 10 \\
\hline Huisartsen & $(0)$ & +0.131 & 11 \\
\hline Röntgenspecialisten & $(0)$ & +0.131 & 12 \\
\hline Fys., rrth., reumat. & $(J)$ & 0.000 & 13 \\
\hline Dermatoven, ,urolog. & $(J)$ & -0.065 & 14 \\
\hline Intern. gastro-ent. & $(J)$ & -0.131 & 15 \\
\hline Cardiol. , longartsen & $(J)$ & -1.131 & 16 \\
\hline Chirurg.,orthoped. & (d) & -0.263 & 17 \\
\hline Kinderartsen & $(J)$ & -0.263 & 18 \\
\hline Gytiaecologen & $(J)$ & -0.263 & 19 \\
\hline Intern.,gastro-ent. & $(0)$ & -0.328 & 20 \\
\hline Chirurg.,orthoped. & $(0)$ & -0.394 & 21 \\
\hline Fys., rrth., reumat. & $(0)$ & -0.460 & 22 \\
\hline Mondartsen & $(0)$ & -0.657 & 23 \\
\hline Dermatoven. ,urolog. & $(0)$ & -0.657 & $\geqslant 4$ \\
\hline Kinderartsen & $(0)$ & -0.789 & 25 \\
\hline Gynaecologen & $(0)$ & -0.921 & 26 \\
\hline Keel-neus-oor, oog. & $(0)$ & $-1.05 ?$ & 27 \\
\hline Anesthesisten & ( J) & -2.960 & 28 \\
\hline
\end{tabular}


APPENDIX V.2.3. Gemiddelde score behald door de onderscheiden specialisten, ingedeeld naar leeftijdscategorie op de statement : Helpen is de belangrijkste opdracht van de arts.

\begin{tabular}{|c|c|c|c|}
\hline Specialisme & Leeftijd & $\begin{array}{c}\text { Gemiddelde } \\
\text { score }\end{array}$ & Rang \\
\hline Anesthesisten & $(J)$ & +3.926 & 1 \\
\hline Kinderartsen & (J) & +1.472 & $?$ \\
\hline Huisartsen & (J) & +0.736 & 3 \\
\hline Neuropsychiaters & (J) & +0.674 & 4 \\
\hline Klin.biologen & $(0)$ & +0.490 & 5 \\
\hline Mondartsen & $(J)$ & +0.368 & 6 \\
\hline Intern.,gastro-ent. & $(J)$ & +0.245 & 7 \\
\hline Gynaecologen & $(\mathrm{J})$ & +0.245 & 8 \\
\hline Gynaecologen & $(0)$ & +0.245 & 9 \\
\hline Fys.,rrth., reumat. & $(J)$ & +0.184 & 10 \\
\hline Cardiol. longartsen & $(0)$ & $+0.12 ?$ & 11 \\
\hline Röntgenspecialisten & $(J)$ & +0.122 & 12 \\
\hline Anesthesisten & (o) & 0.000 & 13 \\
\hline KLin.biologen & $(J)$ & 0.000 & 14 \\
\hline Keel-neus-oor,oog. & (J) & -0.061 & 15 \\
\hline Chirurg., or thoped. & $(d)$ & -0.184 & 16 \\
\hline Keel-neus-oor,oog. & $\cos$ & -0.184 & 17 \\
\hline Röntgemspecialisten & $\cos$ & -0.245 & 18 \\
\hline Cardiol. Llongartsen & $(J)$ & -0.368 & 19 \\
\hline Huisartsen & $(0)$ & -0.368 & 20 \\
\hline Fys., rrth, reumat. & $(0)$ & -0.490 & 21 \\
\hline Intern.,gastro-ent. & $(0)$ & -0.674 & 22 \\
\hline Neuropsychiaters & $(0)$ & -0.674 & 23 \\
\hline Chirurg.,orthoped. & $(0)$ & -0.981 & 24 \\
\hline Dermatoven., urolog. & $(0)$ & -1.042 & 25 \\
\hline Dermatoven , urolog. & $(d)$ & -1.165 & 26 \\
\hline Mondartsen & $(0)$ & -1.349 & 27 \\
\hline Kinderartsen & $(0)$ & -1.411 & $\geq 8$ \\
\hline
\end{tabular}


APPENDIX V.2.4. Femiddelde score behald door de onderscheiden specialisten, ingedeeld nar leeftijdscategorie op de zelfevaluatie in de informatieve rolcomponent.

\begin{tabular}{|c|c|c|c|}
\hline Specialisme & Leeftijd & $\begin{array}{c}\text { Semiddelde } \\
\text { score }\end{array}$ & Rang \\
\hline Cardiol. Llongartsen & $(0)$ & +1.456 & 1 \\
\hline Klin.biologen & $(J)$ & +1.359 & 2 \\
\hline Neuropsychiaters & $(0)$ & +1.165 & 3 \\
\hline Kinderartsen & $(0)$ & +1.165 & 4 \\
\hline KLin.biologen & $(0)$ & +1.067 & 5 \\
\hline Mondartsen & (J) & +0.970 & 6 \\
\hline Gynaecologen & $(\mathrm{d})$ & +0.776 & 7 \\
\hline Cardiol., Longartsen & (J) & $+0.58 ?$ & 8 \\
\hline Gynaecologen & $(0)$ & $+0.58 ?$ & 9 \\
\hline Keel-neus-oor,oog. & (J) & +0.582 & 10 \\
\hline Anesthesisten & $(0)$ & +0.485 & 11 \\
\hline Chirurg.,orthoped. & $(0)$ & +0.485 & 12 \\
\hline Dermatoven., urolog. & $(\sqrt{ })$ & +0.388 & 13 \\
\hline Intern.,gastro-ent. & $(0)$ & +0.291 & 14 \\
\hline Chirurg., or thoped. & $(J)$ & +0.194 & 15 \\
\hline Mondartsen & $(0)$ & 0.000 & 16 \\
\hline Dermatoven., urolog. & $(0)$ & -0.097 & 17 \\
\hline Huisartsen & $(0)$ & -0.097 & 18 \\
\hline Keet-neus-oor, oog & $(0)$ & -0.194 & 19 \\
\hline Fys., rrth. , reumat. & $(J)$ & -0.194 & 20 \\
\hline Röntgenspecialisten & $(0)$ & -0.873 & 21 \\
\hline Neuropsychiaters & $(\mathrm{J})$ & -1.067 & 22 \\
\hline Kinderartsen & $(\mathrm{J})$ & -1.067 & 23 \\
\hline Röntgenspecialisten & (J) & -1.067 & 24 \\
\hline Huisartsen & (d) & -1.067 & 25 \\
\hline Intern. gastro-ent. & $(J)$ & $-1.26 ?$ & 26 \\
\hline Fys.,rrth., reumat. & $(0)$ & -1.456 & 27 \\
\hline Anesthesisten & (J) & -2.815 & 28 \\
\hline
\end{tabular}


APPENDIX V.2.5. Gemiddelde score behaald door de onderscheiden specialisten, ingedeeld naar leeftijdscategorie, op de evaluatie van de genoten academische opleiding. - De opleiding is NIET adequat.

\begin{tabular}{|c|c|c|c|}
\hline Specialisme & Leeftijd & $\begin{array}{c}\text { Geniddelde } \\
\text { score }\end{array}$ & Rang \\
\hline Anesthesisten & (J) & +1.911 & 1 \\
\hline KLin.biologen & $(\mathrm{J})$ & +1.544 & 2 \\
\hline Kinderartsen & $(J)$ & +1.544 & 3 \\
\hline Fys.,rrth., reumat. & $(J)$ & +1.176 & 4 \\
\hline Röntgenspecialisten & $(\mathrm{J})$ & +1.176 & 5 \\
\hline Mondartsen & $(J)$ & +1.029 & 6 \\
\hline Huisartsen & $(J)$ & +0.955 & 7 \\
\hline Neuropsychiaters & $(J)$ & +0.735 & 8 \\
\hline Chirurg.,orthoped. & $(J)$ & +0.514 & 9 \\
\hline Dermatoven., urologen & $(J)$ & +0.514 & 10 \\
\hline Intern.. gastro-ent. & $(\sqrt{ })$ & $+0.36 ?$ & 11 \\
\hline Keel-neus-oor,oog & ( J) & +0.367 & $1 ?$ \\
\hline Huisartsen & $(0)$ & +0.147 & 13 \\
\hline Gynaecologen & $(J)$ & 0.000 & 14 \\
\hline Cardiol., longartsen & (J) & 0.000 & 15 \\
\hline Fys., rrth., reumat. & $(0)$ & -0.073 & 16 \\
\hline Mondartsen & $(0)$ & -0.073 & 17 \\
\hline Röntgenspecialisten & $(0)$ & -0.294 & 18 \\
\hline Anesthesisten & $(0)$ & -0.441 & 19 \\
\hline Dermatoven., urologen & $(0)$ & -0.661 & 20 \\
\hline Chirurg., orthoped. & $(0)$ & -0.661 & 21 \\
\hline Kinderartsen & $(0)$ & -0.735 & $2 ?$ \\
\hline Cardiol., longartsen & $(0)$ & -1.176 & 23 \\
\hline Neuropsychiaters & $(0)$ & -1.250 & 24 \\
\hline Intern. gastro-ent. & $(0)$ & -1.323 & 25 \\
\hline Keel-neus-oor,oog. & $(0)$ & -1.387 & 26 \\
\hline$k$ Lin.biologen & $(0)$ & -1.617 & 27 \\
\hline Gynaecologen & $(0)$ & $-1.61 ?$ & 28 \\
\hline
\end{tabular}


APPENDIX V.2.6. Gemiddelde score behald door de onderscheiden specialismen op de variabele : Gunstige ervaring met het optreden in eigen praxis van paramedische hulpkrachten.

\begin{tabular}{|l|c|c|}
\hline Specialisme & $\begin{array}{c}\text { Gemiddelde } \\
\text { score }\end{array}$ & Rang \\
\hline Neuropsychiaters & +1.628 & 1 \\
Kinderartsen & +1.163 & 2 \\
Cardiol.,longartsen & +0.853 & 3 \\
Anesthesisten & +0.698 & 4 \\
Fys.,rrth.,reumat. & +0.465 & 5 \\
Gynaecologen & +0.388 & 6 \\
Chirurg.,orthoped. & +0.233 & 7 \\
Huisartsen & +0.233 & 8 \\
Intern.,gastro-ent. & +0.078 & 10 \\
Klin.biologen & -0.543 & 11 \\
Dermatoven., urologen & -1.000 & 12 \\
Mondartsen & -1.163 & 13 \\
Keel-neus-oor,oog. & -1.550 & 14 \\
Röntgenspecialisten & -1.783 & \\
\hline
\end{tabular}


APPENOIX V.2.7. Gemiddelde score behald door de onderscheiden specialisten, ingedeeld naar leeftijdscategorie op de statement : In de academische opleiding moet het accent op de algemeen medische vorming worden gelegd en in de praxis zelf moet de psycho-saciale context worden betrokken.

\begin{tabular}{|c|c|c|c|}
\hline Specialisme & Leeftijd & $\begin{array}{l}\text { Gemiddelde } \\
\text { score }\end{array}$ & Rang \\
\hline Fys., rrth., reumat. & $(J)$ & +1.612 & 1 \\
\hline Neuropsychiaters & $(\mathrm{J})$ & +1.290 & 2 \\
\hline Huisartsen & (J) & +1.048 & 3 \\
\hline Mondartsen & $(J)$ & +0.967 & 4 \\
\hline Cardiol., longartsen & (J) & +0.967 & 5 \\
\hline Röntgenspecialisten & $(J)$ & +0.887 & 6 \\
\hline Cardiol., longartsen & $(0)$ & +0.806 & 7 \\
\hline Kinderartsen & $(0)$ & +0.645 & 8 \\
\hline Kinderartsen & $(J)$ & +0.645 & 9 \\
\hline Gynaecologen & (J) & +0.564 & 10 \\
\hline Intern, gastro-ent. & $(J)$ & +0.403 & 11 \\
\hline Neuropsychiaters & $(0)$ & +0.322 & 12 \\
\hline Intern., gastro-ent. & $(J)$ & +0.161 & 13 \\
\hline Keel-neus-oor, oog. & $(\mathrm{J})$ & +0.080 & 14 \\
\hline Klin.biologen & $(0)$ & +0.080 & 15 \\
\hline Chirurg. ortoped. & $(J)$ & -0.080 & 16 \\
\hline Klin.biologen & $(J)$ & -0.161 & 17 \\
\hline Dermatoven., urologen & $(0)$ & -0.322 & 18 \\
\hline Fys.,rrth., reumat. & $(0)$ & -0.403 & 19 \\
\hline Gynaecologen & $(0)$ & -0.483 & 20 \\
\hline Dermatoven., urologen & (d) & -0.483 & 21 \\
\hline Huisartsen & $(0)$ & -0.564 & 22 \\
\hline Röntgenspecialisten & $(0)$ & -0.564 & 23 \\
\hline Keel-neus-oor,oog. & $(0)$ & -0.887 & $? 4$ \\
\hline Mondartsen & $(0)$ & -1.209 & 25 \\
\hline chirurg., orthoped. & $(0)$ & -1.290 & 26 \\
\hline Anesthesisten & $(0)$ & -1.774 & 27 \\
\hline Anesthesisten & $(J)$ & -3.064 & 28 \\
\hline
\end{tabular}


APPENDIX VI.1. LIJST DER AFHANKELIJKE VARIABELEN, BETROKKEN IN DE MULTIDIMENSIONELE SCHAALANALYSE.

Var.nr. Onschrijuing van de antwoordcategorie ên

1. a - beschouwen weinig (d.i. vijf en minder) randmedische gegevens in de praxis als routineaangelegenheid

b - beschouwen veel (d.i. zes tot twalf) randmedische gegevens als routineaangelegenheid

2. a - inwinnen van randmedische informatie is de taak van paramedic i

b - idem, mar taak van de arts zelf

3. a - in medisch teamwerk is gedeelde verantwoordelijkheid een zeer betangrijk element

b - gedeelde verantwoordelijkheid is onbelangrijk

4. a - randmedische informatie inwinnen moet routinezak zijn

b - randmedische informatie inwinnen enkel in specifieke gevallen

5. a - voorkeur voor individuele praxis

b - voorkeur voor groepspraxis

6. a - door het toenemend antal specialisten neemt de verantwoordelijkheid van de huisarts over een langere termijn af

b - die verantwoordelijkheid blijft

7. a - genezen is de belangrijkste taak van de arts

b - niet akkoord (... helpen)

8. a - evalueren zichzelt als zeer duidelijk preventief ingesteld

b - evalueren zichzelf niet zeer duidelijk of zwak op het preventief vlak

9.

a - evalueren zichzelf zeer duidelijk in de sociaalintegratieve rolcomponent

b - evalueren zichzelf niet zeer duidelijk of zwak in de social-integratieve rolcomponent

10. a - evalueren zichzelf zeer duidelijk in de informatieve rolcomponent

$b$ - evalueren zichzelf niet zeer duidelijk of $z$ wak in de informatieve rolcomponent 
11.

a - evalueren zichzelf zeer duidelijk in de sociaalopvoedende rolcomponent

b - evalueren zichzelf niet zeer duidelijk of zwak in de social-opvoedende rolcomponent

12.

a - evalueren zichzelf zeer duidelijk in de psychatherapeutische/ "magische" rolcomponent

b - evalueren zichzelt niet zeer duidelijk of zwak in de psycho-therapeutische/ "magische" rolcomponent

13. a - vinden de academische opleiding die zij genoten in alle opzichten adequat

b - vinden de acaderische opleiding die zij genoten niet in alle opzichten adequat

14.

a - hebben nog niet ervaren dat door het optreden van paramedici de behandeling van een patient werd vergemakkelijkt

b - hebben wél gunstige ervaring met paramedici

15 .

a - in medisch teamwerk staan zowel de samenbundeling van de technische kennis als de intense samenwerking voor het welzijn van de patient centraal

b - geen bijzondere appreciatie voor beide elementen in medisch teamwerk of zelfs geen appreciatie van medisch teamwerk

16.

a - in de opleiding tot arts moet het accent op de algemene geneeskunde worden gelegd en in de praxis zelf moet de arts de psycho-sociale context betrekken

b - niet akkoord daarmee of moeilijk een oordeel te vellen 
APPENDIX VI.2.

EINDCONFIGURATIE (MINISSA-I (N))

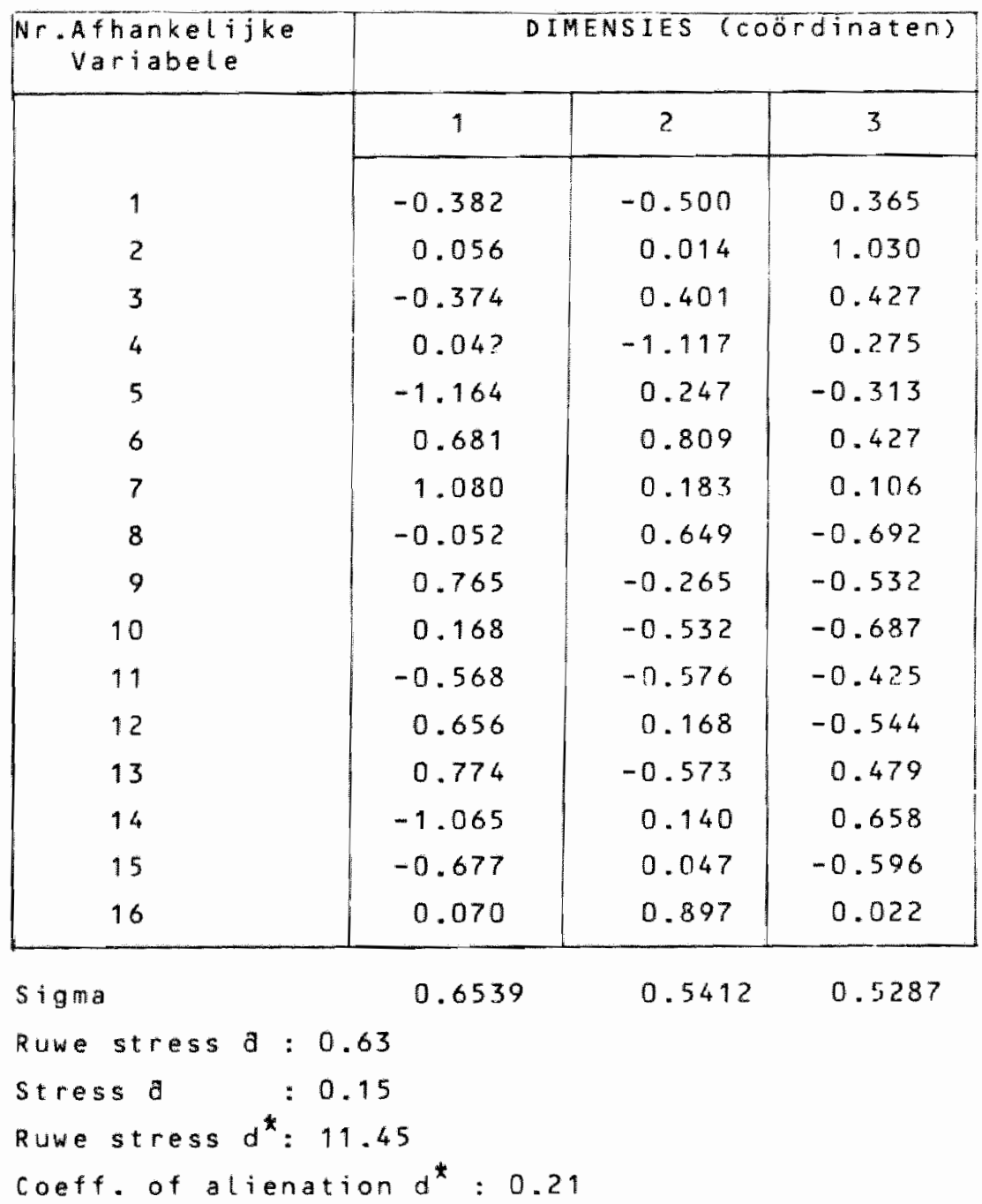


APPENDIX VI.3.

FREQUENTIEVERDELING VAN DE SCORES DER ARTSEN PER DIMENSIE

\begin{tabular}{r}
1 e \\
\hline sco \\
-7 \\
-6 \\
-5 \\
-4 \\
-3 \\
-2 \\
-1 \\
0 \\
1 \\
2 \\
3 \\
4 \\
5 \\
6 \\
7
\end{tabular}

\section{ZE OIMENSIE}

Proportie

0.3

Score Freauentie proportie

$-?$

4

3.5

1.1

8.3

10.7

13.6

16.3

21.4

11.5

5.7

4.9

1.7

0.7

0.1

0.1

\section{E DIMENSIE}

score

$-3$

Frequentie

3

$-4$

2

0.1

$-3$

25

1.8

$-2$

123

8.7

$-1$

140

9.9

0

518

36.6

1

259

18.3

2

228

16.1

3

104

7.4

4

15

1.1

.2

$-2$

35

$-1$

72

0

425

5.1

1

239

30.1

16.9

2

268

19.0

3

242

17.1

4

130

9.2 
APPENDIX VI.4.1.

1 e DIMENSIE (samenstelling)

(1)

Variabele.

Coördinaten

1. Voorkeur voor individuele praxis.

1.164

2. Belangrijkste taak van de arts is niet genezen, mar 'helpen'.

3. Gunstige ervaring met paramedische tussenkomsten in eigen praxis.

4. Duidelijke kritiek op de genoten academische opleiding.

0.774

5. Zeer duidelijke zelfevaluatie in de sosial-integratieve rolcomponent.

0.765

6. Ondanks toenemend aantal specialisten, blijft de verantwoordelijkheid over een Langere termijn van de huisarts bestaan.

7. Volledige wardering van medisch teamwerk.

8. Zeer duidelijke zelfevaluatie in de psycho-therapeut ische/ 'magische" rolcomponent.

9. Zeer duidelijke zelfevaluatie in de social-opvoedende rolcomponent.

10. Veel randmedische informatie inwinnen moet routineangelegenheid zijn.

11. Gedeelde verantwoordelijkheid in medisch teamwerk is belangrijk.

0.374

(1) De tekens bij de coördinaten werden weggelaten om de overzichtelijkheid te dienen. 
APPENDIX VI.4.2.

\section{DIMENSIE (samenstelling)}

Variabele.

Coördinaten

1. Randmedische informatie inwinnen moet routineaangelegenheid zijn.

2. In de opleiding moet het accent gelegd worden op een algemeen medische vorming en in de praxis zelf moet de psycho-sociale context van de ziekte worden betrokken.

3. Ondanks het toenemend a antal specialisten blijft de verantwoordelijkheid over een langere termijn van de huisarts bestaan.

0.809

4. Zeer duidelijke preventieve instelling.

0.649

5. Zeer duidelijke kritiek op de genoten academische opleiding.

0.573

6. Zeer duidelijke zelfevaluatie in de sociaal-opvoedende rolcomponent.

7. Zeer duidelijke zelfevaluatie in de informatieve rolcomponent.

8. Veel randmedische informatie inwinnen moet routineaangelegenheid zijn.

0.500

9. Gedeelde verantwoordelijkheid in medisch teamwerk is belangrijk.

0.401 
APPENDIX VI.4.3.

3e DIMENSIE (samenstelling)

Variabele.

Coördinaten

1. Randmedische informatie inwinnen is uitsluitend de taak van paramedici.

1.030

2. Zeer duidelijke preventieve instelling.

0.69 ?

3. Zeer duidelijke zelfevaluatie in de informatieve rolcomponent.

0.687

4. Gunstige ervaring met het optreden van paramedici in eigen praxis.

0.658

5. Volledige wardering van medisch teamwerk.

0.596

6. Zeer duidelijke zelfevaluatie in de psycho-therapeut ischel'magische' rolcomponent.

0.544

7. Zeer duidelijke zelfevaluatie in de social-integratieve rolcomponent.

0.532

8. Zeer duidelijke kritiek op de genoten academische opleiding.

0.479

9. Gedeelde verantwoordelijkheid in medisch teamwerk is belangrijk.

0.427

10. Ondanks het toenemend aantal specialisten blijft de verantwoordelijkheid over een langere termijn van de huisarts bestan.

0.427

11. Zeer duidelijke zelfevaluatie in de social-opvoedende rolcomponent.

0.425

12. Veel randmedische informatie inwinnen moet een routineaangelegenheid zijn.

0.365 
APPENDIX VI. 4.

Voor de berekening van de scores in de hiernavolgende tabellen werd gebruik gemakt van volgende formule:

$$
y_{j}=\sum_{i=1}^{k} \frac{\bar{x}_{i}-m_{i}}{\sigma_{i}} \times c_{i}
$$

warbij $k=$ a antal veranderlijken met coördinaten $\left(C_{i}\right)$ voor dimensie $j$ 
APPENDIX V1.4.4.

$$
\text { 1e DIMENSIE }
$$

Gemiddelde score en rang binnen de leeftijdscategorieën der onderscheiden specialismen.

\begin{tabular}{|c|c|c|c|c|}
\hline \multirow{3}{*}{ Specialisme } & \multicolumn{4}{|c|}{ LEEFTIJ D } \\
\hline & \multicolumn{2}{|c|}{$<40$ jar } & \multicolumn{2}{|c|}{$>40$ jaar } \\
\hline & score & Rang & score & Rang \\
\hline Anesthesisten & +16.65 & 1 & -0.81 & 8 \\
\hline Klin.biologen & -2.59 & 8 & -3.61 & 13 \\
\hline $\begin{array}{l}\text { Cardiologen }+ \\
\text { longartsen }\end{array}$ & -2.81 & 9 & -0.06 & 6 \\
\hline $\begin{array}{l}\text { Chirurgen }+ \\
\text { orthopedisten }\end{array}$ & -3.16 & 11 & -1.16 & 9 \\
\hline $\begin{array}{l}\text { Dermato-venerol. } \\
\text { urologen }\end{array}$ & -3.42 & 12 & -0.05 & 5 \\
\hline $\begin{array}{l}\text { Internisten }+ \\
\text { gastro-enterol. }\end{array}$ & -2.93 & 10 & -1.38 & 11 \\
\hline Gynaecologen & -2.00 & 7 & +3.27 & $?$ \\
\hline Neuropsychiaters & +1.50 & 4 & +4.21 & 1 \\
\hline $\begin{array}{l}\text { Keel-, neus-, oor- } \\
\text { specialisten + } \\
\text { oogartsen }\end{array}$ & -4.29 & 14 & +0.31 & 4 \\
\hline Kinderartsen & +4.21 & $?$ & +0.79 & 7 \\
\hline $\begin{array}{l}\text { Fystotherapeuten } \\
\text { rad.rad. therapeu- } \\
\text { tentreumatologen }\end{array}$ & -0.78 & 6 & -2.41 & 12 \\
\hline Röntgenspecialisten & -3.99 & 13 & -4.03 & 14 \\
\hline Mondartsen & +1.40 & 5 & -1.25 & 10 \\
\hline Huisartsen & +2.03 & 3 & +3.13 & 3 \\
\hline
\end{tabular}


APPENDIX VI.4.5.

1 e DIMENSIE

Leeftijdsuerschil binnen het specialisme (gemiddelde score en rang)

\begin{tabular}{|c|c|c|c|c|}
\hline \multirow{3}{*}{ SPECIALISME } & \multicolumn{4}{|c|}{ LEEFTIJD } \\
\hline & \multicolumn{2}{|c|}{$<40 \mathrm{jaar}$} & \multicolumn{2}{|c|}{$>40 \mathrm{jaar}$} \\
\hline & score & Rang & Score & Rang \\
\hline Anesthesisten & +7.422 & 1 & -7.422 & 2 \\
\hline Klin.biologen & -0.330 & 2 & +0.330 & 1 \\
\hline $\begin{array}{l}\text { Cardiologent } \\
\text { longartsen }\end{array}$ & +1.848 & 1 & $-1.848^{\circ}$ & 2 \\
\hline $\begin{array}{l}\text { Chirurgen t } \\
\text { orthopedisten }\end{array}$ & -1.645 & 2 & +1.645 & 1 \\
\hline $\begin{array}{l}\text { Dermato-venerol.* } \\
\text { urologen }\end{array}$ & -2.208 & 2 & +2.208 & 1 \\
\hline $\begin{array}{l}\text { Internisten } \\
\text { gastro-enterol. }\end{array}$ & -0.836 & 2 & +0.836 & 1 \\
\hline Gynaecologen & -2.736 & 2 & +2.736 & 1 \\
\hline Neuropsychiaters & +0.864 & 1 & -0.864 & 2 \\
\hline $\begin{array}{l}\text { Keel-, neus-,oor- } \\
\text { specialisten }+ \\
\text { oogartsen }\end{array}$ & -1.600 & 2 & +1.600 & 1 \\
\hline Kinderartsen & +2.596 & 1 & -2.596 & 2 \\
\hline $\begin{array}{l}\text { Fysiotherapeutent } \\
\text { rad.rad. Sherapeu- } \\
\text { tentreumatologen }\end{array}$ & +3.748 & 1 & -3.748 & 2 \\
\hline Röntgenspecialisten & -0.605 & 2 & +0.605 & 1 \\
\hline Mondartsen & +3.958 & 1 & -3.958 & 2 \\
\hline Huisartsen & -0.124 & 2 & +0.124 & 1 \\
\hline
\end{tabular}


APPENDIX VI. 4.6

2E DIMENSIE

Geniddelde score en rang binnen de leeftijdscategorieên der onderscheiden specialismen.

\begin{tabular}{|c|c|c|c|c|}
\hline \multirow{3}{*}{ SPECIALISME } & \multicolumn{4}{|c|}{ LEEFTIJD } \\
\hline & \multicolumn{2}{|c|}{$<40$ jaar } & \multicolumn{2}{|c|}{$>40$ jaar } \\
\hline & Score & Rang & Score & Rang \\
\hline Anesthesisten & +13.69 & 1 & +2.73 & 3 \\
\hline Klin.biologen & -0.27 & 3 & -1.48 & 12 \\
\hline $\begin{array}{l}\text { Cardiologen } \\
\text { longartsen }\end{array}$ & -3.92 & 12 & -3.38 & 14 \\
\hline $\begin{array}{l}\text { Chirurgen } t \\
\text { orthopedisten }\end{array}$ & -1.53 & 8 & +2.25 & 5 \\
\hline $\begin{array}{l}\text { Dermato-venerol. } \\
\text { urologen }\end{array}$ & -3.36 & 11 & -0.36 & 10 \\
\hline $\begin{array}{l}\text { Internisten } \\
\text { gastro-enterot. }\end{array}$ & -0.92 & 5 & -1.51 & 13 \\
\hline Gynaecologen & -1.17 & 6 & +0.63 & 8 \\
\hline Neuropsychiaters & -0.27 & 4 & +2.50 & 4 \\
\hline $\begin{array}{l}\text { Keel-, neus-, oor- } \\
\text { specialisten }+ \\
\text { oogartsen }\end{array}$ & -4.50 & 13 & +1.25 & 6 \\
\hline Kinderartsen & +0.99 & 2 & -1.42 & 11 \\
\hline $\begin{array}{l}\text { Fysiother apeutent } \\
\text { rad.rad.therapeut.+ } \\
\text { reumatologen }\end{array}$ & -1.76 & 10 & +2.97 & 2 \\
\hline Röntgenspeciatist. & -1.62 & 9 & +0.47 & 9 \\
\hline Mondartsen & -5.00 & 14 & +3.25 & 1 \\
\hline Huisartsen & -1.27 & 7 & +1.23 & 7 \\
\hline
\end{tabular}


APPENDIX VI.4.7.

2 e DIMENSIE

Leeftijdsverschil binnen het specialisme (gemiddelde score en rang)

\begin{tabular}{|c|c|c|c|c|}
\hline \multirow{3}{*}{ SPECIALISME } & \multicolumn{4}{|c|}{ LEEF T I JD } \\
\hline & \multicolumn{2}{|c|}{$<40$ jaar } & \multicolumn{2}{|c|}{$>40 \mathrm{jaar}$} \\
\hline & score & Rang & score & Rang \\
\hline Anesthesisten & +4.766 & 1 & -4.766 & 2 \\
\hline Klin.biologen & -0.151 & 2 & +0.151 & 1 \\
\hline $\begin{array}{l}\text { Cardiologen } \\
\text { longartsen }\end{array}$ & -1.083 & $?$ & +1.083 & 1 \\
\hline $\begin{array}{l}\text { Chirurgen t } \\
\text { orthopedisten }\end{array}$ & -2.033 & 2 & +2.033 & 1 \\
\hline $\begin{array}{l}\text { Dermato-venerol. } \\
\text { urologen }\end{array}$ & -3.449 & 2 & +3.449 & 1 \\
\hline $\begin{array}{l}\text { Internisten }+ \\
\text { gastro-enterol. }\end{array}$ & -1.384 & 2 & +1.384 & 1 \\
\hline Gynaecologen & -1.130 & 2 & +1.130 & 1 \\
\hline Neuropsychiaters & +0.533 & 1 & -0.533 & 2 \\
\hline $\begin{array}{l}\text { Keel-, neus-,oor- } \\
\text { specialisten }+ \\
\text { oogartsen }\end{array}$ & -1.883 & 2 & +1.883 & 1 \\
\hline Kinderartsen & +1.396 & 1 & -1.396 & 2 \\
\hline $\begin{array}{l}\text { Fysiotherapeutent } \\
\text { rad.rad.therapeu- } \\
\text { ten + reumatol. }\end{array}$ & -0.539 & 2 & +0.539 & 1 \\
\hline Röntgenspecial. & +0.343 & 1 & -0.343 & 2 \\
\hline Mondartsen & -1.539 & 2 & +1.539 & 1 \\
\hline Huisartsen & -0.201 & 2 & +0.201 & 1 \\
\hline
\end{tabular}


APPENDIX VI.4.8.

3 E DIMENSIE

Gemiddelde score en rang binnen de leeftijdscategorieèn der onderscheiden specialismen

\begin{tabular}{|c|c|c|c|c|}
\hline \multirow{3}{*}{ SPECIALISME } & \multicolumn{4}{|c|}{ LEEFTIJD } \\
\hline & \multicolumn{2}{|c|}{$<40$ jaar } & \multicolumn{2}{|c|}{$>40$ jar } \\
\hline & score & Rang & Score & Rang \\
\hline Anesthesisten & +15.18 & 1 & -1.21 & 9 \\
\hline Klin.biologen & -1.37 & 8 & -1.88 & 12 \\
\hline $\begin{array}{l}\text { Cardiologen } \\
\text { longartsen }\end{array}$ & -2.23 & 12 & -2.63 & 13 \\
\hline $\begin{array}{l}\text { Chirurgen } t \\
\text { orthopedisten }\end{array}$ & -1.90 & 10 & +2.67 & 2 \\
\hline $\begin{array}{l}\text { Dermato-venerol. } \\
\text { urologen }\end{array}$ & -1.00 & 6 & -4.53 & 14 \\
\hline $\begin{array}{l}\text { Internisten }+ \\
\text { gastro-enterol. }\end{array}$ & -1.24 & 7 & -1.58 & 10 \\
\hline Gynaecologen & -2.13 & 11 & +2.83 & 1 \\
\hline Neuropsychiaters & +1.26 & 2 & +0.90 & 5 \\
\hline $\begin{array}{l}\text { Keel-, neus-, oor- } \\
\text { specialisten t } \\
\text { oogartsen }\end{array}$ & -5.17 & 14 & -1.18 & 8 \\
\hline Kinderartsen & +0.48 & 4 & -1.67 & 11 \\
\hline $\begin{array}{l}\text { Fysiotherapeutent } \\
\text { rad.rad. the rapeu- } \\
\text { tentreumatologen }\end{array}$ & -0.31 & 5 & +2.47 & 3 \\
\hline Röntgenspecialist. & -2.27 & 13 & -0.58 & 7 \\
\hline Mondartsen & -1.84 & 9 & -0.46 & 6 \\
\hline Huisartsen & +0.56 & 3 & +1.59 & 4 \\
\hline
\end{tabular}


APPEWEIX VI.4.9.

3e D N

Leeftidsyerschil binnen het speciallswe

(gendodede score en rang)

\begin{tabular}{|c|c|c|c|c|}
\hline \multirow{3}{*}{ SPECIALISHE } & \multicolumn{4}{|c|}{ LEETIDD } \\
\hline & \multicolumn{2}{|c|}{$403 a r$} & \multicolumn{2}{|c|}{$>40$ ia } \\
\hline & score & Rang & score & tang \\
\hline Anesthesisten & +6.32 & 1 & -6.33 & 2 \\
\hline kin.biologen & -1.090 & 3 & +1.090 & 1 \\
\hline $\begin{array}{l}\text { cardiologen } \\
\text { longartsen }\end{array}$ & +1.614 & 1 & -1.614 & 2 \\
\hline $\begin{array}{l}\text { chrurgen } \\
\text { orthopedisten }\end{array}$ & -2.588 & 2 & +2.588 & 1 \\
\hline $\begin{array}{l}\text { Dernato-venerol.* } \\
\text { urologen }\end{array}$ & $-1 \times 788$ & 2 & +1.788 & 1 \\
\hline $\begin{array}{l}\text { internstent } \\
\text { gastro-enterol. }\end{array}$ & -0.938 & 2 & 40.938 & 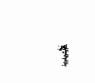 \\
\hline Gynaecologen & -3.539 & 2 & +3.539 & 1 \\
\hline Neuropsychiaters & +1.514 & 1 & -1.514 & 2 \\
\hline $\begin{array}{l}\text { Keel-, heus-,oor- } \\
\text { spectalistent } \\
\text { oogartsen }\end{array}$ & -3.734 & 1 & +3.734 & 1 \\
\hline Kinderartsen & +3.999 & 1 & -3.999 & 2 \\
\hline $\begin{array}{l}\text { Fysiotherapeutent } \\
\text { rad.rad. specialis- } \\
\text { tentreumatologen }\end{array}$ & +0.336 & 1 & -0.336 & 2 \\
\hline Röntgenspecialist. & -1.142 & 2 & +1.142 & 1 \\
\hline Mondartsen & +0.474 & 1 & -0.474 & 2 \\
\hline Huisartsen & +0.398 & 1 & -0.398 & 2 \\
\hline
\end{tabular}




\title{
VRAGEILIJST
}

\author{
HOOFDSTUK
}

DIT EEASTE HOOFDSTUK POOGT IN ALGEMENE TERMEN DE PERSOON VAN DE DOKTER TE OMSCHRIUVEN

(Antwoord zoveel mogelljk in termen van uw specialiteit)

Vr. 1 : Een a goede o geneesheer kan men kennen aan:

- De appreciatie van ziln diengten door de patienten

\begin{tabular}{|c|c|c|c|c|c|c|}
\hline $\begin{array}{l}\text { Volledig } \\
\text { akkoord }\end{array}$ & Akkoord & \pm Akkoord & $\begin{array}{l}\text { Moeilik to } \\
\text { oordelen }\end{array}$ & $\begin{array}{l}\text { Niet volledig } \\
\text { akkoord }\end{array}$ & $\begin{array}{c}\text { Niet } \\
\text { akkoord }\end{array}$ & $\begin{array}{l}\text { Absoluut } \\
\text { niet akkoord }\end{array}$ \\
\hline 1 & 2 & 3 & 4 & 5 & 6 & 7 \\
\hline
\end{tabular}

- De erkenning als goede geneesheer door ziln collega's

$\begin{array}{llllllllll}1 & 1 & 2 & 1 & 3 & 1 & 4 & 1 & 5 & 6\end{array}$

- De vertrouwellike omgang met patienten

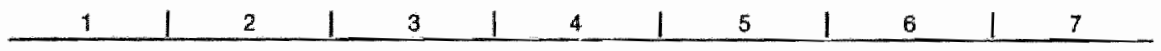

- De wetenschappelilke onderzokingen die hij doet en de publikaties die hij heelt

\begin{tabular}{|c|c|c|c|c|c|c|}
\hline 1 & 2 & 3 & 4 & 5 & 6 & 7 \\
\hline
\end{tabular}

- Zin medische kennis

$\begin{array}{llllllllll}1 & 1 & 2 & 1 & 3 & 1 & 4 & 1 & 5 & 6\end{array}$

Vr. 2 : De volgende laktoren ziln

Uiterst belangrijk... absoluut onbelangrijk voor het welslagen van de geneesheer in zin loopbaan:

- Dragen van dokterskledil

\begin{tabular}{|c|c|c|c|c|c|c|}
\hline $\begin{array}{c}\text { Ulterst } \\
\text { belangrijk }\end{array}$ & Betangrijk & - Balangrijk & $\begin{array}{l}\text { Moeilik te } \\
\text { oordoien }\end{array}$ & $\begin{array}{l}\text { Niet erg } \\
\text { belangrijk }\end{array}$ & Onbelangrijk & $\begin{array}{c}\text { Absoluut } \\
\text { onbelangrik }\end{array}$ \\
\hline 1 & 2 & 3 & 4 & 5 & 6 & 7 \\
\hline
\end{tabular}

- Vertrouwelitke omgang met de patienten

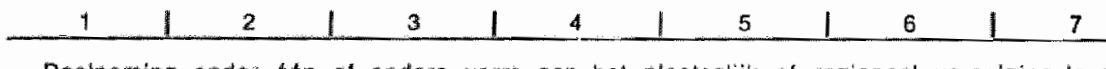

- Destneming onder eun of endero vorm an het platoelijk of regionaal verenigingsieven

\begin{tabular}{lllllllllll}
1 & 1 & 2 & & 3 & 4 & 5 & 1 & 6 & 7 \\
\hline
\end{tabular}

Conversatiozin

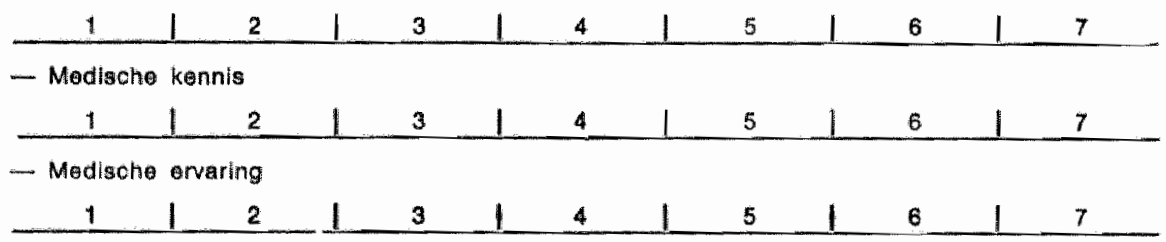

Vr. 3: De geneesheer beleaft het meest persoonlike voldoening aan het oplossen ven:

- Ean velatel envoudig zlaklegeval waarvoor de betrokken patient erkentelijk is.

\begin{tabular}{|c|c|c|c|c|c|c|}
\hline $\begin{array}{l}\text { Volledig } \\
\text { akkoord }\end{array}$ & Akkoord & \pm Akkoord & $\begin{array}{l}\text { Mooilik te } \\
\text { oordelen }\end{array}$ & $\begin{array}{l}\text { Niet volledig } \\
\text { akkoord }\end{array}$ & $\begin{array}{l}\text { Niet } \\
\text { akkoord }\end{array}$ & $\begin{array}{l}\text { Absoluut } \\
\text { riel akkooro }\end{array}$ \\
\hline
\end{tabular}
- Ean tamelik ingewikkeld zieklegewal warvoor de betrokken patient zijn erkentelijkheid niet

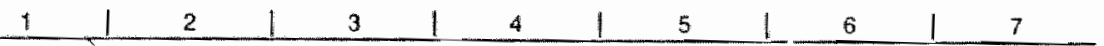


Vr. 4 : Weke waardering kent $U$ toe aan:

- Een dokter die bereid is nieuwe behandelingsmethodes loe te passen (bub. het amwenden van nieuwe geneesmididelen die op de farnaceutische markt verschinen

\begin{tabular}{|c|c|c|c|c|c|c|}
\hline $\begin{array}{l}\text { Ten volle } \\
\text { waardaerb. }\end{array}$ & $\begin{array}{c}\text { Waardeer- } \\
\text { baar }\end{array}$ & $\begin{array}{c} \pm \text { Waardear } \\
\text { baar }\end{array}$ & $\begin{array}{l}\text { Moelilik te } \\
\text { oordeten }\end{array}$ & $\begin{array}{l}\text { Niet voltedig } \\
\text { watrdeerb. }\end{array}$ & $\begin{array}{l}\text { Niet waar- } \\
\text { deerbaar }\end{array}$ & $\begin{array}{l}\text { Absoluut niet } \\
\text { waardeetb. }\end{array}$ \\
\hline 1 & 2 & 3 & 4 & 5 & 6 & 7 \\
\hline
\end{tabular}

- Een dokter die er zich eerst van overtuigt dat de behandelingsmethodes reeds voldoende door collega's werden beproetd

$\begin{array}{llllllll}1 & 1 & 2 & 1 & 3 & 1 & 4 & 1\end{array}$

\section{DE TAKEN VAN DE DOKIEA}

(Antwocrd zoveel mogelikk in termen van uw specialitent 1$)$

Vr. 1.: "De meest belangrijke laak van de praktiserende dokter is de patient af te helpen van zin ziekte of aandoening

\begin{tabular}{l}
$1 \quad 2 \quad$ \\
\hline
\end{tabular}

VI. 2: in zịn dagelijkse praktijk hoeft de geneeshear enige lijgd te voorzlen am met elke patient die hif ontwangt of bezoekt een tort gesprek te voeren dat niet noodzakelijk in onmoldellijk verband staat met de klachten van de pavent s.

$1 \quad 1 \quad 2 \quad 1 \quad 3 \quad 1 \quad 4 \quad-1 \quad 5 \quad 1 \quad 6 \quad 6 \quad 1 \quad 3$

Vr. 3 : "Ernstige familiale moeillkheden die noohtans van rechtswege geen tegemoetkoming voorzion zouden voor do dokter een voldoende reden moeten ziin om aan een "pateht " een medisch attest ter excuus at te leveren.

$\begin{array}{lllllllllll}1 & 1 & 2 & 1 & 3 & 4 & 4 & 5 & 6 & 1 & 6\end{array}$

Vr. 4: "In de medische praktik is het gebruikelijk zich tegamoekomend te tonen ten overstann van patienten die slochts bil wijze van uitzondering om een medisch voorschrift werzoeken om nist medische redenen ".

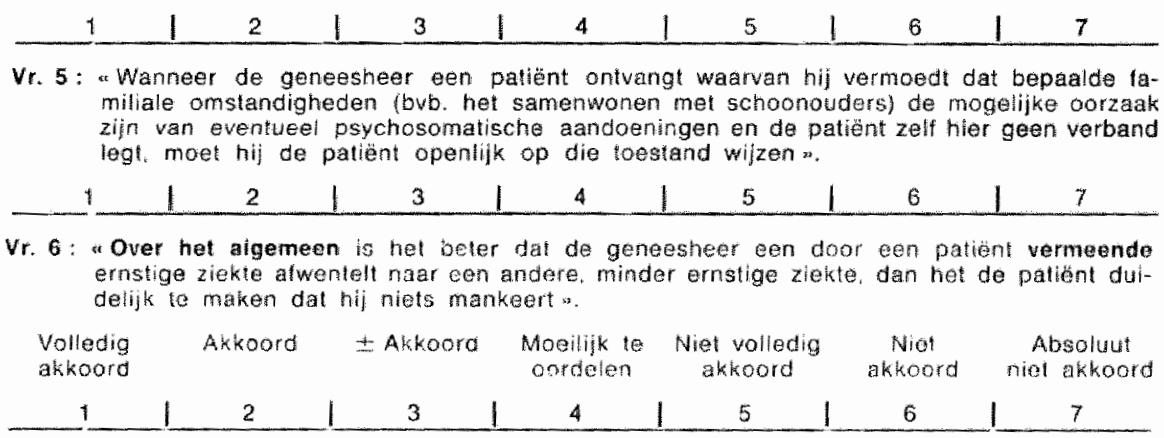

Vr. 7: "Wanteer een patient bewust simuleert zick te zijn, is hel eerder angewezen de pationt in te volgen. dan hem er rechtstreeks op te wijen dat hij niet ziek is

$\begin{array}{llllllllll}1 & 1 & 2 & 1 & 3 & 4 & 4 & 5 & 5 & \end{array}$

Vr. 8: voor een adequate behandeling var d a patient is tet wiferst belangrijk .. absoluut on. belangrijk. dat de genessheer de emolonale weerklank kent wan de ziekte yan do patent op diens gezin 2 .

$\begin{array}{llllllllll}1 & 1 & 2 & 1 & 3 & 1 & 4 & -1 & 5 & 1\end{array}$

V. 9: "Yoor het herstel van een patient is het uiferst belangrijk... absoluut onbelangrijk... dat de geneesheer het gezin van de patient betrekt in hel contact luesen hem on zin palient:

1
1 $\quad 2 \quad 1 \quad 3 \quad 1 \quad 4 \quad 4 \quad 1 \quad 5 \quad 1 \quad 6 \quad 1 \quad 7$




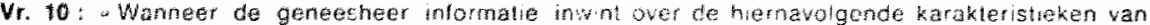
cen patent. hoett hil dit te doen

1. Als ben doel van routine-intormatie

2 als cen deel vatu de hotomatio die de doker enkel in spodifieke gevatten inwint Om uw oordeel te kenren te geven schrilt i of 2 naast ek van de hiernavolgende gegeveres:

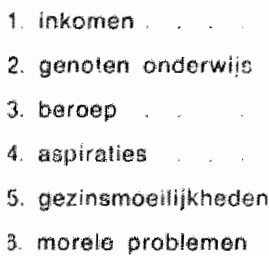

7. betrekkingen met vrienden

8. Unanciele mooilikheden

9. woonvoonvaarden

10. Whe tijo

1). diset

12. wroegere behandeling

HOOFOSTUK III

DE HUIDIGE MEDISCHE PRAKTIJK

(Antwoord zoveel mogelijk in termen van uw specialitell 1 )

Vr. 1; "De medische praktijk is tegenwoordig zo zwaar belask dak de geneesteer nauwelijks of geen tijd heet om met alke patient een gesprek te voeren dat geen verband houd met de zlekte van de pallënt

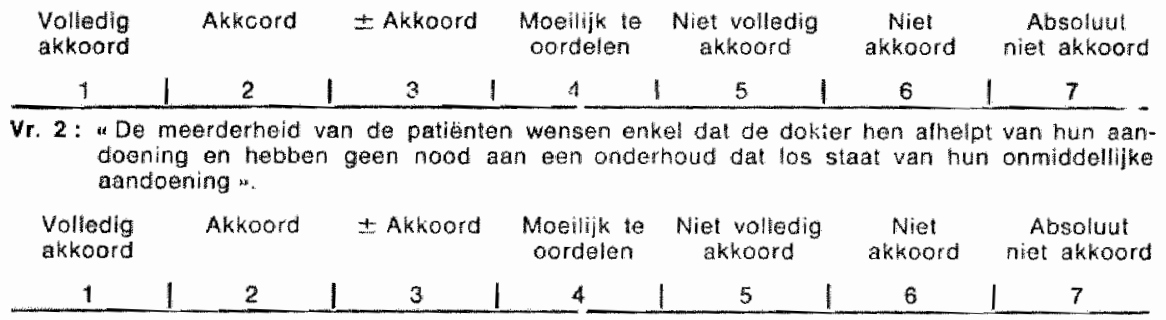

Vr. 3 : Arbeldedruk . en overwerkt * worden tegenwoordig bif de geneesheer veelvuldig ais motief aangevoord am vage kachten to ondersteunen. Voor oen adequate behandeling van do meerderheid van dete gevalten in een algemeen medische kennis voldoende.

$\begin{array}{lllllllllll}1 & 1 & 2 & & 3 & 3 & 4 & 1 & 5 & 5 & 6\end{array}$

Vr. 4: se bevolking moet tot een vergtandige zienswize opgevoed worden ten overstaan wan de mogeligheden en grenzen van do dokterstups.

$\begin{array}{rlllllllll}1 & 1 & 2 & 1 & 3 & 1 & 4 & 1 & 5 & 1\end{array}$

\section{HOOFDSTUK IV}

\section{DE DOKTER-PATIENT VERHOUDING}

\section{(Antwoord zoveel mogeltik in termen van uw spectaliteit !)}

Vr. 1: "Om lol een doaltreflende behandeling van de patient te kunnen overgaan hoeft de verhouding tussen geneesheor on patiekt vlot le verlopen $*$.

\begin{tabular}{|c|c|c|c|c|c|c|}
\hline $\begin{array}{l}\text { Vallodig } \\
\text { akkoord }\end{array}$ & Akkoord & \pm Akkoord & $\begin{array}{l}\text { Moeilijk te } \\
\text { oordelen }\end{array}$ & $\begin{array}{c}\text { Niet volledig } \\
\text { akkoord }\end{array}$ & $\begin{array}{c}\text { Niet } \\
\text { akkoord }\end{array}$ & $\begin{array}{c}\text { Absoluut } \\
\text { niet akkoord }\end{array}$ \\
\hline 1 & 2 & 1 & 4 & 5 & 6 & 7 \\
\hline
\end{tabular}

Vr. 2: "Voor hat benoud van een optimale, vertrouwenswolle dokter-patient verhouding is het wenselitk dat de dokter de beperktheid van zijn therapentisch kunnen niet veropenbaart aan de patient $*$.

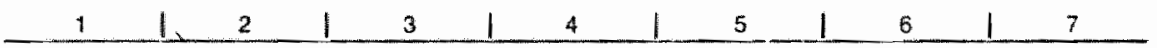


Vr. 3: "Hoe meet patienten de dokter heett, des te beter de dokterpatient verhouding wordt

$\begin{array}{lllllllll}1 & 1 & 2 & 1 & 3 & 1 & 4 & 1 & 5\end{array}$

Vr. 4: "Om een nawwe samenwerking van de patient te bekomen moet de geneesheer er over waken dat:

- de patient de beslissing van de geneesheer niel betwist

$\begin{array}{llllllllll}1 & 1 & 2 & 3 & 3 & 4 & 1 & 5 & 5 & 1\end{array}$

- de patient zinn emotionele conticten bedwingt

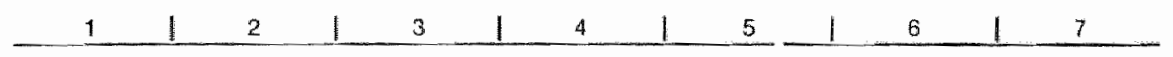

- de patient de geneesheer idealiseert

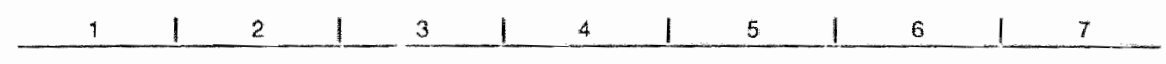

- de patient een zekere graad van ahankelighoid van da gencesheer ontwikkett

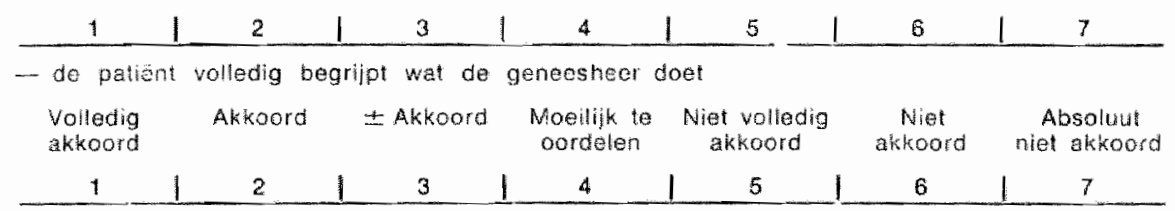

Vr. 5: "voor eest adequate behandeling van de petiont is het over het algemeen wenselik dat de geneesheer de patiënt ontrekt aan de invloed van zijn gezin $*$

$\begin{array}{lllllllll}1 & 1 & 2 & 1 & 3 & 1 & 4 & 1 & 5\end{array}$

Vr. 6: "De werkzämheid van heel wat geneesiniddelon en behandelingsmethoden wordt cerder gestmeleerd door het ventrouwen van de palient in de genecsheer die ze voorschrifl of togdient dan door het geloal van de patient in de objectieve werkzamheid van de be wuste geneesmiddelen en behandelingen zelf $\mathrm{m}$.

\begin{tabular}{|c|c|c|c|c|c|c|}
\hline 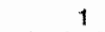 & 2 & 3 & 4 & 5 & 6 & 7 \\
\hline
\end{tabular}

Vr. 7 : De overiviging van de dokter dat een gegeven geneesmiddel werkelijk effect heefl be. paalt ook in grole mate hel wezenligk eifect ervan op het herstel van de patient.

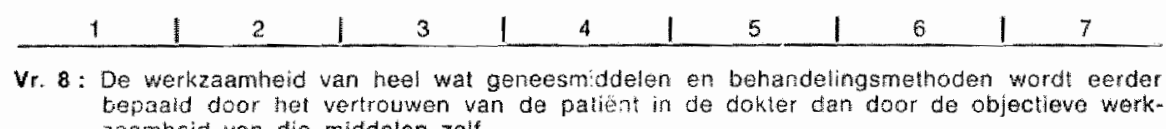
zamheid van die middelen zelf.

1
-1 $\quad 2 \quad 1 \quad 3 \quad 1 \quad 4 \quad 1 \quad 5 \quad 5 \quad 1 \quad 6 \quad 5 \quad 1 \quad 7$

HOOFOSTUK $V$

\section{VOLGENDE VRAGEN BETREFFEN DE GESPREKSITUATIE VAN DE GENEESHEER \\ (Antwoord zoveal mogelijk in termen van uw speclalfteit !)}

woor de kindereris bwb. zin de ouders van het kind meestal de gesprekparners on is ook do moeder wol eans patiente)

Vr. 1: Wannear de geneesheer over het wearom van de voorgegleide therapie vitteg verstrakt. doet hil dit :

- om de palient gerust 16 stellen

\begin{tabular}{|c|c|c|c|c|c|c|}
\hline $\begin{array}{l}\text { Volledig } \\
\text { akkoord }\end{array}$ & Akkoord & \pm Akkoord & $\begin{array}{l}\text { Moeilijk te } \\
\text { oordelen }\end{array}$ & $\begin{array}{c}\text { Niet volledig } \\
\text { akkooro }\end{array}$ & $\begin{array}{l}\text { Niet } \\
\text { akkoord }\end{array}$ & $\begin{array}{l}\text { Absolut } \\
\text { wet akkcord }\end{array}$ \\
\hline 1 & 2 & 3 & 4 & 5 & 6 & 7 \\
\hline
\end{tabular}

- om zeker te zign dat de patient het voorschrift zou volgen

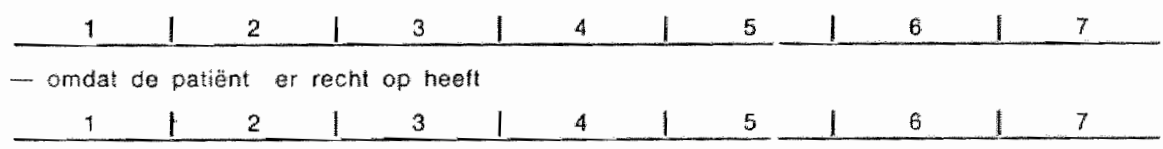


- omodat dan eerst samenwerking mogelijk is

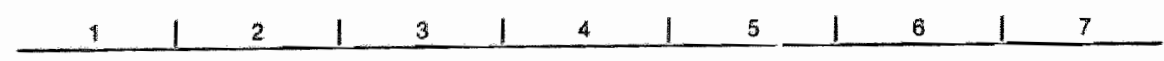

- om een nieuwe of ergere aandoening te voorkomen

$1 \quad 1 \quad 2 \quad 1 \quad 3 \quad 1 \quad 4 \quad 1 \quad 5 \quad 1 \quad 6 \quad 1 \quad 7$

Vr. 2: “ De meerdemeid van de patienten brengen de doktex door hum openheid in het gesprek op een spoor dat niet zuiver medisch is. maar dat nuttig is bij het stellen wan een diagriose $\cdots$.

\begin{tabular}{|c|c|c|c|c|c|c|}
\hline $\begin{array}{l}\text { Volledig } \\
\text { akkoord }\end{array}$ & Akkoord & I Akkoord & $\begin{array}{c}\text { Moeilijk le } \\
\text { oordelen }\end{array}$ & $\begin{array}{l}\text { Niel volledig } \\
\text { akkoord }\end{array}$ & $\begin{array}{c}\text { Niet } \\
\text { akkoord }\end{array}$ & $\begin{array}{l}\text { Absolut } \\
\text { net akkcord }\end{array}$ \\
\hline 1 & 2 & 3 & 4 & 5 & 6 & 7 \\
\hline
\end{tabular}

Vr. 3: "Utlog geven aan de patient doet over hel agemeen meer kwaad dan goed".

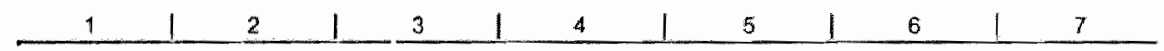

Vr. 4: Het publiceren in tal van dag. Bn weekoladen van medische artikels doet over het algemoen meer kwaad dan goed.

$\begin{array}{lllllllllll}1 & 1 & 2 & 1 & 3 & 1 & 4 & 1 & 5 & 1 & 6\end{array}$

Vr. 5: "De medische witzendingen van de onderccheiden T.V zenders zijn, als een noodzakelike informatie aan het brede publiek, aan te moadigen *.

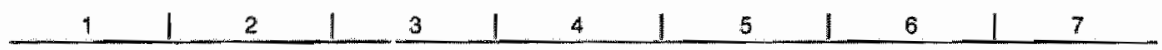

Vr, 6: Het slaat de dokter wrij een patient die een ziekte voorwendt, al dan niet uitleg te geven over zijn weigering een medisch attest af te leveren.

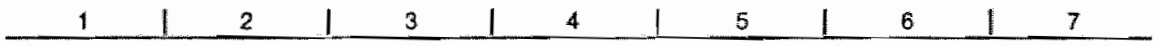

Vr. 7: "Wanneer een a paliont o openlijk bekent dat hij niet ziek is, maar wegens zekere moeilikkheden on een modisch voorschrift verzookt is de dokter ntet verplicht zilin welgering nader te omschrijuen .

$\begin{array}{llllllllll}1 & 1 & 2 & 1 & 3 & 1 & 4 & 1 & 5 & 1\end{array}$

Vr. B : "Het intelligentiepell van de patient bejaalt grolencieels of do dokter tot een gesprek zal overgaan dat niot louter de andoening van de patient betreft w.

\begin{tabular}{|c|c|c|c|c|c|c|}
\hline 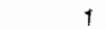 & 2 & 3 & 4 & 5 & 6 & 7 \\
\hline
\end{tabular}

Vr, 9: "In do regel zal de dokter eerder een gesprok van nief-medische aard voeren met patiètien die op een ongeveer gelijk inteligenticnwegu staan äs hij dan met andere w.

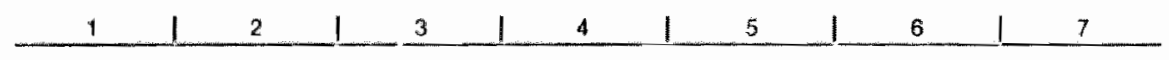

Vr. 10: "Over het algemeen is het aangowezen dal de dokter evantueet op het einde van het gesprek aan ziln patiënt volgende vratg stelt: "Wat vanuacht $U$ nu van mij ?

$\begin{array}{llllllll}1 & 1 & 2 & 1 & 3 & 4 & 5 & 1\end{array}$

\section{HOOFOSTUK VI}

\section{DE PAEVENTIE}

Vr. 1: "Zlektopreventie is als medische activiteit in de eerste plaats eerder een activiteit van openbare gezondheidsclenston dan van de praktiserende geneesheer

\begin{tabular}{|c|c|c|c|c|c|c|c|}
\hline $\begin{array}{l}\text { Volledig } \\
\text { akkoord }\end{array}$ & Akkoord & \pm Akkoord & & $\begin{array}{l}\text { Moailik te } \\
\text { cotdelen }\end{array}$ & $\begin{array}{c}\text { Niel volledig } \\
\text { akkoord }\end{array}$ & $\begin{array}{l}\text { Niet } \\
\text { akkoord }\end{array}$ & $\begin{array}{l}\text { Absoluwt } \\
\text { net akkoord }\end{array}$ \\
\hline 1 & 2 & 3 & 1 & $\Leftrightarrow$ & 5 & 6 & 7 \\
\hline
\end{tabular}


Vr. 2: "Preventie veronderstelt alteszins een zekere kennis vatwege de geneesheer over de houding wan de pationt ten overstaan var ziekte en gezondheid en dif is een laktor die in de geneeskundige praktik nag onbestacnde is *

\begin{tabular}{|c|c|c|c|c|c|c|}
\hline $\begin{array}{l}\text { Volledig } \\
\text { akkoord }\end{array}$ & Akroord & \pm Akkooro: & $\begin{array}{c}\text { Moeilijk te } \\
\text { oordeten }\end{array}$ & $\begin{array}{c}\text { Net volledig } \\
\text { ak koord }\end{array}$ & $\begin{array}{c}\text { Nie! } \\
\text { akkoord }\end{array}$ & $\begin{array}{l}\text { Absoluut } \\
\text { niot akkoord }\end{array}$ \\
\hline 1 & 2 & 3 & 4 & 5 & 6 & 17 \\
\hline
\end{tabular}

Vr. 3: "Aangezien de preventie van een zekte rechstreeks gecoreleotd is met de aard van de ziekle zelf en met has sociale bij-oorzaken is er geen bizonder reden on de medicosociale preventie in afzonderifjke cursussen te onderrichton ".

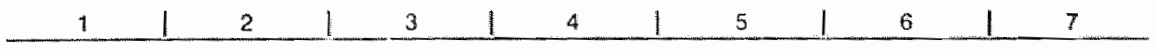

Vr. 4: "In de tegenwoordige praktik is de vraag voor ziektebehandeing zo groot dat nauwelijks erige lijd kan besteed worden on zich met preventie bezig te houden

$\begin{array}{llllllllll}1 & 1 & 2 & 1 & 3 & 1 & 4 & 5 & 5 & 5\end{array}$

Vr. 5: "Bovendien is te specitieke kennis dia nodig is om aan medico-goclale preventio te doen op dit ogenblik nog zo beperkt tal de tijd var to geneosheer veet beter besteed word aan louter curatieve zorg"

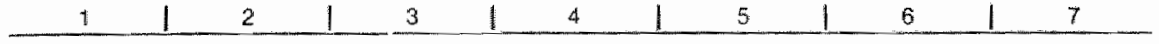

Vr. 6: "Wek beiang kent U toe aan de hieron for opgesomde diensten van preventieve genees. kunde?

-. bevokingsonderzoeken over diabetes, tuberculosis. enz.

\begin{tabular}{|c|c|c|c|c|c|c|}
\hline $\begin{array}{l}\text { Viterst } \\
\text { belangriak }\end{array}$ & Belangrijk & \pm Belangrijk & $\begin{array}{l}\text { Moeilijk te } \\
\text { oordelen }\end{array}$ & $\begin{array}{l}\text { Niat erg } \\
\text { belangrijk }\end{array}$ & Onbelangrilk & $\begin{array}{c}\text { Absolutut } \\
\text { onbelangrizk }\end{array}$ \\
\hline 1 & 2 & 3 & 4 & 5 & 6 & 17 \\
\hline
\end{tabular}

- medisch toezicht van jonge arbeiders

\begin{tabular}{|c|c|c|c|c|c|c|}
\hline 1 & 2 & 3 & 4 & 5 & 6 & 7 \\
\hline \multicolumn{7}{|c|}{ - medisch schooltoezicht } \\
\hline 1 & 2 & 3 & 4 & 5 & 6 & 7 \\
\hline
\end{tabular}

- medische sportonderzoken

$\begin{array}{lllllllll}1 & 1 & 2 & 1 & 3 & 1 & 4 & 1 & 5\end{array}$

Vr. 7 : Welk bolang hecht $\mathrm{U}$ aan:

- vaccinaties legen polio, difteritis, tetanus, enz.

\begin{tabular}{|c|c|}
\hline 1 & 2 \\
\hline
\end{tabular}

- regelmatig algemeen preventiel medisch onderzoek in de private pratilik

\begin{tabular}{|c|c|c|c|c|c|c|}
\hline 1 & 2 & 3 & 4 & 5 & 6 & 8 \\
\hline \multicolumn{7}{|c|}{$\begin{array}{l}\text { Yr. 8: "De patiënten wensen tegenwoordig ankel zo viug mogelik van hun ziekte verlost lo } \\
\text { worden. zin voor een preventief optreden wan de geneesheer heborn zij niet, zodat er } \\
\text { dan ook geen teden bestaat opdat de geneesheer bij zijn patienten nedruk zou leggen } \\
\text { op hel voorkomen van ziekten s. }\end{array}$} \\
\hline $\begin{array}{l}\text { Volledig } \\
\text { akkoord }\end{array}$ & Akkoord & \pm Akkoord & $\begin{array}{l}\text { Moeilik te } \\
\text { oordeten }\end{array}$ & $\begin{array}{c}\text { Niet voltedig } \\
\text { akkoord }\end{array}$ & $\begin{array}{c}\text { Niet } \\
\text { akkoord }\end{array}$ & $\begin{array}{l}\text { Absolutit } \\
\text { nigt akkoora }\end{array}$ \\
\hline 1 & 2 & 3 & 4 & 5 & 6 & 7 \\
\hline
\end{tabular}


HOOFDSTUK VII

\section{TEAMWOAK IN HET KADER VAN DE CURATIEYE GENEESKUNDE}

\section{(Antwoord zoveel mogelfith in fermen van uw speclatteit)}

\section{A. Medisch teanwork in het algemeen}

Vr. 1: Wek belang hecht $U$ aen de herravolgcnde elementen die in een mecisch leam op treden:

- de gedolde verantwoordelikheid in de zorg aan de zieke

\begin{tabular}{|c|c|c|c|c|c|c|}
\hline $\begin{array}{c}\text { Ulterst } \\
\text { belangrish }\end{array}$ & Selangrijk & * Selangék & $\begin{array}{c}\text { Mculink te } \\
\text { oordolen }\end{array}$ & $\begin{array}{l}\text { Nien erg } \\
\text { belamgrik }\end{array}$ & Onbelangrik & $\begin{array}{c}\text { Absolutit } \\
\text { onbolangeifk }\end{array}$ \\
\hline 1 & 2 & 3 & 4 & 5 & 6 & 7 \\
\hline
\end{tabular}

-... de struenbundeling van de technische kennis

\begin{tabular}{r|r|r|r|r|r|r}
1 & 2 & 3 & 4 & 5 & 5
\end{tabular}

- de intense samenwerking voor het weziln van de palient

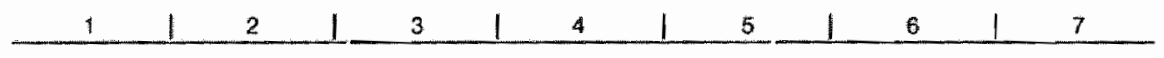

Vr. 2: "De goneesheer die in ean team samenwerk met een psycholoog. een sociale werker, een verpleogster of ander paramedisch personee moet eerder een uitgesproken direc. liewe dan een coordinerendo postio inemen opot de behandeling elfectief zou zin ".

Volledig Akkoord \#Akkoord Moeilizk to Niet volledig Niet Absoluut akkcord pordaken akkoord akkoord niet akkoord

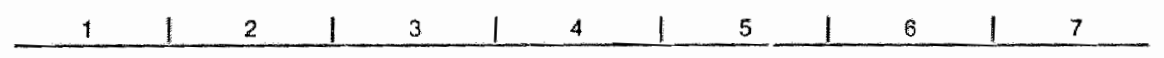

Vr. 3: "Vindt $U$ dat het imwinnen van inlichlingon over milieutactoren in verband met de $z$ lekte van ean patlent over het algemeen de laak is van:

- Je sociale assistente - de (mediscti) secretaris

- de verpleegster - de genesheer

V. 4: Het inwinnen van dergelljke informatie is

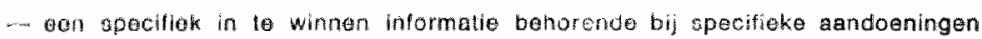

\begin{tabular}{|c|c|c|c|c|c|c|}
\hline $\begin{array}{l}\text { Vollodig } \\
\text { akkoold }\end{array}$ & Akkoord & * Akmoord & $\begin{array}{c}\text { Modilik to } \\
\text { oordelen }\end{array}$ & $\begin{array}{c}\text { Nifi volledig } \\
\text { aksoord }\end{array}$ & $\begin{array}{l}\text { Niet } \\
\text { axkooto }\end{array}$ & $\begin{array}{l}\text { Absoluut } \\
\text { net akkoord }\end{array}$ \\
\hline 1 & 2 & 3 & 4 & 5 & 6 & 7 \\
\hline
\end{tabular}

- est speciliek in to winnen hormatio behorande bil bepaalde zieken

\begin{tabular}{|c|c|c|c|c|c|c|}
\hline 1 & 2 & 3 & 4 & 5 & 6 & 7 \\
\hline - roulir & & & & & & \\
\hline 1 & 2 & 3 & 4 & 5 & 6 & 7 \\
\hline
\end{tabular}

Vr. 5 : Wannear tich ean patient bil do dokter anbiedt met vage klachlen en de dokter vermogd dat enkel beroepsmoelijkheden ar de oorzack van zijn. is het eerder aangewezen de palient nas con larzake bevougd persoon (een sociaal raadgever bub.) te verwijzen. dan to pogen zalf die moelliktreden op ta lossen.

\begin{tabular}{|c|c|c|c|c|c|c|}
\hline $\begin{array}{l}\text { voliedig } \\
\text { akkoord }\end{array}$ & Akkoord & -t Akkoord & $\begin{array}{c}\text { Moollik te } \\
\text { oordelen }\end{array}$ & $\begin{array}{c}\text { Not voltedig } \\
\text { akkoord }\end{array}$ & $\begin{array}{l}\text { Niat } \\
\text { akkoord }\end{array}$ & $\begin{array}{c}\text { Absolud } \\
\text { niet akkoord }\end{array}$ \\
\hline 1 & 2 & 3 & 4 & 5 & 6 & 7 \\
\hline
\end{tabular}


V. 6 : Gelieve het belang wht te drukken dat U toekent aan de arnwezigheid van de vermelde beroepen in do heronder aungedude diensten. Galleve geen onkele puntenschas te vergeten! Dit is zeer belangrijk).

- De aanwezigheid van cen sociaal assistentle) is In een ziekentuis

\begin{tabular}{|c|c|c|c|c|c|c|}
\hline $\begin{array}{l}\text { Uiterst } \\
\text { belangrijk }\end{array}$ & Belangrijk & I Belangrijk & $\begin{array}{l}\text { Moeilik to } \\
\text { cordeten }\end{array}$ & $\begin{array}{l}\text { Niet arg } \\
\text { belangrik }\end{array}$ & Onbolangritis & $\begin{array}{l}\text { Absolutu } \\
\text { onbelangrijk }\end{array}$ \\
\hline 1 & 2 & 1 & 4 & 5 & 6 & 7 \\
\hline
\end{tabular}

In de private praktik van de hrisarts

1
1

in da privete praklik van de speciatist

$1 \quad 1 \quad 2 \quad 1 \quad 3 \quad 1 \quad 4 \quad 1 \quad 5 \quad 1 \quad 6 \quad 1 \quad$

- De arnwezigheid van cen social verpleegster is

in een ziekenhuis

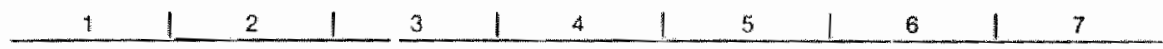

in de private praktik van de huisarts

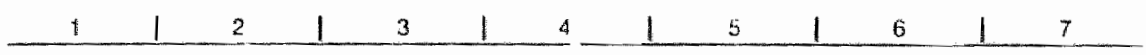

in de priwate praktik van de speciatist

$\begin{array}{lllllllll}1 & 1 & 2 & 1 & 3 & 4 & 4 & 1 & 5\end{array}$

- De atanezigheid van een verpleegster is

in een ziekentuis

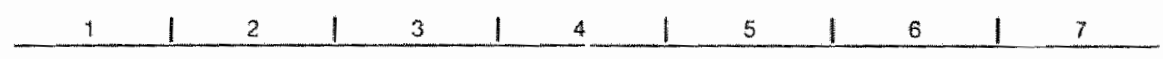

in de private praktijk van de huisarts

$\begin{array}{lllllllllll}1 & 1 & 2 & 1 & 3 & - & 4 & 1 & 5 & 1 & 6\end{array}$

In de private praktijk van de specialist

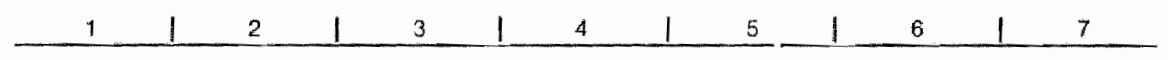

- De aanwezigheid van een psychologisch assistent is

in een ztekenhuis

\begin{tabular}{lllllllll}
1 & 1 & 2 & 3 & 1 & 4 & 5 & 6 & \\
\hline
\end{tabular}

In de private praktik van de husarts

\begin{tabular}{|c|c|c|c|c|c|c|}
\hline $\begin{array}{l}\text { Uiterst } \\
\text { velangilic }\end{array}$ & Beangriak & - Belangriak & $\begin{array}{c}\text { Moelfik le } \\
\text { cordelesin }\end{array}$ & $\begin{array}{l}\text { Nel erg } \\
\text { belangrit }\end{array}$ & Onbelangrip & $\begin{array}{c}\text { Absoluu! } \\
\text { onbelangrijk }\end{array}$ \\
\hline
\end{tabular}

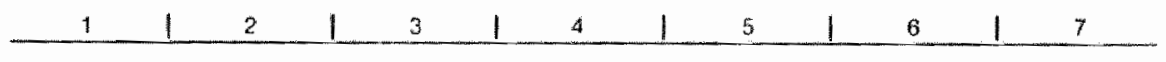

Wh te private pratijk van do specials?

\begin{tabular}{|c|c|c|c|c|c|c|}
\hline 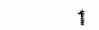 & 2 & 3 & 4 & 5 & 6 & 7 \\
\hline
\end{tabular}

\section{B. Teanwerk met collega's.}

Vr. 1: Mar wetke vorm wan medische plaklik gant uw voorkew

- individuele praktik warom? 
Vr. 2: Hoeft, afgevien van uw voorgaande keuze, hei leam of do groep samengesteld to ziln טif : (1)

- onksl omnipractici

- enkol spectalisten van dezelfde specialiteit

- enkel specialisten van verschiflende speciahteiten

- omnipractici + specialisten.

Vr. 3: In het tastste geval, abn wie hoort, naar uw moning. de coordinalie loe in de groep

- aan een omnipracticus

- aran cen speciatist

- aan een omnipracticus it een specialist

- Een en heterogeon comite

To beaniwoorden door hen die de groepogoneaskunde verkiezen.

Vr. 4: De groepsgeneeskunde is te verkezen bsven te individuete geneeskunde omdat: igeheve: do crlteria een rangrummer te geven):

- zill de geneteheer in stcat stelt zijn kennis te verrijken

Rangnummer

- zij van aard is de geneeskundige zorjon boter spreiden over de verschilleirdo medische specialiteiten. .

- 2ij de Inancialo inspanring van de individuslo geneesheer venticht.

- zil da kwaliteitszorg ten goede komt

- zil de geneesheer velaat ziji achiviteiten te planner.

- zij de geneeskundige praktik efficienier maaki

\section{HOOFDSTUK VIII}

\section{DE SPECIALISATIE IN DE MEDISCHE PRAKTIJK}

(Antwoord zoveal mogelljk in termen van uw speclalltelt i)

Vr. 1: a h de hedendagage mediche praktik zihn er voldoende geneesheren-specialisten opdat de omnipracticus nibt langer meer cen verantwoordelightheid over een lange termigh voor zijn patienten zou hoeven to dragen *.

\begin{tabular}{|c|c|c|c|c|c|c|}
\hline $\begin{array}{l}\text { Vollodig } \\
\text { akkoord }\end{array}$ & Akkoord & I Akkoord & $\begin{array}{l}\text { Moenilik to } \\
\text { oordelen }\end{array}$ & $\begin{array}{c}\text { Nist volledig } \\
\text { akkoord }\end{array}$ & $\begin{array}{c}\text { Niet } \\
\text { akkoond }\end{array}$ & $\begin{array}{c}\text { Absolut } \\
\text { niet akkoord }\end{array}$ \\
\hline 1 & 2 & 3 & 4 & 5 & 6 & 7 \\
\hline
\end{tabular}

V*, 2: "Do medische studies zouden meer op specialisatie dan op de algemene praktijk moeton geriat worden a.

\begin{tabular}{l|l|l|l|l|l|l}
1 & 2 & 3 & 5 & 4 & 5 & 1 \\
\hline
\end{tabular}

Vr. 3 : "Da Vrag naer medische verzorging is tegenwcordig zo groot en do spectalisatie voldoende geevolueerd dat de omnipracticus vael beter zijn tijd besteed aan echt zieke patiénten. dan aan emotionele gevallen ".

\begin{tabular}{ll|llllllll}
1 & 1 & 2 & 3 & 4 & 4 & 5 & 1 & 6 & 1 \\
\hline
\end{tabular}

Vr. 4: "Psychiatrische behandeling is voor de meardegheid der patienten meer ean recent luxusarikel dan een werketike noodzaak w.

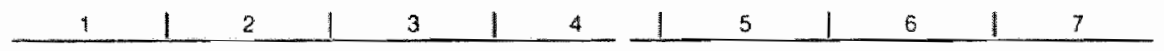

Vr. 5: .Voor een gemeeshoer is het belangriker dat hil zijn technische kennis perfectionneert dan det hij zin evaring met de persoon en het milieu van de patiènt verrillt w.

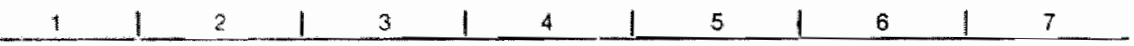


Vr. 6: De specialisatie van het medisch berop is den gevolg van een zich steeds verder oft wikkelende techniek Dit manifesteen zich ook in de farmacologie waat een uigebreide gamma van farmaceulic he werk van de geneosheer langs om meer vergemakkelikt. Zo laat het gebruih van sedativa dw geneesher toe gevallen van lichte hyperterisie suksesvol se behandelen.

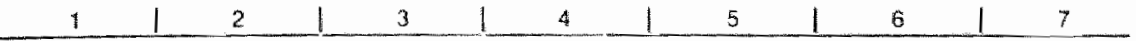

Vr. 7 : "Een specialist voor neus. keel- en oorzieklen zou over hel algemeen minder elfectiet zin bij een routine-huisbezoek dan een omnipracticus

$\begin{array}{lllllllll}1 & 2 & 1 & 3 & 1 & 4 & 1 & 5 & 1\end{array}$

Vr. 8: "Het kader van medico-sociate diensten is u de moderne samenteving reeds zo uitgebreid dat de dokter zin hid net neer hoelt te verliezen om problemen van persoontijke. familiale of protessionele aard van de patienten te bespreken of op te lossen is.

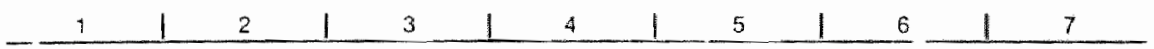

\section{DEEL I}

Dit deel van de vragenlist omwat en reeks vagen be betrkking hebben op zekere activiteiten die $U$ antplooit en op eventuele contacten met callegae. met para-medisch personeel on mot de zieken zelf.

Voor de meeste vragen hoeft $U$ enkel een $X$ te platsen, te onderijnen wat past on bif witzon. dering een zeer bondig antwoord le verstrekken.

(De vakges rechts aan de rand zijn code vakies cloor de onderzoeker in te vullen.)

\section{HOOFOSTUK।}

\section{DOCUMENTATIE-ACTIVITEITEN}

Vr. 1: Wanneer $U$ zich naast het overleg met coliegae over bepalde ziektetoestanden in modische publikaties documenteen, zijn het dan:

-m Standaardwerken op hel gebied wan de algemene geneeskunde

- Specialisatiewerken

- Algemeen medische tijdsthriften

- Specialistische medische tijochriften

Vr. 2: Weke van de vier gencemde dokumenten helpen U doorgans het best?

- algemene standardwerken

- specialisatiewerken

- algemeen mediscte tiguschriften

- specialistische tijoschriften

Vr. 3: Woonde 4 reeds:

- Hocale of regionale

- nationale

- internationate

medsche congressen il culloqua bij?

Vr. 4 : Indien ja. was dal:

- op algemeen medisch văk

- op hel gebied van uw specialiteit

- op hel gebied van een andere medische fichtng dan de uwe (wok ?)

Vr. 5 : Volgde U reeds posi-universitaire leargangea op nedech gobied?

$$
\text { Ja - neen }
$$


Vr. 6: Indien ja. was dat:

- op algemeen nedisch wak

- op het gebied van uw specialiteit

- op het gebied wan een andere mediscie pichting dan de wwe (welk?)

Vr. 7 : Gelieve in do hiaronder vermelde medische richlingen in orde van belengrikheld er drie aan te duiden waarvoor $U$ behalve voor uw eigen vak, nog een bijzondere belangstelling koestert laanduiden met $1+=$ meest be iangstelling. $2+\ldots .3+\ldots$ ).

Gelieve ar ook drle aan le duiden waorvor $U$ hel minsl belangstelling hebt $1-=$ minst belargstelling. $2-\ldots, 3-\ldots$
1. Anesthesiologio
11. Orthopaedie
2. Biologie
3. Cardiologie
12. News, keel, oor
4. Heolkunde
13. Kindargenceskunde
5. Dermato-Venereologle
14. Physiotherapie
6. Maag-en Darmengenaeskunde
15. Pneumologie
7. Gynaecologio
ic. Radiologie
8. Inwendigo geneeskundo
i7. Feumatologie
9. Neuro-psychiatrio
;8. Stomatologie
10. Oogheeikunde
19. Urologie
20. Andere (welke ?)

V. 8: Gelleve in orde van belangrilkhcld drie niet-medische gebieden op to sommen waaraan $U$. zo $U$ er de tijd voor vindt, een bijzondere belangstelfing hecht of bepaalde activiteiten ontplooit (hetzi door lectuur, hetzif door actiel optreden, enz.).

1.

2

3.

HOOFDSTUK

\section{CONTACTEN MET COLLEGAE}

Vr. 1: Gelieve in de hienavolgende tabel:

16 Drie geneeskundige speciahtellon (ook ombipaklik) aan te duiden (kolom 1) met de. weke $\mathrm{U}$ zelf in de loop van uw prak ik te veluddiget contact opheernt voor advies: intormalls consult, verwigen (kolominon 2., 3. en 4,). (")

$2^{4}$ Aan te duiden in kolommen 5 en 6 . of de samenwerking op contractuele grond gebeur: of enkel occestoneet is. $\left({ }^{\prime}\right)$

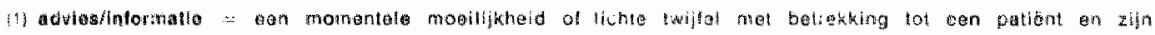

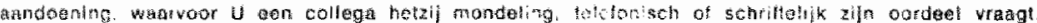

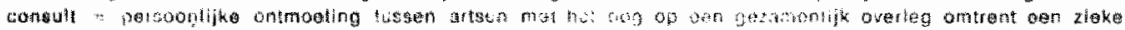

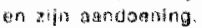

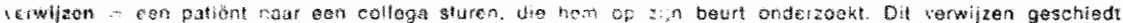

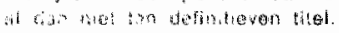

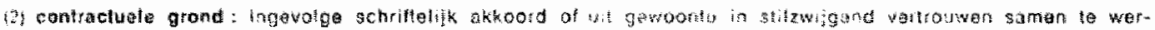
nom mat en ol moordero collegas. 


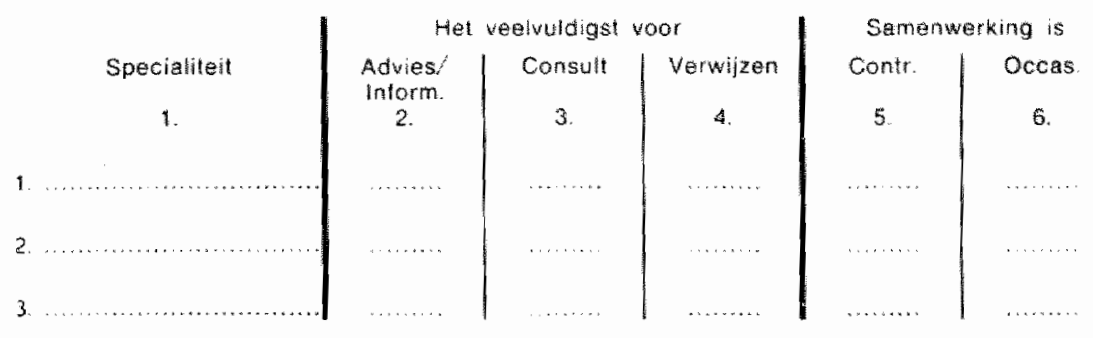

Vr. 2: Geschieden de contacten met collegae voor advies/intormatie hoofdzakalik:

$$
\text { mondeling - schriftelik - teblonisch }
$$

Vr. 3: Gelleve if benaderende procenten aan te duiden wor hoever val uw ziektegevallen $u$ lijdens een tijdsverloop van bub. én jaar:

\section{Benaderende Procenter}

- vitsluitend persoontik optreedt.

- U bil collegae on advies of informatie verzoekt

- U met collegae in consult komt

- U de patient zelf nat collegee verwijst

Vr. 4 : Wanneer $U$, hetzij voor informatie of advies, hetzil voor consult, een collega hebt geconlacteerd, vaelt $U$ zich dan verplicht de opinie van die collega zonder reserve to aanvaarden?

Nooit - zelden - vaak - meestal - altijd

Vr. 5 : Wanneet U, na bethandeling van een patient, volgens de voorschriften düe U door aen collega op uw verzoek verstrekt werden, gowaar wordt dat de bohandeling weinig of goen resultaat opleverde

- voett $U$ zich dan persooniljk veraniwoordellik

- oordeelt $U$ dat uw collega eerder vemantwoordelijk is. 
HOOFDSTUK in

YOLGENDE VAAGEN BETREFFEN EVENTUELE HULPKAACHTEN DIE U IN UW PRAKTIJK TEA BESCHIKKING HEET

A. De viagen 1 an 2 zin te beantwoorden door geneesheren die vaste of occasionele hutphrachten ler beachiking hebben (de huip van de echigenole. hoe belangrik die ook moge zin. hoeft net vermeid (e worden, tenzll zil howjster is van een van de hema vermelde diploma's] (l).

Vr. 1: Wethe van de hieronder opgesomde categoreen hulpkachten:

Staan U iepzide in un privale prakiffk

1. Gegrad. verpleageter. verpleagtor. zieken.

oppasser, vroedirouw kirdervorzorgster enz.

II. Socian verpleggster sociabl assisteritle) onz

111. Med. secrataris secte. laris, enz.

1V. Psychologisch assistent. psycholoog. onz.

V. Dítlst, kinesist, audiologist, laborant, enc. is dit.. vast of Occas

\author{
Worden $U$ ter beschikking \\ gesteld in te instelling(en) \\ war $U$ uw prakifik vitoetent
}

V. 2: Weke van de hiaboven door $U$ angadude hulpkrachtienl treden rechistrens in contact met uw patienten voor het inwinnen ban inichtingen van persoonlike. familiaia of prolessionele ard.

Categorie $1-\|! \cdot\| l \mid-I V-V$

Q. Enkal le beantwoorden door geneesheren die geen vaste of occasionele huipkracht(en) ter beschikking hebben.

Vr. 3 : Kwam hel $U$ reeds voor dat $U$ in de whoetening van uw prakiik een patient vervees nat:

- aen ergo-therapeut dietist, logopedist enz.

10 - neen

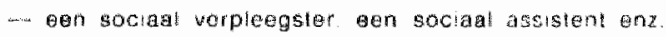

in - neen

- cen psycholoog. ton psychologisch asistent

ia - neer

- aon laminle nelpster

ja: nean

-.. aon medico-sociale dienst

$1 a$ - neen

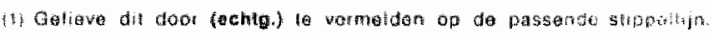




\section{Door federeen te beantwoorden:}

Vr. 4: Hebt $U$ reeds rechtstreeks ondervonden, dat de behandeing van een patient vergemek. kelijkt werd. door hel optreden van:
- een sociaal verpleegster
ja neen
- een sociaal assistent
jo - neen
- een psycholoog
ja. neen
- cen faminate hepsier
ja - neen
- een medico-sociale dienst.
je - neen

Vr. 5 : Vindt $\mathrm{U}$; dat het optreden van hulpkrachten, zoals...

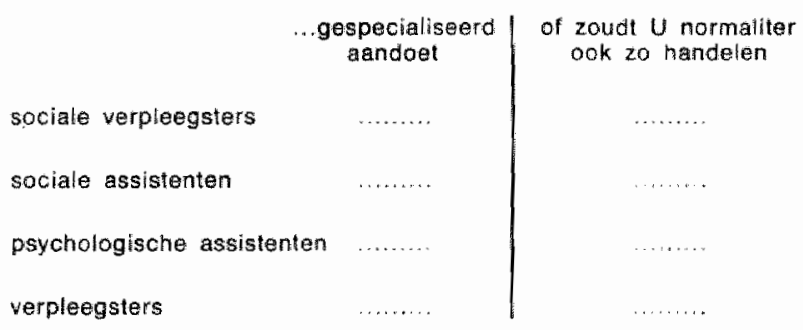


HOOFDSTUK IV

\section{CONTACTEN MET PATIENTEN}

Vr. 1: Welke pationten behandelt

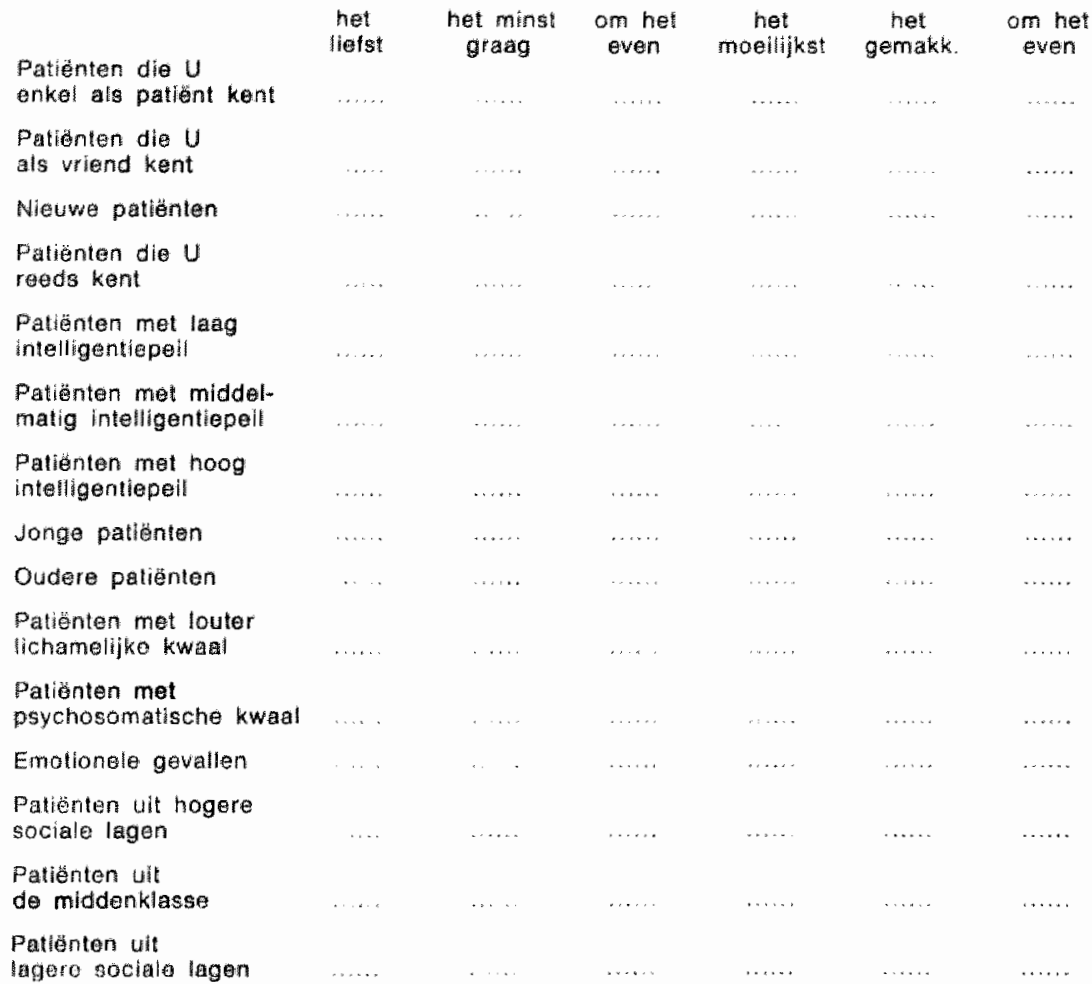

Vr. 2: Gollave op de volgende vraag te antworden door onder elk van de gepresenteerde situa-

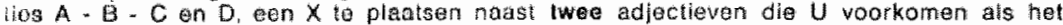
beal passend bif de betrettende situatie (duid dis twee adjectieven aan per situatiel.

VRAAQ: Hoe beoordeolt $U$ over het algemeen patienten:

A. Die vcorateer $U$ zelf een diagnose stelde of en heolmiddel (behandeling) voor* schroe, reeds voor zichzelf dagnosticearden en bovendien om en bepaald medicament verzoken.

B. Die aan $U$ alleen het initatief laten en geen vitleg vragen.

C. Ole aan $U$ alleen het inillatief laven. doch wet om uitleg vragen.

D. Die an $U$ alteen het initiatief laten, doch enigszips uw beslissingen in twiffel tokken. 
Situatle A

Shuatie $B$
1. actiel
1. bescheiden
2. angstig
2. coóperatiel
3. arrogant
3. gemakzuchilg
4. coöperatief
4. gereserverd
5. dominerend
5. goedaardig
6. egocentrisch
6. lovenswaardig
7. emotioneel
7. niet-cooperatiet
8. ondernemend
8. ondoordacht
9. vervelend
9. sympathiek

Situatie $C$

Situatie D

1. coöperatief

1. actiel

2. detensief

2. agressief

3. gecomplexeerd

3. defensiet

4. nueuwsglerig

4. emotiones

5. prijzensweardig

5. gecomplexeord

6. rationeal

6. individualistisch

7. rechtmatig

8. vervelend

7. niet-coöperatief

9. vooruitziend

8. ruttig

9. rationeel

HODFDSTUK $V$

SOORTEN PATIENTEN

Nota: 1. Voor alle vragen worden enkal benaderende procenten gevraagd.

2. Zo het $U$ vanuit het oogpunt van uw specialiteit, onmogeligk is bepaalde procenten te verstrekken, gelieve dit te vermelden a.u.b.).

Vr. 1: Hoeveel wan uw patienten bezoekt of ontvangt u?

$$
\begin{aligned}
& \text { Per zlektegeval } \\
& -1 \text { a } 2 \text { maal } \\
& -3 \text { a maal } \\
& -5 \text { a } 6 \text { maal } \\
& \text { - meer }
\end{aligned}
$$

Bensiderend

$100 \%$

Yr. 2 : Hoeveel procent van uw patiënten bezoekt of ontvangt U ?

Per láar

Benaderend

1 畜 2 maal

-3 a 4 maal

- 5 a 6 maal 
Vr. 3: Hoeveel of van uw patienten hebt $U$, te rekenen vanaf het eerste contact. $t 3$ degen. in behandeling $?$ (ongeacht de frequentie van de bezoeken).

\section{Benaderend}

$$
\begin{aligned}
& \text { - } 1 \text { d } 3 \text { dagen } \\
& \text { - een woek } \\
& \text { - twee weken } \\
& \text { - een maand } \\
& \text { - lwee maanden } \\
& \text { - vigt maanden } \\
& \text { - zes maanden } \\
& \text { - langer. }
\end{aligned}
$$

$100 \%$

Vr. 4: Gelieve uw pationten in te delen naargelang $U$ :

$$
\text { Benad. } \%
$$

-uen enkel persoon van het gezín beinandelt. .

- twee personen van hetzelfde gezin bohandeit

- gans het gezin behandel.

Vr. 5: Verstlekt U soms, buiten het woton van uw patient, raadgevingen of uitleg aan zijn gezinsleden?

$$
\text { Ja - neen }
$$

Zo je. doet U dit dan (in orde van belengrijkheld nummeren van 1 tot 6$)(1=$ het meest balangrijkj.

\section{Rangnummer}

- om betare samenwerking van de patient te bekomen

- om alleszins zeker to ziln dat de patient uw voorschriften zou volgen

- om de gezinsieden op hun plichten 10 wijzen.

- om te voorkomen dat de gezinsladen zelt de kans zouden lopen ziek te worden.

- om te voorkomen diat de patient oventueel hervals

- andere (wolko) ? 
Vr. 6 : Gelieve uw patienten in te delen nargelang de gezondheidstoestand wan het gezin.

Banad. $\%$

- gezond

- af en toe oen kleine zlekte.

- ziekelijk

$100 \%$

Vr. 7 : Kunt $\mathrm{U}$ ze ook indelen naargelang $\mathrm{U}$ denkt dat zil uw voorschriten:

Benad. \%

- nauwgezet volgen

- min of meer volgen

- niet volgen

$100 \%$

Vr. 8 : Idem naar U denkt dat zil :

Benad. \%

- een goed begrip hebben van een hygienische levenswize.

- er min of meer begrip voor hebben

- er helemal geen begrip voor hebben

$100 \%$

Vr. 9: Idem naar sociale laag waartoe zij behoren:

Benad. \%

- arbeidersklasse

- kieine burgeril

- burgerij

gegoede burgeri

-... zeer gegoede burgeril

$100 \%$

Vr. 10 : Op hoeveel schat $U$ het procent van uw patienten die, moesten zil enigszins alt, neenhygiènischer leven, geen zorgen zouden behoeven?

\section{$\ldots \ldots+7 / 6$}

Vr. 11: Op hoeveel schat $U$ het procent vam uw patienten die, moesten zil teen enigszing geesteshygiënische levenswijze laiden, geen zorgen zouden bahoeven ? 


\section{DEEL 111 \\ ALGEMENE INLICHTINGEN \\ HOOFOSTUK । \\ KEUZE VAN UW STUDIE}

Vr. 1: Op wetk tildotip dach $U$ er reeds ernstig aan geneeskunde te studeren:

- vóó tanvang van humaniora

- tijoans humaniora

- na bohalen van uw humaniora-diploma

- andere (specificeren a.u.b.)

Vr. 2: Whe zatte $U$ or in het bilzonder to an geneeskunde te studeren:

$$
\begin{aligned}
& \text { - ouders } \\
& \text { - tamilie } \\
& \text { - vrienden ten huiza } \\
& \text { - persoonlike vriend } \\
& \text { - schoolmakker } \\
& \text { - leraar } \\
& \text { - dienst beroepsorientering } \\
& \text { - eigen keuze } \\
& \text { - andere (specificeren a.u.b.) }
\end{aligned}
$$

Vr. 3 : Zo hot uw eigen keuze was, kunt $U$ dan zeggen. WAT or $U$ vooral toe bracht? (Wb. lectuur, prestige van het beroep, belangstelling om hat vak ais wetenschap, hulp aan medemens, financlele overwegingen, enz...).

(Vragen 4, 5,6 enkal door omnlpracticl te beantwoorden.)

Vr. 4 : Wanneer besliete $U$ de ommipraktilk to klezen on niet to specialtseren:

- reods tijdens uw humaniorastudies

- In do loop van uw candidatuurjaren

- In do loop van uw doctorastsjaren

- Iljons uw stageperlode

- na het behalen van uw diploma van geneesheer 
Vr. 5: Wie spoorde er $U$ toe aan de omnipraktijk te kiezen:

- ouders

- familie

- vrianden ten huize

- perscontike vilend

- studiemakker

- hoogleraar

- eigen keuze

- andere (specificeren a.tu.b.)

Vr. 6 : Zo het uw eigen keuze was, kunt $U$ dan zeggen WAT or $U$ vooral toe bracht?

(Vragen $7,0,9$ en 10 enkel door geneesheren-speclatisten te beantwoorden.)

Vr. $7:$ Zilit U: - reeds erkend specialist of

- specialiseen $U$ zich nog

Vr. 8: Welke specialiteit(en) becefent $U$ en hoelang reeds?

Specialiteit(en)

Hoelang

(in jaren)

1

2 .

3

4.

5

Vr. 9: Wanreer besliste $U$ zich te specialiseren on niet de omnipraktik to kiezen:

- reeds thdens uw humaniorastudies

- Ir de loop van uw candidatuurjaren

- in de loop van uw docloraatsjaren

- ijdens uw stageperiode

- na hel behalen van uw diploma wan geneesheer

- in de loop van uw praktik van omnipracticus

In dit laatste geval, hoeveel jaren ommipraktljk had U reeds ? .........

Vr. 10: Wie spoorde er U toe aan le specialiseren?

- ouders

- familie

- vriender ten huizo

- persoonlike vriend

- studiemakker

- hoogleraar

- collega

- eigen keuze

- andere (specificeren a.u.b.) 
Vr. 11: Zo het uw eigen keuze was, kunt $U$ dan zeggen WAT er U vooral toe bracht?

\section{HOOFDSTUK II \\ STUDIEMILIEU}

Vi. I: Diplomajear:

Vr. 2 : is, naar uw oordeel, uw academische opleiding in de traditionele gebleden van de geneeskunde adequal geweest?

$$
\text { ja - noen }
$$

Vr. 3: Indien neen ${ }_{\mathrm{r}}$ wat ontbrak naar uw oordeel aan die opleiding?

Vr. 4: Had U veel persoonlike contacten met uw professorengeneesheren tijdens uw studies?

$$
\text { Ja - Neen }
$$

Y. 5: Waren ze vaak uw persoonlijke radgever?

$$
\mathrm{Ja} \text { - Neen }
$$

Vr. 6 : Welke specialiteit heeft $U$ in de toop van uw studiejaren (stage inbegrepen) vooral geboeld? (desgevallend meerdere aanduiden)

Vr. 1: Soxe: Man - Vrouw

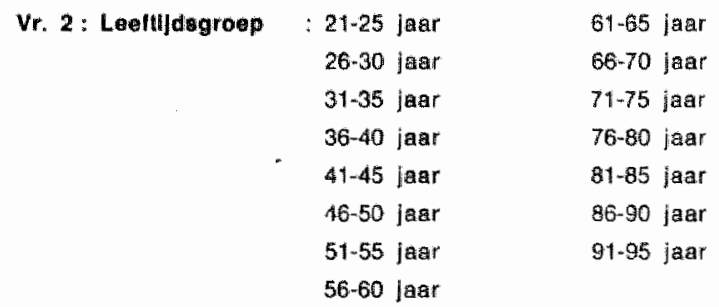

Vr. 3 : Beroep van vader

Vr. 4 : Beroep van moeder 
Vr. 5: Beroep van grootvader langs vaderlide

Vr. 6: Hebt $U$ broers of zusters of famillededen die omnipracticus, specialist, landarts, enz. zijn...

Broer(s) en/of zuster(s) Familetid (leden)

1. Omnipracticus

2. Specialist

3. Tandarts

4. Apotheker

5. Para-medisch beroep

6. Geneeskundige studies

7. Para-medische studies

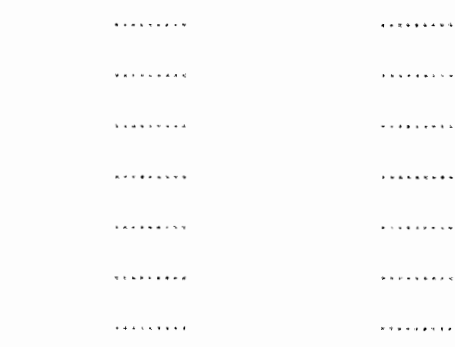

HOOFDSTUK IV

\section{ALGEMEENWEDEN OVEA UW PRAKTIJK}

Vr. 1: Hoeveel jaren praktijk hebt $U$ op dit ogenblik?

V. 2 : Oefent $U$ uw praktijk hoofdzakeligk of het langst vit

- ap het platteland

- in een kleine stad (- 25.000 inwoners)

- in de stad (meer dan 25.000 inwoners)

Vr. 3 : Defent $U$ op dit ogenblik:

- privato praktik uit

- praktilk verbonden aan een medische instelling

- praktijk verbonden aan een niet-medische instelling

Vr. 4 : Oetent $U$ een ambt ust

- aan een dienst van preventiave geneeskundo

- an cen dienst van openbare hygiene

V. 5: 2ljt $U$ ook verbonden aan medische instellingan of lid van verenigingen met louter madisch-wetenschappellik studie-karakter?

$$
\text { Ja - Neen }
$$

Yr. 6: Milieu waarin uw cabinet(ten) gelegen is (zijn):

- platteland

- stad : - arbeidersmilleu

- klein burgerlik milieu

- Burgeril milieu

- milieu gegoede burgers 
Vr. 7 : Gelleve arn te duiden hoeveel ind U gorriddeld PER MAAND desteed aan:

In uren of in degen

Conevitaties in cabinetten:

Ziekerbozoek tern huize

Ziekenbezoek in klthiek

Consult mot collega's

Pieventief geneeskundig onderzoek

Brelwisseing colfegats

Labowiterk

Situdiewark

lnopectio en controle

Onderwijs

Admin. werk (mutualteit, fiscus)

Vergaderingen op medisch vak 


\section{GERAADPLEEGDE LITERATUUR}

APPELS, A. : "Het hartinfarct een culturziekte ?" In:

"Tijdschrift voor Sociale Zekerheid", n०.50, 1972, blz. $446-448$.

BARKER, L.F. : "The specialist and the general practitioner".

In: "The Journal of the American Medical Association".

Vol.73, no.11, March 18, 1922, blz.775-776.

BECKER, H.S., GEER,BL.: "The fate of idealism in medical

school". In : American Sociological Review", Vol.23, Feb. $1958, b ! z, 50$.

BECKER,H.S., GEER,BL., HUGHES,E.C., STRAUSS,A.L.: "BOYS in White. Student culture in medical school", chicago, 1961. BERGSMA, I. : "Gezonde communicatie. Interdisciplinaire en andere communicatie in de gezondheidszorg". Lochem, 1971.

BERNT,I.J.A. : "Groepspraktijken en Gezondheidscentra".

Rotterdam, 1973.

CASSEE,E.Th. : "Naar de dokter. Enkele achtergronden van ziektegedrag en gezondheidszorg". 1973, blz. 113 en vlg.

DOHERTY,E.G., HARRY, J.: "Structural dissensus in the therapeutic community". In: "Journal of Health and Social Behavior", Vol.17, no.3, sept. 1976, blz. 272-279.

DOORN,J.A.A. (VAN): "Het medisch ventiel voor matschappelijk falen". In: "Sociologische Gids", 3, 1956, blz. 152-157. DON,C., COLLETTE,P., HIMAR, N.A. : "Career interests and Expectations of U.S. Medical students". In : "Journal of Medical Education", Vol.32, Aug. 1957, blz. 557-563.

DROGENDIJK,A.C.: "Huisarts en geneeskunde in verleden, heden en toekomst" Haarlem, 1965, blz. 23 en $v \mathrm{Lg}$. EBERT,R.H. : "Medical Education at the University". In:

"Views of Medical Education and Medical Care". Edited by J.H.KNOWLES. Cambridge, 1968, blz. 117 en vlg.

ENDE,W.J. (VAN DEN), MERENS-RIEDSTRA,A.S. : "Onderlinge relaties tussen de artsen die betrokken zijn bij de behandeling van hartinfarctpatiënten". Lejden, 1972. 
FIELO, G. : "Structured strain in the role of the soviet Physician". In: "The American Journal of sociology", Vol.38, $n^{\circ} .5$, March 1953, blz. 493-502.

FIELD, M. : "Patients and People. A medical-social approach to prolonged illiness". New York and London, 1967, bLz. 15. FOX,c.: "Training for uncertainty". In : "The Student-Physician". Introductory studies in the sociology of medical ecucation. Uitgegeven door R.K.MERTON, G.READER and P.L.KENDALL. Cambridge, 1957, blz. 207-241.

FREEMAN,H.E., LEVIN, S. REEDER,L.G.: "Handbook of Medical Sociology". New York, 1963, blz. 306.

GRAAF, A.C.CDE) en PHILIPSEN,H. : "Berichtgeving over lichamelijke en geestelijke gezondheid in yijf landelijke ochtendbladen". In: "Tijdschrift voor sociale Geneeskunde", n".45, $1976, b(z, 722-732$. GOOR, I.A.(VAN): "Huisarts en preventieve gezondheidszorg". Assen, 1961, blz. 43. HAESAERT, J. : "Essai de sociologie". Les Editions Lumière, s.d., Gent, Blz. 114. HAMMOND, K.F., KERN,Fr. : "Teaching comprehensive medical care: a pychological study of a change in medical education". Cambridge, $1959, b ! z .157$.

HOFF,F.: "Bestand und wandel in Artzlichen Denker". In:

"Hippokrates", 25 Jahrgang, 31 August 1954, Heft 16, blz. 496.

JANSSENS, H. : "Arts en Patiënt" IV.In:"De Standaard", 1 mei 1964. JOHNSON,W.M. : "The training of the general practitioner".

In : "Canadian Medical Assaciation Journal", Vol.62, 1950, $n^{0} .1, b l z .9$.

LAMBERTS,H: : "Samenwerken in een team. Een routebeschrijuing door een ruig landschap". In: "Huisarts en wetenschap", $n^{0} .17,1974, b(2,15-23$.

LAMMERS,C.J.: "De huisarts en zijn patiënt. Een sociologische voorstudie". Sociaal Wetenschappelijke Verkenningen, 1957. ISONEWO. 
LARSEN,D.E.; ROOTMAN, I. : "Physicians role performance and patient satisfaction". In : "Social science and Medicine", Vol.10, $n^{\circ} .1$, Jan. 1976, blz. 29-32.

LEDERER,H.D. : "How the sick view their wortd". In: "The Journal of Social Issues", Vol.8, 1952, blz. 254-255.

MACGREGOR, F.C. : "Some psychological hazards of plactic surgery of the face". In APPLE,D. : "Sociological studies of Health and Sickness". London, 1960, blz. 145-153. MELKER,R.A. (DE) : "Ziekenhuispatient, huisarts, huisgezin".

Nijmegen, 1973.

MENZEL,H., COLEMAN,J., KATZ,E. : "Dimensions of being Modern" in Medical Practice". In : "Journal of Chronic Diseases", Vol.9, n०.1, Jan. 1959, blz. 34 en vlg. NEUFFER, H. : "Gedanken über den Artz un unseren Zeit". In: "Artzliche Mitteillungen", 43 Jahrgang, Heft 15, 12 april $1958, b l z .379-380$.

NUYENS, Y. :Grenzen aan de medische macht". Horizonreeks, $n^{\circ} .31$, Leuven, 1976, blz. 52. PERSOON,J.M.G. : "Veranderingen in de patient-huisartsenrelam tie". 1972 .

PETERS,W. : "Der Artz in unseren zeit". In: "Artzliche Mitteillungen", 41 Jahrgang, Heft 12, 21 April 1956, bl.z. 327. PHILIPSEN,H. : "De omvang en complexiteit van algemene ziekerhuizen". In : "De gewone ervaring leert al anders".

Afscheidsbundel ter nagedachtenis a an Prof. A.N.J. den Hollander. Alphen aan den Rijn, 1976, blz. 152-171. QUERIDO, A. : "Inleiding tot de integrale geneeskunde". Leiden, 1955.

QUERIDO,A. : "Voordrachten over sociale geneeskunde". 1958. QUERIDO,A. : "Geneeskunst in transcendentie". In: "Werken in uitvoering. Een keur wit de geschriften van Prof.A. Querido". Amsterdam, 1970.

REDLICH,F.C.: "Der Gesundheitsbegriff in der Psychiatrie". In : "Der Kranke in der modernen Gesellschaft" (A.MITSCHERLICH e.a. Herausgeber) 1973. 
ROBINSON,G.C.: "The patient as a person. A study of the social aspects of illness". New York, 1939, blz. 408. ROMANO,J.: "Requien or Reveille. The Clinician's Choice". Presented at the 73rd Annual Meeting of the Association of American Medical Colleges. Los Angeles, Oct. 301962 (overgenomen met toestemming van de uitgever). ROSKAM,Edw.E.: "A documentation of MINISSA-I (N)". Report 75 MA 15 alias Program Bulletin, nr.12 (rev.ed.), August 1975, Department of Psychology, Kathalieke Universiteit, Nijmegen, $33+8 \mathrm{p}$.

SIGERIST,H.E. : "Introduction à la médecine". Paris, 1932, $b l z .133$.

SOUDIJN,K.A. "Kennisproblemen bij psychotherapieën". In: Kennis en Methode", Jg.1, 1977, n.1, blz.21-36. STEINEBACH,Dr.: "Artzliche Autgaben Gestern und Heute". In: "Artzliche Mitteillungen", Vol.41, Heft 12, 21 April 1956, $b L z .330$.

SWARTE, J.H. "Diskriminatie van geesteszieken". In : "Maandblad voor de geestelijke volksgezondheid", $n^{0} .23,1968, b l z$. $421-426$.

THEIL,P. : "Pour le meilleur oli le pire? L'information médicale du 'grand public ". In ECK,M. : "Le médecin face aux risques et a la responsabilite". (Textes réunis...) paris, 1958.

WEIJEL,J.A. "Medische psychologie". Utrecht, 1961. WERKGROEP Alternatieve Economie: "Dure Geneeskunde? - Economische Aspecten van de Gezondheidszorg in België" "Leuven. 1975 .

WILSON,6. : "The disadvantages and limitations of clinic or graup medicine". In : "The Journal of the American Medical Association", June 24, Vol.78, n०.25, blz. 1922. ZWEERS-WIERSMA,A.C.: "Huisarts en geestelijke gezondheid". Boom-Meppel, 1968, blz.84. 